UNIVERSIDADE DE SÃO PAULO

FACULDADE DE FILOSOFIA, LETRAS E CIÊNCIAS HUMANAS

DEPARTAMENTO DE HISTÓRIA

PROGRAMA DE PÓS-GRADUAÇÃO EM HISTÓRIA SOCIAL

EDSON PEDRO DA SILVA

\title{
THE BIG EVENT
}

\section{HISTÓRIA, MEMÓRIA E IDENTIDADE}

NA MINISSÉRIE "HOLOCAUSTO"

VERSÃO CORRIGIDA

SÃO PAULO

2015 
UNIVERSIDADE DE SÃO PAULO

FACULDADE DE FILOSOFIA, LETRAS E CIÊNCIAS HUMANAS DEPARTAMENTO DE HISTÓRIA

PROGRAMA DE PÓS-GRADUAÇÃO EM HISTÓRIA SOCIAL

EDSON PEDRO DA SILVA

\title{
THE BIG EVENT
}

\section{HISTÓRIA, MEMÓRIA E IDENTIDADE NA MINISSÉRIE "HOLOCAUSTO”}

\author{
Dissertação apresentada ao Programa de Pós- \\ Graduação em História Social da Universidade de \\ São Paulo como requisito parcial para a obtenção \\ do título de Mestre em História. \\ Orientador: Prof. Dr. Jose Antonio Vasconcelos \\ VERSÃO CORRIGIDA
}

SÃO PAULO

2015 
SILVA, Edson Pedro da. The Big Event: História, memória e identidade na minissérie "Holocausto". Dissertação apresentada à Faculdade de Filosofia, Letras e Ciências Humanas da Universidade de São Paulo para a obtenção de título de Mestre em História Social.

Aprovado em:

Banca Examinadora

Prof. Dr. Instituição:

Julgamento: Assinatura:

Prof. Dr. Instituição:

Julgamento: Assinatura:

Prof. Dr. Instituição: Julgamento: Assinatura: 
Resumo

A presente investigação tem como objetivo estabelecer uma reflexão sobre as relações entre a história e a memória por meio da análise da minissérie "Holocausto" (1978), produção televisiva veiculada pela rede norte-americana NBC. O enredo de "Holocausto" está centrado na trágica narrativa sobre uma família judia-alemã no período que vai de 1935 a 1945. Modelo típico de judeus assimilados na Berlim dos primeiros anos do nazismo, a família Weiss testemunha as trágicas mudanças em sua realidade com a ascensão do nazismo e o estabelecimento do antissemitismo como política de estado. A minissérie é apontada como um marco na emergência do interesse sobre o Holocausto na consciência pública norte-americana, apresentando um discurso narrativo a respeito do extermínio dos judeus europeus que está diretamente vinculado à valorização desta mesma memória pela comunidade judaica. Pretende-se apontar que o aspecto comemorativo dessa produção audiovisual e o impacto verificado em sua exibição fora dos Estados Unidos, sobretudo na República Federal Alemã, evidenciam a complexidade da relação entre a história e os discursos de memória.

PALAVRAS-CHAVE: Holocausto, Nazismo, Identidade judaica, Memória, Televisão, 


\begin{abstract}
This investigation's purpose is to establish a reflection about the relations between history and memory through the analysis of the miniseries "Holocaust" (1978), production broadcasted by the North American television channel NBC. The plot of "Holocaust" focuses on the tragic narrative of a Jewish-German family in the period from 1935 to 1945. A typical example of assimilated Jews, the Weiss family witnesses the tragic changes in their lives with the rise of Nazism and the establishment of antiSemitism as a state policy. The miniseries is considered a landmark in the emergence of interest about the Holocaust in the public conscience of American people, presenting a narrative concerning the extermination of European Jews that is directly linked to the appreciation of this memory by the Jewish community. We intend to point that the commemorative aspect of this audio-visual production and the impact shown by its exhibition outside the United States, mainly in the Federal Republic of Germany, evidence the complexity of the relation between history and the memory discourse.
\end{abstract}

KEYWORDS: Holocaust, Nazism, Jewish identity, Memory, Television. 


\section{AGRADECIMENTOS}

Gostaria de agradecer inicialmente ao professor José Antonio Vasconcelos pela abertura e disponibilidade para a orientação deste trabalho. Seu apoio desde o início, sua paciência e valiosas observações sobre os rumos desta pesquisa foram fundamentais neste percurso de mais de três anos. Meus momentos de angústias e dúvidas, naturais a quem ingressa no mestrado, sempre encontraram a segurança de suas sugestões, avaliações e correções. Deixo aqui minha admiração e profunda gratidão.

Agradeço ao professor Eduardo Morettin que, dada a natureza interdisciplinar desta pesquisa, contribuiu enormemente para a definição dos rumos da dissertação aqui apresentada. Suas sugestões e indicações de leitura e os comentários compartilhados na disciplina "Cinema, Memória e História: Formas de Representação Audiovisual" permitiram evidentes avanços nesta investigação.

Aos professores Maurício Cardoso e Maria Luiza Tucci Carneiro, pelas valiosas contribuições apresentadas em minha qualificação. Ao professor Allan Megill, não só pela contribuição pessoal no breve encontro que tivemos, mas também pelas valiosas reflexões nos textos utilizados nesta investigação.

Aos queridos amigos da graduação e agora do mestrado: Natália Frizzo, Ricardo Streich, Danilo Barolo, Tais Araújo, André Ponce e Robson Bello. Nossas longas e estimulantes conversas, em várias ocasiões, resultaram em reflexões indispensáveis durante esta pesquisa. Quero reafirmar aqui que os tenho como amigos para toda a vida.

À bibliotecária Charlotte Bonelli, responsável pela biblioteca e arquivo do American Jewish Committee, em Nova York, que me recebeu tão carinhosamente e me disponibilizou documentos imprescindíveis para o andamento deste trabalho em minha viagem de pesquisa. Aos bibliotecários da Library of Congress e do United States Holocaust Memorial Museum em Washington DC pela disponibilização de valiosas coleções e recursos. Aos funcionários da coleção audiovisual do Paley Center for Media, também em Nova York, por toda a assistência oferecida.

Ao Raoni, companheiro da vida e também revisor deste texto final. Seu total apoio e compreensão foram imprescindíveis nesta caminhada. 
À minha mãe e meus irmãos, que em vários momentos de nossa vida familiar abriram mão de seu tempo e recursos para que eu, o filho caçula, pudesse chegar até aqui. Sua preocupação, atenção e palavras de estímulo são o combustível que me move na direção das coisas que acredito. Sem este apoio da família nada disso seria possível. 


\section{SUMÁRIO}

Introdução. 9

Capítulo 1 - O Holocausto e a representação audiovisual .19

1.1 - O olhar do cinema para a tragédia judaica................................................20

1.2 - O Holocausto na televisão norte-americana..............................................24

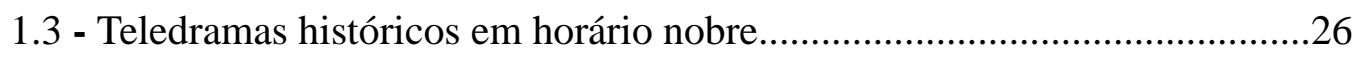

Capítulo 2 - "Holocausto - a história da família Weiss" .35

2.1 - A mobilização da audiência........................................................................ 35

2.2 - Primeiro episódio: “The Gathering Darkness”..........................................42

2.3 - Segundo episódio: “The Road to Babi Yar”...............................................70

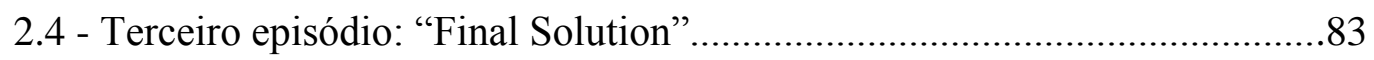

2.5 - Quarto episódio: “The Saving Remnant”...............................................102

Capítulo 3 - “Holocausto" e os limites da representação.......................................117

3.1 - As reações do público: perguntas e respostas..........................................117

3.2 - Televisão como banalização: memória e ultraje......................................121

3.3 - Televisão, memória e passado reprimido: polêmicas de uma exportação

Capítulo 4 - "Holocausto" entre a História, a memória e a comemoração.............134

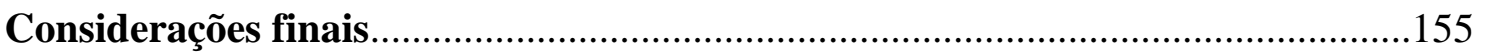

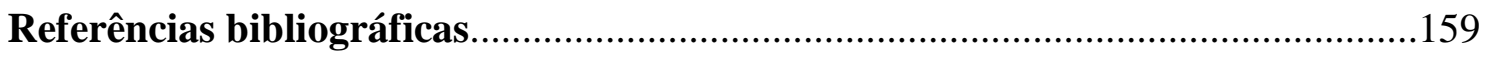

Filmografia 


\section{INTRODUÇÃO}

Nas últimas décadas as discussões teóricas e pesquisas acadêmicas envolvendo os vínculos entre a memória e a história entraram em franca evidência. Embora longe de esgotar as diferentes abordagens sobre o tema, a emergência dessa valorização tem como pressuposto uma preocupação mais intensa em conceituar, definir limites e estabelecer hierarquias entre estas duas áreas, quando não revelar a impossibilidade de sua dissociação. Diversos fatores estão na origem do aumento dessa discussão, diretamente relacionada com o que se convencionou chamar, nos últimos trinta anos, de "memory boom". A crise dos paradigmas das ciências humanas, os novos objetos da historiografia, as reflexões a respeito do estatuto científico da disciplina histórica e a valorização da história oral e do testemunho como objeto de investigação histórica, podem ser apontados como alguns desses fatores ${ }^{1}$.

No que diz respeito a esse último aspecto há um traço essencial na origem das discussões teóricas envolvendo a questão da memória e de sua relação com a história. Trata-se da referência a lembranças de eventos históricos traumáticos, quase sempre relacionadas com memórias de guerras, massacres e ditaduras, recuperadas em um momento histórico posterior, em muitos casos sob o peso de um ambiente de acerto de contas com o passado. O nazismo e o Holocausto, os crimes do comunismo soviético, as ditaduras militares na América Latina e o Apartheid na África do Sul são alguns dos exemplos de situações históricas cuja rememoração pavimentou o caminho dos debates teóricos envolvendo as questões da memória e do esquecimento e de sua relação com a disciplina histórica. Em sua obra clássica "A memória, a história, o esquecimento", em que delineia uma fenomenologia da memória, o filósofo Paul Ricoeur faz menção à problemática da memória de fatos históricos traumáticos, explicitando uma preocupação a respeito das conexões entre a memória e a história:

perturba-me o inquietante espetáculo que apresentam o excesso de memória aqui, o excesso de esquecimento acolá, sem falar da influência das comemorações e dos erros de memória - e de esquecimento. A ideia de uma política da justa memória é, sob esse aspecto, um de meus temas cívicos confessos. $^{2}$

\footnotetext{
${ }^{1}$ Para um panorama dos desafios envolvendo o campo de estudo da memória social ver OLICK, Jeffrey K., JOYCE, Robins. Social memory studies: from "collective memory" to the historical sociology of mnemonic practices. Annual review of sociology. Vol. 24 (1998), pp 105-140.

${ }^{2}$ RICOEUR, Paul. A memória, a história, o esquecimento. Campinas: Editora da Unicamp, 2007 p. 17.
} 
Esta preocupação com uma política da justa memória mencionada por Ricoeur passa necessariamente por um aprofundamento das discussões que envolvem sua relação com a história pois estes dois âmbitos frequentemente se confundem gerando intensos debates. Tais debates apresentam, de maneira geral, pontos de vista conflitantes. De um lado existe uma busca pela delimitação entre os dois campos, subordinando a memória à história ou estabelecendo uma oposição entre ambos. Nessa perspectiva considera-se que a função da história é corrigir a excessiva preocupação com a memória e o seu caráter de subjetividade ${ }^{3}$. A maioria das proposições mais próximas a esta concepção recuperam o conceito de memória coletiva, aprofundado pelo clássico estudo do sociólogo Maurice Halbwachs. O próprio Halbwachs chega a refutar a noção de uma "memória histórica", por associar dois termos opostos. "Em geral a história só começa no ponto em que termina a tradição, momento em que se apaga ou se decompõe a memória social"4.

Outros autores, como o historiador americano Allan Megill, também enfatizam a proeminência da história em relação à memória, embora atuando de maneira crítica em relação a alguns aspectos dos postulados de Maurice Halbwachs. A própria memória histórica, ou seja, os modos de lembrar o passado, nesse ponto de vista, poderia ser um objeto legítimo de investigação do historiador. Ainda segundo Megill:

É um erro ver a memória e a história como continuação um do outro: também é errado, por exemplo, pensar a memória como a matéria-prima da História. É igualmente um erro pensar que a história é simplesmente a soma de todas as lembranças possíveis (...). Mas é igualmente um erro ver a história e memória como simplesmente opostos. Por um lado, longe de ser matéria-prima da história, a memória é um Outro que assombra a História. A memória é uma imagem do passado construído por uma subjetividade no presente. ${ }^{5}$

Megill aponta que, para Maurice Halbwachs, as identidades sociais existem antes de suas próprias memórias coletivas, que são construídas por elas. Nesse sentido, a identidade precede a memória. Na contemporaneidade, no entanto, vivenciamos uma

\footnotetext{
${ }^{3}$ MEGILL, Allan. Historical knowledge, historical error. Chicaco: Chicago University Press, 2007, p. 22 (Trad. do autor). No original: "It is a mistake to see memory and history as continuous with each other: a mistake, for example, to think of memory as the raw material of history. It is likewise a mistake to think that history is simply the sum of all possible memories (...). But is equally a mistake to see history and memory as simply opposed to each other. On the one hand, far from being history's raw material, memory is an Other that continually haunts history. Memory is an image of the past constructed by a subjectivity in the present."

${ }^{4}$ HALBWACHS, Maurice. A memória coletiva. São Paulo: Centauro, p. 101.

${ }^{5}$ MEGILL, Allan. op. cit., p. 57.
} 
dificuldade de fixar identidades, o que explica o esforço de construções de discursos de memória com o objetivo de restabelecer estas mesmas identidades fragmentadas ${ }^{6}$. Megill sugere que o conceito de comunidades imaginadas - apresentado pelo historiador Benedict Anderson em sua obra clássica sobre a ascensão do sentimento nacional - é um caminho mais apropriado de reflexão do que o modelo proposto por Halbwachs. Segundo Anderson, quanto mais uma comunidade é "imaginada", maior a sua necessidade de ancorar-se na memória ou no esquecimento. Em relação à formação dessas comunidades no contexto do nacionalismo, ele afirma:

a biografia da nação agarra, à revelia dos índices de mortalidade, aqueles suicídios exemplares, os martírios dolorosos, os assassinatos, as execuções, as guerras e os holocaustos. Mas, para servir à finalidade narrativa, essas mortes violentas precisam ser lembradas/esquecidas como "nossas" mortes. ${ }^{7}$

Embora seu estudo esteja mais centrado na questão da formação dos estados nacionais, as afirmações de Benedict Anderson oferecem uma indispensável contribuição às reflexões sobre comunidades que não se referem diretamente de um estado nacional, mas a identidades étnicas, religiosas ou culturais que já compõem o quadro social heterogêneo de nações já estabelecidas. Alguns exemplos dessa natureza podem ser facilmente encontrados no caso de comunidades de imigrantes europeus na América ou na ação afirmativa de alguns grupos étnicos dos diversos países do mundo. No caso específico desta investigação, o objeto de análise se refere às relações da comunidade judaica norte-americana com a memória do Holocausto, o maior evento traumático de sua história na modernidade.

No campo dos estudos da memória social é comum estabelecer uma relação entre o aumento do interesse por esta área na contemporaneidade e o evento histórico do Holocausto. Segundo o antropólogo britânico Paul Connerton, a valorização da memória nas últimas décadas está fortemente conectada com a repercussão desse evento $^{8}$. Há de fato alguns aspectos da natureza do Holocausto que ajudam a explicar a intensidade e o interesse pela memória social de um modo geral e pelos estudos de

\footnotetext{
${ }^{6}$ Pierre Nora aprofundou esta reflexão em seu ensaio sobre os lugares de memória. NORA, P. Entre memória e história: a problemática dos lugares. Tradução de Yara Aun Khoury. Revista do Programa de Estudos Pós-Graduados em História e do Departamento de História da PUC-SP. (Projeto História: História e Cultura). São Paulo, n.10, dez.1993.

7 ANDERSON, Benedict. Comunidades Imaginadas: reflexões sobre a origem e a difusão do nacionalismo. São Paulo: Companhia da Letras, 2008, p. 280.

${ }^{8}$ CONNERTON, Paul. How societies remember. Cambridge: Cambridge University Press, 1989 APUD LEVY, Daniel, OLICK, Jeffrey K.,VINITZKY-SEROUSSI, Vered. The Collective memory reader. Oxford University Press, 2011, p. 29.
} 
memória nas investigações acadêmicas. De um ponto de vista mais amplo, a percepção do Holocausto e do nazismo como símbolos do mal absoluto, o próprio esforço de registro audiovisual dos testemunhos de sobreviventes e a construção de museus e monumentos em memória às vítimas do genocídio nazista reforçam esta inegável conexão entre este evento histórico e o chamado "memory boom". Deve-se levar em conta, no entanto, que outros aspectos como a própria escala dos crimes cometidos, a imagem simbólica das vítimas de Auschwitz como um paradigma da barbárie e da crise da modernidade e a questão controversa do retorno de uma memória traumática reprimida também justificam essa aproximação ${ }^{9}$. O teórico da literatura Andreas Huyssen afirma que a emergência do Holocausto como um tropo universal permitiu que a memória sobre o genocídio funcionasse como um paradigma para situações políticas e eventos históricos distantes, resultando em uma espécie de memória globalizada ${ }^{10}$.

A mediação audiovisual cumpre um papel fundamental em relação à memória do Holocausto, tanto pela importância do registro fílmico e iconográfico de uma das maiores catástrofes da humanidade quando por seu caráter paradigmático em relação aos próprios limites da representação deste evento. Deve-se destacar aqui que não só a mídia audiovisual cumpre um papel preponderante em relação à transmissão da memória social, em um sentido mais amplo. O historiador Peter Burke nos lembra que "memórias são afetadas pela organização social de diferentes tipos de mídias empregadas em sua transmissão"11.

Recuperarmos as relações entre a história, a memória e o discurso audiovisual, um campo de investigação relativamente recente para o historiador, é fundamental para compreendermos de que maneira os discursos de memória são transmitidos e perpetuados pelo objeto fílmico. O desafio inerente à análise de fontes audiovisuais está em seu estatuto intermediário entre uma percepção objetivista (que considera tais fontes a partir de uma perspectiva estritamente documental como um testemunho realista do passado) e uma percepção subjetivista (relacionada ao caráter artístico do documento

\footnotetext{
${ }^{9}$ LEVY, Daniel, OLICK, Jeffrey K. VINITZKY-SEROUSSI, Vered. The collective memory reader. Oxford University Press, 2011, p. 30-31.

${ }^{10}$ HUYSSEN, Andreas. Present pasts: media, politics, amnesia. Public Culture, Durham: Duke University Press, v.12, n. 1, p. 24.

${ }^{11}$ BURKE, Peter. From history as social memory. In: LEVY, Daniel, OLICK, Jeffrey K., VINITZKYSEROUSSI, Vered. The Collective memory reader. Oxford University Press, 2011, p. 189. No original: "Memories are affected by the social organization of transmission and the diferente media employed."
} 
estético que representa o passado, quase sempre através de uma narrativa ficcional) ${ }^{12}$. Há, neste sentido, uma tensão entre esses dois polos. Em relação ao Holocausto, tal tensão surge de maneira inequívoca na frequente defesa dos documentários que abordam este evento histórico (no qual o filme "Shoah", de Claude Lanzmann, é o exemplo geralmente mencionado) em detrimento das representações ficcionais que frequentemente são acusadas de banalizar, explorar ou atrever-se a uma representação melodramática de um evento considerado "nos limites" (caso da minissérie "Holocausto" que é o objeto desta análise).

É inegável que grande parte do imaginário histórico presente no senso comum a respeito do Holocausto foi e continua sendo forjado pela encenação do passado por meio do cinema e da televisão. A interdição ética da representação fílmica do Holocausto remete à clássica afirmação do filósofo da Escola de Frankfurt, Theodor Adorno, postulando que escrever poesia depois de Auschwitz é um ato de barbárie ${ }^{13}$. A afirmação de Adorno faz referência à representação de um evento que "supera as possibilidades e os limites da representação"14. Apesar das variadas interpretações para essa afirmação, há um consenso de que seu objetivo foi apontar algumas exigências para a arte após o Holocausto. A primeira delas é um esforço contra o esquecimento desse evento e de seu significado. A segunda é uma luta para que a memória deste evento não se torne um produto mercantilizado e transformado em mero espetáculo. Nas palavras de Jeanne Marie Gagnebin, "Desenha-se, assim, uma tarefa paradoxal de transmissão e de reconhecimento da irrepresentabilidade daquilo que, justamente, há de ser transmitido porque não pode ser esquecido"15.

A despeito de uma alegada impossibilidade ou interdição para a representação audiovisual, o Holocausto continuou sendo um tema central de uma série de produções cinematográficas e televisivas nas últimas décadas. Alguns desses filmes serão apresentadas neste trabalho no intuito de evidenciar uma correlação entre essas produções e a emergência desta memória nos Estados Unidos. Tais produções tornaram-

\footnotetext{
${ }^{12}$ NAPOLITANO, Marcos. Fontes audiovisuais: a história depois do papel. In: PINSKY, Carla (Org). Fontes históricas. São Paulo: Contexto, 2005. p. 237.

${ }^{13}$ FRIEDLÄNDER, Saul (Org.) Probing the limits of representation: Auschwitz and the Final Solution, Harvard: Harvard University Press, 1992, p. 2.

${ }^{14}$ ROSENSTONE, Robert. A. A história nos filmes, os filmes na história. São Paulo: Paz e Terra, 201, p. 198.

${ }^{15}$ GAGNEBIN. Jeanne Marie. Após Auschwitz. In: SELIGMAN-SILVA, Márcio (Org.) História, Memória, Literatura: O testemunho na Era da Catástrofes. Campinas: Editora da Unicamp, 2003, p. 108.
} 
se mais frequentes a partir da década de 70, tendo a própria minissérie se estabelecido como um dos catalisadores desta mudança, ao lado do documentário "Shoah" (1985) e, anos mais tarde, do filme "A Lista de Schindler" (1994), do diretor Steven Spielberg. O aumento dessas produções cinematográficas obviamente se explica pela valorização dessa memória no mesmo período e aponta para a importância da mediação audiovisual neste processo. Em relação às produções cinematográficas há uma intensa e atuante produção intelectual resultante dos debates sobre a representação fílmica do Holocausto, sua história e implicações éticas, estéticas e políticas. Verificamos no entanto que, no que diz respeito às produções televisivas, há uma evidente escassez de estudos que avaliam o papel da mídia televisiva na transmissão e no estabelecimento dos discursos de memória, notadamente em relação à memória do Holocausto.

O meio televisivo desempenha nos dias atuais um papel fundamental no tocante à percepção que a maioria das pessoas constrói a respeito do passado. O primeiro encontro do público com o conhecimento histórico se dá, em muitos casos, por meio das representações históricas exibidas pela televisão, seja em documentários, telenovelas de época ou séries dramáticas televisivas de fundo histórico. Aparelho doméstico por natureza, a televisão se configura muitas vezes como um primeiro veículo desse contato, sedimentando percepções e imaginários sobre a experiência histórica que poderão ou não ser modificados no futuro. Tal contato não se dá apenas em relação à representação presente em reconstruções da teledramaturgia sobre eventos ou personagens históricos como também na própria ideia da televisão como um facilitador do testemunho visual de grandes acontecimentos noticiosos, recuperados posteriormente por meio da memória coletiva ou da investigação historiográfica. $\mathrm{O}$ especialista em estudos de mídia, Gary R. Edgerton, na introdução de uma coletânea de textos que analisam o papel da televisão no estabelecimento da memória coletiva, aponta que suas representações fictícias e não-fictícias “alteraram (...) o modo como dezenas de milhares de espectadores pensam sobre eventos e figuras históricas" 16 .

Com base nas observações apontadas acima, definimos a minissérie "Holocausto", drama televisivo produzido em 1978, como objeto de análise desta investigação, por se tratar de um produto cultural diretamente vinculado com a

\footnotetext{
${ }^{16}$ EDGERTON, Gary. R. COLLINS, Peter C. (Org). Television histories: shapping collective memory in the media age. Kentucky University Press, 2001, p. 1. (Trad. do autor). No original: "altered (...) the way tens of millions of viewers think about historical figures and events."
} 
emergência da memória deste evento histórico nos Estados Unidos. As indagações a respeito da valorização desta memória que despertaram o interesse por esta investigação nos levaram a este produto da indústria cultural cujo significado e impacto ultrapassaram os objetivos iniciais de sua produção. Se este teledrama é frequentemente apontado como um marco da valorização do Holocausto no imaginário cultural norteamericano, ele também possibilitou o início de um processo de globalização e "americanização" da memória audiovisual da shoah ${ }^{17}$ que tem os Estados Unidos como principal protagonista ${ }^{18}$. Como veículo de transmissão de um determinado discurso de memória, "Holocausto" se destaca por apresentar uma narrativa ficcional como pano de fundo histórico, apoiando-se nos principais eventos do genocídio judaico para criar uma conexão entre este evento histórico e a comunidade judaica norte-americana.

As narrativas históricas televisivas demonstram a inserção da televisão no modelo do cinema industrial. No intuito de reforçar discursos de memória, estas narrativas mantêm a prerrogativa do naturalismo cinematográfico e da forma dramática como elementos essenciais de seus formatos. No caso da televisão é indispensável apontar que as construções históricas televisivas realçam "uma dicotomia entre o bem e o mal definida pedagogicamente na construção da narrativa, sujeita, assim, a uma forte polarização entre seus personagens e seu conteúdo"19. Tal abordagem pedagógica exerce, por meio de seu conteúdo histórico, um papel preponderante na formação de identidades, sobretudo ligadas à memória nacional. No que tange à representação histórica, a minissérie "Holocausto" também mantém as estratégias de autenticação do discurso cinematográfico "empregadas pelo cinema para validar a representação de um tema" ${ }^{20}$. Desta forma, a presença de figuras históricas em meio a personagens ficcionais e filmes e fotos de arquivo que documentaram os eventos retratados buscam validar o discurso histórico sobre esses mesmos eventos. Considerando a narrativa ficcional do teledrama como mecanismo de atração da audiência e a emergência de discursos negacionistas a respeito do Holocausto que procuraram explorar tal aspecto, estas estratégias de autenticação ganham ainda maior relevância.

\footnotetext{
${ }^{17} \mathrm{O}$ vocábulo hebraico shoah significa catástrofe e em geral é o termo utilizado pela comunidade judaica para se referir ao evento histórico do Holocausto.

${ }^{18}$ SÁNCHEZ-BIOSCA, Vicente. Cine de história, cine de memória: la representación y sus limites. Madrid: Ediciones Cátedra, p. 156.

${ }^{19}$ KORNIS, Mônica de Almeida. Cinema, televisão e história. Rio de Janeiro: Zahar, p. 51.

${ }^{20}$ MORETTIN, Eduardo. Ver o que aconteceu: cinema e história em Griffith e Spielberg. Revista Galáxia, São Paulo, n. 22, dez. 2011, p. 196.
} 
A proposta apresentada aqui, pensada a partir da questão da memória do Holocausto transmitida pela representação audiovisual, é sugerir que as dicotomias entre uma possível "memória justa" como contraponto ao uso político de afirmação de identidade, à banalização ou à mercantilização da memória traumática de um dos mais catastróficos eventos do século XX não permitem avançar para uma reflexão mais enriquecedora do ponto de vista das relações entre a memória e a história. Entendemos que a análise de um documento audiovisual como "Holocausto" nos permite levantar algumas questões importantes para o debate sobre as intenções dos discursos de memória, suas relações com as afirmações de identidade e um caminho de reflexão de duas vias que se estabelece nas relações entre a história e a memória.

O primeiro capítulo deste trabalho tem como objetivo apresentar os aspectos mais gerais da representação audiovisual do Holocausto. Esta abordagem inicial procurará apontar a natureza documental das primeiras produções cinematográficas, ainda imbuídas de um estilo nutrido pela proximidade temporal dos eventos retratados, passando em seguida para a exploração do tema pelo cinema hollywoodiano e suas relações com o protagonismo da comunidade judaica em relação a este evento. $\mathrm{Na}$ sequência será analisada a questão da representação do Holocausto na televisão, um veículo de mediação cujo processo de formação entre o público telespectador é contemporâneo à própria memória do Holocausto. Uma avaliação sobre o surgimento das minisséries com temas históricos (entre as quais se destaca o pioneirismo de "Raízes" em 1977) e sua ligação com temas de valorização étnica nos permite compreender a natureza deste formato e a decisão que levou à posterior produção de "Holocausto" a partir do mesmo modelo. Uma série de documentos de divulgação foi utilizada no esforço de divulgação empreendido pelos produtores do teledrama e alguns deles serão apresentados neste capítulo.

No intuito de compreender o significado do documento audiovisual que é objeto desta pesquisa, procurou-se examiná-lo a partir de sua própria lógica interna, seu enredo, personagens e suas representações. De acordo com as proposições do pesquisador das relações entre a história e o cinema, Eduardo Morettin, "para que possamos recuperar o significado de uma obra cinematográfica, as questões que 
presidem o seu exame devem emergir de sua própria análise"21 . A partir dessa premissa, o segundo capítulo procura explorar a concepção da minissérie "Holocausto" e sua própria narrativa por meio da análise de cada um de seus consecutivos episódios. Há um cotejamento entre os eventos históricos retratados e o relato historiográfico sobre os mesmos eventos para que se estabeleça o diálogo entre a escolha narrativa do que está sendo representado e o significado que tal representação procura reforçar no discurso de memória pretendido pelo teledrama. É importante destacar que o documento físico para a análise desta fonte audiovisual foi feito a partir do DVD lançado em 2012. Evidentemente que uma análise a partir da versão original, tal como exibida aos telespectadores em 1978, poderia resultar em uma maior riqueza analítica. Tive acesso à exibição neste formato por apenas algumas horas em uma visita ao The Paley Center for Media, em Nova York, instituição que possibilita ao pesquisador assistir às obras televisivas tal como foram veiculadas. Este acesso foi importante na verificação dos intervalos comerciais frequentemente apontados pelos críticos como um dos maiores problemas de "Holocausto". A análise do DVD levou em consideração a disposição narrativa dos episódios tal qual a veiculação original.

Naturalmente que o estabelecimento da minissérie como um marco da memória social norte-americana e mundial sobre o Holocausto torna necessário apresentar de que forma se deu sua repercussão, tanto em seu país de origem como nos vários países para os quais o teledrama foi exportado. A natureza distinta da recepção da minissérie em diferentes contextos e os debates e polêmicas que despertou serão analisados no terceiro capítulo. Cabe aqui destacar a problemática metodológica inerente aos estudos de recepção de um produto cultural televisivo como "Holocausto". A historiadora do cinema Miriam Hansen, em uma referência a respeito do impacto do filme "A Lista de Schindler" na Alemanha (frequentemente comparado com o impacto produzido por "Holocausto"), destaca esta dificuldade ao afirmar que uma abordagem a respeito da recepção "requer uma abordagem que seja capaz de mediar resultados empíricos e níveis teóricos de argumentação" 22 . Neste sentido procuramos destacar com maior ênfase o debate público e as críticas da imprensa e do meio intelectual que nos

\footnotetext{
${ }^{21}$ MORETTIN, Eduardo. O Cinema como fonte histórica na obra de Marc Ferro. In CAPELATO, Maria Helena (Org.). História e cinema. São Paulo: Alameda, 2007, p. 63.

${ }^{22}$ HANSEN, Miriam. Schindler's List is not Shoah: the second commandment, popular modernism and public memory. Critical Inquiry, Chicago: Chicago University Press, vol. 22, n. 2, 1996, p. 295. (Trad. do autor). No original: "requires an approach that is capable of mediating empirical and theoretical levels of argument."
} 
permitiriam aproximar os resultados pretendidos pela minissérie de sua real apropriação por parte do público geral e especializado.

Finalizando a análise, o quarto e último capítulo procurará relacionar as intenções discursivas da minissérie com a valorização da memória do Holocausto nos Estados Unidos e a consequente crítica historiográfica sobre essa valorização. Neste tópico mais teórico as discussões propostas no início desta introdução serão aprofundadas, destacando novamente as relações entre a memória e a história, apresentando e reforçando suas delimitações e finalmente sugerindo uma reflexão que leve em conta as nuances dos discursos audiovisuais de memória para o conhecimento histórico. 


\section{CAPÍTULO 1 - O Holocausto e a representação audiovisual}

As primeiras produções cinematográficas a apresentarem o Holocausto como tema na Europa e nos Estados Unidos foram realizadas a partir de uma concepção que o historiador Vicente Sanchez-Biosca chamou de "pedagogia do horror"23. Tais produções, ainda muito próximas às imagens produzidas pelos exércitos aliados na liberação dos campos de concentração e extermínio, tinham uma clara estética documental, tendo algumas delas sido filmadas nos próprios campos onde se passaram suas representações fílmicas de narrativa ficcional. Os filmes sobre a liberação dos prisioneiros na Alemanha e na Polônia produzidos pelos exércitos americano, britânico e soviético foram as primeiras imagens do universo concentracionário a serem exibidas para o grande público, servindo também de base para as produções cinematográficas posteriores. No caso específico das imagens produzidas pelos exércitos britânico e americano houve um esforço direto dos comandos militares aliados de registrar a brutalidade encontrada na liberação dos campos em território alemão sob domínio do $3^{\circ}$ Reich, com a clara intenção de impedir que tais crimes, quase inacreditáveis devido à escala do horror encontrado, pudessem ser objeto de descrença futura ${ }^{24}$. As filmagens também tinham função jurídica, como prova para os futuros julgamentos dos líderes nazistas e membros da SS diretamente ligados aos massacres perpetrados.

Essas imagens alcançaram o mundo ao serem exibidas em salas de cinemas comerciais de grandes cidades através dos cinejornais cujo tema era o fim da guerra na Europa e a liberação dos campos. Poucas semanas após a rendição alemã, diversas salas de cinema nos Estados Unidos exibiram o que se convencionou chamar, à época, de "atrocidades nazistas". Tais filmes reuniam as diversas imagens produzidas pelos exércitos nas libertações dos campos de concentração de Bergen-Belsen, Buchenwald, Ohrdruf e Dachau. Os registros exibiam a escala do massacre evidenciado através das imensas pilhas de corpos das vítimas, os milhares de sobreviventes recebendo os primeiros socorros de equipes da Cruz Vermelha Internacional, grupos SS sob custódia dos militares aliados e residentes alemães das cidades próximas aos campos, obrigados

\footnotetext{
${ }^{23}$ SANCHEZ-BIOSCA, op. cit., p. 143.

${ }^{24}$ Ibidem.
} 
pelas forças aliadas a testemunhar o resultado de mais de uma década de regime de Hitler na Alemanha.

\subsection{O olhar do cinema para a tragédia judaica}

Os filmes sobre o Holocausto produzidos nos anos imediatamente posteriores ao fim da guerra já traziam a marca do novo conflito político da Guerra Fria. Muitas produções cinematográficas dos países sob influência soviética, por exemplo, apesar da autenticidade de sua proximidade no tempo e com os cenários dos massacres, frequentemente tinham que se adequar ao ideal político do stalinismo. Foi o caso da produção polonesa "The Last Stop" (1947), filmada em Auschwitz com elenco formado em sua maioria por sobreviventes desse campo de extermínio ${ }^{25}$. No caso da Alemanha derrotada, tanto na zona sob influência americana quanto na área sob ocupação soviética, o tom destas primeiras produções fílmicas quase sempre reforçava o caráter de vítima da imensa maioria da população alemã, seduzida e oprimida pelo nazismo.

Dentro da análise aqui proposta é importante destacar que na grande maioria dos casos nenhuma destas produções cinematográficas retratava o protagonismo da população judaica na perseguição e violência nazista. As narrativas cinematográficas ou documentários quase sempre mencionavam os judeus como parte de um imenso espectro das vítimas do Terceiro Reich entre as quais se encontravam comunistas, opositores do regime, membros da resistência, entre outros. "Noite e Neblina" (1955), de Alan Resnais, primeiro documentário apresentado como um filme de montagem a partir das primeiras imagens registradas na libertação dos campos, é um destes exemplos. O cineasta francês produziu o filme como parte das comemorações pelo $10^{\circ}$ aniversário da libertação dos campos. O filme de Resnais apresenta claramente um discurso político e faz referência aos próprios conflitos da política externa francesa (em relação à crise na Argélia) e aos campos de internamento stalinistas. Conforme afirma Sanchez-Biosca a respeito do documentário de Resnais:

\footnotetext{
${ }^{25}$ O filme polonês "The Last Stop" (1947) foi dirigido por Wanda Jakubowska. Tanto esta diretora como a roteirista do filme, Gerda Schneider, haviam sido prisioneiras em Auschwitz. A experiência de ambas no campo de extermínio foi fundamental para um retrato realista das atribulações sofridas pelas mulheres prisioneiras do campo. In: BARON, Lawrence. Projecting the Holocaust into de present: the changing focus of contemporary Holocaust cinema. Oxford: Rowmann \& Littlefield Publishers, 1995, p. 25.
} 
Auschwitz não estava no olho do furacão, e o extermínio dos judeus e dos ciganos não é o objeto específico de "Noite e Neblina". (...) Como afirma Annete Wierviorka, "Noite e Neblina" parte do pressuposto de um único campo mítico, aberto em 1933 e liberado em 1945, no qual judeus e não-judeus tiveram a mesma sorte." 26

No caso das produções cinematográficas norte-americanas, as primeiras representações a respeito do Holocausto e do nazismo a partir de 1945 tinham como tema a caça e captura de fugitivos nazistas e julgamentos de ex-oficiais do regime por crimes de guerra ${ }^{27}$. Tais filmes reforçavam o caráter universalista do Holocausto e o genocídio da população judaica permanecia subsumido nas categorias de crimes de guerra e crimes contra a humanidade. Há que se considerar também que a partir de 1947 o comunismo substituiu o totalitarismo nazista como o elemento a ser combatido no cenário político americano, o que explica em parte a pouca atração do Holocausto como um tema a ser explorado pela grande indústria do cinema.

Em um estudo sobre a presença da representação cinematográfica do Holocausto no cinema americano, Judith Doneson afirma que mesmo no cenário repressor da conjuntura política da Guerra Fria e do Macartismo - que assombrou os estúdios de Hollywood ao denunciar a presença dos comunistas da indústria cinematográfica - havia uma atitude mais liberal em relação a temas como antissemitismo e segregação racial, em comparação com os anos anteriores à Segunda Guerra Mundial. Foi neste cenário de maior integração da comunidade judaica norte-americana, a partir da década de cinquenta, que foi produzido o filme "O Diário de Anne Frank” (1959).

A versão cinematográfica do "Diário" foi feita sete anos após a primeira edição do livro nos Estados Unidos, que tornou-se instantaneamente um best-seller. Ao ser traduzido para diversas línguas, "O Diário" inaugurou também o processo de globalização do tema. A mudança na percepção do público com "O Diário de Anne Frank" está relacionada com a maior empatia por parte do espectador americano com as vítimas, personificadas através da jovem Anne e sua família. Conforme já mencionado, os poucos filmes produzidos no período anterior quase sempre se baseavam ou utilizavam imagens de arquivo da libertação dos campos de concentração para ilustrar suas narrativas, procurando reforçar o caráter realista dessas representações. Nestas produções, as vítimas do nazismo estavam personificadas em uma massa anônima que

\footnotetext{
${ }^{26}$ SANCHEZ-BIOSCA, op. cit., p. 153. (Trad. do autor). No original: "Auschwitz no estaba en el ojo del huracán y el exterminio judío (y gitano) no es el objeto específico de Noche y niebla (...). Como senãló Annette Wieviorka, Noche y niebla parte del supuesto de un único campo mítico abierto en 1933 y liberado en 1945 en el que judíos y no judíos habrían corrido la misma suerte".

${ }^{27}$ BARON, op. cit, p. 24.
} 
não possibilitava uma identificação do público espectador com uma história específica.

Em relação a sua narrativa e formato cinematográfico, "O Diário de Anne Frank" manteve as prerrogativas desse universalismo. A despeito da impossibilidade de negar a identidade judaica de Anne Frank e dos outros personagens do filme, esse aspecto é minimizado na narrativa, tanto no auto percepção da jovem protagonista quanto em algumas cenas. Pode-se afirmar que o filme "O Diário de Anne Frank" reflete o estado de espírito do pós-guerra nos Estados Unidos em que a catástrofe da Segunda Guerra Mundial engendrou uma mensagem universalista para os perigos do fascismo e do totalitarismo. A perseguição aos judeus foi o pano de fundo para apresentar as consequências do racismo e da discriminação racial como política de estado. O sofrimento de Anne serviu de exemplo para o sofrimento de minorias étnicas e de toda a humanidade. Em relação à política interna norte-americana o próprio ambiente de medo e apreensão do macarthismo foi de alguma maneira denunciado no filme, ao criar uma conexão entre a delação que resultou no destino trágico das famílias escondidas no anexo com os cidadãos americanos perseguidos pela patrulha anticomunista vítimas de investigação após denúncias anônimas ${ }^{28}$.

Em 1961, dois anos após o lançamento de "O Diário de Anne Frank", outro longa-metragem recuperava o passado das atrocidades nazistas, centrado agora na questão da responsabilidade coletiva dos alemães pelo Holocausto. Produzido a partir de uma versão prévia feita para a TV em 1959, “Julgamento em Nuremberg” (1961), dirigido por Stanley Kramer, foi o primeiro filme americano sobre o tema ao combinar ficção e história, inserindo cenas da libertação dos campos registradas pelo exército americano. As filmagens ocorreram no mesmo momento em que o ex-oficial nazista Adolf Eichman foi capturado na Argentina e levado pelo serviço secreto israelense para julgamento em Jerusalém.

Com uma produção comercial considerável, o filme reunia um elenco de grandes estrelas, como Spencer Tracy, Maximilian Schell, Montgomery Clift, Marlene Dietrich, Judy Garland, entre outros. O filme de Stanley Kramer, ao mesmo tempo em que aponta a culpa dos alemães pelos crimes cometidos durante o período nazista, os absolve em parte ao afirmar que no fundo, todos são culpados (as nações aliadas são apontadas como responsáveis por não se esforçarem para impedir as atrocidades do regime). $\mathrm{O}$ traço mais importante a ser destacado em "Julgamento em Nuremberg", no entanto, é a

\footnotetext{
${ }^{28}$ DONESON, Judith. The Holocaust in American film. Syracuse: Syracuse University Press, 2002, p. 82.
} 
total diluição da especificidade judaica do Holocausto, mantendo o discurso universalista presente em "O Diário de Anne Frank". Há uma única menção a um personagem judeu executado por crime contra a raça ao manter relações sexuais com uma mulher ariana. Na exibição das imagens documentais da libertação dos campos de Bergen-Belsen e Buchenwald, os judeus são mencionados entre as outras tantas vítimas das várias nacionalidades europeias. Marcado mais por seus diálogos intensos do que por uma narrativa visual, "Julgamento em Nuremberg" levanta questões de responsabilidade individual, nacional e universal mas tal abordagem é construída de maneira a ser melhor absorvida pelo público médio. A quase não referência ao caráter judaico do Holocausto no filme parece revelar que, à época de sua produção, esse tema ainda estava restrito à própria comunidade. ${ }^{29}$

A década de 60 foi marcada nos Estados Unidos por um período de turbulência social, exemplificado principalmente através dos conflitos pelos direitos civis da população negra. Tal movimento, marcado pela violência e morte de alguns líderes e simpatizantes da causa no sul do país e pelos tumultos em bairros negros nos grandes centros urbanos deu início a uma cisão entre as minorias negras e judaicas, sobretudo pelo aumento do antissemitismo por parte de alguns líderes do movimento negro. "O Homem do Prego" (The Pawnbroker, 1965), filme dirigido por Sidney Lumet, surge neste ambiente de conflito social. O filme narra a história de um judeu sobrevivente, proprietário de uma casa de penhor no Harlem, que perdeu a esposa e a filha durante o Holocausto. Sua relação de distanciamento com a população negra e porto-riquenha no Harlem sugere um paralelo entre a postura de indiferença dos alemães em relação aos judeus durante o nazismo e sua própria indiferença para com seus vizinhos do bairro. Em "O Homem do Prego", a narrativa parece apontar que o personagem judeu não absorveu de maneira suficiente as lições do Holocausto, na sua relação com outros grupos minoritários de sua vizinhança ${ }^{30}$.

\footnotetext{
${ }^{29}$ Ao analisar as relações entre a cultura popular e a formação da memória do Holocausto nos Estados Unidos, Alan Mintz afirma que, baseado em sua experiência pessoal como judeu e espectador do filme durante a adolescência, seu significado para a comunidade judaica era bastante claro, a despeito da quase diluição dessa identificação étnica no próprio filme. MINTZ, Alan. Popular Culture and the Shaping of Holocaust Memory in America. Seattle: University of Washington Press, 2001, p. 103.

${ }^{30}$ DONESON, op. cit., p. 112.
} 


\subsection{O Holocausto na televisão norte-americana}

No caso específico dos Estados Unidos, a televisão tem desempenhado um papel central no estabelecimento do imaginário público a respeito do conhecimento histórico. Devido ao alcance global de distribuição das produções televisivas norte-americanas este efeito ultrapassa fronteiras e tem escala mundial. Na própria sociedade norteamericana, a televisão tem cada vez mais ultrapassado o cinema como um comunicador dominante da cultura, conforme nos aponta Judith Doneson ${ }^{31}$. O estabelecimento do Holocausto como um traço cultural norte-americano está diretamente relacionado com a influência da mídia televisiva neste processo. Curiosamente, são recentes os estudos que se debruçam sobre a presença da memória do Holocausto nas representações televisivas nos Estados Unidos. A esse respeito opina Jeffrey Shandler: "a forma cultural mais óbvia e onipresente de memória do Holocausto nos Estados Unidos - sua presença na televisão - é também a mais negligenciada." ${ }^{, 32}$

É necessário considerar um aspecto importante que diz respeito à natureza do próprio meio e sua sedimentação em relação ao público, um processo que se deu em concomitância com o próprio evento histórico do Holocausto. Shandler afirma que outros meios e formas de representação do Holocausto como romances, relatos memorialísticos, peças de teatro ou filmes já haviam estabelecido suas convenções, protocolos e limites estéticos quando a tragédia do Holocausto aconteceu. A televisão era um meio relativamente novo ao lidar com o tema. Sua própria trajetória como veículo midiático é concomitante à memória deste evento histórico.

O período de 1945 a 1960 é marcado pelas primeiras exibições de programas, filmes e documentários sobre as atrocidades do regime nazista. Nestes anos, a televisão utilizou-se de outras formas de mediação como filmes de arquivo, reportagens emitidas no rádio, relatos históricos e testemunhos orais ao apresentar a sua programação sobre o tema $^{33}$. Os testemunhos orais desempenharam um papel de destaque em programas de televisão da época, recuperando a história de alguns sobreviventes que se estabeleceram

\footnotetext{
${ }^{31}$ DONESON, op. cit., p. 144.

32 SHANDLER, Jeffrey. While American Watches: televising the Holocaust. New York: Oxford University Press, p. xv. (Trad. do autor). No original: "the most obvious and ubiquitous form of Holocaust memory culture in America - its presentation in Television - is also the most overlooked."

${ }^{33}$ Idem, p. 2.
} 
nos Estados Unidos. O episódio do programa "This is your Life" exibido pelo canal de TV NBC (National Broadcasting Company) exibido em maio de 1953 foi um desses exemplos. Centrado na história de Hannah Kohner, uma sobrevivente judia oriunda da região dos Sudetos que esteve em Auschwitz e Mauthausen, o programa apresentou o relato pessoal de Hannah como foco principal, recuperando sua história traumática e possibilitando reencontros com antigos amigos e parentes, tendo como ilustração fotos e registros fílmicos do período nazista ou da liberação dos campos de concentração.

No mesmo período alguns teledramas foram veiculados na TV em exibições ao vivo tendo como pano de fundo histórias individuais de vítimas e sobreviventes do Holocausto. A despeito da presença do tema em um meio de amplo alcance de audiência, roteiristas e produtores ainda enfrentavam o desafio de apresentar o drama do antissemitismo e da perseguição nazista para não-judeus em uma época em que a própria comunidade judaica ainda estava reticente na afirmação de sua identidade étnica ${ }^{34}$. Antes da versão cinematográfica de 1959, "O Diário de Anne Frank" foi adaptado em um teledrama exibido ao vivo em novembro de 1952, poucos meses depois da tradução do livro para a língua inglesa. Outros teledramas exibidos na mesmo época foram "In the Beginning”, exibido em 1956, e "The Final Ingredient" (1959), estrelado por John Cassavetes. Como mencionado anteriormente, "Julgamento em Nuremberg" teve uma primeira versão para a televisão, exibida em 1959, antes da versão para o cinema de 1961.

Há um relativo consenso de que o grande marco da presença do Holocausto na televisão americana antes do advento da minissérie "Holocausto" foi a exibição do julgamento de Adolf Eichmann em Jerusalém no ano de 1961. O julgamento de Eichmann foi um marco na compreensão geral do público americano e mundial sobre o extermínio da população judaica europeia. Transmitidas para o mundo inteiro pela televisão, as sessões da corte em Jerusalém pela primeira vez destacaram o genocídio contra a população judaica do espectro mais amplo dos crimes de guerra nazistas. Em relação à televisão, foi a primeira vez em que os canais de TV abordaram o Holocausto como um tema noticioso. O julgamento também levantou questões sobre como os

\footnotetext{
${ }^{34}$ Idem, p. 47.
} 
canais de TV conceitualizam a História ao fazerem a cobertura jornalística de eventos atuais. $^{35}$

Peter Novick esclarece que foi a partir do julgamento de Eichmann que o termo Holocausto passou a designar, entre os americanos e posteriormente para o mundo inteiro, a perseguição e o extermínio da população judaica na Europa, como uma entidade distinta do barbarismo genérico executado pelo regime nazista ${ }^{36}$. O termo foi utilizado correntemente na cobertura televisiva do julgamento. Para a comunidade judaica, o julgamento de Adolf Eichmann e sua transmissão para o grande público também foi o divisor de águas em sua relação com essa memória. A mudança do status do Holocausto no imaginário dos americanos não-judeus resultou no encorajamento da própria comunidade para um maior entendimento e divulgação desse evento histórico ${ }^{37}$.

Embora o tema do Holocausto tenha surgido eventualmente na programação televisiva americana em documentários, teledramas e séries após 1961, um impacto maior no grande público a respeito deste tema só seria alcançado 16 anos mais tarde através da exibição da minissérie de mesmo nome e que é o objeto desta análise.

\subsection{Teledramas históricos em horário nobre}

Para uma compreensão mais ampla do impacto produzido pela produção e posterior exibição da minissérie "Holocausto" em 1978 uma breve explanação sobre a natureza da programação televisiva e a evolução do formato minissérie na teledramaturgia norte-americana se faz necessária. É necessário sobretudo analisar a importância do surgimento de narrativas de fundo histórico em produções de exibição diária consecutiva e o impacto social produzido com tais exibições. Esta mudança na estrutura programática das séries de televisão desempenhou um importante papel na recepção das narrativas veiculadas e no consequente debate produzido após sua exibição em horário nobre, um dos objetos de análise desta investigação.

A forma dramática que rege o sentido narrativo das minisséries com temas históricos é um aspecto de grande importância em qualquer análise sobre obras

\footnotetext{
${ }^{35}$ SHANDLER, op. cit., p. 84.

${ }^{36}$ NOVICK, Peter. The Holocaust and Collective Memory. London: Bloomsbury, 2000, p. 133.

${ }^{37}$ MINTZ, Alan. op. cit., p. 12.
} 
audiovisuais desta natureza. Ao investigar os liames entre cinema, televisão e histórica, a historiadora Mônica de Almeida Kornis chama a atenção para a importância da forma dramática que fundamenta o sentido de algumas narrativas históricas, recuperando os estudos sobre o melodrama e sua aplicação nas várias formas de produção ficcional, incluindo as produções audiovisuais ${ }^{38}$. A historiadora destaca a importância da obra do teórico da literatura Peter Brooks como uma contribuição que possibilitou uma nova orientação dos estudos nesta área, sobretudo a partir da publicação de sua obra The Melodramatic Imagination: Balzac, Henry James, Melodrama and the Mode of Excess (1976).

A peça dramática "Celina ou a filha do mistério" de Gilbert de Pixerécourt, de 1800, é considerada a primeira produção do gênero melodramático. Resultado do alcance cada vez maior do entretenimento de massa, sobretudo com o maior acesso da população aos teatros após a Revolução Francesa, o melodrama revelou o surgimento de um teatro popular que se adaptava ao nível cultural do novo público. Mantendo os acessórios musicais do vaudeville, o gênero carregava no drama sentimental, apresentando narrativas de maior seriedade, quase sempre com desfecho trágico. Além de explicitar a sua estrutura tripartite, Arnold Hauser nos oferece esse esquema explicativo sobre o gênero e sua diferença em relação à tragédia clássica:

uma trama facilmente entendida e economicamente desenvolvida; com a
prioridade da trama sobre os personagens; com figuras bem definidas: o herói,
a inocência perdida, o vilão e o cômico; com a cega e cruel fatalidade dos
acontecimentos; com uma moral fortemente enfatizada, que, por sua tendência
insípida e conciliatória, baseada em recompensa e castigo, discorda do caráter
moral da tragédia, mas compartilha com esta uma elevada, embora exagerada,
solenidade. $" 39$

Embora a análise de Peter Brooks mereça uma apresentação mais detalhada que considere inclusive uma abordagem crítica da gênese de uma "imaginação melodramática" vinculada ao contexto social da modernidade burguesa, vamos nos ater aqui à sua tese central, recuperada frequentemente nas discussões a respeito de narrativas audiovisuais. Segundo Brooks, na sociedade pós-Antigo Regime o melodrama cumpre, de certa forma, um papel regulador na nova ordem moral da modernidade laica burguesa. A destruição ou o questionamento de instituições tradicionais como a Monarquia e a Igreja evidenciam a "dissolução de uma sociedade

\footnotetext{
${ }^{38}$ KORNIS, Mônica de Almeida. Cinema, televisão, história. Rio de Janeiro: Zahar, 2008, p. 47.

${ }^{39}$ HAUSER, Arnold. História social da arte e da literatura. São Paulo, Martins Fontes, 1995, p. 703.
} 
orgânica e hierarquicamente coesa e a desvalorização de formas literárias (...) que dependem de tais sociedades." ${ }^{40}$ As experiências ficcionais surgidas nesse contexto reproduziriam tal imaginação. Segundo Ismail Xavier:

Se a moral do gênero supõe conflitos, sem nuances, entre o bem e o mal, se oferece uma imagem simples demais para os valores partilhados, isso se deve a que sua vocação é oferecer matrizes aparentemente sólidas de avaliação da experiência num mundo tremendamente instável, porque capitalista na ordem econômica, pós-sagrado no terreno da luta política (sem a antiga autoridade do rei ou da Igreja) e sem o mesmo rigor normativo no terreno da estética. ${ }^{41}$

A força de tal matriz melodramática fica evidente em sua permanência tanto no cinema industrial (adequando-se às demandas do público em diferentes épocas) quanto na produção ficcional televisiva, cuja base folhetinesca em muitos casos explicita as premissas mais básicas do gênero. Monica Kornis enfatiza a proximidade entre o melodrama e o folhetim e o seu poder de adaptação mesmo dentro do processo de evolução das narrativas televisivas para uma abordagem mais realista:

No caso da matriz da produção televisiva, sobretudo ficcional, soma-se à experiência do modelo melodramático a estrutura do folhetim, que, nascido nas primeiras décadas do século XIX, na França, consistia em histórias em capítulos escritas no rodapé das páginas dos jornais com clímax diário para despertar o interesse do leitor no dia seguinte. (...). O poder da estratégia contida nessas narrativas se reciclou ao longo da história do cinema e da televisão, dentro da concepção realista de filmes, telenovelas e minisséries."42

Diferente do seriado, cuja história principal e personagens se repetem em narrativas episódicas distintas, as séries e minisséries não concluem sua história em um episódio, mas reservam o desenrolar da trama para os episódios seguintes. Como define a especialista em estudos audiovisuais Sarah Kozllof, o formato dos seriados está mais próximo a uma antologia de histórias curtas ao passo que as séries são como um romance publicado em folhetins ${ }^{43}$. Glen Creeber, outro especialista neste campo, esclarece que os seriados e séries sedimentaram-se na programação televisiva ao se adequarem e celebrarem a dinâmica específica deste meio. Segundo este autor, "tais

\footnotetext{
${ }^{40}$ BROOKS, Peter. The Melodramatic Imagination: Balzac, Henry James, melodrama and the mode of excess. New Haven: Yale Universty Press, 1995, p. 15 (Trad. do autor). No original: "the dissolution of an organic and hierarchically cohesive society, and the invalidation of the literary forms (...) that depend on such a society."

${ }^{41}$ XAVIER, Ismail. O olhar e a cena. São Paulo: Cosac \& Naify, 2008, p. 91.

${ }^{42}$ KORNIS, op. cit., 50.

43 KOZLOFF, Sarah. Narrative Theory and Television. In: ALLEN, Robert C. (Org.) Channels of Discourse, reassembled: television and contemporary criticism. North Carolina: The University of North Carolina Press, 1992, p. 91.
} 
como as telenovelas, as séries são exibidas regularmente na programação, desenrolandose dentro e fora do espaço doméstico, deliberadamente manipulando e explorando a noção de tempo dos espectadores de um modo jamais imaginado antes pelo cinema ou pelo teatro ${ }^{44}$ ". Outra distinção importante diz respeito a dois aspectos frequentes deste formato narrativo televisivo: a intimidade e a continuidade. É o intenso envolvimento do espectador com os dramas pessoais dos personagens que torna possível acompanhar a narrativa durante a sequência de episódios ${ }^{45}$.

Segundo o teórico de cinema Ismael Xavier, no formato audiovisual da minissérie pode-se verificar o drama em sua clássica ternária de abertura, desenvolvimento, e desfecho: "Essa espécie de economia, em oposição ao desenvolvimento prolongado e frouxo de uma telenovela de seis meses, torna mais visível o pendor pedagógico tanto do enredo como dos diálogos" 46 . Para as minisséries de fundo histórico, como "Holocausto", aliado às narrativas pessoais e familiares que exercem a função de manter o interesse do telespectador, a função pedagógica é um elemento primordial.

Com origem na televisão britânica, a minissérie era um formato de narrativa audiovisual relativamente novo nas redes de televisão norte-americanas na década de 70. Enquanto o modelo britânico privilegiou adaptações de romances clássicos da literatura inglesa, a transposição para o público norte-americano centrou-se na adaptação de best-sellers de sucesso, iniciando com o romance "QB VII" de Leon Uris, exibido em duas noites consecutivas em 29 e 30 de Abril de 1974 pela rede de televisão $\mathrm{ABC}^{47}$. O primeiro grande sucesso de público em horário nobre, no entanto, foi a minissérie "Rich Man, Poor Man” (1976), baseada no romance de Irwin Shaw, exibida também pelo canal $\mathrm{ABC}$ às segundas-feiras de $1^{\circ}$ de Fevereiro a 15 de Março. Com relativo sucesso de crítica e bons índices de audiência, estas duas produções deram ao

\footnotetext{
${ }^{44}$ CREEBER, Glen. Taking our personal lives seriously: intimacy, continuity and memory in the television drama serial. Media Culture Society. Sage Publications, n. 23, 2001, p. 441 (Trad. do autor). No original: "Like the soap opera, the series reoccurs regularly throughout the schedule, weaving in and out of the domestic space and deliberately tapping into and playing with na audience's sense of time in a way never imagined before by the cinema, theatre or single play."

${ }^{45}$ Idem, p. 442.

${ }^{46}$ XAVIER, Ismail. op. cit, p. 144.

${ }^{47}$ DE VITO, John, TOPEA, Frank. Epic television miniseries: a critical history. North Carolina: MacFarland \& Company, 2010, p. 17.
} 
formato minissérie um maior prestígio em relação a outros gêneros de entretenimento televisivo $^{48}$.

Em 1977, quase um ano depois, estreava o drama histórico que se tornou o grande marco televisivo em horário nobre e que, por conta do grande impacto produzido por sua veiculação, definiria o formato das minisséries em anos posteriores, influenciando também na produção de "Holocausto".A adaptação televisiva do romance recém-publicado de Alex Haley, "Raízes", alcançou o recorde de 130 milhões de telespectadores. A transmissão de seu último episódio ultrapassou em audiência a exibição na TV do filme "...E o Vento Levou", que era grande marco de audiência ${ }^{49}$. Dirigida por Marvin J. Chomsky e produzida pelo canal de TV ABC, "Raízes" foi exibida em oito episódios, de 23 a 30 de janeiro. A mudança da exibição semanal para a diária foi a grande novidade introduzida na programação do canal, além da ênfase em um drama televisivo de fundo histórico em detrimento de narrativas policiais e de aventura. $^{50}$

O livro de Haley foi publicado em 1976 com o título original de "Roots: the saga of an american family" e reconstrói a história oral dos antepassados do autor, iniciando sua narrativa no século XVIII, em uma aldeia próxima a Juffure, às margens do rio Gâmbia, na África. Neste local, Kunta Kinte, filho de um guerreiro mandingo, é capturado por mercadores de escravos e, após uma tortuosa travessia em um navio negreiro, chega a Maryland, nos Estados Unidos. O jovem escravo é vendido em um leilão para um fazendeiro da Virginia que dá a ele o nome de Toby. Disposto a lutar por sua liberdade e manter a sua herança cultural de mandingo, Kunta Kinte tenta escapar do cativeiro diversas vezes, sem sucesso, e recusa-se a aceitar o nome escolhido por seu senhor. Posteriormente subjugado pela violência do regime escravista, o africano acaba casando-se com Belle, uma escrava cozinheira com quem tem uma filha, a quem ele chama de Kizzi. É Kizzi quem dá continuidade à narrativa genealógica iniciada por Kunta Kinte ao longo de todo o século XIX, passando pelos principais eventos históricos do sul escravocrata. "Chicken" George, filho de Kizzi e primeiro membro da família a obter a alforria e a liberdade antes mesmo da abolição da escravatura, refaz a

\footnotetext{
${ }^{48}$ SHANDLER, op. cit., p. 160.

${ }^{49}$ HOWARD, John. ROTHBART, George. SLOAN, Lee. The response to "Roots": a national survey. Journal of Broadcasting. n. 22, p. 279.

${ }^{50}$ FISHBEIN, Leslie. Roots: Docudrama and the Interpretation of History. In: ROSENTHAL, Alan (Org). Why Docudrama? Fact-Fiction on Film and TV. Illinois: Southern Illinois University Press, 1999, p. 272.
} 
conexão do núcleo familiar à sua ancestralidade africana, em um momento posterior à Guerra Civil e à própria abolição, rememorando seu avô Kunta Kinte. Alex Haley termina o seu romance reconstruindo a linhagem que o liga a "Chicken" George e consequentemente aos seus antepassados africanos.

"Raízes" tornou-se o maior evento televisivo de 1977 na televisão norteamericana. Produzida um ano após o bicentenário da independência, ainda no clima comemorativo do período, a minissérie foi o primeiro programa de televisão a apresentar para o grande público um elenco majoritariamente negro em um drama em que os vilões eram, em sua maioria, brancos. É importante acrescentar que a narrativa dramática de "Raízes" recuperou o passado traumático da escravidão para o público dos Estados Unidos sob a perspectiva dos negros escravizados. A historiadora Alison Landsberg afirma que, ao escrever seu romance, Alex Haley esperava atrair seus leitores de uma maneira afetiva e visceral ${ }^{51}$. Esta narrativa familiar transplantada para a televisão cumpre de maneira eficiente este objetivo, apresentando um personagem negro com o qual o público cria uma identificação imediata: "através de cenas do ponto de vista de Kunta Kinte, a minissérie permite que os telespectadores brancos pudessem ver através do olhar de um homem negro." ${ }^{, 52}$

Além da mudança no formato de exibição que influenciou a produção posterior de outras minisséries, três aspectos de "Raízes" interessam diretamente à nossa análise. O primeiro deles diz respeito aos eventos da história (mais especificamente da história norte-americana) que acompanham a trajetória familiar de Kunta Kinte e seus descendentes. O público testemunha, enquanto telespectador, a dinâmica violenta do tráfico de escravos, desde a captura de cativos na África, passando pela travessia do Atlântico em navios negreiros até o leilão dos aprisionados na América. As condições subumanas dos escravos nas fazendas do sul do país, os dolorosos castigos exemplares para as inúmeras tentativas de fuga, a Guerra Civil Americana e a segregação racial são passagens históricas apresentadas paralelamente à narrativa dos personagens principais, fornecendo ao público o elo de identificação entre esta experiência familiar e seus dramas cotidianos com a processo histórico mais amplo, cujas contradições raramente são exibidas em um meio tão popular como o televisivo. "Raízes" e "Holocausto"

\footnotetext{
${ }^{51}$ LANDSBERG, Alisson. Prosthetic Memory: the transformation of American remembrance in the age of mass culture. New York: Columbia University Press, 2004, p. 101.

${ }^{52}$ Idem, p 103 (Trad. do autor). No original: "By granting Kunta Kinte point-of-view shots, the miniseries enabled white viewers to see through a black man's eyes."
} 
inauguraram a dramatização seriada de narrativas históricas complexas na televisão que, mesmo com alguma simplificação intrínseca ao meio, alcançaram uma ampla audiência e permitiram a discussão pública desses eventos históricos. Glen Greeber afirma que as minisséries rapidamente demonstraram o potencial do formato para falar sobre temas históricos de difícil abordagem e de grande amplitude:

\begin{abstract}
ambas foram literalmente a primeira tentativa de trazer para a ficção as atrocidades da escravidão e do holocausto nazista para uma grande audiência global (...) demonstraram de um modo efetivo o poder da televisão ao abordar graves problemas históricos, trazendo-os de maneira catártica para a discussão pública, em alguns casos pela primeira vez. ${ }^{53}$
\end{abstract}

O debate público é o segundo aspecto a ser enfatizado por representar outro traço comum para ambas as produções televisivas. O impacto da exibição de "Raízes" ultrapassou o espaço doméstico e se refletiu nas discussões públicas a respeito do drama exibido. Esta experiência coletiva compartilhada através da televisão para uma audiência diversificada, em exibição diária consecutiva, foi uma das explicações para uma ampla discussão social em nível nacional, como poucas vezes uma produção de televisão foi capaz de fomentar. A minissérie foi tema recorrente em conversas, programas de rádio, discussões em escolas e sermões religiosos. ${ }^{54}$

A discussão a respeito do violento passado escravista norte-americano - cuja representação realista nos meios audiovisuais permaneceu como um tabu durante um longo período despertou preocupações a respeito do acirramento de possíveis tensões sociais $^{55}$. De maneira geral, pesquisas sobre a recepção da minissérie demonstraram que a exibição de "Raízes" ocorreu em um momento de ambiguidade racial na sociedade americana, um período marcado ainda pela proximidade em relação às conquistas dos direitos civis e tumultos raciais do início da década de 60. A minissérie era claramente resultado de mudanças nas relações sociais nos Estados Unidos, mas, segundo as conclusões da pesquisa, não estava claro se brancos e negros caminhavam na mesma direção ou se havia uma polarização em dois grupos sociais distintos. ${ }^{56}$

\footnotetext{
${ }^{53}$ CREEBER. op. cit., p. 442 (Trad. do autor). No original: ""both were literally the first attempt to fictionalize the atrocities of slavery and the Nazi Holocaust for a worldwide mainstream audience (...) demonstrated the power of the television serial to tackle serious historical issues, cathartically bringing them out into the public domain for discussion, frequently for the first time".

${ }^{54}$ LANDSBERG, op. cit., p. 103.

${ }_{56}^{55}$ HOWARD, op. cit., p. 279.

${ }^{56}$ Idem , p. 286.
} 
Chegamos finalmente ao terceiro aspecto e que está mais diretamente ligado às questões levantadas nesta investigação. O livro de Alex Haley e a posterior produção da minissérie marcaram uma clara mudança na relação dos negros com suas origens africanas. De acordo com Alison Landsberg, "Raízes” contribuiu de alguma maneira para o fenômeno da "América hifenizada", "marcando o momento em que as pessoas de cor negra começaram a alterar a auto percepção de negros para afro-americanos." Landsberg destaca o fato de que o livro de Haley foi publicado em 1976, ano da celebração do bicentenário da independência dos Estados Unidos. Para esta historiadora, a brutalidade do tráfico negreiro e da escravidão que permeia a história dos ancestrais de Alex Haley representou uma espécie de contranarrativa em meio às comemorações da história oficial norte-americana.

"Raízes" despertou um interesse sem precedentes entre os diversos grupos étnicos a respeito de suas origens e ancestralidade. Ao se referir a esse movimento, um artigo da revista Times afirmou que os norte-americanos: "se tornaram como filhos adotivos que exigem conhecer um passado que durante um longo tempo lhes foi negado" ${ }^{, 58}$. Pode-se afirmar que a redescoberta e a valorização das raízes ancestrais dos diversos grupos étnicos deve muito ao livro de Alex Haley e à sua posterior adaptação através da minissérie, provocando um conhecimento muito mais amplo ao alcançado pela publicação. De acordo com o historiador Matthew Frye Jacobson, "Raízes" foi importante como um fenômeno nacional: "não somente porque o livro e a minissérie foram ansiosamente consumidos por milhões em todo o país, mas por que, ao longo do tempo, a linguagem da ancestralidade redefiniu a própria retórica da nação." 59

Independente do pouco aprofundamento das discussões sobre o passado escravista e as relações raciais nos Estados Unidos despertadas com a exibição de "Raízes", o fato é que sua exibição e a posterior produção e exibição de "Holocausto" um ano depois ocorreram em um momento de celebração das diferenças étnicas e da valorização do status de vítima de alguns grupos. Esta celebração esteve diretamente

\footnotetext{
${ }^{57}$ LANDSBERG, op. cit., p. 102 (Trad. do autor). No original: "marking the moment when people of color began to change their self-understanding from black to African-American."

${ }^{58}$ JACOBSON, Matthew Frye. Roots too: white ethnic revival in post-civil rights America. Cambridge: Harvard University Press, p. 42. (Trad. do autor). No original: "have become like those adoptees who demand the long-denied knowledge of heritage."

${ }^{59}$ Idem. No original: "not only because the book and the minisséries were so eagerly devoured by millions across the country, but because, over time, the roots idiom revised the vernacular imagery of the nation itself."
} 
vinculada com a recuperação do passado por meio de um discurso de memória, nos dois casos permeados por narrativas mesclando história e ficção veiculadas na televisão, um meio de comunicação de grande alcance.

O passado traumático, para ambos os casos, serviu como o elemento aglutinador destas comunidades étnicas e as narrativas apresentadas nestas duas produções audiovisuais funcionaram como lugares de memória, fornecendo a estas próprias comunidades elementos de identificação através da ficção histórica. Para Judith Doneson, tanto "Raízes" como "Holocausto" refletem a emergência das consciências étnicas norte-americanas que se seguiu à luta pelos direitos civis: “...ao menos no nível da cultura popular, o Holocausto tem frequentemente servido como metáfora da luta dos negros, e a história destes forneceu o precedente para "Holocausto"60. Em uma análise sobre as relações entre o Holocausto e o judaísmo norte-americano o pesquisador e rabino Jacob Neusner considera que na aproximação entre "Raízes" e "Holocausto" está a concepção de que ser judeu é fundamentalmente uma questão étnica e não religiosa:

Por quase um século os judeus americanos convenceram a si mesmos e a seus vizinhos que eles se encaixavam na categoria de diferenciação religiosa (e portanto aceitável) e não na categoria de diferenciação étnica (e portanto deformada e indesejada). Agora que eles não têm mais nenhum sotaque judeu, eles desejam ser étnicos. ${ }^{61}$

Essa discussão será aprofundada após a análise fílmica da minissérie mas faz-se necessário aqui destacar esta concepção étnica do judaísmo norte-americano, evidenciada na sua direta relação com outro documento fílmico contemporâneo à sua produção.

\footnotetext{
${ }^{60}$ DONESON, Judith. op. cit.,. p 145 (Trad. do autor). No original: "at least on the level of popular culture, the Holocaust has often served as metaphor for the black struggle, and black history provided the precedente for Holocaust."

${ }^{61}$ NEUSNER, Jacob. Strangers at Home: 'The Holocaust', Zionism and American Judaism. Chicago: University of Chicago Press, 1981, p. 90. (Trad. do autor). No original "For nearly a century American Jews have persuaded themselves and their neighbors that they fall into the religious - and therefore acceptable - category of being 'different', and not into the ethnic - and therefore crippling and unwanted - category of being 'different'. Now they have no Jewish accent, they are willing to be ethnic."
} 


\section{CAPITULO 2 - "HOLOCAUSTO - A história da família Weiss"}

\subsection{A mobilização da audiência}

A minissérie "Holocausto" estreou na rede de televisão norte-americana NBC em um domingo, 16 de Abril de 1978 e foi exibida em capítulos de aproximadamente uma hora e trinta minutos nos três dias posteriores. Produzida por um estúdio independente, a Titus Film, a minissérie foi dirigida por Martin Chomsky, que havia sido também o diretor de "Raízes", exibida pelo canal ABC (American Broadcasting Company) no ano anterior. Conforme já mencionado, ambas as minisséries foram marcadas por um roteiro calcado em eventos históricos, embora a narrativa de Alex Haley se apoie na tradição oral de seus antepassados. "Holocausto", por outro lado, mesmo tendo como pano de fundo os principais eventos da perseguição aos judeus durante o nazismo, tem como base uma narrativa fictícia centrada na história das vicissitudes enfrentadas por uma família judia-alemã com a chega de Hitler ao poder e o surgimento do Terceiro Reich.

O teledrama foi apresentado em uma programação especial do canal televisivo chamada The Big Event, que normalmente exibia, em horário nobre, dramas, filmes, concertos e retrospectivas, geralmente em datas importantes e com um pronunciado tom épico $^{62}$. Foi a primeira vez no entanto que o canal NBC exibiu, nesta programação especial, uma minissérie. A exibição de "Holocausto" neste formato acompanhou o modelo de sucesso experimentado pela versão televisiva do romance de Alex Haley. De fato, o esforço de divulgação da minissérie, foco desta apresentação prévia que antecede a análise do documento televisivo, evidencia o caráter excepcional que sua exibição representou. Tal esforço contrastou com a divulgação quase mínima de "Raízes", cujo sucesso ocorreu em grande parte na decorrência da exibição dos capítulos diários. Organizações judaicas norte-americanas desempenharam um papel fundamental no esforço de divulgação de "Holocausto", e é este protagonismo que interessa mais diretamente às hipóteses apresentadas nesta investigação.

O roteiro de "Holocausto" é de autoria de Gerald Green, jornalista e romancista judeu que já havia produzido um livro de não-ficção sobre os artistas encarcerados no

\footnotetext{
${ }^{62}$ SHANDLER, op. cit. p. 159.
} 
campo de concentração de Theresienstadt. Além do roteiro, Gerald Green escreveu uma versão romanceada da narrativa de "Holocausto", apresentando alguns personagens da minissérie como narradores em diferentes perspectivas, além de explorar com maior detalhe o destino do único personagem da história que sobrevive à Guerra. A publicação da versão em livro de "Holocausto" fez parte do esforço de divulgação do teledrama

O roteiro recebeu a consultoria de uma das maiores personalidades da comunidade judaica dos Estados Unidos, o rabino Marc H. Tanenbaum, líder religioso diretamente envolvido com causas civis no país. Tanenbaum era o diretor nacional de assuntos inter-religiosos do American Jewish Comitte (AJC). Esta instituição esteve diretamente envolvida no esforço de divulgação da minissérie já que a própria NBC solicitou a alguns de seus membros a consultoria e assistência para o roteiro durante a produção do teledrama. Atendendo ao pedido do canal de televisão, Tanenbaum efetuou uma revisão do roteiro, sugerindo alterações e corrigindo eventuais erros. As sugestões mais pontuais do rabino Marc Tanenbaum em relação ao roteiro serão apresentadas na própria análise a ser apresentada a seguir.

É importante destacar a decisão do canal de televisão de buscar a consultoria de um líder religioso da maior instituição judaica norte-americana em detrimento de um historiador ou de outro pesquisador do Holocausto. Embora não existem evidências documentais para tal decisão, podemos inferir que tal escolha parece estar em conformidade com a estratégia de vincular a minissérie e sua narrativa à comunidade judaica. Mais importante do que a veracidade histórica dos episódios narrados, cujo endosso de especialistas neste campo de investigação não foi ignorado, os produtores procuraram a chancela de uma personalidade de destaque na comunidade judaica cuja preocupação também se expandia para além da acuidade histórica.

As percepções de Marc. H. Tanenbaum a respeito do roteiro de "Holocausto" enviadas a Robert Kasmire, vice-presidente do canal de televisão NBC, revelam sua satisfação com a apresentação de um teledrama sobre o genocídio judaico o grande público por meio da televisão mas também ressaltam a apreensão de que a minissérie seja percebida como mais uma "obsessão judaica" como tema do Holocausto nazista:

Há um perigo real de que esta minissérie do canal NBC possa sofrer as mesmas críticas presentes em uma larga parcela da sociedade em relação ao Holocausto nazista, a saber, de que se trata de "uma obsessão judaica". Para o público majoritário de judeus americanos obviamente ela tem o seu próprio valor mas 
tal percepção poderia anular o propósito maior de elevar a consciência e aprofundar o compromisso moral do povo americano "de não ficar de braços cruzados", enquanto o ódio, o preconceito, violência verbal e assassinato real estão sendo desencadeados contra judeus e contra outros seres humanos. ${ }^{63}$

A preocupação de Tanenbaum mencionada acima é seguida de algumas sugestões relativas à necessidade de vincular a especificidade do massacre nazista contra os judeus a um espectro mais geral, cujo significado poderia estar articulado de uma maneira pessoal pelo público telespectador. Tal vinculação, segundo o rabino, poderia ser adicionada na própria narrativa e no esforço de publicidade da produção do teledrama. Tanenbaum refere-se ao impacto produzido pela exibição de "Raízes", em que os 90 milhões de americanos no geral (e não apenas os 22 milhões de afroamericanos) confrontaram o peso moral da escravidão e do racismo. Nestes termos, diz ele:

Acredito que somente pela compreensão do que significa o nazismo e a ausência de lei para a humanidade em geral, cada ser-humano não-judeu (cristãos, muçulmanos, hindus, animistas, etc.) começará a compreender que todos têm um interesse pessoal ao confrontar o antissemitismo e o Holocausto, como um paradigma para a condição humana especialmente em uma era nuclear. $^{64}$

Passemos então ao esforço de divulgação da minissérie empreendida não apenas pelo Comitê Judaico Americano mas também pela Anti-Defamation League (ADL), principal instituição de combate ao antissemitismo nos Estados Unidos. A ADL distribuiu dez milhões de cópias de seu tablóide "The Record" para promover o teledrama ${ }^{65}$. A publicação, com o título especial de "O Holocausto na História, 19331944" reunia informações sobre a minissérie, uma cronologia dos principais

\footnotetext{
${ }^{63}$ TANENBAUM, Marc. H. Avaliação de roteiro da minissérie "Holocausto", 25 de Julho de 1977. Ao vice-presidente da NBC, Robert Kasmire. The Jacob Rader marcus Center of the American Jewish Archives, caixa 6, pasta 2, série E, arquivo geral alfabético, 1960-1992, p. 3 (Trad. do autor). No original: "There is a real danger that this NBC-TV series could suffer from the same response that exists in large parts of the general society to the Nazi holocaust itself, namely, that this is 'a Jewish obsession'. Were the audience to become mainly American Jews, that obviously would have its own value, but surely it would defeat the larger purpose of raising the consciousness and deepening the moral commitment of the American people 'not to stand idly by' while hatred, prejudice, verbal violence, and actual murder are being unleashed against Jews, and against any other human beings."

${ }^{64}$ Idem, p. 3. (Trad. do autor). No original: "I contend, that it is only by understanding what nazi demonism and lawlessness means for mankind at large, for every living human being, that non-Jews (Christians, Muslims, Hindus, animists, etc.) will begin to understand that they have a personal stake in confronting anti-Semitism and the Nazi holocaust, paradigmatic for the human condition especially in a nuclear-missile-neutron bomb age."

${ }^{65}$ NOVICK, op. cit., p. 64.
} 
acontecimentos relacionados ao genocídio dos judeus na Europa, reproduções de notícias de jornais sobre esses acontecimentos e artigos de sobreviventes e especialistas no tema, como o escritor Elie Wiesel e o próprio roteirista Gerald Green, entre outros.

Pode-se observar, na própria publicação distribuída pela Anti-Defamation League, a exortação aos telespectadores por meio de um discurso de "dever de memória". O texto do editorial do tabloide que apresenta a minissérie recupera uma afirmação do presidente do canal NBC para quem a televisão tem como função ajudar os telespectadores a recuperar o significado de uma frase clássica do filósofo George Santayanna: "aqueles que não lembram o passado estão condenados a repeti-lo" ${ }^{\text {"66 }}$. Um texto do próprio presidente da Anti-Defamation League, Burton M. Joseph, aponta a importância da minissérie não só como um meio para destacar importância do Holocausto (tema que à época ele considerava marginalizado nos currículos escolares) como também como uma reação à edição de obras revisionistas e negacionistas na Europa e nos Estados Unidos declarando, a despeito da extensa documentação e testemunho de sobreviventes, que o Holocausto era na verdade "um mito",67. Em meio aos textos aprofundando os eventos apresentados na cronologia sobre o genocídio judaico na Europa a publicação da ADL também inseriu temas para discussão.

Os assuntos a serem debatidos foram sugeridos em forma de questões tais como: qual sua origem étnica e a qual comunidade pertencem seus antepassados? $\mathrm{O}$ que podemos aprender ao estudar a ascensão do nazismo na Alemanha? Como foi possível ao mundo permanecer paralisado sem interromper a destruição dos judeus?

Paralelamente ao esforço de divulgação da ADL, o American Jewish Committee preparou guias de estudo em forma de brochuras para os telespectadores, destinados a discussão em escolas e comunidades religiosas, com o endosso na National Education Association $^{68}$. Outras instituições judaicas do país juntaram-se ao esforço do AJC no patrocínio de kits especiais para serem usados em escolas judaicas, sinagogas e outros grupos educacionais. No que diz respeito ao diálogo inter-religioso, o AJC preparou para o Conselho Nacional de Igrejas, a Conferência Nacional dos Bispos Católicos e às igrejas evangélicas um guia específico com abordagem para cristãos. Grupos de

\footnotetext{
${ }^{66}$ Special television drama to depict Holocaust. The Record: The Holocaust in History, 1978, p. 1.

${ }^{67}$ Idem, p. 2.

${ }^{68}$ THE AMERICAN JEWISH COMMITTEE. Americans Confront the Holocaust: a study of reactions to NBC-TV's four-part drama on the nazi era. New York, 1978, relatório, p. 2.
} 
educadores, líderes do movimento negro, trabalhista e feminista também receberam informações de divulgação da minissérie para fomentar a atenção dos membros de suas organizações civis ${ }^{69}$

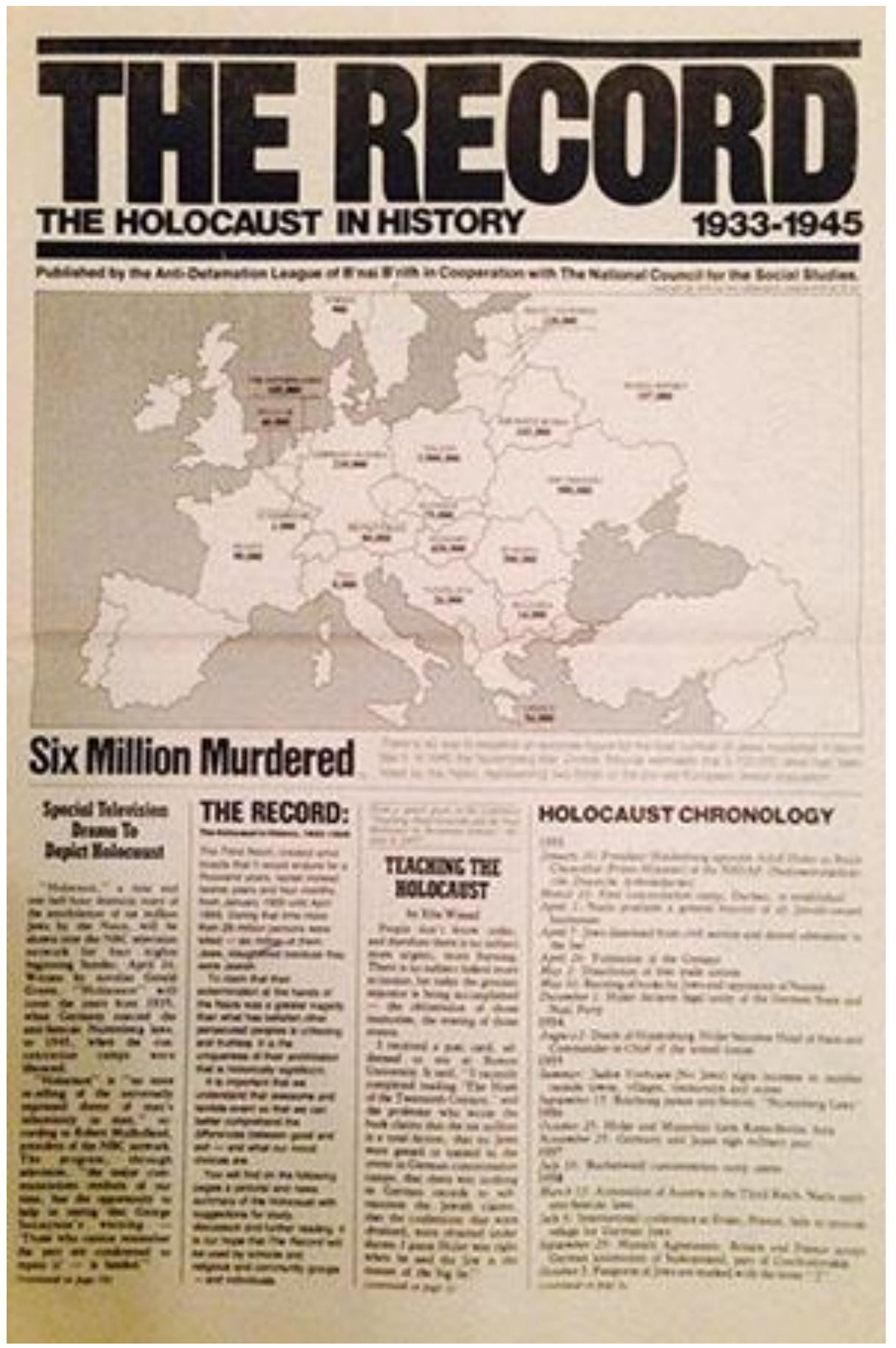

Figura 1 - Fac-símile da primeira página do boletim especial "The Record", produzido pela Anti-Defamation League, cujo tema principal foi a divulgação da minissérie "Holocausto".

\footnotetext{
${ }^{69}$ Idem, p. 3.
} 
O historiador Peter Novick destacou o esforço das principais instituições judaicas dos Estados Unidos na promoção da minissérie apontando que estas mesmas organizações já estavam engajadas na divulgação e promoção da memória do Holocausto e a exibição do teledrama representou uma oportunidade que não poderia ser desperdiçada neste contexto. De acordo com Novick, o dia da estreia do teledrama foi denominado pelas instituições judaicas em seu diálogo com líderes civis e religiosos como "Domingo do Holocausto", com programações de séries de atividades em várias cidades do país. A Conferência Nacional de Cristãos e Judeus distribuiu estrelas amarelas para serem usadas no dia da estreia ${ }^{70}$. Ao mencionar esta estratégia de promoção da minissérie, Novick reforça o caráter comemorativo que envolveu a divulgação e a exibição do teledrama. Embora este esforço tenha sido ampliado para o público em geral, como já podemos observar nas sugestões dadas pelo rabino Marc. H Tanenbaum e na programação geral de divulgação pelas instituições judaicas, houve uma preocupação evidente em atingir diretamente a comunidade judaica norteamericana, questão que será aprofundada após a análise do documento audiovisual.

\footnotetext{
${ }^{70}$ NOVICK, op. cit., p. 210
} 


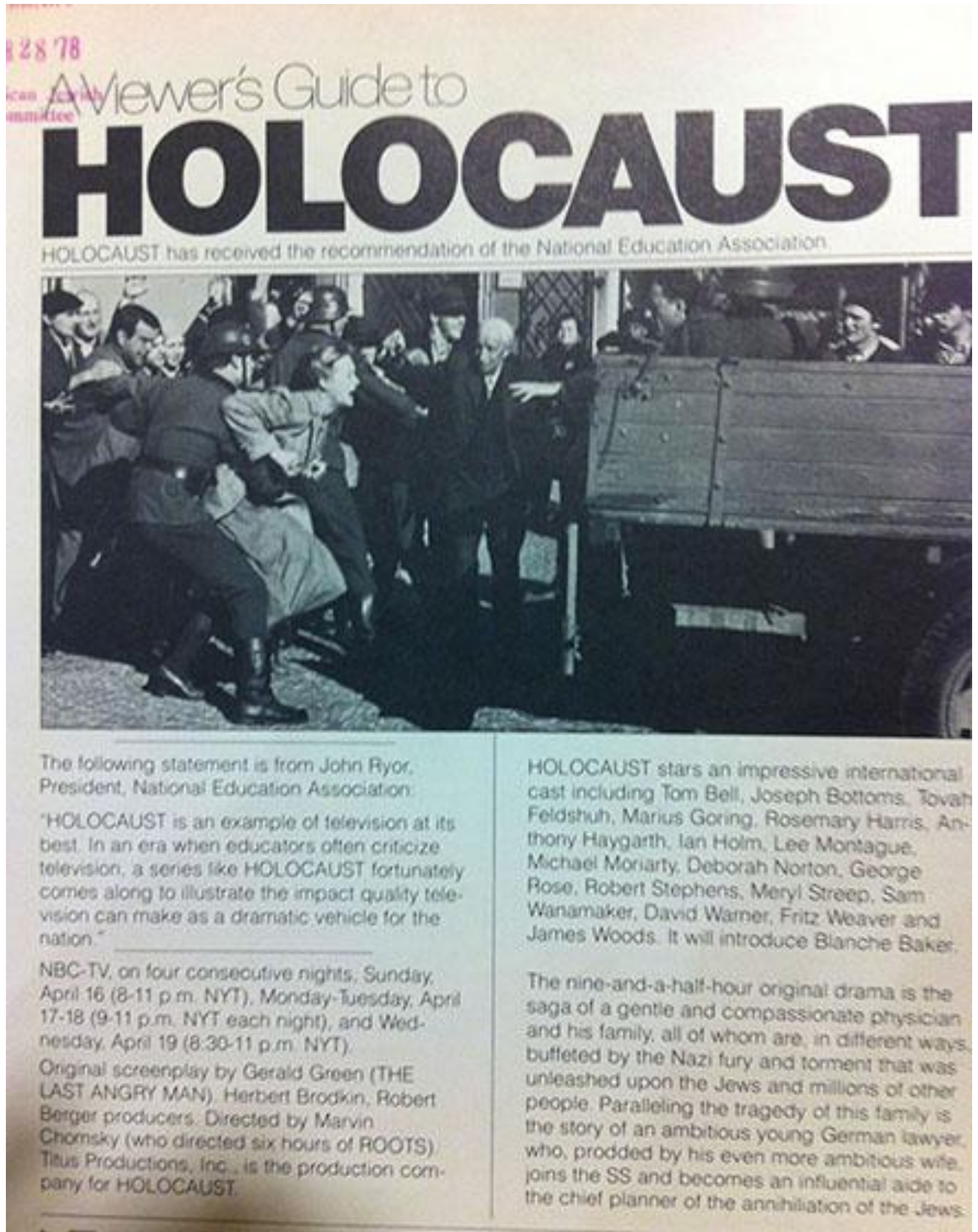

Figura 2 - Guia para o telespectador da minissérie preparado pelo American Jewish Committee com a recomendação da National Education Association. 


\subsection{Primeiro episódio: "The Gathering Darkness"}

O enredo de "Holocausto" tem início em 1935, dois anos após a chegada de Hitler ao poder e o estabelecimento do regime nazista. Embora a narrativa não deixe claro o período do ano, é possível notar que foi antes da promulgação das Leis de Nuremberg, já que a primeira cena da minissérie é a do casamento entre os personagens Karl Weiss e Inga Helms. A primeira imagem apresentada ao telespectador é a celebração do matrimônio nos jardins de um palacete alemão, ao som de típica música germânica executada com uma pequena orquestra em que se destaca a presença de acordeões. Há um contraste evidente entre o tom idílico do acompanhamento musical, as primeiras imagens de celebração matrimonial e a informação apresentada na tela revelando que os personagens estão em Berlim, 1935. O próprio título original do primeiro capítulo "The Gathering Darkness" aprofunda esse contraste, acentuando de alguma forma o sentido de uma presença maléfica que, embora já presente, pela evidência da data, ainda não parece claramente explícita, sobretudo pelo tom festivo da celebração do matrimônio.

Os traços mais característicos de alguns personagens presentes no evento já são diretamente apresentados ao telespectador nesta primeira cena. Karl Weiss, o jovem desenhista judeu, é um noivo tímido, cujo acanhamento ao beijar a noiva em público revela uma personalidade retraída e sensível. Inga Helms, a jovem ariana, introduz sua impetuosidade e tenacidade ao forçar o noivo a beijá-la e ao afirmar que terá como obrigação acostumá-lo a isso. Na sequência, Joseph Weiss, pai de Karl, faz um discurso e propõe um brinde aos recém-casados em uma atmosfera em que todos parecem felizes, com clara exceção de um personagem, amigo da família Helms, presente à cerimônia. Trata-se de Heinz Muller, membro do partido nazista (cuja filiação partidária ainda será revelada no andamento da cena) que observa a união das duas famílias ao lado de Hans, irmão de Inga e jovem soldado da Wermacht. As especulações de Heinz a respeito da identidade judaica da família Weiss são dirigidas a Hans, principalmente após o anúncio de Joseph de que seu irmão, Moses, veio de Varsóvia especialmente para a cerimônia. A simples presença de Moses dá a Heinz Muller a certeza de que o casamento celebra a união entre um judeu e uma ariana. Muller é apresentado ao 
telespectador como o primeiro vilão do enredo através de sua postura de falsa simpatia e de seu olhar desconfiado e inquisitivo em relação à família do noivo.

Os Helms são retratados como uma família modesta em relação aos Weiss (aparentemente Joseph é um médico conceituado na cidade), embora o próprio pai do noivo faça questão de pontuar que todos ali presentes são, acima de tudo, "bons berlinenses". Herr Helms declara o seu orgulho pelo casamento da filha, mencionado a esposa e o filho mais novo, Hans, um soldado servindo à vaterland. A presença de Hans faz com que Heinrich Palitz, avô materno de Karl, rememore seu orgulho de ter sido um oficial do exército alemão, tendo sido inclusive laureado com uma Cruz de Ferro pelo próprio Kaiser.

Tomado por um certo desconforto, Joseph Weiss desculpa-se com seu irmão Moses já que o a união de Karl e Inga não está sendo celebrada em um ritual judaico, mas em uma cerimônia civil. O irmão diz compreender e não se importar e Joseph acrescenta que a família ainda observa os feriados importantes para a crença judaica, como a Páscoa. Berta Weiss, mãe de Karl, demonstra estar feliz com o casamento do filho, embora seja possível notar uma evidente inquietação em seu comportamento cuja razão ainda não é possível decifrar.

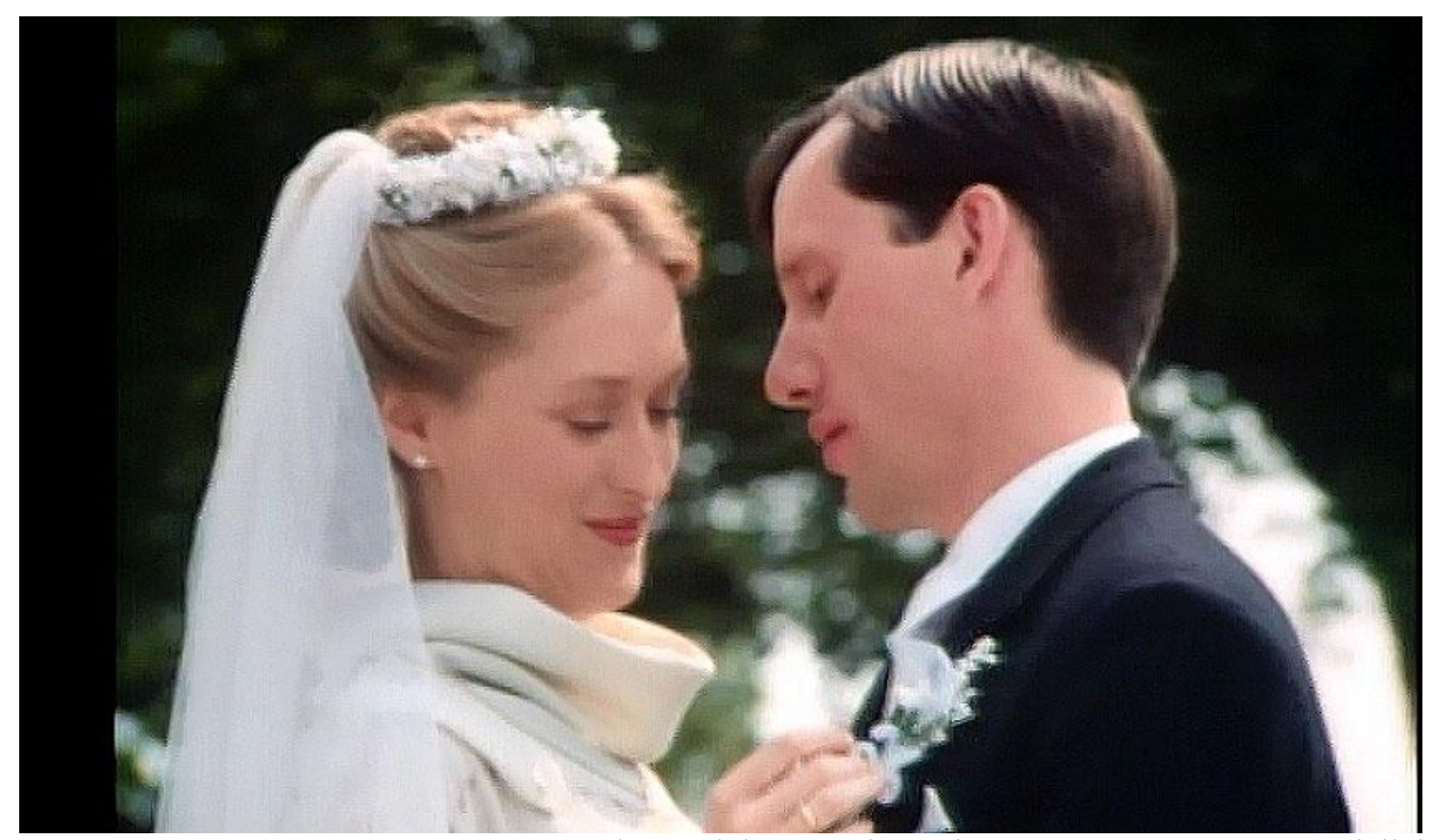

Figura 3. - Karl Weiss e Inga Helms, o casal central da trama de "Holocausto" em seu casamento civil de típica característica do cosmopolitismo burguês judaico-alemão 
A narrativa caracteriza os Weiss como uma típica família de judeus alemães assimilados, de hábitos cosmopolitas, completamente inserida no contexto social da Alemanha nos primeiros anos do nazismo. Como exceção das especulações a respeito da identidade étnica da família feita pelo próprio Heinz Muller e do pedido de desculpas de Joseph ao seu irmão Moses em razão do caráter civil da cerimônia, não há nenhum aspecto que indique diretamente que se trata de uma família judia. O próprio reforço de Joseph Weiss de que todos são ali "bons berlinenses" evidencia uma integração que, se não é plena, não parece incomodar a família. Entre os Helms e seus convidados, com a exceção de Heinz, não se nota um desconforto explícito com aquela união. É importante destacar que Hitler tornou-se chanceler em 30 de Janeiro de 1933, mais de dois anos antes da data em que o início da história e o casamento são apresentados.

A escolha por centrar a narrativa da minissérie na história de uma família de judeus assimilados na Berlim dos primeiros anos do nazismo revela a evidente necessidade de um elo de identificação com o público telespectador. Os Weiss podem ser comparados não só com uma típica família judia de classe média nos Estados Unidos, mas também, de maneira mais ampla com qualquer família de classe média norte-americana, em boa parte telespectadores do drama apresentado. Embora a própria exibição da minissérie seja um sintoma claro de afirmação de identidade, objeto principal desta análise, ter como protagonistas do teledrama uma família de judeus azkhenazim $^{71}$ do leste europeu reforçaria um traço de alienação que os produtores de "Holocausto" não estavam dispostos a arriscar. O roteirista Gerald Green, também autor do romance que acompanhou a exibição da minissérie, manifestou-se a esse respeito ao falar sobre esta decisão:

Eu queria uma verdadeira família alemã, o equivalente a judeus norteamericanos que se veem, antes de qualquer coisa, como norte-americanos. Não queríamos judeus do tipo "Um Violinista no Telhado", embora estes tenham sido as principais vítimas do Holocausto. Tínhamos medo de que eles

\footnotetext{
${ }^{71}$ Durante o período medieval os judeus europeus se dividiram em duas categorias principais: os judeus da península Ibérica e da Provença foram designados de Sefaradim e os que viviam na Alemanha e nos países da Europa Oriental que falavam íidiche chamavam-se Askhenazim. As duas categorias comunitárias acabaram desenvolvendo costumes e cerimônias religiosas diferenciadas. In: ENCICLOPEDIA JUDAICA. Rio de Janeiro: Editora Tradição, 1967, p. 52.

72 "Um Violinista no Telhado" (Fiddler on the Roof) é um musical em dois atos do compositor americano Jerry Bock. A obra, que se passa na Rússia czarista, em 1905, é baseada na peça "Tevye e suas Filhas", também conhecida como "Tevye, o Leiteiro, e outros Contos", de Sholem Aleichem. WHITFIELD, Stephen. Fiddling with Scholem Aleichem: a history of Fiddler on the Roof in: KUGELMASS, Jack. Key texts in american jewish culture. New Jersy: Rutgers University Press, 2003.
} 
pudessem invalidar o que estávamos tentando fazer: atrair uma grande audiência. $^{73}$

No que concerne ao público espectador judeu parece evidente um esforço de identificação e de proximidade com o núcleo familiar da narrativa. Em relação ao público mais amplo, não se buscava uma identificação direta, mas despertar a simpatia destes com o destino da família Weiss. Pode-se afirmar então que, para os não judeus, o papel de espectador do drama os posiciona como as testemunhas da política de extermínio nazista. Assim, como sugere Judith Doneson: "A moral, é claro, está evidente: a testemunha - o vizinho - é com frequência tão culpado quanto o criminoso, seja na Alemanha nazista ou na América contemporânea." 74

Voltemos à cena do casamento, que marca o início do enredo. Disposto a aconselhar a família a respeito de uma união matrimonial fadada à anulação, Heinz Muller lamenta para Herr Helms: "É uma pena que o casamento não tenha sido adiado por alguns meses”. O pai de Inga demonstra preocupação com a fala de seu amigo nazista que esclarece afirmando que partido pretende proibir casamentos inter-raciais. $\mathrm{O}$ caráter maléfico de Heinz Muller é reforçado por sua ambivalência ao afirmar em seguida que não há motivos para preocupação e que talvez tudo termine bem.

É Heinrich Palitz, ao rememorar o seu passado de herói de guerra alemão, que desnuda a identidade nazista de Heinz Muller. Ao exaltar as forças armadas de seu tempo e o marechal von Hindenburg, Palitz afirma que os generais é quem deveriam cuidar da Alemanha e enfrentar esta "multidão". Muller pergunta a que multidão ele se refere ao que Palitz responde: "posso ver o que você está usando", revelando o broche nazista oculto em seu casaco. "Basta um punhado de militares para fazê-los correr", conclui Palitz. Este primeiro momento de tensão explicita os traços de identidade (judia e nazista) que pareciam até aquele momento subsumidas na celebração do matrimônio. A discussão política é interrompida quando Inga sugere que todos cantem para celebrar o matrimônio. Joseph sugere Lorelei, clássica canção alemã baseada nos versos do poeta Heinrich Heine, banida pela política nazista e por essa razão proibida de ser executada.

\footnotetext{
${ }^{73}$ GREEN, Gerald apud DONESON, op. cit., p. 151. (Trad. do autor). No original: "I wanted a real German Family, the equivalent of American Jews who think of themselves first as Americans. We didn't want to do Fiddler on the Roof Jews, although they were prime victims of the Holocaust. We were afraid they would vitiate what we were trying to do - appeal to a broad audience."

${ }^{74}$ Idem, p. 151. No original: "The moral, of course, is evident: the bystander - the neighbor - is often as guilty as is the perpetrator, be it in Nazi Germany or contemporary America."
} 
O acordeonista adverte os convidados a respeito da proibição, mas Berta Weiss solicita que tal medida seja ignorada pontuando que os versos de Heine são adequados para a ocasião. Heinz Muller apenas acompanha o momento de transgressão à lei nazista.

A sombra nazista sobre o casamento de Karl e Inga revela-se totalmente no final da cena. Enquanto os convidados cantam a Lorelei, Rudi Weiss e sua irmã Hannah brincam com uma bola de futebol que acidentalmente ultrapassa os limites do jardim aproximando-se de um grupo de membros das Tropas de Assalto. Os personagens desta cena evocam uma típica imagem da organização paramilitar com seus membros vestidos de uniforme pardo e braçadeiras nazistas. Um dos membros da milícia devolve a bola com displicência, e Rudi os observa fixamente revelando a consciência sobre o perigo à espreita. A percepção de Rudi a respeito deste perigo contrasta com o tom festivo nos limites do jardim onde ocorre o casamento, reforçando visualmente o alheamento geral da família a respeito da ameaça que os cerca.

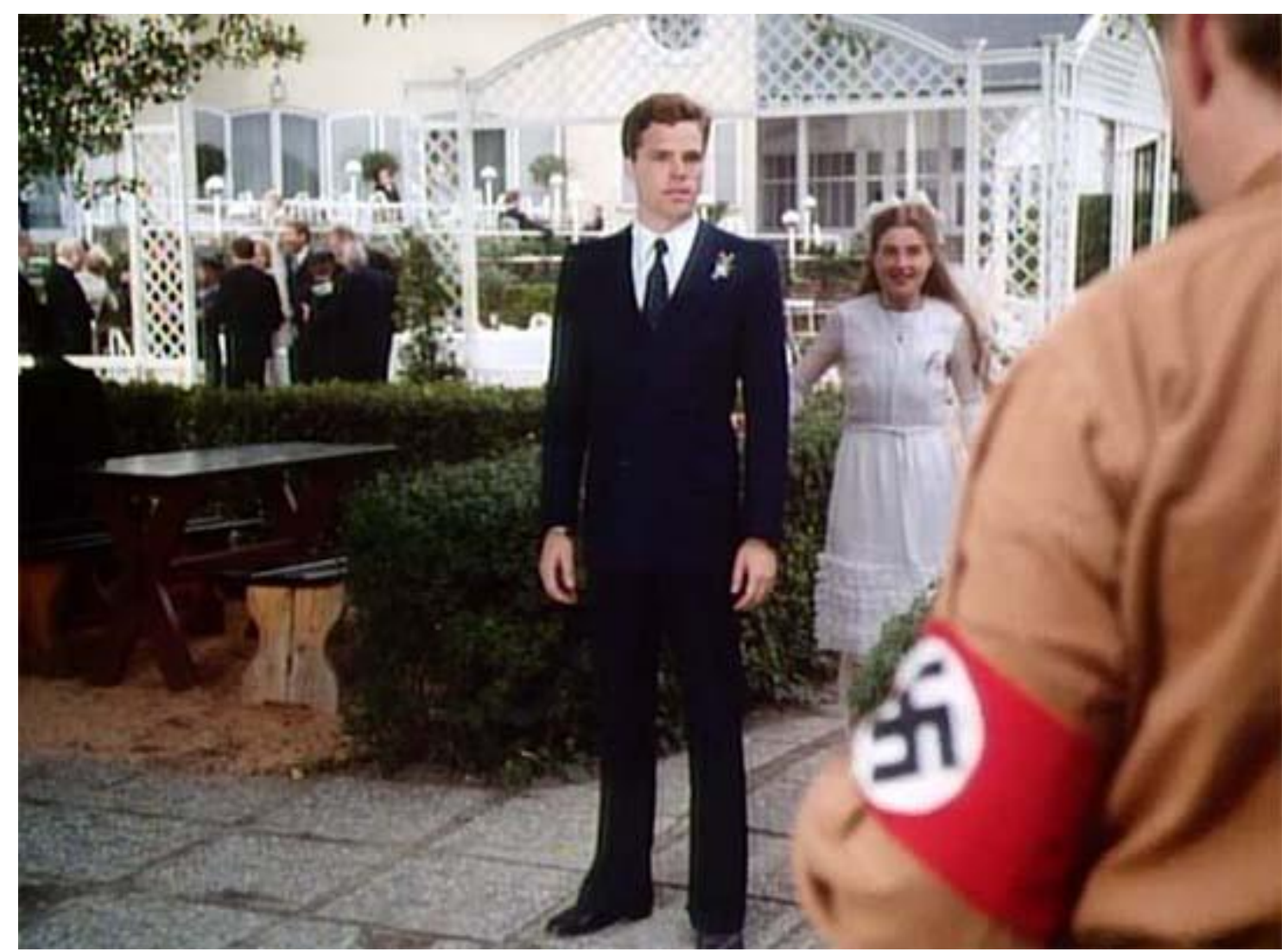

Figura 4 - Rudi Weiss prenuncia sua trajetória heroica ao antever o perigo da ameaça nazista que ronda a celebração de matrimônio de seu irmão Karl 
O enredo de "Holocausto" está centrado em três núcleos familiares. Dois deles são apresentados no casamento que dá início à história. A terceira família, e que de alguma maneira forma um paralelismo antagônico com o clã protagonista, é formada pelo advogado Erik Dorf, sua esposa Marta e seus dois filhos. A narrativa apresenta o casal em uma consulta médica com Joseph Weiss, que diagnostica Marta com um problema cardíaco e anemia. A doença de alguma forma está relacionada com as precárias condições financeiras do jovem casal, reveladas pela própria Marta que afirma não ter condições de contratar uma empregada quando o médico prescreve repouso. Ao final da consulta, Joseph afirma ter conhecido um padeiro de sobrenome Dorf que ao final descobre-se ser o pai de Erik, morto após arruinar-se durante a depressão econômica alemã.

Erik Dorf caracteriza o típico cidadão alemão atingido pela crise econômica da República de Weimar. Desempregado e sem condições de sustentar a família, vive da ajuda dos pais da esposa e do próprio Joseph, que não cobra as consultas médicas até que ele consiga um emprego. De personalidade pouco ambiciosa, não parece dar crédito às próprias habilidades profissionais considerando-se um fracassado. É Marta quem o incentiva e estimula, valorizando seu talento e sugerindo a um tio que o recomende a uma posição nos quadros do partido nazista, como assistente de Reinhard Heydrich. Resistindo inicialmente a agendar uma entrevista com o eminente membro do partido por ser filho de um socialista e avesso à política, Dorf termina por aceitar as sugestões da esposa que de certa forma o chantageia em nome do bem-estar da família.

Reinhard Heydrich é o primeiro de uma série de personagens históricos a ser apresentado ao telespectador. Tais figuras históricas do nazismo e do Holocausto acompanham alguns dos personagens fictícios nos quatro capítulos da minissérie, quase sempre interagindo com estes nos momentos em que sua atuação em determinado fato histórico é apresentada. Na sequência abaixo vemos um trecho da entrevista de emprego de Dorf com Heydrich, em que alguns elementos clássicos das relações dos membros do partido são revelados ao público:

HEYDRICH: Dorf, Erik, 24 anos, natural de Berlim, graduado pela Universidade da Alemanha, sem filiação ao partido.

DORF: Pois é, até o momento não. 
HEYDRICH: E qual o seu interesse?

DORF: Preciso de trabalho

HEYDRICH: Gosto de sua sinceridade. Você não tem ideia de quantas mentiras tenho que ouvir. Hipócritas, bajuladores, morrendo de amores pelo partido, pelo Führer, pelo Reich. É um alívio encontrar uma pessoa que apenas procura trabalho

DORF: Eu respeito o partido e admiro o trabalho do Führer

HEYDRICH: Advogado, boa educação. Não exerce a profissão porque algum judeu ou socialista lhe tomou o emprego

DORF: Eu não uso tais desculpas

HEYDRICH: Por que não? Conhecemos nossos inimigos. O que sabe sobre nós?

DORF: Que são uma organização social e política responsável pela segurança interna e externa do Estado. Confesso que não sei a diferença entre SS, SD e Gestapo

HEYDRICH: Nem nós. Mas não importa, controlo as três. Com a autorização do Reich, do Führer Hitler, é claro. Qual a sua opinião sobre os judeus?

DORF: Sou neutro

HEYDRICH: Gosto de sua honestidade

DORF: Espero que não me ache ingênuo

HEYDRICH: Nada disso. O fanatismo dos verdadeiros crentes é admirável mas às vezes é melhor ser neutro, analítico, frio. Porque a conspiração judaica mundial e o complô bolchevique e capitalista para dividir a Alemanha é algo frio e analítico. Envenenamento racial dos judeus, infiltração em nossa vida nacional, traição dos ideais da Alemanha, é tudo repugnante, Dorf.

DORF: Conheço os ideais do Führer

HEYDRICH: Então você sabe da importância de nossa política racial. É a ideia central de nosso programa. Resolveremos a maioria dos problemas econômicos, militares, governamentais, simplesmente atacando os judeus. 
DORF: Sim, se todos concordam.

HEYDRICH: Um futuro emocionante.

Aprovado por Heydrich para ser seu assistente, Erik Dorf é o personagem que reúne as características do funcionário carreirista e zeloso do partido, que obtém uma rápida ascensão em seus quadros ao adaptar-se facilmente à rotina burocrática que executará a perseguição aos opositores do regime e o extermínio da população judaica. O diálogo em destaque faz menção às características de outra figura histórica, Adolf Eichmann, cujo perfil se tornou famoso a partir da obra clássica de Hannah Arendt, “Eichmann em Jerusalém". Embora este personagem histórico também apareça na minissérie e interaja com o próprio Dorf, o trecho em que este se refere à sua neutralidade em relação aos judeus remete ao próprio depoimento de Eichmann em seu julgamento em Jerusalém, descrito por Hannah Arendt em seu relato: "pessoalmente (eu) não tinha ódio aos judeus, pois toda a minha formação por parte de pai e mãe foi estritamente cristã; minha mãe, devido aos seus parentes judeus, tinha opiniões diferentes das que eram correntes nos círculos da $\mathrm{SS}^{\text {"75. }}$.

De fato, Eric Dorf sumariza em seu personagem todo o aparato estatal nazista que provocará a dissolução da família Weiss e a concretização de seu trágico destino. Seu papel como assistente de Heydrich permite que o telespectador tenha acesso às decisões tomadas nos altos círculos do Terceiro Reich. Sua profissão de advogado também revela o ambiente de inversão jurídica durante o governo nazista. Ao despedirse de Heydrich em sua entrevista de emprego e fazer a saudação nazista do Sig Heil de maneira espontânea, Erik Dorf sela o seu destino de nazista e principal vilão da história.

Dorf se tornará o assistente fiel e dedicado que, na narrativa de alguma forma influenciará em algumas decisões de Reinhard Heydrich em relação à política do Reich para com os judeus. Sua esposa Marta é o motor que o tornará cada vez mais ligado às engrenagens do regime e à proximidade das decisões relacionadas com a Solução Final. Se algumas vezes ele hesita em relação aos serviços que deve prestar ou ao antissemitismo oficial, é Marta quem o reorienta e direciona lembrando-o dos benefícios obtidos em seu cargo no governo ou dos problemas decorrentes de alguma suposta simpatia pelos judeus. Tal hesitação, que tem raiz na sua anterior relação com judeus

\footnotetext{
${ }^{75}$ ARENDT, Hannah. Eichmann em Jerusalém: um relato sobre a banalidade do mal. São Paulo: Companhia das Letras, 1999, p. 41
} 
como Joseph Weiss e na lembrança de seu pai socialista, é completamente anulada no decorrer da história.

Os Dorf também são representados como o modelo exemplar da família ariana, frequentemente divulgada pelo ministério de propaganda dirigido por Joseph Goebels, com seus traços nórdicos, a esposa exemplar que se dedica às funções domésticas, o marido zeloso, envolvido em seus deveres para com a pátria e o jovem filho membro da juventude hitlerista. A ascensão social meteórica dos Dorf, de alemães arruinados a modelo exemplar de família ariana é paralela à derrocada dos Weiss. Há no entanto um personagem da família Dorf que surge no decorrer da trama representando o cidadão comum alemão que, tendo apoiado a chegada de Hitler ao poder e celebrado as vitórias econômicas do regime, percebe pouco a pouco a violência da repressão política e a brutalidade da perseguição aos judeus. Trata-se de Kurt Dorf, tio de Erik, um empresário do ramo de pavimentação que se beneficia do expansionismo econômico nazista mas que, ao se dar conta dos crimes cometidos, tem a consciência atormentada. Seus questionamentos sobre as atividades do sobrinho envolvendo a perseguição aos judeus funcionam como uma espécie de lembrete a Erik do caráter e da honestidade alemãs perdidas no Terceiro Reich.

Do momento em que Erik Dorf torna-se oficial assistente de Heydrich há um corte temporal de 3 anos. Ao som de uma música de Mozart ao piano, supostamente tocado por Berta e Hannah Weiss, imagens de arquivo apresentam os suntuosos desfiles militares nazistas, Hitler nas Olímpiadas de Berlim em 1936, o Führer passando em revista às tropas ou desfilando em carro aberto, fazendo a clássico gesto da saudação nazista. O reencontro de Joseph Weiss com Erik Dorf, agora um tenente a serviço da Gestapo, ocorre em 1938, após esse lapso de tempo. A visita de Dorf - em uma clara posição de superioridade - é apenas para adverti-lo sobre a proibição governamental, ignorada pelo médico, de tratar arianos em sua clínica. Podemos perceber que a situação dos judeus deteriorou-se drasticamente no período, pela reação do médico ao recebê$10^{76}$. Dorf o aconselha a deixar o país informando que as coisas devem piorar para os judeus em um futuro próximo. Joseph alega que não pode partir por razões

\footnotetext{
${ }^{76}$ Como afirma o cientista político Daniel Jonah Goldhagen, “as leis de Nuremberg tornaram explícita e em grande parte detalhada a eliminação dos judeus da existência civil e social na Alemanha, avançando bastante no sentido de separá-los de forma irrevogável" in GOLDHAGEN, Daniel Jonah. Os carrascos voluntários de Hitler: o povo alemão e o Holocausto. São Paulo, Companhia das Letras, 1997, p. 110.
} 
humanitárias, já que a maioria dos médicos judeus já deixou a Alemanha e não há médicos que possam dar assistência aos que ficaram.
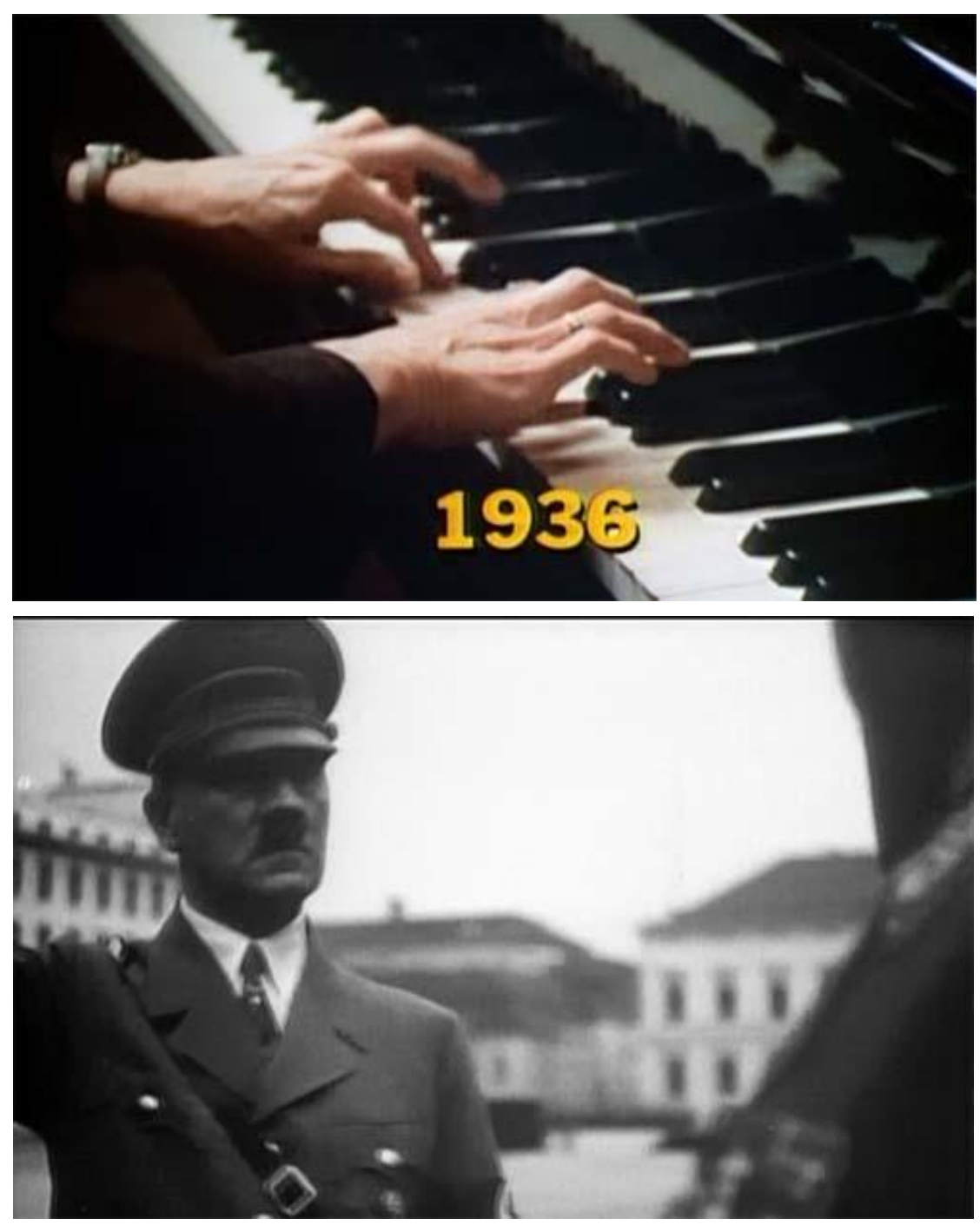

Figura 5 - A música do piano tocada por Berta Weiss acompanha a passagem do tempo com imagens de arquivo que anunciam a radicalização do Terceiro Reich e a deterioração da vida dos judeus alemães.

Neste diálogo é também o próprio Joseph quem revela que os judeus já perderam a cidadania e os direitos legais, não podem ser tratados em hospitais e podem ter os bens confiscados. Erik Dorf diz a Joseph que este não deve contar com sua ajuda, e o médico pergunta "nem sequer em nome de nossa antiga amizade?" ao que o tenente da Gestapo responde: "não adianta suplicar. Vocês têm outros recursos. Vão embora". Já sozinho em seu consultório, o médico murmura: "Não é tão simples ir embora". A minissérie introduz aqui a questão da emigração dos judeus-alemães no Terceiro Reich. Após a 
visita de Erik, Joseph propõe a Berta deixarem o país, algo que, segundo ele, deveria ter sido feito após o casamento de Karl, três anos atrás. Berta se responsabiliza pela decisão que a família tomou ao permanecer, alegando que "este é o meu país, tanto quanto deles e não devemos temer estes bárbaros". Ela segue sua crença em um momento de crise passageira, alegando "Nós sobreviveremos. Esta é a pátria de Beethoven, Schiller e Mozart".

No decorrer do capítulo o esquema melodramático vai se revelando por meio dos episódios em que a perseguição à família Weiss torna-se mais acentuada. Os traços de bondade e maldade das personagens são apresentados de maneira enfática em relação a como provocam ou reagem aos episódios de perseguição representados na narrativa. Cada membro da família tem um traço positivo destacado, e tal característica terá relação com sua trajetória no enredo. Inga Helms é o único personagem ariano de qualidades positivas a sobreviver à guerra mantendo seus valores e a nobreza de caráter, posicionando-se claramente em defesa da família do marido, mesmo que isso signifique um considerável risco. Karl personifica o artista sensível que se torna vítima injustiçada e, uma vez encarcerado, tenta se adaptar à condição de prisioneiro. Joseph é o pai de família sensato que, mesmo diante da deterioração da situação familiar, procura manter algum otimismo e crença no futuro. Berta, recusando-se a abrir mão de uma nacionalidade e de sua herança cultural alemã negada pela ideologia nazista, dá voz ao cosmopolitismo judeu-alemão. Seus pais e sua filha Hannah representam a inocência daqueles que acabam se tornando as primeiras vítimas fatais do regime nazista por não suportá-lo. Entre todos, Rudi é o único que, antevendo o perigo iminente, se propõe a resistir e a lutar. Seu perfil atlético está em direta conexão com seu caráter heroico que se manifesta precocemente no enredo, marcando sua atuação futura na narrativa do teledrama e o significado de sua sobrevivência.

Em sua análise a respeito do roteiro da minissérie o rabino Marc Tanenbaum revela um desconforto com a caracterização de passividade da família Weiss diante do iminente perigo nazista. $\mathrm{O}$ religioso manifestou apreensão pelo fato de que o primeiro capítulo apresentasse judeus submissos e acomodados diante de nazistas e protonazistas com características até positivas. Tal situação poderia, em seu entendimento, deixar uma impressão duradoura no público espectador ${ }^{77}$. O fato é que o roteiro de

\footnotetext{
${ }^{77}$ TANENBAUM, op. cit. p. 4
} 
Gerald Green reforçou a inocência e até certa passividade dos Weiss com o objetivo de iniciar a trajetória destes em direção à sua herança judaica obliterada pela assimilação. Aqui, tal assimilação é sinônimo de certa passividade e ingenuidade.

Os alemães arianos, com raras exceções, na maioria das vezes são caracterizados como nazistas atuantes, simpatizantes do regime ou simplesmente testemunhas desinteressadas das atrocidades que claramente escolhem não se envolver na defesa de judeus perseguidos. Personagens fictícios ligados ao aparato estatal nazista como Erik Dorf e Heinz Muller, evidentemente, ocupam o lugar principal da vilania, por suas características repulsivas, sua perversidade, violência, fanatismo e frieza diante dos massacres. Os simpatizantes do regime ocupam um segundo lugar na escala negativa do enredo por suas atitudes dissimuladas, sua deslealdade e seu oportunismo. Encaixam-se neste perfil os familiares de Inga, como seus pais e seu irmão Hans, além de Marta Dorf. As testemunhas arianas aparecem de forma anônima em algumas cenas, quase sempre presenciando atos de vandalismo e perseguição sem qualquer reação de entusiasmo ou compaixão, mas de alguma forma revelando sua cumplicidade exatamente pela indiferença com relação ao cenário que os rodeia. Como já apontamos, o espectador não-judeu do teledrama acaba de certa forma identificado com estas mesmas testemunhas.

Entre os oficiais nazistas ou membros do partido não há qualquer traço de nuance ou incerteza, porque estes personificam o mal absoluto no imaginário público sobre o tema. Qualquer traço de indecisão ou arrependimento por parte destes personagens poderia confundir e ameaçar o caráter didático e as marcações definidas entre o bem e o mal, essenciais no formato melodramático, que a minissérie visava alcançar em sua representação.

O desafio de apresentar 10 anos do Terceiro Reich para o público televisivo de uma grande emissora tendo como pano de fundo um drama familiar em que os personagens percorrem os principais eventos da história do nazismo e do Holocausto em diferentes cenários, incorre em uma inevitável simplificação. Não há espaço para aprofundamentos mais complexos sobre o pano de fundo histórico e a variedade de causas e relações entre tais eventos. Os produtores da minissérie procuraram reforçar o senso comum a respeito dos eventos retratados, incluindo neles os elementos de um discurso de memória que procuraram recuperar. Por conta disso, um didatismo muitas 
vezes pueril, perceptível na fala empostada de alguns personagens, permeia todo o enredo. Não se tratou apenas de retratar o período nazista, mas de explicar, com um inconfundível estilo pedagógico, cada um de seus principais eventos, suas causas e eventuais consequências.

O primeiro destes eventos apresentado ao público é a Noite dos Cristais, que ocorre exatamente no momento em que a família Weiss decide se deve ou não deixar a Alemanha. O prazo para esta decisão esgotou-se e a emigração tornou-se quase impossível, o que permite à narrativa tanto dar início à sua trajetória de perseguições e sofrimento quanto apresentar o quadro geral de restrição à entrada de imigrantes judeus nos vários países do mundo. Em uma cena de jantar em que os membros da família decidem seu destino, a menção às dificuldades de emigração enfatiza a pouca disposição dos países de receber refugiados judeus:

INGA: Meu amigo ferroviário disse que pode comprar a saída de vocês, mas que vai custar muito dinheiro.

JOSEPH: Podemos arrumar o dinheiro. Qual destino ele sugeriu?

INGA: Ele não sugeriu.

KARL: Já não há lugares para ir, papai.

JOSEPH: Tem certeza disso? França, talvez Suíça?

KARL: Os suíços estão deportando os judeus, os franceses também.

RUDI: Ninguém nos quer.

KARL: É verdade, ouvi um boato de que os Estados Unidos não querem deixar mais judeus entrarem para não encher o contingente alemão. Alguns já estão retornando.

HANNAH: Podemos ficar! Estamos juntos. Não é verdade, mamãe?

BERTA: Claro, Hannah.

INGA: Estou tão envergonhada. E se eu falasse outra vez com esse homem?

KARL: Não adianta. Nós esperamos demais. 
O telespectador é apresentado neste momento à questão da falta de apoio aos judeus por parte dos países estrangeiros e da parcial responsabilidade destes no destino sofrido pelos judeus posteriormente. O diálogo segue com Joseph sugerindo outras opções possíveis até ser interrompido por Berta:

BERTA: Não iremos a lugar nenhum. Pelo menos por enquanto.

RUDI: Mamãe sempre decide.

HANNAH: Talvez porque sempre tenha razão

BERTA: Hitler tem a Tchecoslováquia, tem a Áustria, o que mais ele quer? Já tem bastante para digerir toda essa torta austríaca e toda essa cerveja tcheca.

RUDI: Você realmente acredita nisso?

BERTA: Ele é um político. Todo ódio contra os judeus é político. Assim que conseguir o que quer ele se esquecerá de nós.

JOSEPH: Sua mãe tem razão. Alguns não estão contra nós, é só política.

BERTA: Meu pai disse que os generais não concordam com o que está acontecendo. Essas coisas terríveis.

JOSEPH: Sim, creio que podemos ser otimistas.

A insistência de Berta em permanecer na Alemanha, embora seja também resultado de um conformismo não assumido dado à gravidade da situação e a um apego perseverante à nacionalidade alemã, está em parte baseada na reação dos próprios judeus em relação ao antissemitismo histórico. A percepção de que, de tempos em tempos e de maneira transitória, o ódio aos judeus se acentua - principalmente em sua utilização como arma política - é apontada como uma das causas da falência dos judeus em perceber o perigo que corriam sob o Terceiro Reich. A narrativa da minissérie irá demonstrar nos episódios seguintes que Berta estava errada e o antissemitismo nazista alcançará um grau de crueldade até então desconhecido pela população judaica concretizando um plano de aniquilação inédito.

A disposição de Joseph Weiss ao otimismo dura pouco pois na mesma noite em que a família discute seu destino, Herschel Grynspan, um jovem judeu de origem 
polonesa, assassina em Paris o diplomata alemão Ernst Von Rath ${ }^{78}$. Um locutor de rádio anuncia a notícia, pontuando que a morte do diplomata foi "uma ação covarde e criminosa da conspiração judaica internacional". O locutor acrescenta que demonstrações espontâneas de antissemitismo tiveram início na mesma noite e que "o povo alemão se levantará para vingar o assassinato de Von Rath”. Rudi elogia a ação solitária de Grynspan quando uma pedra atinge a vidraça do apartamento dos Weiss e vozes de uma multidão enfurecida repentinamente surgem nas ruas.

A Noite dos Cristais acaba sendo para Erik Dorf uma oportunidade de aumentar sua influência sobre Heydrich. Como o ataque a lojas e propriedades de judeus foi incitado pelo próprio ministro da propaganda do Reich, Joseph Goebbels, o oficial nazista preocupa-se com a opinião pública mundial a respeito dos distúrbios e do envolvimento do governo no episódio. Erik sugere que os homens do partido e simpatizantes façam os ataques em roupas civis, sem uniformes da Gestapo, SS ou SA, dando a entender que se trata da "justa ira do povo alemão se revoltando contra os assassinos". O jovem oficial sugere um acordo com a polícia para não interferir nos tumultos. Heydrich elogia Erik destacando as brilhantes ideias de sua "excelente mente jurídica”. Pode-se perceber aqui uma clara divisão entre o frenesi antissemita e descontrolado (representado pelo incitamento de Goebbels para a vingança do povo ariano contra o assassinato de Von Rath por um jovem judeu) e as decisões metódicas dos burocratas do regime.

Esta é a primeira cena mostrando a intersecção entre a ficção e o fato histórico ao encenar que algumas medidas do governo nazista em relação aos judeus na verdade foram fruto das sugestões e da influência de um jovem advogado inteligente e carreirista que, manipulado por sua esposa, torna-se o cérebro das maiores atrocidades cometidas contra a população judaica europeia durante o Terceiro Reich.

\footnotetext{
${ }^{78}$ Von Rath era primeiro secretário na embaixada alemã em Paris. Revoltado com a situação dos judeus expulsos da Alemanha, grupo do qual fazia parte sua família, o jovem Herschel Grynszpan comprou um revólver e, ao ser encaminhado ao escritório do diplomata, atirou e o feriu mortalmente. FRIEDLÄNDER, Saul. A Alemanha nazista e os judeus: Vol. I, os anos da perseguição, 1933-1939. São Paulo: Perspectiva, 2012, p. 345.
} 

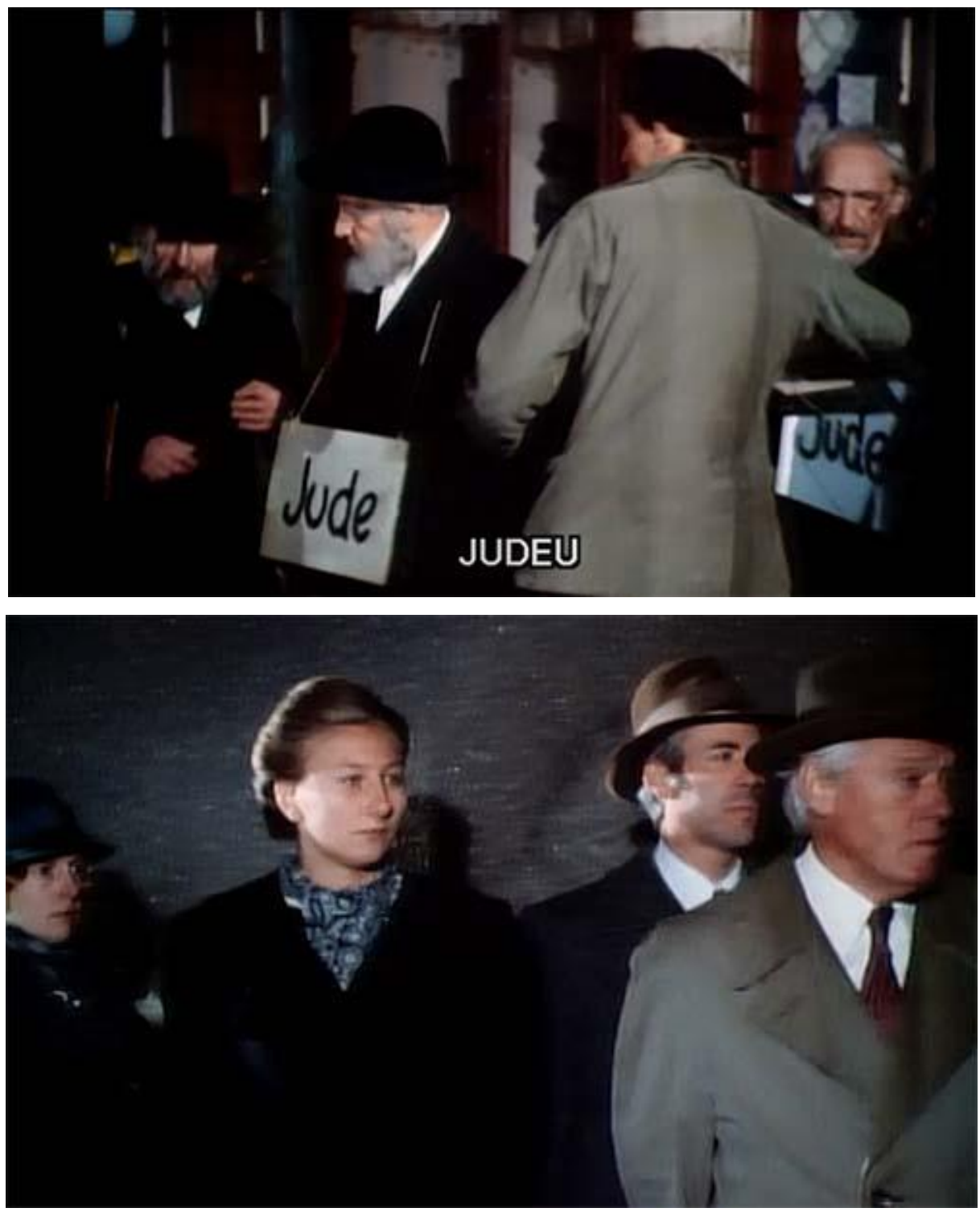

Figura 6 - Judeus berlinenses são atacados na Noite dos Cristais sob o olhar impassível das testemunhas arianas. O teledrama procurou colocar o telespectador na mesma posição destas testemunhas.

As principais vítimas da família Weiss durante a Kristallnacht são os pais de Berta. A livraria de Heinrich Palitz é atacada por um grupo de homens em trajes civis. Entre eles está Heinz Muller, o convidado nazista a quem o espectador já havia sido apresentado no casamento de Karl e Inga, que se aproveita do momento para obter sua revanche pelo tratamento recebido pelo velho Palitz no casamento. Os volumes de sua livraria são atirados na rua e queimados, Como sugerido por Erick, a polícia acompanha tudo sem interferir e os cidadãos de Berlim testemunham os ataques de maneira impassível. Heinz Muller e seu grupo agridem Heinrich Weiss violentamente e penduram em seu pescoço uma placa com a identificação "judeu", obrigando-o a marchar tocando um tambor pelas ruas do bairro. 
Esta cena reúne em um mesmo episódio três eventos famosos da política nazista na Alemanha antes da guerra: os ataques da Kristallnacht propriamente ditos, os famosos autos-de-fé contra obras de intelectuais não alinhados ao regime ou contra o que se considerava "literatura degenerada" e a execração pública de judeus por parte de membros do partido que aqui, conforme a própria narrativa aponta, não aparecem claramente identificados.

Rudi, contrariando as ordens de Joseph e Berta e arriscando-se nas ruas tumultuadas, resgata o avô das mãos do grupo de arruaceiros liberados por Heinz Muller. Entre eles também está Hans Helms, irmão de Inga. A presença dos dois personagens no grupo os posiciona agora de maneira mais clara na esfera da vilania, e o fato de estarem em trajes civis reforça em ambos o caráter de falsidade e dissimulação que os acompanhará durante toda a narrativa. Na sequência, Heydrich comemora os resultados dos ataques, embriagando-se ao som de Richard Wagner, exemplo nazista de superioridade musical ariana. Erik Dorf traz ao oficial os relatórios das ações executadas, destacando o número de mortos, as 800 sinagogas incendiadas, as mais de 30 mil pessoas presas e tímida reação da comunidade internacional. Neste momento, em um diálogo de entonação claramente didática, Erik aponta que a imprensa denominou o episódio como Noite dos Cristais. Dorf acrescenta que poucos governos defenderam os judeus atacados e que "a perseguição aos judeus é sempre bem vista".

Este momento marca o início da desintegração da família Weiss. Karl e Inga, o par romântico da trama na arriscada situação de um casamento misto entre um judeu e uma ariana, têm a sua relativa paz conjugal terminada com a prisão de Karl. Sem acusação formal, hábito comum nas abordagens nazistas a judeus, Karl é intimado pela Gestapo a um interrogatório de rotina. Inga o acompanha ciente de que tais depoimentos são apenas uma desculpa para a detenção e o desaparecimento. Aqui mais uma vez a deterioração das condições de vida da família Weiss é paralela à total ausência de solidariedade por parte de seus antigos amigos arianos. Inga solicita a sua mãe que fale com seu irmão Hans, soldado do exército, ou com amigos da família com influência nos círculos burocráticos do governo, para interceder pela libertação de Karl. Frau Helms recusa-se a atender ao pedido da filha alegando que isso desgraçaria a família.

Surpreendido pela prisão do filho, Joseph Weiss procura Erik Dorf, seu único contato na SS que, como se sabe, lhe devia favores. Embora Dorf tenha ordenado que 
não o procurasse para pedir ajuda, o médico implora para que ele interceda na libertação de Karl. A resposta negativa de Erik a este pedido é reforçada pela constante influência de Marta em suas decisões. A justificativa final é a de que ele não pode arriscar a carreira ajudando judeus.

Imediatamente após a prisão de Karl, Joseph recebe outro golpe. Oficiais do Departamento de Imigração invadem seu consultório e entregam a ele uma ordem de deportação. O médico deve deixar o país na manhã seguinte, levando apenas uma mala e comida para um dia. Joseph é o único membro da família a ser deportado sem detenção e representa neste episódio os milhares de judeus estrangeiros que haviam se estabelecido na Alemanha antes da ascensão de Hitler e que repentinamente perderam a cidadania ou o visto de permanência e foram expulsos do país. Sua deportação também inicia a trajetória dos membros da família Weiss em direção ao leste da Europa.

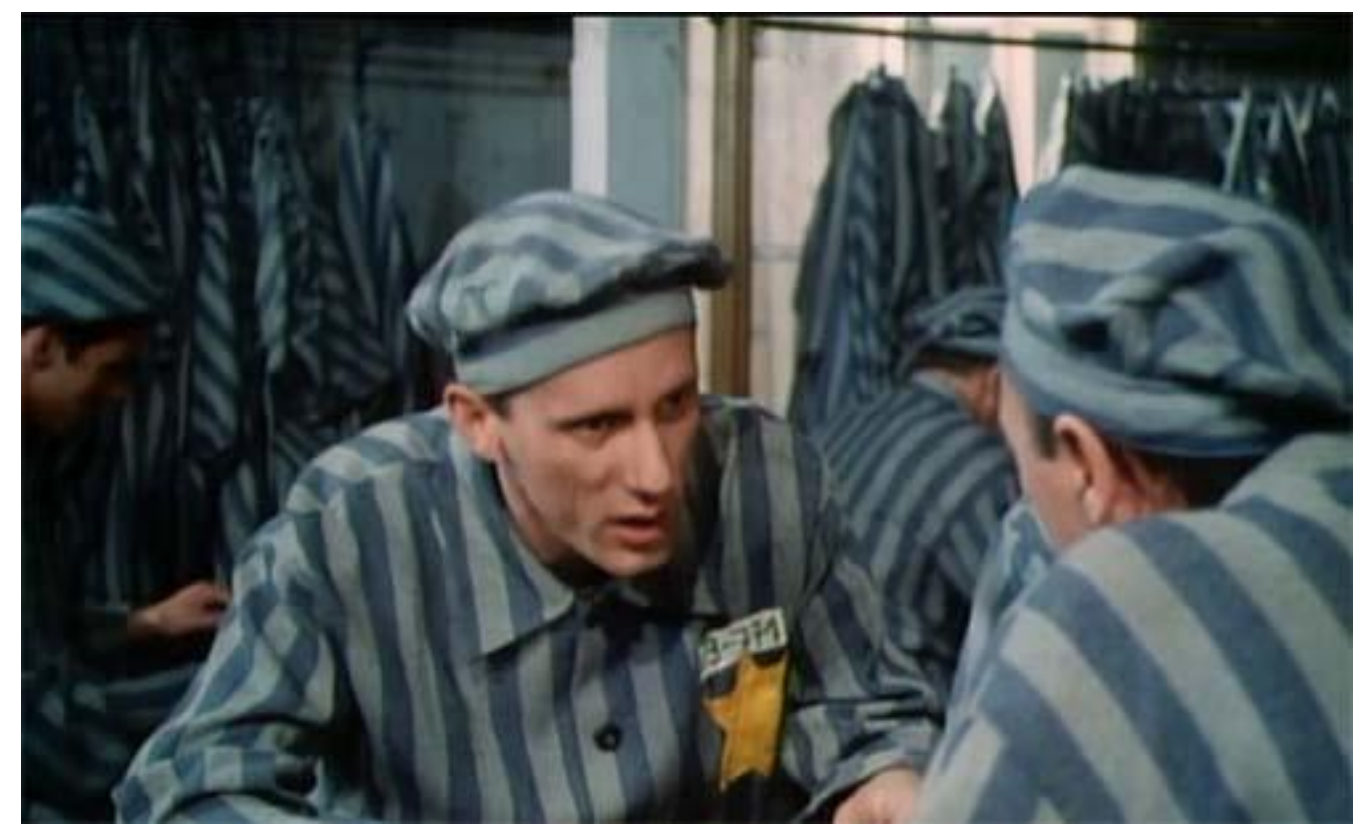

Figura 7 - Karl Weiss, nesta cena com o uniforme listado de prisioneiro, é o personagem que possibilita o mergulho do telespectador na rotina do universo dos campos de concentração e extermínio.

A prisão de Karl abre pela primeira vez ao telespectador os aspectos do universo concentracionário. O jovem pintor é levado para Buchenwald, e o tratamento cruel, a violência e as humilhações aplicadas em prisioneiros judeus são apresentados já em sua chegada ao local. Ao não entender este novo universo e ao mesmo tempo tentar adaptar- 
se a ele Karl sofre as consequências. Sua prisão sob uma falsa acusação, a violência extrema sofrida por ele ao tentar compreender o que se passa e seu aspecto frágil o identificam com as centenas de sobreviventes que relataram os aspectos brutais do tratamento dispensado aos prisioneiros dos campos de concentração nazistas. Há uma referência implícita aos relatos memorialísticos de sobreviventes de campos de concentração e extermínio como Elie Wiesel e Primo Levi. O uniforme listado, indumentária que marca a iconografia desta experiência histórica, aparece pela primeira vez, assim como o acompanhamento de música erudita que embalava o cotidiano dos aprisionados. Em um diálogo em uma oficina destes uniformes, Karl é introduzido ao sistema de identificação dos detidos: triângulo vermelho para prisioneiros políticos, verde para prisioneiros comuns, roxo para testemunhas de Jeová, rosa para homossexuais, marrom para os ciganos. Os dois triângulos amarelos sobrepostos ao contrário formam a estrela que identifica os judeus. Esta cena tem a função de apresentar ao telespectador as outras vítimas do regime.

Na sequência da prisão de Karl, outro personagem ariano que se recusa ao conformismo diante das perseguições nazistas aos judeus é apresentado ao público. Durante uma missa na qual estão presentes Inga Helms e seus pais, um padre apresenta um sermão no púlpito:

PADRE LICHTENBERG: Rezemos em silêncio pelos filhos de Abraão. Aí fora está em chamas uma sinagoga que, como esta igreja, também é a casa de Deus. Em muitas igrejas foram distribuídos panfletos advertindo-nos que se mostrássemos sentimentos para com os judeus cometeríamos traição. Esta igreja e este padre rezarão pelos judeus. Rezaremos por todas as vítimas, por todos os que enfrentam estas provas terríveis, por todos os inocentes.

Enquanto o padre prossegue com o sermão alguns fiéis visivelmente incomodados se retiram. Erik Dorf, oportunamente presente no templo, apenas observa enquanto Herr Helms condena a atitude do sacerdote e sugere a Inga e sua mãe deixarem a igreja. Reafirmando seu compromisso com a família Weiss e com todos os judeus vítimas da política nazista, Inga se ajoelha para orar, permanecendo.

Erik procura o padre Lichtenberg no final da celebração litúrgica para dizer que ele está mal-informado e que Hitler fez um acordo com o Papa Pio XII. O oficial da SS 
explica que o Vaticano vê a Alemanha nazista como "o último bastião entre a Europa cristã e o bolchevismo".

PADRE LICHTENBERG: Vejo judeus sendo atacados nas ruas e enviados à prisão sem motivo.

ERIK: São inimigos do Reich. Estamos envolvidos em uma guerra, padre.

PADRE LICHTENBERG: Uma guerra contra inimigos armados ou contra judeus indefesos?

ERIK: Padre, eu imploro que seja mais moderado em suas considerações.

PADRE LICHTENBERG: Seguirei minha consciência.

ERIK: Não a deixe desviá-lo do caminho. Deve saber que a maioria dos líderes religiosos apoiam nossas medidas.

PADRE LICHTENBERG: Então você sabe a distinção entre mestres da cristandade e aqueles que distorcem e modificam esses ensinamentos.

O sermão em defesa dos judeus feito pelo Padre Lichtenberg recupera o exemplo de uma pequena parcela do clero que se posicionou de maneira crítica em relação ao caráter persecutório da política nazista, não somente no que diz respeito a este grupo mais também a outros considerados inimigos do Reich ou que não se adequavam ao modelo de sociedade preconizado por Adolf Hitler. Embora esta posição de resistência tenha de fato ocorrido em algumas esferas e membros do partido nacional-socialista representassem uma minoria nas igrejas cristãs, o discurso nacionalista de uma revitalização da pátria nos moldes do conservadorismo nacionalista atraia a simpatia de uma parcela considerável da cristandade alemã, tanto católica quanto protestante ${ }^{79}$. Ao mesmo tempo, a prédica do personagem do Padre Lichtenberg encontra eco na considerável parcela de cristãos norte-americanos entre o público telespectador da minissérie.

Vale recuperar aqui a relação entre o evidente esforço de algumas instituições judaicas envolvidas na promoção da minissérie para o público cristão, documentada em memorandos e no material educativo de divulgação, e a representação no teledrama de

\footnotetext{
${ }^{79}$ FRIEDLÄNDER, op. cit, p. 99.
} 
um sacerdote católico que corajosamente enfrenta o perigo nazista na defesa dos judeus. Padre Lichtenberg refere-se aos judeus como "filhos de Abrãao" e faz referência a uma sinagoga que também é a casa do senhor. Há neste trecho uma clara distinção a respeito da crença judaica que indica claramente uma defesa não restritiva apenas a judeus convertidos ao cristianismo, mas a todos, incluindo a maioria que preservou a sua fé israelita. O historiador Saul Friedländer destaca que as igrejas cristãs da Alemanha nazista, tanto católicas quanto protestantes, "tentavam manter a primazia do batismo sobre a raça e a santidade do Antigo Testamento" 80 , o que caracteriza a atitude do padre como uma exceção que a narrativa fictícia procura destacar. Ao distinguir os "mestres da cristandade" dos que distorcem os ensinamentos cristãos, o sacerdote não ignora a influência do nazismo nos quadros do clero ou de outras igrejas cristãs reformadas, mas enfatiza também que a essência da fé permaneceu intacta naqueles que resistiram por conta de sua compaixão pelos perseguidos.

A clínica de Joseph Weiss e o apartamento da família são confiscados pelos nazistas após a deportação do médico para a Polônia. Não suportando a deterioração de sua situação, os pais de Berta se suicidam. Sem lar, Berta, Rudi e Hannah são acolhidos por Inga. Enquanto isso, Joseph Weiss cruza a fronteira da Polônia e reencontra seu irmão Moses, que o espera para levá-lo à Varsóvia. Franz Lowy, um antigo paciente de origem polonesa que também foi obrigado a emigrar com a esposa, o acompanha. Este momento de ajuda mútua do grupo de judeus deportados é seguido por sua marcha adentrando o território polonês. Simbolicamente tal marcha também simboliza o início da jornada de reencontro deste grupo com sua identidade judaica, reforçada pela segregação imposta pelo regime. Se a marcha para o Leste tem a conotação de um futuro incerto, esta deportação e posterior segregação é também um mecanismo de afirmação de identidade, mesmo que compulsória. Rudi Weiss também inicia neste ponto da narrativa o início do cumprimento de seu destino heroico. Abrigado com Berta e Hannah no apartamento de Inga, o jovem não se adapta à imobilidade diante do embrutecimento do regime em relação aos judeus. Com o apoio da cunhada, decide deixar Berlim, mesmo com destino incerto.

No apartamento de Inga, Hannah e Berta tentam adaptar-se à vida de refugiadas, aguardando notícias de Karl e Joseph. Os pais de Inga não escondem o seu

\footnotetext{
${ }^{80}$ Idem, p. 99.
} 
descontentamento pela decisão da filha de hospedar os familiares de seu marido judeu e constantemente ordenam que ela as expulse de casa. Reafirmando sua retidão de caráter e sua lealdade, Inga ignora tais ordens. O descontentamento velado da família Helms pela união de sua filha com um judeu, algo perceptível na cerimônia de casamento, revelou-se então por inteiro. Tal desarmonia é percebida por Hannah, que mesmo imbuída de certa inocência juvenil, já não se convence de que as coisas possam melhorar no curto prazo. Ciente de que a presença das duas entre a família ariana é um estorvo e culpando a mãe pela crença ilusória de que a perseguição nazista seria passageira, Hannah decide fugir pelas ruas de Berlim e é atacada por um grupo de milicianos nazistas, que a estupram.

O desdobramento do ataque sofrido por Hannah servirá para ilustrar uma das medidas mais conhecidas do regime nazista antes da decisão do extermínio sistemático dos judeus e ciganos durante o curso da guerra. Abalada pelo incidente, a jovem enlouquece, e Inga, na esperança de curá-la por meio de assistência psiquiátrica, a interna em uma clínica. Tal internação dá ensejo para a apresentação do programa de eutanásia e esterilização para deficientes físicos e mentais e pessoas consideradas indesejáveis pelo regime. Levada para a clínica de Hadamar, um dos mais famosos centros deste tipo de ação no governo nazista, Hannah acaba sendo conduzida para uma das câmaras de gás do complexo psiquiátrico onde morre asfixiada junto com outros internos. Berta e Inga recebem o aviso de que a jovem teve uma morte natural. Tais procedimentos reencenam a forma pela qual os alemães recebiam o aviso sobre a morte de seus familiares internados em clínicas psiquiátricas.

Heinz Muller, o arquivilão que no primeiro episódio prenunciava o perigo nazista com a sua presença no casamento de Karl e Inga retorna agora tendo como função possibilitar o encontro a jovem ariana com o marido judeu aprisionado em Buchenwald. Trabalhando como um dos supervisores do campo de concentração, Muller torna possível que Inga e Karl se correspondam, mas impõe uma pesada condição para que isso ocorra. Além de aprofundar o seu perfil negativo e colocar-se finalmente como o obstáculo simbólico do jovem casal, Muller revela a Inga as razões de sua filiação ao partido nazista justificando-se por um passado de desemprego e dificuldades e por sua humilde posição de mecânico, em contraponto a Karl, jovem artista filho de uma rica família judia. Ciente da impossibilidade de conquistar Inga voluntariamente e de sua posição de poder na situação, Muller revela as precárias 
condições do trabalho forçado a que Karl é diariamente submetido e adverte Inga sobre o risco eminente de sua morte. É a partir desta advertência que ele oferece a ela a possibilidade de transferir o jovem artista para um estúdio de arte no mesmo campo de concentração sob a condição de que ela se submeta sexualmente a ele. Dentro da chave melodramática do sacrifício, Inga termina por ceder em nome de um objetivo maior: preservar a vida do marido. Muller, enfatizando sua amoralidade e caráter desprezível, faz com que Karl tenha conhecimento a respeito das condições deste acordo, adicionando mais um ingrediente dramático aos infortúnios do jovem casal.

Conforme já apontado, Dorf é o mentor da racionalidade aplicada na operação nazista contra os judeus. Imagens documentando as ações dos Einsatzgruppen ${ }^{81}$ na Polônia, Ucrânia, Rússia ocupada ou pogroms contra judeus nos países bálticos são apresentadas por Erik Dorf a Heydrich, procurando reforçar a autenticidade e a base histórica dos fatos narrados. Estas imagens históricas do registro do processo de extermínio procuram reforçar a autoridade e a noção de verdade sobre os fatos apresentados pelo teledrama dentro do modelo de estratégias de autenticação já citadas aqui. É importante ressaltar que as diversas fotos de arquivo apresentadas por Erik a Heydrich na verdade foram produzidas em momentos históricos distintos, e sua apresentação em série procurando apresentar uma narrativa visual acaba por deturpar seu verdadeiro sentido enquanto documento ${ }^{82}$. No enredo da minissérie, no entanto, a apresentação de tais imagens por Erik é a deixa para que, em um diálogo com seu superior, o jovem oficial possa apontar a falta de organização e a ausência de planejamento por parte dos executores nazistas em relação ao tratamento dispensado à enorme população de judeus agora sob domínio do Reich.

Erik Dorf reafirma que os objetivos de Hitler em relação aos judeus e aos povos eslavos e a necessidade de reassentamento de uma vasta população alemã para a expansão do Reich resultará invariavelmente na aniquilação dos primeiros. Heydrich reforça que o sentido do ódio aos judeus está em sua função prática: ele é o cimento que

\footnotetext{
${ }^{81}$ Os Einsatzgruppen eram comandos mobilizados pelo comandante da SS, Heinrich Himmler, para o extermínio em massa de judeus do leste da Europa após a invasão da União Soviética, na Operação Barbarossa. Tais unidades deveriam lutar contra a resistência à invasão alemã eliminando os representantes do regime comunista mas se destacaram sobretudo nas matanças em larga escala da população judaica. A logística de tais massacres evoluiu para o objetivo genocida da Solução Final. GOLDHAGEN, op. cit, p. 163.
}

${ }^{82}$ MORETTIN (2011), op. cit., p. 197. 
une a Alemanha nazista e, segundo o oficial da SS, permite a tolerância dos países europeus com a brutalidade do regime:
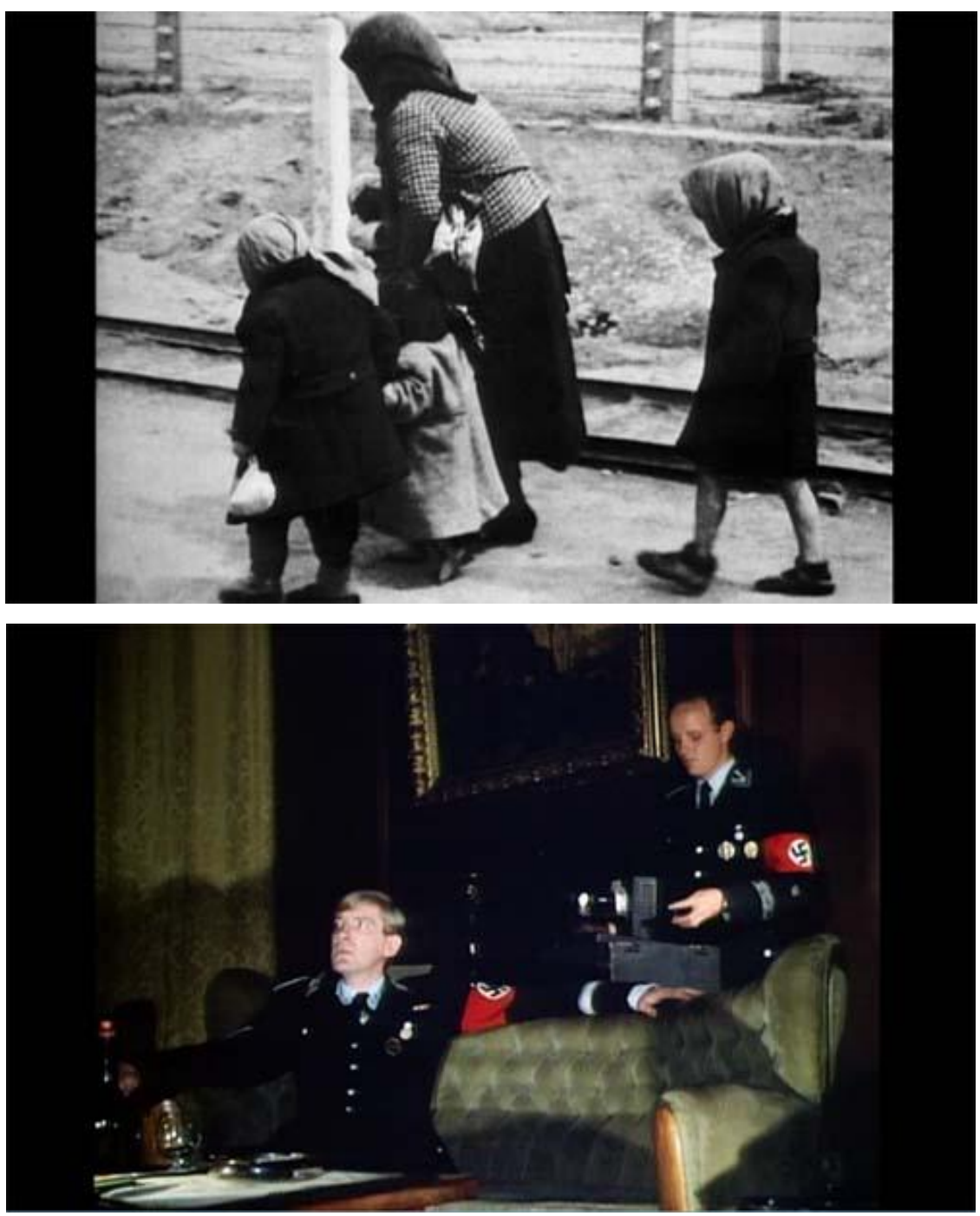

Figura 8 - Utilização de imagens de arquivo documentando o extermínio procurando reforçar a autenticidade da representação histórica na minissérie.

HEYDRICH: Os judeus servem para algum propósito?

DORF: Propósito?

HEYDRICH: Diga-me, Dorf, quanto disso é convicção e quanto é oportunismo?

DORF: Não sou psicólogo, senhor. 
HEYDRICH: Eu acredito que é necessário expulsar os judeus da sociedade? Claro que sim. Mas suponhamos que o racismo seja uma tolice. Os judeus se casam com arianos há séculos.

DORF: Então porque somos tão inexoráveis em eliminar os judeus?

HEYDRICH: O lado prático. O antissemitismo é o cimento que nos mantém unidos. Os cristãos talvez não estejam de acordo com muitas coisas que fazemos, mas como homens de consciência unem-se ao ódio aos judeus.

DORF: Sim, mas temos feito os judeus credores desse ódio?

HEYDRICH: Naturalmente. Assassinos de cristo, envenenadores, agentes de Satã, assassinos de crianças cristãs. Himmler talvez acredite nessa estupidez, mas você e eu sabemos que é superstição medieval. Mentiras, ainda que politicamente úteis. De certo modo servem-nos na medida exata.

DORF: Então a ideologia ou as velhas tradições andam lado a lado com as práticas medidas modernas.

HEYDRICH: Exatamente. Por que acha que não temos oposição? Por que acha que os ingleses e os franceses não protestam? Por que no fundo sentem uma profunda admiração pela forma com que tratamos os judeus.

O diálogo acima repete o tom professoral nas conversas entre Dorf e Heydrich para justificar e sublinhar a recuperação do antissemitismo clássico e religioso pela ideologia nazista no cumprimento de seus objetivos políticos para eliminação da população judaica. Neste exemplo, tal como demonstrado em um diálogo similar do primeiro episódio, Heydrich reforça o caráter moderno do antissemitismo nazista. A eliminação dos judeus é uma medida prática e deve ser tratada dentro da racionalidade moderna. Tal racionalidade não pressupõe que quem a execute compartilhe desse ódio, mesmo que seja necessário acionar o preconceito racial presente no imaginário social. Retomamos aqui a identificação dos burocratas nazistas com a figura de Adolf Eichmann tal qual apresentada por Hannah Arendt. A explicação de Heydrich para Dorf também justifica toda a propaganda nazista contra os judeus e também reforça a responsabilidade de outros países europeus em relação às vítimas do Holocausto. 
Há outro elemento neste diálogo que se relaciona com a formação jurídica de Erik Dorf e sua influência nas decisões de Heydrich (e consequentemente, como já apontado, nas medidas aplicadas aos judeus). Trata-se da linguagem camuflada utilizada pelo Terceiro Reich para se referir a tais medidas, ocultando sob a terminologia burocrática o objetivo final de extermínio. Erik sugere que os judeus passem por uma "quarentena" e sejam confinados em "territórios judeus autônomos", governados internamente pelos próprios judeus sob supervisão do Reich. Heydrich esclarece que essas comunidades funcionarão como etapas para "a regularização do problema judaico". O oficial da SS fica admirado pela rapidez com que passou a utilizar os termos técnicos sugeridos por seu assistente. A nomenclatura nazista que faz referência ao extermínio é apresentada dentro de seu projeto moderno e racionalista através do tom explicativo de Heydrich ${ }^{83}$. Quase todos os diálogos entre estes dois personagens têm a função didática de apresentar ao público o pano de fundo histórico, reafirmando o discurso historiográfico mais geral. Se cabe a Dorf sugerir as medidas a serem adotadas, o papel de Heydrich é explicá-las ao telespectador.

A chegada de judeus deportados na estação próxima ao Gueto de Varsóvia concretiza para o público as medidas anunciadas na cena anterior do diálogo entre Erik e Heydrich. Entre os encarregados de recepcionar o grupo estão Joseph, Moses e Lowy, ligados ao Conselho Judaico que administra o gueto. São eles que orientam os deportados a respeito das condições que os esperam e explicam que as acomodações são para oito ou dez pessoas em cada quarto. Joseph demonstra insatisfação por sua função no Conselho devido às complicações próprias a essa função. É o Conselho Judaico quem decide onde instalar os judeus, qual a cota de comida a ser distribuída e quem está apto para o trabalho, definindo, desta forma, quem deve viver e quem deve morrer. Moses o recorda de que "alguém tem que fazer isso". Berta, último membro da família Weiss a deixar Berlim, reencontra Joseph, que a recepciona na mesma estação de triagem dos deportados. Sua chegada ao gueto permite que as miseráveis condições de vida no local sejam pela primeira vez apresentadas ao público.

\footnotetext{
${ }^{83}$ Conforme aponta Roney Citrynowicz, "toda a correspondência oficial e diálogos cotidianos sobre o extermínio seguia em rigorosa linguagem em código. Assassinato em massa era "tratamento especial", câmaras de gás eram "instalações especiais" ou "casas de banhos" (...). CITRYNOWICZ, Roney. Memória da Barbárie: a história do genocídio dos judeus na Segunda Guerra Mundial. São Paulo: Edusp, 1990. p. 94.
} 
O papel dos Conselhos Judaicos na estrutura burocrática que culminou com o extermínio é uma das questões mais debatidas na história do Holocausto. A presença de Joseph e Moses como parte de sua estrutura administrativa tem como finalidade não só apresentar as diversas responsabilidades e decisões que os membros destes conselhos eram obrigados a tomar como também atenuar, na estrutura narrativa, as indefinições sobre o seu papel. Uma das questões polêmicas levantadas a respeito dos Conselhos Judaicos diz respeito ao seu colaboracionismo com a administração nazista ou da corrupção que permitia a precedência dos menos favorecidos entre os primeiros a serem enviados aos campos de extermínio. Em uma cena em que os membros do Conselho discutem o que fazer após o isolamento do gueto com muros, fica evidente que Joseph e Moses se posicionam entre aqueles que desconfiam dos objetivos nazistas em relação aos judeus. A decisão final tomada pelo presidente do Conselho, Doutor Kohn (que não está claramente identificado como Adam Czerniakow, o personagem real que foi o presidente do Judenrat do Gueto de Varsóvia até 1942), é a de colaboração com os nazistas na crença de que os judeus são úteis a eles em alguma medida.

O núcleo do Conselho Judaico revela um claro conflito entre os judeus do gueto. De um lado os membros do Conselho e sua atitude de colaboração com os nazistas em nome da sobrevivência que usam a justificativa da impossibilidade de enfrentamento direto da poderosa máquina de guerra do Terceiro Reich. Tal colaboração está ligada a um certo conformismo em relação ao antissemitismo histórico reiterada na fala do presidente do Conselho: "Devemos colaborar com eles, a Polônia foi conquistada. Somos o que sempre fomos, vítimas". Longe de um aprofundamento mais sofisticado que procurasse destacar as intrincadas relações entre o Conselho Judaico e sua responsabilidade no extermínio (algo difícil de apresentar no esquema simplificado do melodrama), a narrativa da minissérie procura opor à colaboração compulsória o desejo de resistência dos membros do gueto. A progressão deste conflito, como será possível verificar nos episódios seguintes, marcará o tom político do discurso de memória que a minissérie procurou recuperar.

Este polo narrativo da resistência judaica tem em Rudi Weiss o seu maior exemplo. Foragido de Berlim, o jovem chega à Praga, na República Tcheca sob ocupação nazista, e testemunha as primeiras medidas contra a população judaica local, oficialmente anunciadas por um membro da comunidade. Uma jovem o observa a certa distância na porta de um estabelecimento comercial e a troca de olhares entre os dois 
denuncia um interesse que resultará em uma aproximação amorosa. Interpelado por guardas que solicitam seus documentos, Rudi é salvo pela mesma jovem que declara aos policiais conhecê-lo. A jovem, também judia e que o abriga em sua loja, é Helena Slomova, cujos pais foram deportados para a Polônia. O encontro, além de formar um novo par romântico da trama, revela o encontro de Rudi com o sionismo. O diálogo a seguir explicita o desconhecimento do jovem judeu a respeito dos sionistas e de sua ideologia e até certa descrença em relação a esse ideário:

RUDI: Esta loja é sua?

HELENA: Não, é dos meus pais. Foram mandados para a Polônia. Não sei onde estão e não tenho notícias deles.

RUDI: Por que os levaram?

HELENA: Disseram que meu pai era agente sionista.

RUDI: Sionista? Desses que querem ir para a Palestina?

HELENA: Por que você acha graça?

RUDI: É que havia poucos em Berlim. Velhos barbudos e garotos com sacolas recebendo doações.

A estranheza de Rudi em relação ao sionismo está de acordo com sua postura de judeu-alemão assimilado para quem a noção de um Estado judeu na Palestina é algo pouco conhecido. Sua jornada heroica no teledrama ganha um sentido maior ao encontrar-se com Helena, que se tornará o veículo pelo qual sua identidade judaica será despertada em clara relação à luta sionista. Cientes das medidas restritivas aos judeus que resultarão na inevitável deportação em um curto prazo, o jovem casal decide abandonar Praga e mergulhar na clandestinidade, fugindo em direção à Russia. 


\subsection{Segundo episódio: "The Road to Babi Yar"}

O segundo episódio de Holocausto, além de dar prosseguimento à sequência de infortúnios da família Weiss, apresenta alguns aspectos do esforço nazista contra a população judaica do leste da Europa. Varsóvia, Praga, Kiev e pequenos vilarejos do front oriental são o cenário das ações dos diversos grupos engajados na luta contra o “inimigo judeu”. É importante ressaltar que este é o período anterior à Conferência de Wansee, que estabeleceu os termos do que posteriormente ficaria conhecido "Solução Final do problema judaico" (Endlosung). Mantendo certa proximidade com a cronologia histórica, o destaque deste trecho da narrativa da minissérie está na ausência de racionalidade nazista ao lidar com uma enorme população de judeus absorvidos ao Reich com a expansão alemã nos primeiros anos da guerra.

O desfecho do segundo episódio está centrado no planejamento e execução dos Einsatzgruppen, apresentando pela primeira vez ao telespectador as primeiras etapas do extermínio da população judaica sob jurisdição do Terceiro Reich. A invasão da União Soviética pelo exército alemão em 1941 abriu caminho para as primeiras ações contra esta população nas áreas dominadas pela Alemanha. Heydrich reune Erik e outros personagens nazistas históricos como Otto Ohlendorf, Paul Blobel e Ernst Biberstein para detalhar as medidas a serem tomadas em relação aos judeus e outros inimigos do Reich no front russo. Erik é designado por Heydrich a supervisionar pessoalmente as ações das unidades da SS encarregadas da ação. Mais uma vez os oficiais advertem sobre o uso de termos explícitos como "extermínio" ou do cuidado no registro documental de tais ações. Erik lembra que "nem o próprio Führer escreveu nada a respeito". Devido à escala das execuções, o recrutamento de milícias locais de ucranianos e lituanos é apontado como um braço de apoio da SS em tais ações. A importância desta cena na narrativa está no fato de que pela primeira vez o discurso narrativo destaca claramente os judeus como principais inimigos da Alemanha nazista, como é possível concluir a partir do diálogo abaixo:

OTTO OHLENDORF: Permita-me dizer, capitão. Este novo programa, estes comandos de ação, serão mais abrangentes do que um reassentamento? 
HEYDRICH: Ohlendorf, todos nós sabemos disso. Senhores, o segredo é a mobilidade. Conquistada uma região, procurem os judeus, façam a transferência e ajam de acordo com o combinado. Não se preocupem com o exército, os generais nos temem tanto quanto os judeus. Leia a ordem, Dorf.

ERIK DORF: "Instruções gerais para os líderes políticos segundo a ordem do Führer de 30 de Março de 1941. Há onze categorias de pessoas na União Soviética classificadas de acordo com a nossa jurisdição."

PAUL BLOBEL: Jurisdição, bela palavra. Uma vala e uma metralhadora.

ERIK DORF: Estão incluídos nessa categoria os criminosos, ciganos, funcionários do estado soviético e do partido, agitadores, comunistas e todos os judeus.

OTTO OHLENDORF: Esta lista não é do exército?

HEYDRICH: Isso mesmo. Quando o Führer deu essas ordens deixou muito claro o objetivo. $\mathrm{O}$ exército será o nosso humilde servidor.

ERIK DORF: O Führer salientou que a campanha da Rússia será completamente diferente das demais. Estas foram suas palavras. A campanha será executada com uma dureza e uma ferocidade sem precedentes. Abre aspas: "Os russos devem ser tratados como seres inferiores, nascidos para a escravidão, semelhantes aos judeus."

ERNST BIBERSTEIN: Haverá alguma exceção? Casos especiais?

ERIK DORF: Sim, poderão ser excluídos alguns elementos russos fiéis e ucranianos que desejam trabalhar conosco.

ERNST BIBERSTEIN: E em relação aos judeus? Alguma exceção?

HEYDRICH: Nenhuma.

PAUL BLOBEL: Está bastante claro. Achei que este era o tema da reunião.

ERIK DORF: Há dois anos atrás o embaixador italiano fez objeções a política judia do Führer. Mussolini se ofendeu com isso. O Führer respondeu que durante quinhentos anos o nome Adolf Hitler seria venerado por uma coisa: ter varrido os judeus da face da terra. 
As palavras de Erik reforçam o fato de que, na narrativa dramática, a decisão de exterminar os judeus é anterior à Conferência de Wansee. Os primeiros passos nessa direção foram dados, conforme apontado acima, por meio dos Einsatzgruppen, mas a plataforma política nazista já previa tal destino em relação aos judeus. Há também aqui a referência ao papel do exército alemão como um mecanismo de apoio da violência nazista no front russo. Esta "guerra contra os judeus" tem primazia em relação à campanha militar, tal como sugere a cena.

Executando as medidas discutidas na cena anterior, Erik Dorf, Paul Blobel e outros oficiais de alta patente da SS se aproximam de um dos vários locais de massacre onde homens completamente nus aguardam o fuzilamento, próximos a uma vala aberta. Blobel ignora a presença de Erik e ordena o fuzilamento do grupo de judeus. Algumas vítimas ainda apresentam sinais de vida e Blobel tem a ideia de retirar a arma do coldre de Erik obrigando-o a descer à vala dos fuzilados e terminar o serviço iniciado:

PAUL BLOBEL: Soldado de gabinete, capitão de papel. Desça lá e acabe com os agonizantes.

ERIK DORF: Parece que estão todos mortos.

PAUL BLOBEL: Temos que ter certeza. Vá em frente!

ERIK DORF: Isso é ridículo.

PAUL BLOBEL: Seu sangue esfriou, Dorf? Ou você molhou as calças? Dê parte contra o bêbado do Blobel que não faz uma operação limpa. Maldito seja! Desça lá e acabe com isso.

Dorf hesita por alguns segundos, mas se dirige à vala comum carregando sua valise em uma mão e a arma na outra:

PAUL BLOBEL: É como comer fígados, Dorf. Quando você começa, não pode parar. Pergunte como é aos rapazes, capitão. Mate dez judeus e os próximos cem serão mais fáceis. Mate cem e aprenderá a matar mil.

Erik ergue a arma em direção a uma das vítimas, mas fica indeciso por alguns instantes até finalmente desferir dois tiros e silenciá-la. Este momento em que o burocrata nazista encontra-se frente a frente com a realidade dos crimes estabelece uma 
conexão direta entre a ordem expressa nas etapas burocráticas dos responsáveis pelo extermínio e seus executores diretos. O gatilho de Erik Dorf não é apenas o da arma em punho (de fato é a única vez em que ele comete diretamente um assassinato), mas o da caneta que despacha a ordem para os massacres. Recupera-se aqui a descrição dada por Hannah Arendt para Adolf Eichmann ${ }^{84}$, que alegava em seu julgamento em Israel que nunca havia cometido diretamente qualquer crime de assassinato.
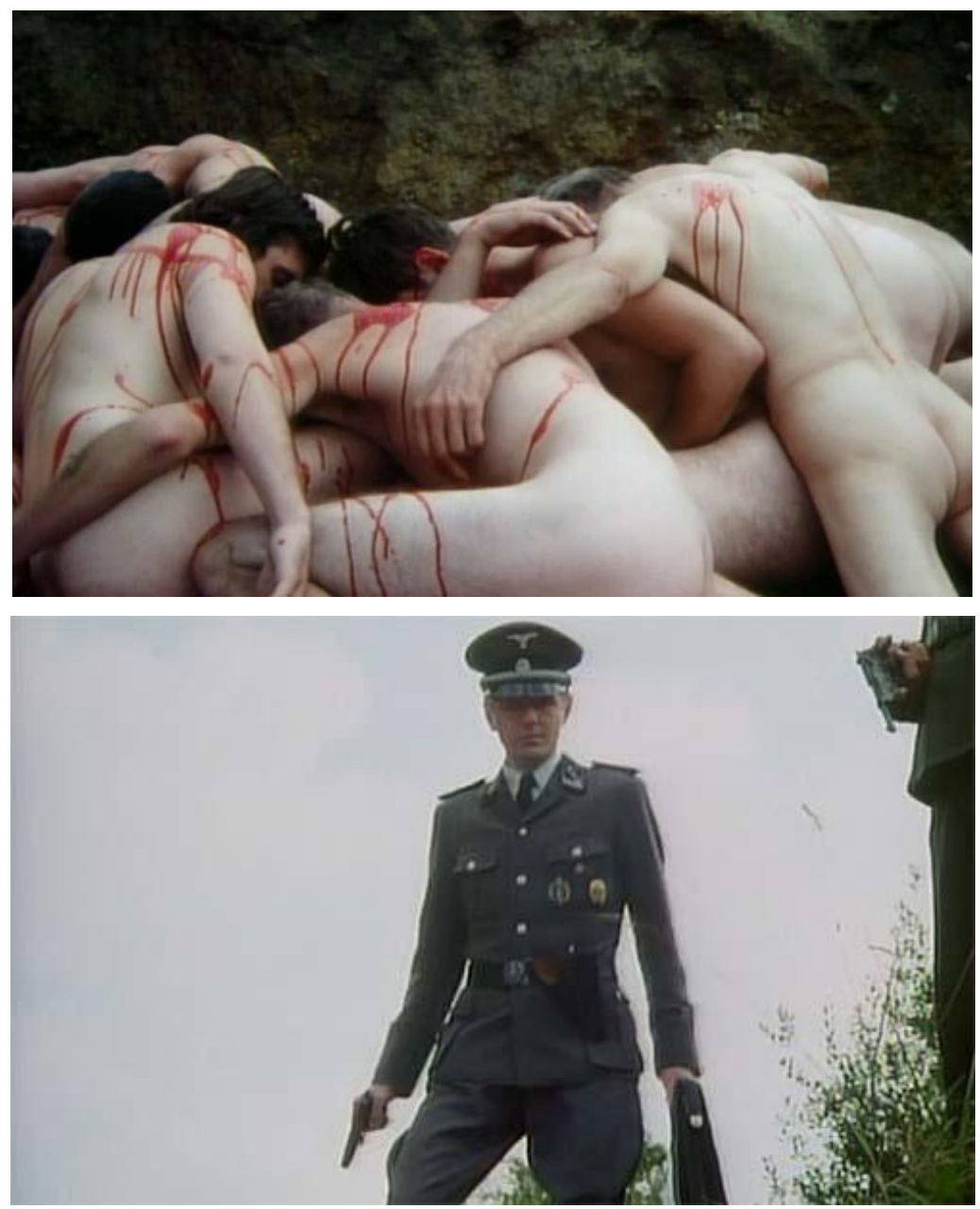

Figura 9 - Nesta cena, a arma na mão direita de Erik Dorf e a pasta de documentos na mão esquerda reforçam o sentido de responsabilidade criminal dos burocratas nazistas que, por não estarem diretamente envolvidos com o aparato de extermínio, alegavam apenas o cumprimento de ordens superiores em seu julgamento.

\footnotetext{
${ }^{84}$ De acordo com Hannah Arendt, a acusação em seu julgamento em Israel "perdeu muito tempo em um malsucedido esforço para provar que Eichmann, pelo menos uma vez, matara com as próprias mãos (um menino judeu na Hungria)". ARENDT, op. cit., p. 34.
} 
Há no final deste episódio um embate entre Erik e Blobel que representa o conflito entre a brutalidade desenfreada das primeiras ações de massacre contra os judeus (principalmente através das ações dos Einsatzgruppen) e a racionalidade do processo de extermínio que terminou por se estabelecer no decorrer da guerra. Nos episódios seguintes cabe a Erik trabalhar diretamente no esforço para racionalizar este processo, principalmente após a Conferência de Wansee.

Enquanto, de acordo com a narrativa histórica, a cúpula nazista caminha rapidamente para uma decisão definitiva em relação ao destino dos judeus da Europa, a narrativa ficcional centra seu foco no Gueto de Varsóvia e Theresienstadt. De algum modo todos os membros da família Weiss acabam envolvidos em alguma instância nas variadas formas de resistência à perseguição e genocídio praticado pelo governo nazista. Assim, o despertar de uma identidade judaica até então adormecida para Joseph e Berta Weiss ocorre no cotidiano do Gueto de Varsóvia e em seu direto envolvimento com os combatentes que planejam o futuro levante. Rudi Weiss e Helena se aliam a um grupo de guerrilheiros judeus que os acolhe e passam a sabotar o avanço das tropas alemãs em direção à Rússia. Até mesmo Karl, que na minissérie é o símbolo da vítima passiva e conformada, termina por se envolver com um trabalho artístico de resistência junto aos artistas do Gueto de Theresienstadt.

Dentro desta perspectiva cada vez mais política no discurso narrativo que aponta para estratégias de resistência diante do aprofundamento das perseguições por parte do aparelho estatal nazista, surgem alguns personagens que ajudam a compor o quadro desta nova realidade. Joseph e Berta aprofundam seus laços com outros habitantes do gueto, ele como médico e membro do conselho judaico e ela como professora. Um dos novos personagens que surgem na trama é o garoto Aaron Feldman, parte do enorme grupo de crianças contrabandistas do gueto que se arriscavam escapando pelos muros na parte ariana de Varsóvia em busca de comida e outros suprimentos negados aos judeus. Aaron representa não só as vítimas infantis do Holocausto, mas também a natureza impetuosa e a coragem inocente dos que não hesitam em resistir. Retornando de uma de suas fugas em busca de alimento, o menino é advertido por Berta e Joseph Weiss a respeito do perigo que está correndo caso seja capturado por algum dos guardas judeus ou por algum dos oficiais da SS. 
$\mathrm{Na}$ sequência da cena de advertência ao jovem contrabandista revela-se o direcionamento do discurso narrativo do teledrama (e consequentemente o discurso de memória atrelado a este) no sentido de uma jornada de resistência por parte dos personagens da família Weiss presentes no Gueto. Em uma reunião do Conselho Judaico, o líder Doutor Kohn afirma que deve-se dar prioridade aos judeus produtivos e saudáveis. Joseph responde afirmando que todos devem ser alimentados. A questão dos contrabandistas vem à tona, pois aparentemente a repressão por parte dos alemães e da polícia judaica aumentou consideravelmente:

DR. KOHN: Estão ameaçando fuzilar vinte judeus por cada contrabandista que for preso.

JOSEPH: Os garotos que passam pelos esgotos podem ser nossa salvação.

DR. KOHN: Bobagem. Eles matarão a todos nós.

Uma voz interrompe a discussão. Trata-se do personagem histórico Mordechai Anielewicz, um dos principais líderes do Levante do Gueto de Varsóvia:

ANIELEWICZ: De qualquer modo eles nos matarão...

DR. KOHN: Como assim?

ANIELEWICZ: Eles nos matarão de qualquer jeito.

DR. KOHN: Como você sabe?

ANIELEWICZ: Já começou. Os nazistas começaram pela Rússia. Não há mais guetos. Pretendem matar todos os judeus da Europa.

DR. KOHN: Isso é ridículo.

Anielewicz se apresenta aos membros do conselho e afirma que os contrabandistas devem continuar sua atividade e contrabandear não só comida mas também armas e granadas. Sua fala é categórica: "Se o Conselho é covarde demais para agir, os sionistas agirão! Não pretendemos morrer sem lutar”. O jovem sionista é violentamente expulso da reunião, mas antes conclui seu discurso: "Vocês todos morrerão sendo polidos e abaixando a cabeça. Vocês não têm autoridade, não representam ninguém!"”. 
Mordechai Anielewicz sintetiza o discurso da resistência e da postura de nãocolaboração com a ocupação nazista. Jovem e impetuoso, em oposição a um conselho formado em sua maioria por anciões judeus, ele simboliza a ligação entre os judeus do gueto e o sionismo. As discordâncias de Joseph e Moses em relação às decisões do Conselho acabam por posicioná-los na mesma esfera de Anielewicz, e tal interação naturalmente segue um curso em direção a um maior alinhamento com essa postura no decorrer da narrativa. A questão dos contrabandistas torna-se o estopim que convence Moses a juntar-se aos sionistas. Ele revolta-se com o fuzilamento de mulheres que haviam desobedecido ao regulamento nazista ao saírem do gueto em busca de comida. Neste momento Anielewicz e seu grupo o convidam para juntar-se à causa. Um personagem já previamente apresentado ao telespectador também faz parte do grupo de rebelados: o tipógrafo Franz Lowy. Temendo ser executado ao aliar-se à resistência, Moses recebe dos próprios rebeldes o lembrete de que sua morte ocorrerá de qualquer maneira, cedo ou tarde. A crença em alguma lógica da política de Hitler e na utilidade dos judeus para o Terceiro Reich o faz duvidar do objetivo final de aniquilação dos judeus pela máquina nazista. Franz Lowy o lembra que, nas atuais circunstâncias "a lógica não prova mais nada”. Neste momento ele lê o manifesto impresso produzido pelos rebeldes: “A todos os judeus de Varsóvia: coloquemos fim à apatia! Acabou a submissão ao inimigo. A apatia pode causar nosso colapso moral e pode tirar de nossos corações o ódio pelo invasor. Pode acabar como nosso desejo de lutar...”. Após ler este trecho do manifesto, Moses confirma sua adesão. O manifesto da resistência judaica no gueto é claro em relação a um dever moral de rechaço a qualquer passividade ou colaboração com a estrutura nazista cujo objetivo maior é o extermínio dos judeus da Europa.

O tema da passividade das vítimas é recorrente não só na oposição clara a esta postura evidenciada nos membros da resistência como também na fala dos nazistas que gerenciam os massacres contra a população judaica. Em uma cena em que filmes de arquivo documentando a ação dos Einsatzgrupen são exibidos por Erik Dorf para Reinhard Heydrich, o oficial da SS observa um grupo de judeus sendo executados com tiro na nuca em valas abertas na Letônia: "veja como seguem tranquilos, nem sequer choram". Dorf acrescenta: "estão quase quietos, quase como um rito religioso". A cena é finalizada com alguns segundos do filme de arquivo mostrando os oficiais da SS jogando terra sobre os corpos. A referência de Dorf para a semelhança do 
comportamento passivo das vítimas judias como uma espécie de "ritual religioso" parece apontar para uma conexão entre essas vítimas e sua identidade atávica ligada a um comportamento de submissão e conformismo em relação às perseguições sofridas ao longo da História.

Rudi, que personifica a resistência a essa atitude conformista no núcleo familiar dos Weiss, chega a Kiev com Helena Slomova e, dentro do jogo de coincidências da trama melodramática, reencontra Hans Helms. O casal se esconde dos nazistas em um edifício abandonado e quando alguns homens da SS estacionam nas proximidades ele imediatamente reconhece o irmão de Inga entre os soldados. A cena do reencontro ocorre durante um ataque da guerrilha russa a Kiev que atinge o edifício onde Rudi e Helena se refugiam. Atingido pelos escombros da explosão, Hans é socorrido pelo casal. A presença de Hans nesta cena permite que Rudi seja informado a respeito do destino de seus familiares, além de reforçar a polaridade negativa em que se encontra o jovem soldado alemão. Hans promete dar proteção ao casal, mas, reforçando seu caráter dissimulado, termina por denunciá-los como judeus a seus superiores e os dois são presos. O castigo ao jovem oficial alemão ocorre na mesma cena, quando ele é vítima fatal de outra explosão causada pela guerrilha russa.

A chegada de Rudi e Helena em Kiev os posiciona como testemunha de outro grande evento da narrativa histórica do Holocausto: o massacre dos judeus de Kiev na ravina de Babi Yar entre 29 e 30 de Setembro de 1941. Os judeus da cidade foram convocados pelo comando nazista a se reunirem, com bagagem e comida, em um ponto específico da cidade. Acreditando na eminente deportação para um campo de trabalho, eles foram deslocados para Babi Yar, nas proximidades, onde cerca de 33.700 indivíduos foram fuzilados durante três dias. Segundo o relato dos poucos sobreviventes e algumas testemunhas, as vítimas (homens, mulheres e crianças) eram obrigadas a ficar nuas e empilhar seus pertences nas proximidades. O pelotão de fuzilamento era composto por tropas da SS e por colaboradores ucranianos.

Na narrativa fictícia, Rudi e Helena estão entre os judeus encaminhados ao local do massacre. Enquanto a longa fila dos judeus de Kiev caminha a passos lentos para seu local de execução, tropas da SS se aproximam na estrada. Em um dos carros está Erik Dorf e Paul Blobel, que também testemunharão as ações. Aproveitando-se da desatenção de um oficial responsável pela vigilância dos judeus, Rudi e Helena se 
esgueiram pela vegetação e deixam o grupo, concretizando a sua missão de testemunha do evento. A representação do massacre novamente recupera a questão da passividade das vítimas judias, exemplificada no diálogo entre Blobel e Dorf, que observam a ação do alto da ravina. Blobel menciona a Erik que o cemitério judeu de Kiev está situado nas proximidades, o que torna o local, segundo ele, bastante apropriado:

ERIK DORF: Está claro que isso continua sendo uma operação de reassentamento.

PAUL BLOBEL: É exatamente o que dissemos a eles e é exatamente o que eles acreditam.

ERIK DORF: É inacreditável como colaboram.

PAUL BLOBEL: Isso é a prova de que não merecem viver.

O grupo de judeus se aproxima do local das execuções enquanto a música vai acompanhando seus passos.

PAUL BLOBEL: Estimávamos uns seis mil, mas os oficiais disseram-me que há mais de trinta mil judeus lá embaixo.

ERIK DORF: Simplesmente assombroso.

Escondidos entre os arbustos, Rudi e Helena também se aproximam do local e assistem aos judeus despindo-se e entregando seus bens aos soldados da SS e seus colaboradores. Completamente nus e enfileirados, homens, mulheres, velhos e crianças são fuzilados em sequência. O testemunho de Rudi e Helena aponta para a brutalidade e escala monstruosa do massacre:

HELENA: Mulheres e suas crianças. Oh, Rudi, é horrível.

RUDI: Não acreditarão em nós. Dirão que mentimos. Porque ninguém pode fazer isso a outras pessoas.

A fala de Rudi claramente refere-se a seu testemunho conjunto com Helena, mas também pode ser considerada em relação ao espectro mais amplo dos judeus sobreviventes que testemunharam o grau de atrocidade das ações nazistas. Ao dizer que tais testemunhos poderão ser alvo de incredulidade ou mesmo de mentira ou invenção, 
Rudi Weiss cria uma conexão com o discurso do negacionismo e do revisionismo do Holocausto. Tais alegações ganharam destaque, sobretudo a partir da década de 70 e despertavam amplas discussões públicas durante o período em que a minissérie "Holocausto" foi produzida e exibida. Um exemplo deste tipo de alegação pode ser exemplificado em um anúncio pago pela Revisionist Press, uma entidade de estudos revisionistas que procurava minimizar a escala dos crimes cometidos contra os judeus no Holocausto, no jornal The New York Times. A publicação do anúncio foi feita em 20 de Abril de 1978, um dia depois da exibição do último capítulo da minissérie. O anúncio intitulado "Holocausto ou Fraude?" polemizava a natureza fictícia do teledrama que procurava mostrar ao grande público a "verdade" sobre o evento histórico. ${ }^{85}$
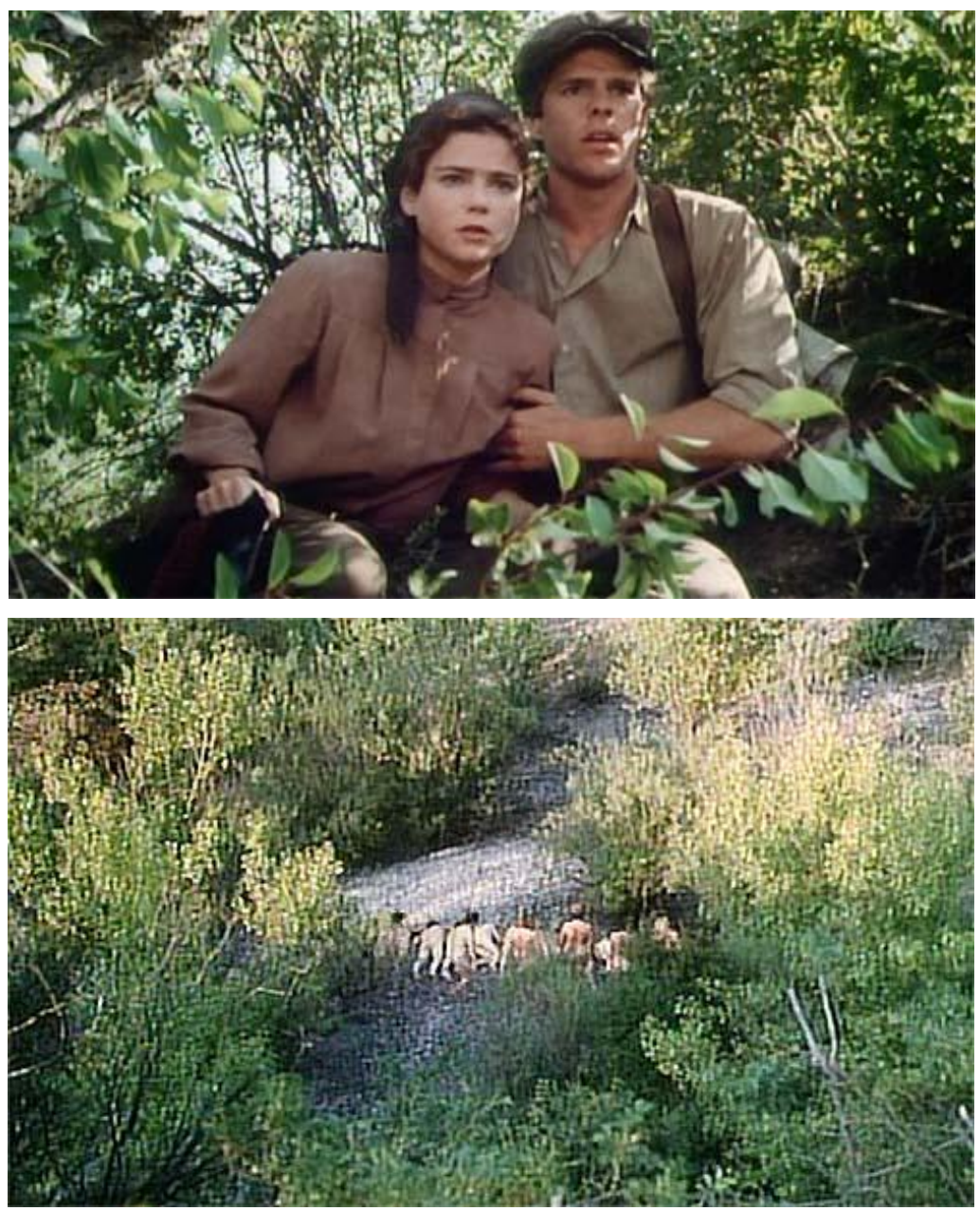

Figura 10 - Rudi e Helena testemunham o massacre de Babi Yar, na Ucrânia ocupada. A cena reforça a importância do testemunho dos sobreviventes no combate aos discursos de negação do Holocausto que proliferaram na época da produção do teledrama.

${ }^{85}$ THE NEW YORK TIMES. New York, 20 de Abril de 1978. 
O enredo vai deixando claro para os membros da família Weiss que o objetivo final dos nazistas é a aniquilação total dos judeus. O testemunho de Rudi reforça esse aspecto, e no Gueto de Varsóvia chegam notícias de outros massacres de civis. Um mensageiro do Gueto de Vilna, na Lituânia, revela aos membros do Conselho Judaico e do grupo de rebeldes formado por Mordechai Anielewicz que as informações nazistas sobre o funcionamento dos guetos e campos de trabalho são mentiras. Segundo o mensageiro, as mortes de judeus não são represálias, mas fazem parte de um plano maior de extermínio em andamento. Prosseguindo em seu relato, ele afirma que dos 80 mil judeus do gueto de Vilna, apenas 20 mil ainda permaneciam vivos. Os homens do conselho, entre os quais está Joseph, demonstram descrença no fuzilamento de cerca de 60 mil judeus. O mensageiro acrescenta que os judeus foram mortos com rajadas de metralhadoras, sem lágrimas e sem resistir e que todos os guetos sob administração nazista deverão ser liquidados em breve.

Mordechai Anielewicz ouve o relato do mensageiro de Vilna e sua expressão revela a confirmação de sua tese sobre o objetivo final dos nazistas. Também é perceptível em sua expressão alguma ansiedade em relação à decisão a ser tomada uma vez que os eventos revelados corroboram esta tese. Assim como a mensagem distribuída pela resistência judaica em Varsóvia, os judeus de Vilna também distribuíram seus panfletos, e um deles, trazido pelo mensageiro, é lido por Joseph Weiss: “A todos os judeus do gueto: não iremos para a morte como cordeiros ao matadouro. Jovens, apelo a vocês para que não creiam naqueles que lhes querem mal. Hitler planeja aniquilar os judeus, e somos os primeiros. É verdade que estamos fracos e sozinhos, mas a única resposta válida ao inimigo é a resistência. Vale mais morrer lutando do que viver pela clemência do carrasco. Vamos nos defender até o último suspiro. Gueto de Vilna”.

Tem início um novo debate entre os membros do Conselho Judaico sobre a melhor decisão a ser tomada. Doutor Koh persiste em seus argumentos afirmando "que se a morte é inevitável, de que adianta resistir?”. Os olhos acesos de Anielewicz diante da perspectiva de uma reação armada ao poderio nazista deixam claro sua predisposição de lutar, evidenciando uma mensagem clara de sintonia entre a causa sionista e a resistência ao inimigo. Neste momento Berta Weiss, que ouvia o debate na reunião do Conselho em outra sala, surge com o dinheiro que restou da família Weiss e que 
permanecia escondido em seu casaco. Berta se dirige a Anielewicz, disponibilizando a ele a quantia: "vocês devem comprar armas". Esta ação de Berta marca sua decisão voluntária, assim como a de Joseph, de alinhamento aos resistentes. O enredo do teledrama adiciona mais uma vez, como nas sugestões dadas por Erik Dorf a Reinhard Heydrich, um elemento ficcional à narrativa histórica sobre o tema. O dinheiro doado pela família Weiss contribui diretamente para parte do financiamento das armas utilizadas pelos combatentes do Levante do Gueto.

É neste momento da narrativa que a decisão nazista a respeito da "Solução Final do problema judaico" é oficializada pela cúpula nazista. Erik Dorf é o único personagem fictício presente em uma conferência em Berlim que reencena a Conferência de Wansee, evento histórico em que as diretrizes relacionadas ao extermínio foram anunciadas. Em nenhum momento fica explícito que se trata exatamente da encenação desta conferência, mas a fala dos líderes nazistas reunidos parece apontar para a reprodução dramática do evento. Reunindo representantes civis e militares da cúpula do partido, a reunião dos líderes nazistas é construída não só para apresentar um suposto debate sobre as medidas anunciadas como também para revelar as conflituosas relações entre os líderes do partido dos diferentes departamentos governamentais do Terceiro Reich.

Heydrich anuncia a decisão de Hitler de eliminar fisicamente os judeus e as etapas administrativas para o extermínio são enumeradas: o envio para campos de trabalho deve resultar na morte de uma parcela dessa população por meio da fome, da desnutrição ou de doenças. Uma outra parcela deverá receber o tratamento adequado com outros métodos. O uso de gás, previamente utilizado nos assassinatos de doentes mentais e deficientes surge pela primeira vez na narrativa como uma opção a ser usada com os judeus. Um representante civil presente na conferência relembra a Heydrich a oposição do Vaticano e de outros líderes religiosos a estas medidas já previamente adotadas e acrescenta a possível reação da comunidade judaica internacional que supostamente controlaria a imprensa, os bancos e até mesmo o governo norte-americano de Franklin Roosevelt. Heydrich responde que "ninguém levantará um dedo para proteger os judeus".

A menção da suposta influência judaica no governo de Roosevelt e a resposta dada por Heydrich que veio a confirmar-se historicamente na execução dos judeus por 
gás nos vários campos de extermínio da Polônia aponta para uma mensagem clara na narrativa de que tal influência, se existiu, foi ineficaz em obter qualquer resultado. Nas raras vezes em que a menção aos massacres contra judeus chegava às páginas dos principais jornais norte-americanos, a identidade judaica das vítimas era ocultada sob a classificação geral de crimes nazistas contra a população civil mais ampla. David S. Wyman, em um estudo sobre a postura dos Estados Unidos em relação ao destino dos judeus durante a guerra, nos dá um exemplo ao relatar a reação da imprensa às manifestações públicas de grupos da comunidade judaica solicitando uma reação política para os massacres. Wyman aponta que, ao relatar um protesto conta os massacres nazistas do Madison Square Garden, o New York Times deixou de mencionar as centenas de milhares de vítimas judias aniquiladas pela máquina nazista. As manifestações públicas foram classificadas pelo jornal apenas como "uma demonstração em massa contra as atrocidades de Hitler" ${ }^{\text {86 }}$.

O percurso heroico de Rudi Weiss, que até este momento na narrativa esteve restrito apenas a sua estratégia de fuga e sobrevivência na clandestinidade, finalmente desabrocha quando ele e Helena, refugiados na Ucrania, defrontam-se com um grupo de guerrilheiros. Ao abrigar-se do frio no celeiro e já sem nenhuma provisão de comida, o casal parece ter chegado ao limite de suas possibilidades. Helena pensa em desistir:

HELENA: Rudi, não podemos viver assim. Não podemos continuar fugindo.

RUDI: Acha que devíamos ter ficado em Praga?

HELENA: Não sei, mas lá pelo menos tínhamos minha casa, comida, meus amigos.

RUDI: Seus amigos estão em campos de concentração.

HELENA (chorando): Sou um estorvo para você, choro demais.

RUDI: Helena, eu também quero chorar, mas aprendi uma coisa quando criança em Berlim. Quando lutamos nunca devemos chorar, mesmo que doa. Sempre tem alguém que quer nos ver chorar. E quando isso acontece, nos matam.

\footnotetext{
${ }^{86}$ WYTMAN, David S. The Abandonment of the Jews: America and the Holocaust: 1941-1945. New York: Phanthon Books, 1984, p. 26.
} 
As palavras de Rudi reforçando a Helena a necessidade de não demonstrar sua fragilidade, mesmo na desesperadora situação de infortúnio, reafirmam não só o seu caráter combatente, mas revelam uma escolha clara pela resistência que está deslocada da reinvindicação da vítima. A vítima (personificação que pode ser aplicada aos judeus europeus) é fraca e passiva e torna-se presa fácil do inimigo nestas condições. O combatente, mesmo que em clara situação de desvantagem, nunca deve demonstrar fraqueza.

HELENA: Rudi, o que vamos fazer?

RUDI: Você me fala tanto dessa nação judia que seus amigos sionistas querem no deserto, cercados por árabes. O homem com a barbicha, qual era o nome dele?

HELENA: Herlz ${ }^{87}$. Não tente me fazer rir outra vez.

RUDI: O que quero é que veja as coisas como são, nada mais. Acredita mesmo que vão conseguir este país sem lutar? Sem matar ou morrer?

A luta pela criação do Estado de Israel, objetivo fundamental do esforço sionista que Rudi conheceu ao unir-se à Helena, está, de acordo com o discurso de Rudi, atrelada à necessidade primeira do combate e da resistência. É neste momento que o grupo de guerrilheiros se aproxima do celeiro onde o casal se refugiou e ordena que os dois saiam com as mãos erguidas. O casal se rende, e Helena afirma que eles são tchecos foragidos de Kiev, ocultando sua identidade judia.

\subsection{Terceiro episódio: "Final Solution"}

Ao perceber que uma das guerrilheiras presentes usa um colar com a estrela de Davi, Helena se dá conta da identidade desses guerrilheiros e confessa que ela e Rudi também são judeus. O clima de tensão é imediatamente quebrado pelo alívio do reconhecimento do semelhante e o grupo se confraterniza entre abraços com a saudação "shalom". O líder do grupo se apresenta como "tio" Sacha, comandante da brigada guerrilheira de Zitomir. Rudi imediatamente se voluntaria e pergunta se o grupo tem

\footnotetext{
${ }^{87}$ Theodor Herlz, jornalista judeu-húngaro, considerado o fundador do moderno sionismo político.
} 
uma arma disponível para ele. Sacha informa a Rudi e Helena que eles tiveram sorte de serem encontrados por um grupo de guerrilheiros judeus. A resistência ucraniana, caso os tivesse encontrado, dispensaria a eles um tratamento brutal semelhante ao reservado ao inimigo alemão. O comentário de Sacha aponta para o conhecido antissemitismo dos grupos guerrilheiros que enfrentaram a ocupação nazista do leste da Europa. A resistência formada unicamente por membros judeus tornava-se assim a melhor garantia para a sobrevivência.

Sacha lidera não apenas os guerrilheiros, mas um grupo maior de judeus sobreviventes dos ataques dos Einsatzgrupen nazistas aos vilarejos judeus da Ucrânia. Vivendo em acampamentos, eles se deslocam fugindo tanto das tropas nazistas quanto dos ucranianos. Ao integrar-se ao grupo, Rudi vivencia com maior proximidade a vida comunitária judaica até então quase desconhecida em sua experiência de judeu-alemão assimilado. O acampamento dos judeus sob a liderança de Sasha funciona como um microcosmo desse laço comunitário em um grupo guiado por guerrilheiros que resistem e combatem os inimigos nazistas em nome da sobrevivência. A presença de mulheres, velhos, crianças e até mesmo de um rabino nesta comunidade funciona como um elemento de convencimento dessa unidade comunitária que a narrativa do teledrama procura ressaltar. É possível também fazer uma aproximação entre o espírito

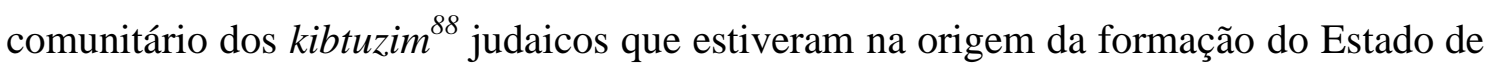
Israel, embora a vida comunitária representada na minissérie esteja aqui basicamente focada no nomadismo em nome da sobrevivência.

A presença de um rabino no grupo, que segue observando os preceitos da fé mesmo em condições adversas da vida itinerante, possibilita a encenação de um ritual religioso que servirá como uma espécie de "batismo" de Rudi no retorno ao seu judaísmo negligenciado. O jovem afirma que o "rabino guerrilheiro" o agrada por tratarse do tipo de religioso capaz de convencê-lo a voltar a frequentar a sinagoga. Na manhã seguinte à sua primeira noite entre os guerrilheiros, ele aproveita a presença do sacerdote para oficializar sua união matrimonial com Helena, com uma celebração seguindo os preceitos da religião judaica.

\footnotetext{
${ }^{88}$ Kibutzim, forma plural de Kibutz, são tipos de estabelecimentos agrícolas coletivos formados por judeus que emigraram para a Palestina combinando ideais sionistas com formas socialistas de organização. In: ENCICLOPEDIA JUDAICA, op. cit., p. 374
} 
O casamento de Rudi e Helena, em evidente contraste com a celebração matrimonial da união de Karl e Inga do início da trama, apresenta ao telespectador os detalhes da celebração religiosa improvisada pelos guerrilheiros judeus. Com um arco de flores na cabeça e o rosto coberto por um véu, Helena é conduzida ao encontro do noivo acompanhada por música klezmer ${ }^{89}$ tocada pelos próprios guerrilheiros. Rudi, tendo os ombros protegidos por um talit $^{90}$ e usando um solidéu, a espera sobre a chupa $^{91}$. O comportamento de Rudi durante a cerimônia revela algum desconforto em relação a um ritual étnico até então desconhecido. A presença do rabino Samuel sobre a chupá recupera a mitologia bíblica, cujo nome remete ao último dos juízes de Israel e o primeiro de seus profetas. O rabino inicia a cerimônia, e a mensagem aos noivos e presentes à celebração reverbera também ao espectador judeu norte-americano. Uma oração em hebraico dá sequência às palavras do rabino. Uma das crianças presentes traz um cálice de vinho que é oferecido pelo religioso a Rudi e que a oferece à Helena. O rabino prossegue com mais algumas palavras em hebraico enquanto o noivo introduz o anel de compromisso na mão esquerda da noiva.

RABINO SAMUEL: Que os vossos anos sejam santificados com alegria e crianças. E que haja amor eterno entre vocês. Na fé de Abraão, Isaac e Jacó eu os declaro marido e mulher.

Há na sequência o ritual da quebra do copo, simbologia da destruição do Templo de Jerusalém e, indiretamente, das catástrofes que atingiram a comunidade judaica ao longo da história. A cena da quebra do copo tem um sentido especial em uma cerimônia realizada na clandestinidade das florestas ucranianas, em um território sob ocupação nazista, o mais terrível inimigo do povo judeu na história moderna. Ao pisar no copo e quebrar o vidro, Rudi ouve as congratulações dos convidados presentes: Mazel Tov! ${ }^{92}$.

\footnotetext{
${ }^{89}$ Klezmer é uma palavra iídiche que significa "instrumento popular judeu". Klezmerin eram os músicos populares judeus askhenazim. Tais instrumentistas apareceram pela primeira vez na Europa Central e Oriental, no final da Idade Média e demonstravam preferência pelos instrumentos de corda e de sopro. Idem, p. 388.

${ }^{90}$ Talit, que em hebraico significa "xale de orações", é um xale geralmente feito de linho, lã ou seda, com franjas do mesmo material. É utilizado na sinagoga ou em orações e ocasiões especiais, como o matrimônio apresentado na minissérie. Assim como o solidéu, é uma indumentária marcante de afirmação da identidade judaica. Idem. p. 759.

${ }^{91}$ A chupá é uma espécie de pálio semelhante a um dossel sustentado em cada um de seus quatro lados por um poste ornamental. Sua cobertura é frequentemente de seda, cetim ou veludo, com bordados de palavras aos noivos. Idem. p. 138.

${ }_{92}$ Mazal tov (em hebraico: טוב מזל) significa literalmente "boa sorte" em hebraico. A forma iídiche "mazel tov" e usada atualmente na congratulação de eventos importantes da vida judaica, como por exemplo um um Bar mitzvah ou um casamento. Disponível em http://pt.wikipedia.org/wiki/Mazal_tov
} 
Após beijar a noiva e ouvir as recomendações paternais de Sasha a respeito de suas novas responsabilidades como marido e futuro pai de família, Rudi se junta a Helena e a outros convidados.
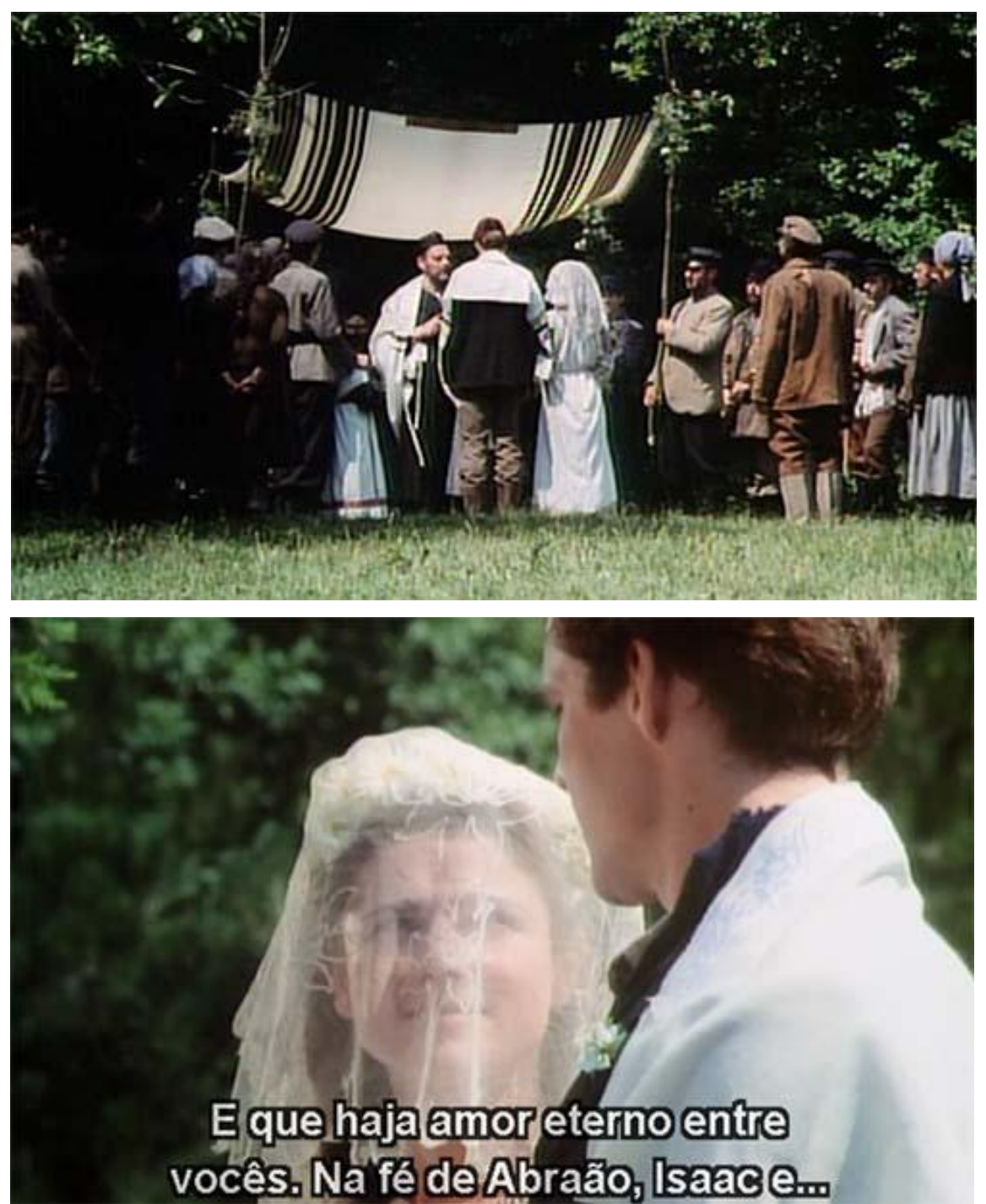

Figura 11 - A celebração de caráter eminentemente judaico no matrimônio de Rudi com Helena sinaliza, por meio do rito religioso, o encontro do personagem com sua ancestralidade anteriormente adormecida.

O clima festivo da celebração é interrompido pela repentina chegada de um jovem que alerta a todos sobre a presença de uma patrulha nazista a três quilômetros do local. Rudi, Helena e os outros guerrilheiros fogem para levantar acampamento e partir. A câmera focaliza os cascos de vidro no pano utilizado no ritual da quebra do copo, criando a conexão entre a catástrofe de Jerusalém - cuja memória foi recuperada no ritual - com a catástrofe do Holocausto. 
Karl Weiss, preso em Buchenwald, é o único membro da família que permaneceu na Alemanha e que, sob a difícil posição de encarceramento no campo de concentração, não encontra espaço para qualquer atividade de resistência. Transferido para um trabalho mais leve em uma área destinada aos artistas por conta do acordo prévio entre Inga e Heinz Muller ele é vítima constante da provocação e do escárnio do funcionário nazista. Neste ponto do enredo o enfoque da trama está situado muito mais nos sofrimentos do par romântico separado pelas circunstâncias e na atuação do oponente vilão nazista do que propriamente na reconstrução histórica dos eventos. A fidelidade matrimonial de Inga, sacrificada para que Karl pudesse continuar vivo e receber suas cartas, é o grande conflito amoroso do personagem.

O destino de Karl é alterado com sua transferência para o campo de concentração de Theresienstadt, na República Tcheca, junto a Otto Felscher, outro artista judeu encarcerado no campo. A conexão criada aqui entre o trabalho artístico de Karl e a narrativa histórica faz referência à vida cultural de Theresienstadt ${ }^{93}$, misto de campo de concentração e gueto que se notabilizou pela produção artística de seus prisioneiros. Com condições de acomodação e alimentação menos piores comparado a outros campos e guetos judeus da Polônia, este campo de concentração era utilizado pelos nazistas para divulgar para a Cruz Vermelha e para a comunidade internacional as "boas" condições que a administração alemã reservava aos judeus. Ao incluir a passagem de Karl em Theresienstadt, o roteirista Gerald Green também adicionou ao enredo as experiências reunidas em seu livro "The Artists of Terezin" (1969), que serviu de base para várias cenas do campo tcheco apresentadas na minissérie ${ }^{94}$.

Karl e Otto Felscher são recepcionados em Theresienstadt por Maria Kalova, uma das artistas encarceradas, que os conduz para o estúdio onde os trabalhos são produzidos. Os recém-chegados se surpreendem pelo cenário aparentemente aprazível do lugar e pela presença de lojas, bancos e um café. Maria Kalova rapidamente

\footnotetext{
${ }^{93} \mathrm{O}$ "campo-gueto" de Theresienstadt, na República Tcheca ocupada, existiu durante três anos e meio, de novembro de 1941 a maio de 1945. Iniciou suas funções como um campo de trânsito para judeus tchecos deportados a campos de extermínio na Polônia e campo de trabalho para judeus alemães, austríacos e tchecos idosos e incapacitados. Neste último caso, os nazistas utilizaram o campo em sua propaganda para a comunidade internacional sobre o "tratamento humanitário" reservado aos judeus. Apesar das péssimas condições de vida do local, Theresienstadt desenvolveu diversas atividades culturais, resultado da presença de renomados artistas judeus que foram encarcerados ali.

Disponível em: http://www.ushmm.org/wlc/es/article.php?ModuleId=10007630 . Acesso em 14.07.2014

${ }_{94}$ INSDORF, Annete. Indelible Shadows: film and the Holocaust. New York: Cambridge University Press, 1989, p. 149.
} 
esclarece que tal estrutura foi criada pela administração nazista para iludir os visitantes da Cruz Vermelha. Os barracões repletos de velhos doentes e uma prisão onde torturas e assassinatos são comuns demonstram que não há diferença entre Theresienstadt e Buchenwald. O rápido diálogo entre Maria Kalova e os novos prisioneiros recupera mais uma vez a reação da comunidade internacional a respeito do tratamento dispensado aos judeus durante o Terceiro Reich. Felscher questiona o sentido de tal encenação para a Cruz Vermelha, e Maria Kalova responde que para os nazistas este campo de concentração se trata de um "passaporte para a respeitabilidade": "verá quando chegar a Cruz Vermelha e decidir que os nazistas tratam os judeus com amabilidade. Os suecos, os suíços, todos os países neutros nos visitam. Ah, um banco e uma padaria, um cinema! Por que os judeus reclamam tanto?". Karl questiona se as pessoas acreditam na encenação, e Otto Felscher conclui: “talvez eles prefiram acreditar”.

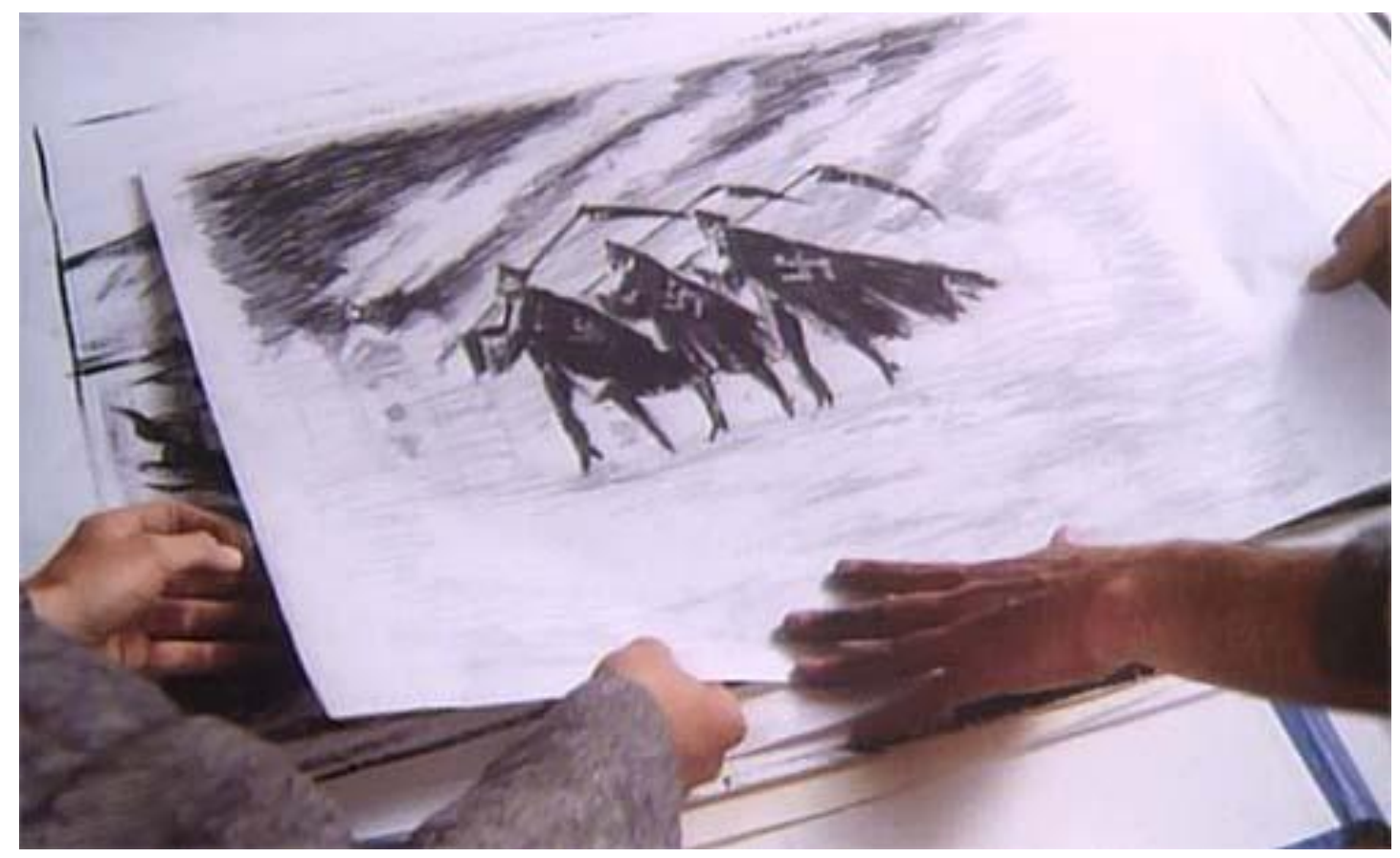

Figura 12 - A atuação de resistência de Karl Weiss manifesta-se na expressão artística dos desenhos que denunciam a brutalidade nazista em Theresienstadt.

Ao verificar os trabalhos produzidos por seus companheiros de encarceramento em Theresienstadt ele observa que as reproduções em desenhos de crianças brincando, as comidas do Shabat e o aspecto positivo do gueto retratado pelos artistas não reflete a realidade da ocupação nazista. É então que Emil Frey, um dos artistas reunidos no 
estúdio, revela que há também ali alguns desenhos que retratam, com uma representação gráfica mais próxima da realidade, as péssimas condições de vida da população judaica do campo de concentração. Frey retira de um vão secreto sob a parede do edifício uma série de desenhos a lápis retratando prisioneiros subnutridos e arame farpado, idosos amontoados em vagões de trem e nazistas personificados como anjos da morte. Os desenhos que Frey mostra a Karl fazem referência ao trabalho dos artistas judeus prisioneiros Leo Haas e Karel Fleischmann, que registraram o testemunho sobre as precárias condições de vida em Theresienstadt em suas pinturas e litografias. Dentro dos traços de fragilidade e sensibilidade de seu personagem que o posicionam no polo da passividade em relação às perseguições nazistas, este momento marca a única possibilidade de envolvimento de Karl com alguma atividade de resistência que será concretizada através de sua produção artística.

De acordo com o discurso do teledrama, a decisão pelo uso do gás no extermínio dos judeus está não apenas vinculada à busca por maior eficácia no extermínio de um amplo contingente populacional, mas também nas disputas internas entre os líderes do partido nazista, núcleo narrativo em que estão presentes o personagem fictício Erik Dorf e figuras históricas do nazismo. Desta forma, a presença de Heinrich Himmler em uma cena apresentando o massacre de um grupo de judeus por fuzilamento em um ponto qualquer da Europa Oriental funciona como mote explicativo que influenciará na procura por métodos de assassinato em massa mais eficientes. Tal cena recupera um episódio real no qual Himmler foi convidado por Arthur Nebe, outro membro da SS, a assistir a execução de um grupo de judeus nas proximidades de Minsk. Segundo o relato historiográfico, o comandante supremo da SS vomitou após testemunhar as execuções tendo solicitado ao próprio Nebe e à Heydrich a busca por outras formas de assassinato em massa. Na representação desta cena na minissérie, a reação de Himmler é utilizada por Erik Dorf não apenas para provocar Paul Blobel e o próprio Arthur Nebe claramente desafetos do major da SS - a respeito da ineficácia de seus métodos como também como uma oportunidade de obter vantagens em sua carreira na busca por métodos alternativos de execução.

A busca de Dorf o leva novamente à Polônia, onde ele presencia alguns experimentos de asfixia de um grupo de judeus por monóxido de carbono produzido por um motor de um furgão cujo escapamento era redirecionado para o interior do veículo. Tal método, conforme aponta a historiografia, foi utilizado não só no extermínio dos 
doentes mentais e prisioneiros soviéticos como também nas primeiras etapas na execução em massa de judeus por gás na região do Warthegau, na Polônia ocupada ${ }^{95}$. Tal experimento, apesar do avanço representado em relação às mortes por fuzilamento, não alcançou a eficácia desejada. Em meio às disputas internas com seus inimigos da SS, Erik Dorf explicita sua insatisfação afirmando que é possível fazer algo melhor utilizando o conhecimento dos químicos alemães. O personagem novamente reafirma sua importância em momentos cruciais das decisões nazistas, criando um vínculo com a decisão final do melhor método para aniquilar a população judaica europeia.

Mesmo contribuindo com suas sugestões e ideias para a racionalização do processo de extermínio, Erik Dorf inicia sua derrocada que é ao mesmo tempo o declínio do regime nazista e de suas ilusões de superioridade racial. O fim das ilusões de Erik, confirmado com a derrota do Eixo na Guerra e a sua prisão também representará o fim das ilusões do povo alemão, o que tem relação direta com sua responsabilidade diante dos crimes perpetrados durante o Terceiro Reich.

Nesta etapa do enredo, a logística do extermínio e as etapas para o seu processo são detalhados. Em uma uma reunião de rotina, Erik informa seus superiores sobre a insuficiência dos campos de extermínio de Belzec, Chelmno e Treblinka na tarefa de "tratamento especial" dos judeus para lá enviados. Além de Himmler e Heydrich um outro líder histórico nazista é apresentado na cena: Rudolf Höss. A presença de Höss tem relação com a primeira menção feita a Auschwitz na minissérie. Nesta reunião Himmler e Heydrich instruem Höss e Dorf sobre as funções do complexo de Auschwitz. O ainda futuro comandante de Auschwitz explicita sua disposição em obedecer e servir.

Em uma noite de insônia em que Marta o questiona sobre as razões de suas inquietações, Erik revela a ela que a guerra está perdida e que a entrada dos americanos no conflito, reforçando o esforço militar dos aliados, selou o destino do Terceiro Reich. As angústias de Erik têm relação com as tarefas burocráticas relacionadas com o extermínio dos judeus cuja coordenação é sua responsabilidade. Por não poder revelar à esposa os detalhes de tais obrigações e antevendo que a verdade será revelada com a derrota da Alemanha ele a orienta sobre o que o futuro dirá sobre as ações nazistas no leste da Europa: "Querida, um dia contarão mentiras horrendas sobre o que fizemos na Polônia e na Rússia. Tentarão forçar que os escute e se fizerem dirá a si mesma e às

\footnotetext{
${ }^{95}$ FRIEDLÄNDER (2012, vol. 2). op. cit. p. 293.
} 
crianças que eu sempre fui um fiel servidor do Reich. Um homem honrado que não fez mais que obedecer ordens. Ordens dos mais altos comandos”.

Marta, que de fato é a grande influência sobre as ações do marido desde o início de seu envolvimento com a oficialidade nazista, o estimula a não falar em derrota e à manter a crença em suas próprias funções. O desânimo de Erik é uma demonstração de sua fraqueza inicial de cidadão comum cuja filiação tardia aos ideais do partido nazista revela uma fé pouco enraizada em relação à sua ideologia. Gerenciar o processo de extermínio com o vislumbre da derrota futura torna sua tarefa mais difícil. Cabe a Marta incentivá-lo a manter sua convicção em suas obrigações afirmando que ele é melhor do que Hans Frank, Rudolfo Höss e todos altos comandantes nazistas. As angústias pessoais de Erik Dorf ganham, no entanto, um novo componente. Nesta mesma noite de insônia e desabafo, uma ligação telefônica o informa que Reinhard Heydrich sofreu um atentado em Praga e que está à beira da morte ${ }^{96}$, o que termina por ocorrer alguns dias depois. Ao ser informada a respeito do estado crítico de Heydrich e da possibilidade de que ele talvez não sobreviva ao atentado, Marta rapidamente orienta o marido a ser mais agressivo e aproveitar a possível oportunidade de sucedê-lo no cargo.

A preparação para o Levante do Gueto de Varsóvia começa a tomar forma no início do episódio. Moses e Aaron saem clandestinamente do gueto para encontrar-se com membros da resistência polonesa que fornecerão armas para os resistentes judeus. De maneira explícita, a própria fala dos personagens menciona a referência aos personagens bíblicos Moisés e seu irmão Aarão, o primeiro sumo-sacerdote dos hebreus. Joseph mostra-se preocupado pela decisão de Moses de arriscar-se na missão, e o farmacêutico justifica dizendo que é melhor que os resistentes percam um homem velho do que um jovem soldado. Além disso, afirma ele, “quem poderá deter Moisés e Aarão?". Rememorando o protagonismo dos profetas bíblicos na partida dos judeus da escravidão do Egito para a terra prometida de Canaã, Moses e Aaron participam ativamente das atividades de resistência no Gueto de Varsóvia.

O encontro dos resistentes do gueto com a resistência polonesa tem como função mostrar a pouca disponibilidade de outros grupos de resistência ao nazismo de colaborar com os resistentes judeus. Ao encontrar-se com Anton, um dos membros do grupo

\footnotetext{
${ }^{96}$ Em 27 de maio de 1942, Heydrich foi ferido gravemente em um atentado efetuado por combatentes tchecos que, com auxílio britânico, saltaram de paraquedas no então Protetorado da Boêmia e Morávia. O comandante nazista veio a falecer em 4 de junho. FRIEDLÄNDER, op. cit., p. 429.
} 
polônes, Moses entrega a ele o dinheiro para a aquisição de doze pistolas. Anton responde que com aquele montante só é possível comprar uma arma e nenhuma munição. Moses protesta, mas o polonês responde que se ele não estiver interessado não precisa fechar o acordo. Moses afirma que apenas quer a colaboração da resistência polonesa já que eles enfrentam o mesmo inimigo. Os poloneses seguem em silêncio e pouco dispostos a negociar e o farmacêutico judeu acaba partindo com apenas uma pistola. Um deles revela que não confia em judeus, complementando com a assertiva: “judeus não lutam”.

A cena seguinte nega a afirmação do resistente polonês ao apresentar os membros da resistência do gueto reunidos com Mordechai Anielewicz em um treinamento de tiro ao alvo. O líder apresenta ao grupo a única pistola obtida por Moses na negociação com a resistência polonesa, detalhando seus componentes e simulando um treino de tiro ao alvo com um grupo de jovens judeus. Aaron é o voluntário escolhido por Anielewicz para representar a simulação em que o alvo é a suástica nazista. Aaron mira o alvo, aperta o gatilho, e o grupo o aplaude. Ao fundo uma bandeira sionista marca presença no quartel general dos resistentes.

A narrativa informa neste episódio qual foi o destino do padre Lichtenberg, personagem histórico que ousou denunciar a perseguição aos judeus no Reich. Ao visitar a igreja, Inga é informada pelo novo padre que o substituiu sobre a detenção do religioso e de seu envio para o campo de concentração de Dachau. O novo pároco culpa o próprio Lichtenberg por seu lamentável destino: "era um sacerdote teimoso, todos diziam a ele: 'esqueça dos judeus, eles não são problema nosso', mas ele continuou a falar". A câmera focaliza, na mesma sala, dois retratos em perfil do padre Lichtenberg e do papa Pio XII. O posicionamento dos perfis, um de frente para o outro em clara conotação de confronto, faz referência ao papel da igreja católica e do Vaticano em relação aos judeus durante o Terceiro Reich. A coragem e estatura moral do padre Lichtenberg na defesa dos judeus contrasta com a suposta omissão do pontificado de Pio XII em relação aos mesmos judeus. No que concerne à atuação de Pio XII no tocante aos ataques do regime nazista, o historiador Saul Friedländer menciona que o pontífice chegou a expressar alguma crítica sobre a perseguição aos católicos na Polônia e a eutanásia dos doentes mentais. "No entanto, em ambos os casos, assim como em 
outros, nada era dito sobre a perseguição aos judeus" ${ }^{\text {"97 }}$. Esta imagem da minissérie procura reforçar o protagonismo de membros isolados da igreja católica no esforço de defesa da comunidade judaica sem ignorar a política de apaziguamento do Vaticano que não permitiu uma declaração mais enfática de repúdio aos massacres nazistas contra os judeus.
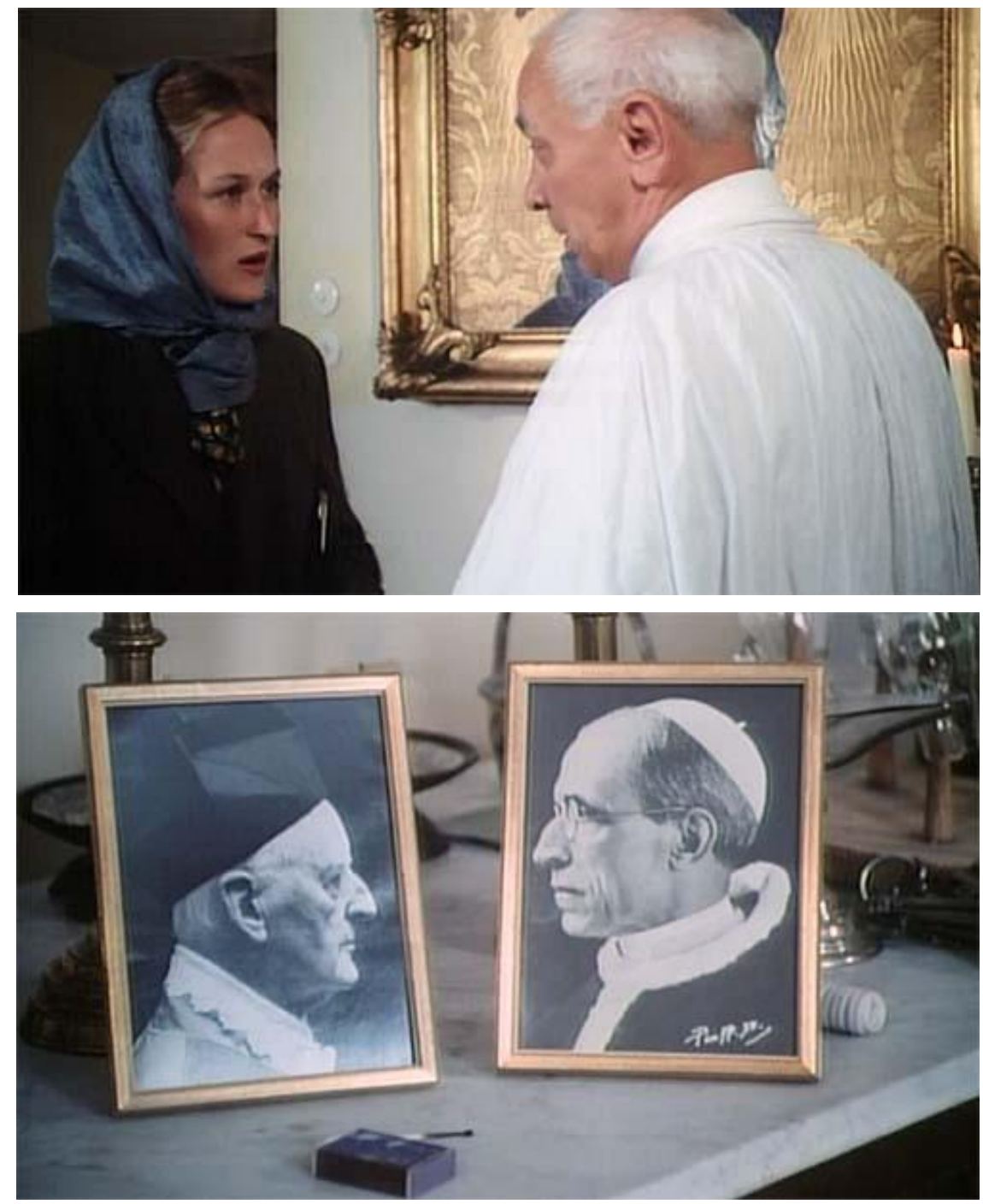

Figura 13 - As fotografias do padre Lichtenberg e a do Papa Pio XII, posicionadas em evidente confronto, reforçam a comparação entre a coragem do primeiro e a omissão do segundo, sob a ótica do teledrama.

No núcleo do comando nazista, após a morte de Heydrich, Erik Dorf inicia seus esforços para ser reconhecido como seu sucessor natural. A atuação de Dorf em

\footnotetext{
${ }^{97}$ FRIEDLÄNDER (2012, vol. 1). op. cit. p. 111.
} 
decisões-chave do comando nazista nas etapas burocráticas do processo de extermínio ressurge novamente, agora através da decisão de utilizar o Ziklon B para o envenenamento dos judeus nos campos de extermínio. Novamente a ficção é a chave para conhecidas decisões históricas. Dorf é convencido da eficácia do pesticida por um químico que reforça a praticidade do produto em relação ao monóxido de carbono, reiterando de maneira implícita os rumores sobre o envenenamento de judeus por meio deste mecanismo. Desta forma, é Dorf, o personagem fictício, que ordena a Rudolf Höss a aquisição do produto responsável pela morte de milhares de judeus em Auschwitz e outros campos da morte poloneses.

Os planos de Erik Dorf são frustrados quando o regime decide substituir Reinhard Heydrich por Ernst Kaltenbrunner, pouco permeável às sugestões e influências do major carreirista. Na verdade, Kaltenbrunner é apresentado como um antigo opositor de Heydrich e sua postura em relação a Dorf é de antipatia explicita. De maneira evidente o major percebe que a proteção anterior como assistente de Heydrich deixou de existir e que no novo cenário é necessário provar eficiência e lealdade ao novo chefe. Oportunamente Kaltenbrunner o encarrega de uma missão, mostrando a ele desenhos produzidos pelos artistas de Theresienstadt (Karl, Felscher e Frey) retratando o cotidiano e as péssimas condições de subsistência no campo de concentração. Em uma cena posterior o espectador é informado de que os desenhos foram contrabandeados para fora do campo de concentração tcheco por Felscher, que trocou algumas das obras por cigarro. Dorf é encarregado de descobrir quem produziu tais desenhos que explicitam a farsa da encenação de Theresienstadt para a Cruz Vermelha Internacional como um campo modelo.

Felscher revela a Karl e Frey que vendeu os desenhos para guardas tchecos e eles se desesperam diante da reação da Gestapo caso tais ilustrações cheguem às mãos da polícia nazista. Karl e Maria Kalova duvidam da eficácia da tímida atividade de resistência dos artistas do gueto já que continuamente os judeus do local são deportados para a Polônia. O clima tenso é quebrado com a chegada de um visitante inesperado. Trata-se de Inga, que finalmente reencontra Karl, juntando-se a ele em Theresienstadt. Informada por Heinz Muller de que Karl fora transferido para o campo tcheco após saber das circunstâncias da prisão do padre Lichtenberg em Dachau, Inga tem a idéia de se fazer encarcerar para reencontrar o ex-marido. Ela pede a Müller que a denuncie à Gestapo e que ele a ajude para que ela seja enviada especialmente para Theresienstadt. 
A licença poética do enredo permite que o artificio tenha resultado e o casal é finalmente reunido.

O reencontro de Karl e Inga recupera o conflito dramático em que fidelidade, honra e sacrifício são colocados à prova pelos personagens. Aqui a narrativa histórica é apenas o pano de fundo para os dramas pessoais da ficção. Karl compreenderá as decisões da esposa que se entregou a outro homem para que ele pudesse continuar vivo em Buchenwald? Inga compreenderá a resistência do marido em aceitá-la de volta? O drama central do casal formado pelo artista judeu e pela jovem ariana cumpre sua função de manter a atração do público telespectador. Parece menos importante saber o destino dos milhares de judeus vítimas da implacável máquina nazista (algo que a própria narrativa histórica já se encarregou de detalhar) do que o futuro do desafortunado par romântico da ficção. A resistência de Karl em aceitar as explicações de Inga por ter se entregado a Heinz Müller não se sustenta por muito tempo e ele termina por perdoar a esposa, embora esteja descrente de que não sobrevirá a guerra devido à determinação dos nazistas em aniquilar os judeus. Inga o reconforta: "Você está vivo. Lembro-me de quando seu pai foi deportado para a Polônia. Ele beijou sua mãe e disse que, independente do que acontecesse 'amor omnia vincit', o amor tudo vence". A frase retirada dos versos de Virgílio conclui a cena de reconciliação do casal reforçando a superioridade do amor sobre o infortúnio, dentro do esquema melodramático que é próprio à narrativa.

No Gueto de Varsóvia um oficial da SS ordena ao conselho judaico, representado na cena por Joseph, Moses e o Doutor Kohn, de que estes devem fornecer o contingente de seis mil judeus por dia para serem deportados. Joseph questiona o oficial sobre como irão selecioná-los e o que dirão a eles para que cooperem com a deportação. A resposta do oficial segue o mesmo discurso oficial imbuído dos artifícios utilizados pela administração nazista para convencimento dos judeus: "Digam a verdade a eles. Que serão transferidos para campos de família na Rússia". Tais campos de trabalho, segundo o oficial, proporcionam ar puro, boa comida e a possibilidade de manter as famílias unidas. Ciente de que a explicação do oficial é apenas um disfarce para um destino pior do que o próprio gueto, Joseph o adverte: "as pessoas podem resistir". O SS responde com a confirmação, do ponto de vista nazista, da passividade dos judeus diante de seu próprio infortúnio: "seu povo não resistiu ainda". 
A resistência começa a tomar forma a partir do momento em que os rumores sobre o destino dos deportados são finalmente confirmados. Friedrich Zalman, um dos combatentes do gueto, é enviado pela resistência em um dos trens com destino aos campos familiares russos mencionados pela SS. Em seu retorno ele relata a Moses o que acontece com os judeus deportados:

MOSES: O que você descobriu?

ZALMAN: Os trens não vão para a Rússia.

MOSES: Para onde vão?

ZALMAN: Para Treblinka, a três horas daqui.

MOSES: Treblinka? Outro campo de trabalho polonês?

ZALMAN: É um campo de morte. Os poloneses cristãos vão para o campo de trabalho. Os judeus saem dos trens para um grande edifício. A SS diz que é para desinfecção.

MOSES: É o que suspeitávamos?

ZALMAN: Os banheiros têm toalhas, saboneteiras e instalações sanitárias que nunca funcionaram. Falam que depois do banho irão para o trabalho mas eles nunca saem, são mortos com gás.

MOSES: Seis mil por dia?

ZALMAN: Família inteiras, mães com seus filhos, idosos.

MOSES: Você sempre teve razão. Perdoe-me por ter duvidado.

Friedrich Zalman foi designado para esta missão por conta de suas conexões com as organizações de resistência judaicas posicionadas clandestinamente no lado ariano de Varsóvia e pelo fato de que este poderia facilmente se passar por um polonês $^{98}$. De fato a informação dada por Zalman foi passada a ele por Uziel Wallach, outro judeu que conseguiu escapar de Treblinka e o informou sobre os detalhes do que

\footnotetext{
${ }^{98}$ GUTMAN, Ysrael. The Jews of Warsaw. 1939-1943: Ghetto, Underground, Revolt. Indiana University Press, 1989, p. 222.
} 
havia registrado no campo de extermínio. A minissérie reconstrói parte do registro de Wallach relatado a Zalman.

A confirmação do extermínio sistemático dos judeus por gás em Treblinka é submetida pelo membro da resistência judaica para os aliados no exterior mas nenhuma medida é tomada para interromper o fluxo de deportações em direção aos campos da morte. Novamente a narrativa reforça a parcela de responsabilidade dos aliados sobretudo em relação à postura omissa uma vez que os rumores sobre os massacres caminham para a confirmação. Tal reforço é representado em uma cena em que os membros da resistência conseguem sintonizar, com um aparelho de rádio improvisado, as emissões da BBC sobre as últimas notícias da guerra:

LOCUÇÃO DA BBC: A campanha britânica no norte da África está triunfando. Mais cinco cidades na fronteira entre a Líbia e a Tunísia renderam-se à entrada do oitavo exército. Foi realizado um total de 141 vôos de aviões aliados sobre a França e os Países Baixos nas últimas 24 horas. Fontes das forças de resistência polonesa informam que as tropas nazistas estão cometendo atrocidades contra a população polonesa, incluindo o fuzilamento da população civil. E aqui termina este boletim de notícias da BBC de Londres...

MOSES: Fuzilamentos da população civil? Há semanas que sabem sobre Treblinka, câmaras de gás, liquidação dos guetos e nenhuma palavra da BBC!

ANIELEWICZ: Agora você entende porque somos sionistas?

MOSES: Talvez não acreditem no que contamos.

ANIELEWICZ: Não dá para acreditar em um judeu.

A descrença em relação à cooperação com as forças aliadas para interrupção das deportações e consequentemente aniquilação dos judeus deportados reitera a necessidade dos combatentes do gueto de não contar com qualquer ajuda externa para seus planos de revolta. Os judeus devem contar apenas com sua própria comunidade e Anielewicz procura justificar a base de sua crença no sionismo exatamente pela impossibilidade de que exista alguma fraternidade genuína das outras nações em relação aos judeus, ao menos na circunstância da guerra e do Terceiro Reich. Neste momento a 
narrativa parece apontar que a principal fraternidade deve ocorrer apenas nos limites internos da própria comunidade perseguida.

Se a resistência aos nazistas não passa pela revelação ao mundo das atrocidades cometidas por esses, ela deve vir do combate direto. Zalman afirma que só há uma solução: contrabandear mais armas. Anielewicz encarrega Moses de contactar a resistência polonesa. Joseph sugere salvar alguns dos deportados instalando uma clínica na estação de embarque com o intuído de impedir a partida dos judeus selecionados por ele como inaptos à viagem por motivo de doença. A resposta de Anielewicz para esta sugestão é categórica: "Sim, talvez salvemos alguns. Mas a resposta são as armas”.

A clínica de Joseph é instalada nas proximidades da plataforma de embarque para a deportação. De avental branco e carregando um estetoscópio o médico judeu se aproxima de alguns dos deportados e os examina rapidamente, ordenando a alguns deles que entrem na clínica com a justificativa de que estão doentes e não podem viajar em tais condições. $\mathrm{O}$ dispositivo ficcional utilizado aqui baseia-se parcialmente na figura histórica de Nachum Remba, um funcionário do Conselho Judaico do gueto que chegou a criar um posto de auxílio médico próxima à plataforma de embarque dos deportados. ${ }^{99}$

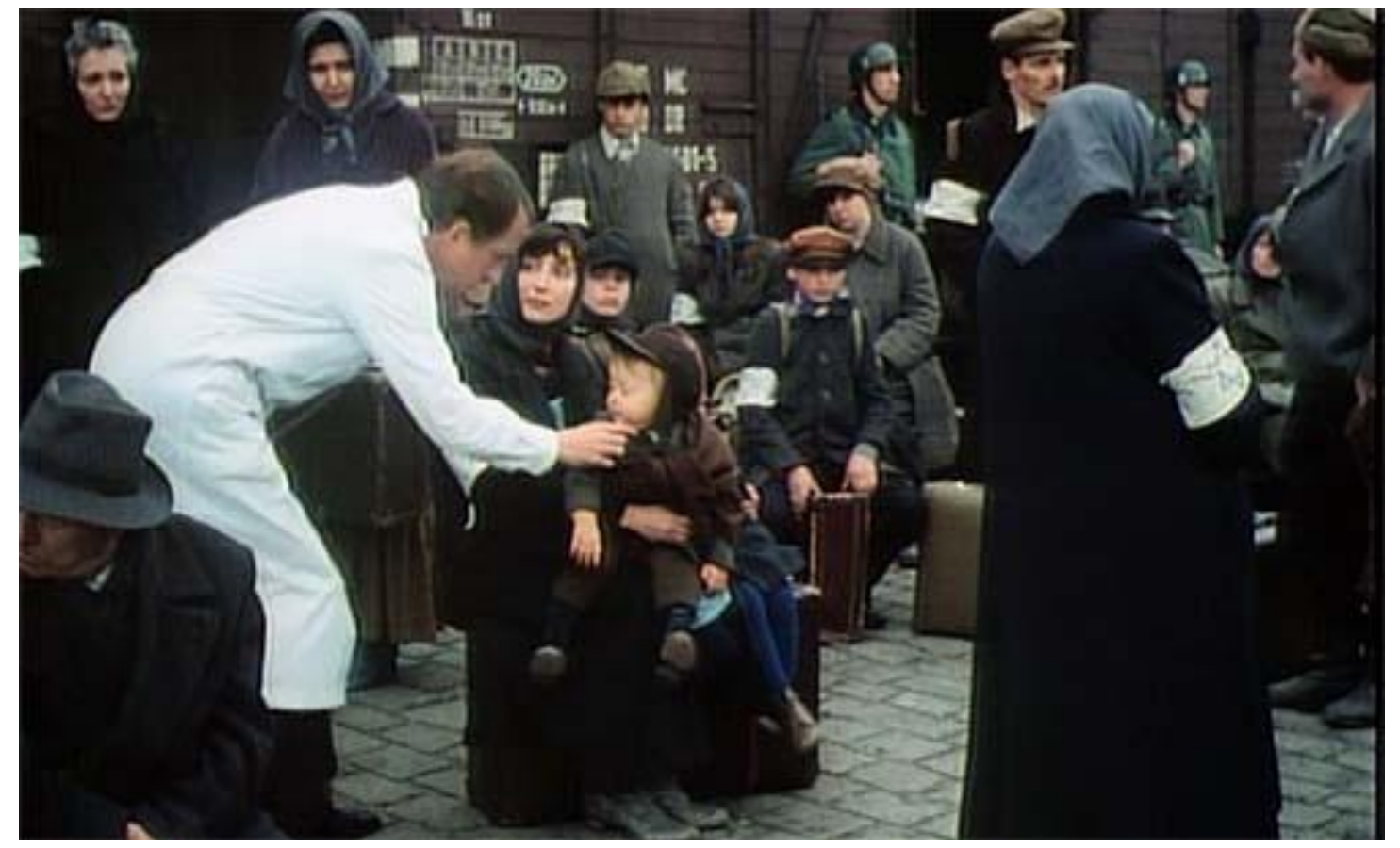

Figura 14 - Joseph Weiss adia a deportação de judeus do Gueto de Varsóvia antes de seu embarque para o extermínio em Treblinka. As ações de resistência do médico, embora baseadas em um personagem histórico, fazem também um contraponto à conhecida seleção do médico nazista Joseph Mengele em Auschwitz-Birkenau.

\footnotetext{
${ }^{99}$ GUTMAN, Ysrael. op. cit, p. 209
} 
As ações de Joseph Weiss, inspecionando aleatoriamente alguns dos deportados em espera para o embarque e direcionando-os para a clínica com o intuito de salvá-los do extermínio contrasta claramente com as conhecidas ações de Josef Mengele e outros médicos de Auschwtiz, que selecionavam os recém-chegados ao campo de extermínio indicando os aptos ao trabalho para a direita e os destinados à câmara de gás para a esquerda $^{100}$. A seleção de Joseph, cuja eficácia é de mínimo alcance por representar apenas um adiamento às deportações futuras, tem como função reforçar o seu modo de resistência e o heroísmo necessário ao personagem para as funções discursivas do teledrama. A resistência não é medida aqui pela sua eficácia numérica, mas apenas pelo fato de sua própria ocorrência, o que denota a não colaboração com os algozes.

O foco de resistência em Theresienstadt em que Karl Weiss é um dos participantes é desmantelado pela Gestapo. Seguindo as ordens de Kaltenbrunner, Erik Dorf se reúne com Adolf Eichmann e Karl Rahm, comandante do campo tcheco, para interrogar Karl, Frey e Felscher e descobrir a origem dos desenhos produzidos ali e contrabandeados para fora. As tímidas ações de resistência de Karl, concretizadas nas produções dos desenhos, agora ganham um novo significado pois será necessário manter o segredo sobre as outras litografias produzidas e não revelar aos oficiais e agentes da polícia nazista de que maneira eles ultrapassaram os muros do campo de concentração. O interesse desta análise está no diálogo entre Karl e Erik. O oficial nazista, em uma conversa privada com o artista judeu, demonstra saber que ele é o filho de seu antigo médico de Berlim, a quem ele negou ajuda para libertar da prisão antes da guerra. O diálogo reproduzido abaixo evidencia a percepção de Karl sobre sua nacionalidade alemã revogada pelo nazismo:

ERIK - Tenho a impressão de que nos conhecemos, certo?

KARL - Eu não me lembro

ERIK - De berlinense para berlinense, esqueça dos tchecos e austríacos.

KARL - Os berlinenses me mantiveram em Buchenwald durante quatro anos. Os berlinenses enviaram meus pais para Varsóvia.

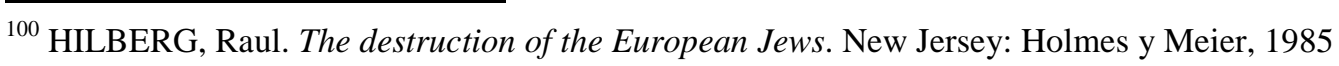


ERIK - Este é o mal dos judeus, que não esquecem o passado. Estes desenhos significam muito para mim. Você tem uma esposa cristã, podíamos facilitar algo.

KARL - Nos libertar?

ERIK - Podemos arranjar isso. De outro modo lhe entregarão a Rahm e sua mulher não desejará ver você quando terminarem.

KARL - Não há mais conspiração. Não há mais desenhos...

Erik tenta estabelecer um elo de ligação entre ele e Karl apelando para um passado comum como berlinense para obter a informação de que precisa sobre a origem dos desenhos e angariar a simpatia de Kaltenbrunner. Ao afirmar que os berlinenses foram responsáveis por sua prisão em Buchenwald e pela deportação de seus pais, Karl recusa sua identidade berlinense e alemã, colocando-se em oposição a tal cidadania. $O$ arranjo proposto por Erik é negado por ele, que insiste em dizer que não há conspiração e que outros desenhos não foram produzidos. O heroísmo e a preservação do caráter de Karl contrastam com a tentativa fracassada e dissimulada de Erik de fazê-lo crer que seu casamento com uma ariana poderia favorecê-lo de alguma forma. Como resultado de sua opção os três artistas do campo de concentração são enviados a prisão e torturados. Felscher é o primeiro a sucumbir ao suplício, morrendo após a primeira sessão. Karl e Frey são severamente torturados e têm seus dedos esmagados, o que os torna inaptos para o trabalho artístico. Posteriormente Frey também termina como vítima fatal da tortura. Apenas Karl sobrevive e retorna a Theresienstadt apenas para despedir-se de Inga antes de sua deportação para Auschwitz. Na despedida ela revela que está grávida. Karl pede a ela que faça um aborto já que não desejaria que seu filho conhecesse o inferno do campo de concentração. Inga se nega a fazê-lo e o faz lembrar das palavras de um rabino: "toda vida humana é sagrada pois é uma centelha divina".

Marta Dorf descobre as verdadeiras funções de Erik em suas viagens à Polônia, e a sua confirmação a respeito dos processos envolvendo o extermínio da população judaica procura refutar a suposição de que os alemães, mesmo aqueles mais próximos aos membros da SS envolvidos nas matanças, desconhecessem o real destino dos judeus deportados. A descoberta a respeito desses crimes no entanto só reforça sua convicção de que Erik deve prosseguir com suas tarefas da maneira mais eficiente possível para agradar Kaltenbrunner e não arruinar sua carreira. Ao dizer ao marido para orgulhar-se 
de suas funções e cumprir as ordens até o final, mesmo antevendo a derrota alemã, ela assume que este é um caminho sem volta. Marta representa a consciência pública alemã que aderiu rapidamente ao nazismo em nome dos benefícios obtidos por tal adesão, tendo ciência do fato de que a população judaica estava claramente sendo exterminada. Ela decide destruir as cartas que possibilitaram a confirmação dos crimes cometido. Sua fala resume de alguma forma a postura dessa parcela de alemães que foi conivente com o extermínio mas que procurou apagar da memória o seu envolvimento: “essas cartas, as pessoas nuas, as câmaras de gás, as piras funerárias, vou me livrar delas para que ninguém saiba, para que não digam mentiras sobre você".

Os detalhes descobertos por Marta são apresentados ao telespectador logo em seguida. A cena reconstrói a entrada de um grupo de prisioneiros em uma câmara de gás durante a visita de um higienista da Universidade de Marburg, o professor Otto Pfannenstiel, acompanhado por Erik Dorf e Rudolf Höss. Tal cena é baseada em um episódio verídico já que o professor Pfannenstil, assim como Höss, é um personagem histórico. Na verdade, Pfannenstiel visitou o campo de extermínio de Belzec, local em que a operação de asfixia ainda era feita com motores a diesel que produziam o monóxido de carbono para asfixiar as vítimas. A cena é baseada nos relatos de Pfannenstiel e Kurt Gerstein, especialista em assepsia da Waffen-SS ${ }^{101}$. Na minissérie, Pfannestiel visita uma das várias câmaras de gás do complexo de Auschwitz.

Uma orquestra de prisioneiras toca composições de música erudita enquanto as dependências do complexo são apresentadas ao higienista. A cena tem como função apresentar ao telespectador os detalhes logísticos do processo, e assim o professor é levado a conhecer os fornos crematórios em funcionamento e sua capacidade, além de inspecionar as duchas no interior da câmara de gás que liberam o Ziklon B. O professor assiste a um grupo de prisioneiros despindo-se para a "desinfecção" que imediatamente é encaminhado para a câmara de gás. O oficial da SS responsável os tranquiliza, reproduzindo o artifício utilizado para convencer os judeus a serem mortos: "é apenas um banho. Cinco minutos, nada mais. Vocês ficarão limpos e livres de piolhos". Na parte superior do edifício outro oficial da SS introduz os cristais de Ziklon B por uma chaminé. Através de um olho-mágico na porta da câmara de gás o professor Pfannestiel testemunha os últimos momentos das vítimas e ouve seus gritos e lamentações: “...como

${ }^{101}$ FRIEDLÄNDER, Saul (2012, vol 2). op. cit., p. 552 
uma cena do Inferno de Dante. E os sons são quase como os lamentos de uma sinagoga".

Os atos heroicos de Joseph e Berta Weiss em Varsóvia são interrompidos quando a SS, ao descobrir a não existência de uma permissão oficial para o funcionamento da clínica de Joseph, ordena o fechamento e a destruição do local. Todos os envolvidos na ação clandestina devem ser deportados. Um policial judeu vai ao encontro de Berta, que leciona em uma das escolas do Gueto, e a informa de seu destino. O policial se aproxima da sala de aula enquanto a professora, ao piano, ensaia com seus alunos que cantam a "Hatkivah", o hino sionista. A cena recupera não só um momento de afirmação da identidade judaica ligada ao sionismo (reforçando o elo entre os personagens e as ações de resistência de vinculações sionistas de que fazem parte) como também denota um percurso interessante que diz respeito à própria Berta Weiss. A pianista, que no início da narrativa afirmou ter orgulho de sua nacionalidade germânica simbolicamente personificada por figuras do universo musical como Mozart e Beethoven, faz um retorno à sua ancestralidade, devidamente representado na melodia do hino sionista tocada ao piano do Gueto. Berta encontra Joseph, Franz Lowy e sua esposa na plataforma onde embarcam os deportados. Oportunamente, ao contrário do que regularmente acontecia com os trens de deportados de Varsóvia, a composição é desviada para Auschwitz. A mudança é um artifício narrativo do teledrama para que Joseph e Berta sejam enviados para o mesmo lugar que seu filho Karl.

\subsection{Quarto episódio: "The saving remnant"}

No quarto e último episódio de "Holocausto", não só a decisão dos nazistas de aniquilar a população judaica se torna conhecida para os outros personagens judeus como também são apresentados os detalhes técnicos do extermínio. Tal apresentação segue a receita do discurso pedagógico utilizado em toda a narrativa. Desta forma os artifícios utilizados pelos nazistas para encobrir o real destino dos deportados e os métodos utilizados para o extermínio seguem a receita do tom didático costumeiro ao teledrama de maneira a ser facilmente absorvido pelo grande público. Aqui a trajetória da família Weiss finalmente é concluída tendo o campo de extermínio de Auschwitz como o último destino. Apenas Rudi sobrevive, o que explica o título deste último capítulo do teledrama 
Após a deportação de Berta e Joseph algumas ações de resistência marcam o início do Levante do Gueto de Varsóvia. Uma batida policial da SS na busca por armas contrabandeadas acaba provocando a reação dos combatentes judeus, que ao emboscarem alguns soldados da SS, se apoderam de suas armas. O arsenal da resistência tem um incremento em seu esforço de guerrilha e o maior levante em um gueto judeu na Europa ocupada têm início. Moses Weiss é um dos protagonistas da recriação desta reação e a surpresa diante desta ação repentina reverbera o discurso comum da pouca afinidade da comunidade judaica com uma postura combatente, até mesmo bélica. O próprio Moses faz referência a essa percepção, momentos antes de disparar os primeiros tiros contra os soldados da SS: "acho que não convenço como cowboy. Judeus e armas são uma péssima combinação”. Ao verificar os soldados nazistas mortos pelas poucas pistolas e granadas dos resistentes e as metralhadoras obtidas com sua morte, Moses reconfigura seu discurso: “Afinal, existe um Deus! Judeus reagindo". Com as metralhadoras, Zalman, Moses e o jovem Aaron atingem um grupo de reforço enviado para sufocar a ação e finalmente os soldados nazistas são expulsos do gueto. Da janela de um dos edifícios os combatentes assistem, incrédulos, a fuga de tropas nazistas diante de judeus dispostos a lutar antes de sua deportação para o extermínio.

O caráter independente do Levante do Gueto de Varsóvia em relação ao próprio movimento de resistência ao nazismo dos poloneses, já investigado pela pesquisa historica, é não só confirmado pela narrativa fictícia mas recebe um destaque que procura valorizar o empreendimento dos judeus como a única via possível. Tal destaque procurou salientar que os poloneses se mostraram pouco permeáveis a uma aliança com os judeus do gueto e que estes não deviam confiar em tal aliança para obter êxito. Como já vimos anteriormente, os poloneses também compartilhavam a crença de que os judeus eram incapazes de reagir. $\mathrm{O}$ alto valor pago pelas poucas armas obtidas dos poloneses pelos combatentes reforça a pouca disponibilidade destes em apoiar a resistência judaica. Ao responder à pergunta de uma das combatentes a respeito da possibilidade de que os poloneses possam se juntar ao esforço de resistência dos judeus, a fala de Anielewicz reforça essa independência: "não devemos esperar por isso. Meus amigos, estamos por nossa conta". O líder da resistência retira a braçadeira com a estrela de Davi de seu braço esquerdo e exorta seu grupo a fazer o mesmo: "não precisamos mais disso para saber quem somos". A ação de resistência substitui, pela 
decisão de Anielewicz de livrar-se da braçadeira, a marca imposta pelo inimigo nazista. O sinal de identidade judaica é voluntariamente escolhido e tem uma vinculação clara com a postura combatente.

Nas florestas da Ucrânia, Rudi Weiss e o grupo de guerrilheiros seguem engajados em suas atividades de resistência às tropas nazistas. Um ataque a um depósito de armas do exército alemão é preparado pelo grupo, que antes de partir para a ação, recebe a benção do rabino Samuel. Rudi, ainda alheio às peculiaridades religiosas judaicas, assiste ao ritual ao lado de Sacha. Após o término da oração Sacha pede que ele selecione algumas palavras da Torá para ajudá-los. O sacerdote seleciona um trecho do primeiro livro de Samuel: "Davi disse a seus homens: que cada um empunhe a sua espada". A presença da figura religiosa vinculada às atividades de resistência no grupo de guerrilheiros aproxima o caráter inegavelmente religioso da identidade judaica com o espírito de combate e resistência que o discurso da minissérie procura reforçar. Por conta de seus traços semitas pouco perceptíveis, Rudi se disfarça com um uniforme da SS para conseguir entrar no depósito. Sacha o orienta a não hesitar desta vez e ele mata a sangue frio dois soldados que o abordam. Na sequência os guerrilheiros atacam uma taberna no depósito de armas, matando um grande número de soldados e oficiais e se apossando do armamento disponível. Rudi termina gravemente atingido por um dos tiros durante o combate.

Em Auschwitz, Joseph, Berta e o casal Lowy aguardam seu destino. As mulheres são alojadas em um barracão na esperança de serem utilizadas como mão-deobra nas empresas instaladas no local. Joseph e Franz Lowy são levados para trabalhos forçados na construção de uma estrada nas cercanias do campo. Berta recebe a visita de Joseph, que burlando as normas do campo de extermínio, consegue ter acesso à área proibida aos homens. O casal faz promessas caso apenas um dos dois sobreviva:

JOSEPH: Berta, nos prenderam no inferno mas devemos desafiá-los. E tentar viver. Tenho pensado nos rapazes e em Inga.

BERTA: Eu também.

JOSEPH: Algo me diz que estão vivos. Se um de nós morrer aqui o outro deve procurá-los, ficar com eles, amá-los. Sabe o que quero dizer?

BERTA: Sim, eu sei. 
JOSEPH: Não só porque somos uma família, mas também porque somos judeus. Se agrada tanto a eles nos aniquilar, pode ter certeza de que valemos muito e talvez possamos ensinar alguma coisa aos outros.

Aqui a mensagem da tragédia familiar é expandida para o espectro comunitário. O infortúnio dos judeus sob a implacável perseguição nazista que procurou exterminálos deve servir, nas palavras de Joseph, como uma lição a ser compartilhada. Surpreendido pela kapo que supervisiona o alojamento das mulheres, Joseph recebe ordens para deixar o local e o casal tem sua última e rápida despedida.

$\mathrm{Na}$ sequência as mulheres recebem a informação de que devem seguir para o banho e a desinfeção, e pela segunda vez a operação em uma câmara de gás é apresentada ao telespectador. A diferença agora é que o espectador é levado para o interior da câmara de gás, acompanhando Berta Weiss em seus últimos passos. As mulheres recebem a ordem de deixar o barracão em fila e são encaminhadas, entre o desespero e a resignação, para o local da execução. Em seu trajeto um quarteto de cordas formado por prisioneiras executa algumas peças de Mozart. Ao chegarem à antessala da câmara de gás as vítimas recebem ordem para se despir. Durante todo o tempo a supervisora repete que se trata de um banho de desinfecção. Berta, já ciente do artifício, diz a ela que não é necessário enganá-las. Ela fez um último pedido à kapo para que avise Joseph e Franz Lowy sobre o seu destino. Soldados da SS, com sorrisos irônicos, assistem as mulheres nuas se despirem e uma das kapos adentra o recinto trazendo um bebê que uma delas havia ocultado entre os beliches do barracão. "Mães com crianças pequenas! Segurem firmemente seus filhos e peçam que respirem fundo", orienta a kapo. A trilha musical é interrompida e ouve-se apenas o som das mulheres em movimento, o choro das crianças e as ordens emitidas. Prisioneiros judeus entram na antessala da câmara de gás para recolher as roupas das mulheres e um deles é Karl Weiss. Uma fila de mulheres e crianças nuas adentra a câmara de gás e entre elas está Berta. Assim que as portas são fechadas, com uma certa altivez resignada, ela diz sua última fala "Adeus Joseph, eu te amo". 


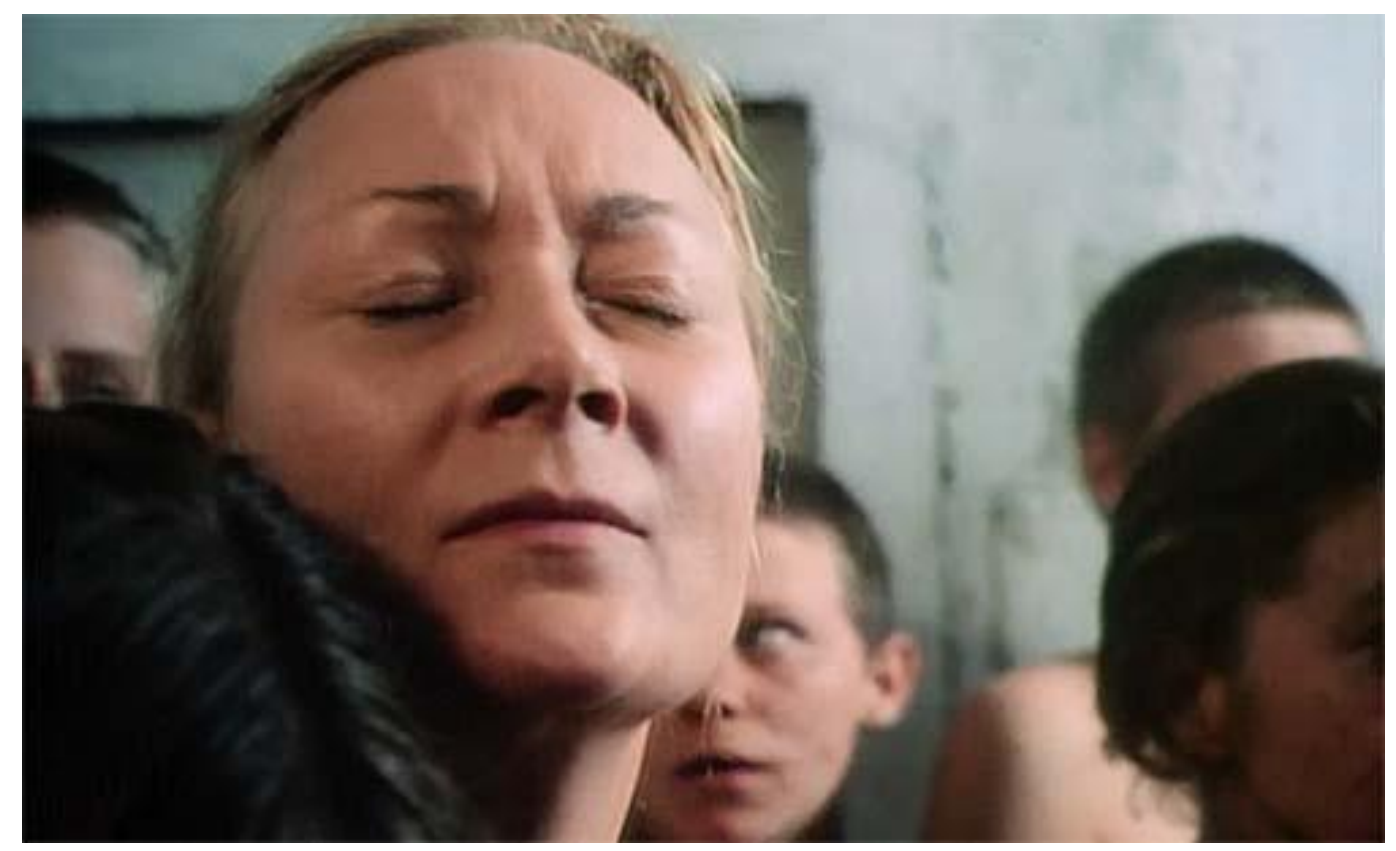

Figura 15 - Berta Weiss aguarda seu destino na câmara de gás. A cena é interrompida neste momento, apontando o limite ético que a representação histórica do teledrama seguiu ao abordar os últimos momentos de grande parte das vítimas dos campos de extermínio.

Há um corte de cena para um fundo negro substituído por imagens das chamas de uma fornalha. Trata-se do forno para o derretimento do piche utilizado para a construção da estrada em que Joseph Weiss e Franz Lowy cumprem trabalho forçado. Novamente as coincidências da trama permitem reunir personagens com ligações no passado e que agora se reencontram em um mesmo cenário. $\mathrm{O}$ engenheiro supervisor da construção da estrada é Kurt Dorf, tio de Erik. Franz Lowy afirma que ele está sendo vigiado pela SS por solicitar muitos prisioneiros judeus nas obras da rodovia e assim livrá-los da morte nas câmaras de gás. Kurt Dorf também não permite que a SS castigue os prisioneiros na sua presença. A postura do engenheiro faz referência ao número não desprezível de alemães que, mesmo tendo simpatia inicial pelo nazismo ou vinculações com o aparato criminoso do regime, arriscou-se para salvar vidas de judeus condenados à morte.

No mesmo canteiro de obras da estrada um automóvel da SS se aproxima, e nele está Erik Dorf, que não percebe a presença de Joseph Weiss entre os trabalhadores da estrada. Kurt convida o sobrinho para tomar um café em seu alojamento e tem com ele uma conversa dura sobre os crimes cometidos em Auschwitz 
ERIK: Suas estradas são muito importantes para nós como precaução sanitária e prevenção de epidemias. Há muitas doenças em Auschwitz.

KURT: Entre os prisioneiros e entre os guardas, suponho. Doenças do espírito talvez. Ou mesmo da alma.

ERIK: Você se tornou, eu diria, mais virtuoso no insulto. Fazemos o que fazemos por necessidade.

KURT: Chega. Guarde suas mentiras para os judeus que estão matando. Mentem a eles até o último segundo. Por que têm que deixá-los nus? Pelo menos, em nome de Deus, que morram com alguma dignidade. Tenho visto soldados da SS bolinando mulheres nuas.

ERIK: São criminosos e inimigos e são enviados nus para tratamento por razões sanitárias.

KURT: Os judeus do Gueto de Varsóvia estão lutando. Pense nisso. Famintos, esfarrapados e desarmados, desafiando a raça superior. Isso quase me devolve a fé na Divina Providência.

ERIK: Disseram que você usa centenas de judeus como trabalhadores quando há russos e poloneses disponíveis.

KURT: E qual o problema?

ERIK: Não deveria. Os judeus estão destinados ao tratamento especial. Vou mandar um destacamento do Exército Vermelho, duros, fortes e idiotas.

\section{KURT: Não!}

ERIK: Por acaso você quer ajudar os inimigos do Reich? Os filhos dos trabalhadores judeus crescerão para destruir a Alemanha.

KURT: Eu devia estrangulá-lo como um favor a seu pai. Com quantos mortos ficará satisfeito? Um milhão? Dois milhões?

ERIK: Devemos eliminá-los. Do contrário será uma admissão de culpa. Temos que continuar para demonstrar ao mundo que cumpríamos uma missão. Nossa atitude é uma necessidade moral e histórica. Procure entender isso. 
KURT: Entendo muito bem. Agora, saia daqui!

A postura de Kurt Dorf em relação aos crimes cometidos pelos nazistas e clara desaprovação explicitada a Erik sobre tais crimes o posiciona entre os alemães que se opuseram aos massacres, embora esse posicionamento ocorra tardiamente. Ao lado de Inga Helms e do padre Lichtenberg ele completa a galeria de personagens alemães cujo caráter não foi desvirtuado pelo regime. Assim, além dos simpatizantes antissemitas mais ferrenhos do nazismo e dos alemães comuns que testemunharam a perseguição aos judeus mas nada fizeram, o grupo dos alemães justos entre as nações, para utilizar uma expressão da própria memorialística do Holocausto, está representado por estes três personagens.

Joseph Weiss e Franz Lowy são informados que suas esposas foram enviadas para a câmara de gás. A narrativa permite uma licença poética para inserir a comovente cena de Joseph lamentando a morte da esposa ao tocar sua bagagem com as partituras de peças musicais de Mozart e Beethoven e as fotografias da família posicionadas em uma mesa e denotando um pequeno canto familiar na brutalidade do alojamento de Auschwitz. Pouco tempo depois o próprio Joseph e Franz Lowy têm o mesmo destino. Procurando vingar-se da censura sofrida por seu tio Kurt, Erik revela a Eichmann e Höss que o engenheiro está empregando judeus na construção da rodovia. Antes que soldados da SS interrompam o trabalho para enviar os trabalhadores à morte, Franz Lowy atualiza Joseph sobre o Levante do Gueto de Varsóvia. Ao serem informados de que devem seguir para a desinfecção, os dois aceitam estoicamente o seu destino. Sem coragem para resistir à ordem, Kurt Dorf assiste à caminhada dos judeus para a morte.

O clímax deste último episódio está, de fato, no Levante do Gueto de Varsóvia, evento histórico que dá ao discurso narrativo o viés político que a minissérie procura reforçar. A reconstrução narrativa das últimas horas dos combates no gueto reforça os aspectos de proximidade e camaradagem dos resistentes. A desconfiança dos combatentes em relação ao aspecto religioso do judaísmo, frequentemente vinculado a um sinal de fraqueza e submissão por sua crença no infortúnio como castigo divino, perde espaço para uma convivência que procura, antes de mais nada, reforçar os laços de identidade. É curioso verificar, no entanto, que a minissérie modifica a data de alguns acontecimentos relacionados ao Levante do Gueto para destacar o caráter épico na representação fílmica, vinculando-o a um evento do calendário religioso. Assim, a 
madrugada de Páscoa de 19 de Abril de 1943, que historicamente marcou o início dos combates, é representada como o clímax da reação nazista ao levante que levará ao seu sufocamento. Essa mudança na representação fílmica em relação às datas históricas tem como premissa a necessidade de vincular o ato de resistência à data que simboliza o ponto máximo do ritual de memória da cultura judaica.

A vinculação da Páscoa judaica com a resistência é apresentada nas cenas que funcionam como um prelúdio dos combates mais intensos entre os resistentes e a SS. Entrincheirados em um dos vários edifícios do gueto, Moses e Zalman fazem sentinela enquanto outros combatentes descansam. Um ancião judeu do tipo ortodoxo também presente no apartamento entoa as orações do dia sagrado. A SS persiste em sua tentativa de convencer os resistentes a desistirem da luta e entregarem as armas mas o caminhão com alto-falante é recebido à bala. Reforços das tropas nazistas, formados por fileiras de policiais judeus e soldados lituanos adentram o gueto e recebem a resposta das metralhadoras disparadas por Moses, Zalman e outros combatentes. Tal resposta que resulta na fuga apressada dos soldados da SS amedrontados pelos tiros dos combatentes do gueto dá à cena o tom de revanche que os personagens judeus (e o público telespectador do teledrama, já ciente do destino das vítimas) esperam. Essa vitória provisória sobre os nazistas funciona como a catarse possível diante do inimigo brutal que inevitavelmente terminará esmagando a reação dos judeus entricheirados. Ao ver os soldados da SS batendo em retirada, Moses fica entusiasmado e exclama com exaltada satisfação: "Veja como correm. Pela primeira vez em minha vida sinto o sangue do rei Davi”.

O ritual da Páscoa, cuja encenação da ceia ocorre no mesmo apartamento em que se refugiaram os judeus combatentes, marca o início do fim desta jornada de resistência, pois a resposta nazista não tarda. O ancião compartilha com Moses e Zalman as últimas taças do vinho da celebração enquanto uma das crianças presentes, sob a luz das velas acesas na mesa da ceia, recita as quatro perguntas tradicionais. $\mathrm{O}$ ritual religioso é acompanhado pelo olhar dos combatentes em vigília preparando suas armas para o conflito eminente. Caminhões com soldados da SS fortemente armados adentram o gueto quando o rabino começa a entoar as orações:

ANCIÃO: Éramos todos escravos do faraó do Egito, e nosso eterno Deus nos tirou dali com sua mão poderosa e o braço estendido. Bendito seja Ele que tirou do 
Egito nossos antepassados. Nós, nossos filhos e os filhos de nossos filhos continuaríamos lá. Louvado seja, nosso eterno Deus, soberano do Universo. Essa noite comeremos o pão e tomaremos as ervas amargas e as especiarias que nos unem. Que possamos nos regozijar na construção de Vossa cidade e nos exultar em Vosso serviço e que possamos comer dos cordeiros pascoais sacrificados cujo sangue será salpicado nas pedras de Seu altar...
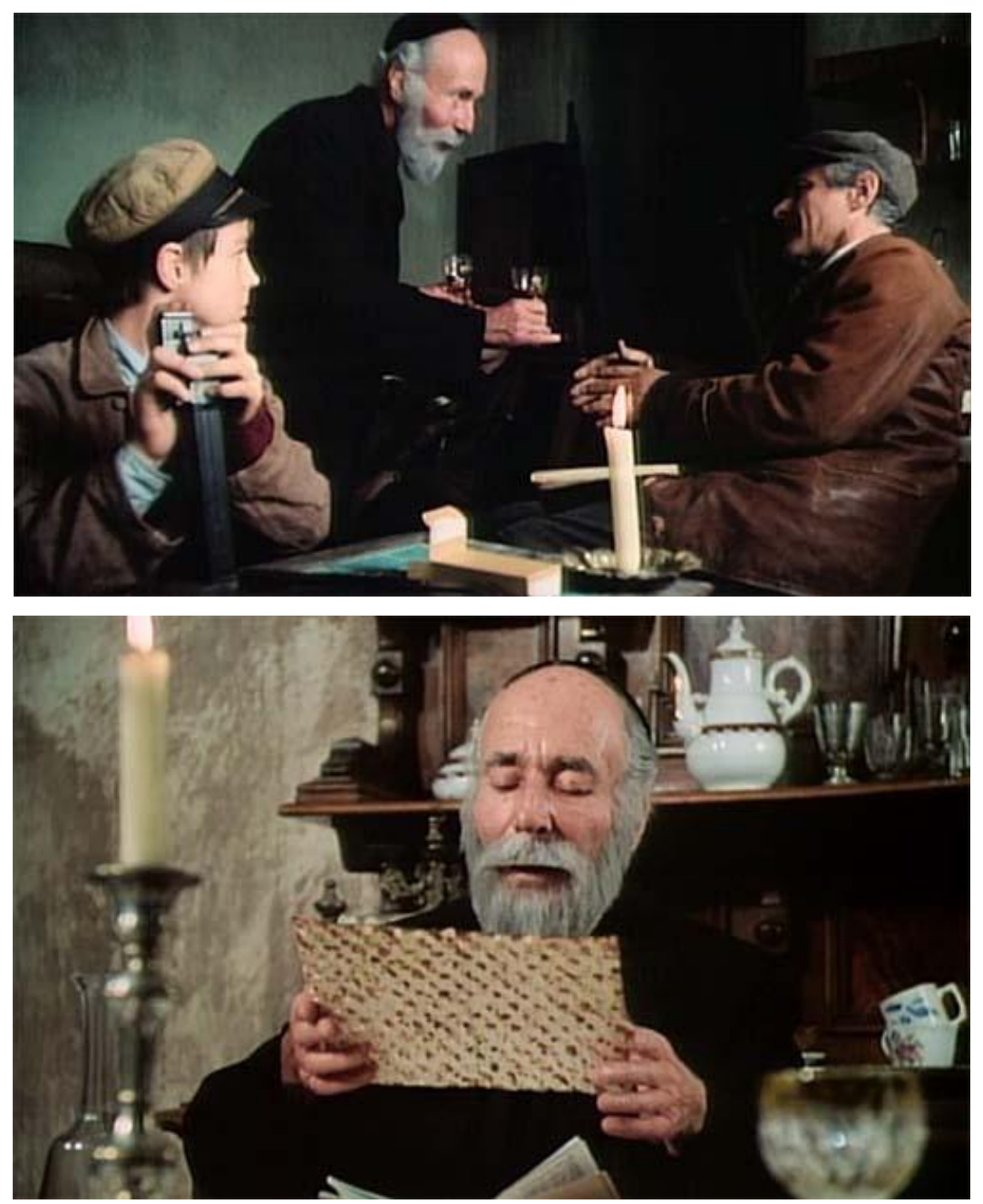

Figura 16 - Os combatentes do Levante do Gueto de Varsóvia recebem o vinho da Páscoa.

As orações do ancião prosseguem enquanto as tropas da SS tomam conta das ruas prenunciando uma repressão violenta em relação aos resistentes. O som da quebra do matzah ${ }^{102}$ pelo velho patriarca confunde-se com o forte estrondo de um tiro de canhão das tropas da SS que atinge o prédio onde os judeus estão posicionados. Os

\footnotetext{
${ }^{102}$ Pão sem fermento utilizado na celebração da Pessach, a Páscoa judaica
} 
combates mais acirrados têm início, e todos deixam o edifício em direção aos subterrâneos do gueto onde a resistência já preparou o espaço para o refúgio. Zalman, Moses, Eva e o jovem Aaron persistem na resposta à artilharia nazista com suas poucas metralhadoras, o que provoca a fuga de um grupo de soldados sob fogo cruzado. A bandeira sionista que decorava o quartel-geral dos combatentes é hasteada em uma das janelas. Diante do segundo recuo da SS, Moses mais uma vez exulta: "Demos uma boa surra nos filisteus".

É importante notar que função tem, dentro dos objetivos discursivos da narrativa do teledrama, o paralelismo entre os momentos cruciais do combate contra as tropas nazistas e a celebração do maior ritual religioso judaico. Tal paralelismo não ocorre somente no enredo do teledrama mas alcança o espectro mais externo de sua veiculação já que a estreia da minissérie também ocorre na Páscoa. Verifica-se assim a intersecção, no teledrama, de três temporalidades: a celebração da memória da fuga dos Hebreus da escravidão no Egito também é a memória contemporânea do maior infortúnio a atingir a comunidade judaica na Era Moderna, representada no ritual celebrado horas antes da destruição do gueto de Varsóvia.

A Páscoa também reforça os deveres de memória da própria identidade judaica e estabelece a aproximação da escravidão do Egito com o infortúnio nazista. A liberdade em direção à terra prometida que tal memória religiosa evoca sem dúvida nenhuma está identificada com o destino que a ideologia sionista prenuncia. O corolário de tal evocação só pode estar relacionado com as figuras míticas do judaísmo cuja marcas essenciais são a persistência e o combate. Há uma clara conexão entre o despertar do espírito combatente de Moses, reforçado também pela analogia com o Rei Davi contra o gigante filisteu Golias personificado na máquina de extermínio nazista, e um despertar comunitário maior ligado a um elemento aglutinador marcado por esse espírito de resistência. A narrativa é explicita nesta analogia na afirmação de Moses de que os filisteus foram, ao menos temporariamente, derrotados.

Com a reação nazista ao Levante, os judeus são encurralados nos subterrâneos do gueto. Mordechai Anielewicz, o líder da resistência e principal herói histórico da narrativa, percebe que este é o fim do combate. O líder dos combatentes dá permissão aos judeus dispostos a abandonar o esconderijo e entregar-se aos nazistas. Zalman afirma a Moses que permanecerá escondido. Um grupo, ainda esperançoso da 
sobrevivência, resolve sair e entregar-se e Moses se oferece para guia-los para fora dos subterrâneos. "Tenho o nome perfeito, mas temo que não poderei conduzi-los à Terra Prometida", afirma Moses com Aaron ao seu lado. Esta passagem do teledrama é a conexão mais explícita entre a jornada bíblica da fuga do Egito e o espírito heroico do Levante do Gueto de Varsóvia. Estes judeus não chegarão à Palestina, mas os que sobreviverem à perseguição e ao extermínio nazista alcançarão Israel.

Sufocados pelo gás lançado pelas tropas nazistas para força-los a sair de seu esconderijo, os remanescentes do gueto percorrem os corredores escuros entoando pela última vez a Hatikva. O hino, que já havia sido apresentado no teledrama na despedida de Berta Weiss a seus alunos, retorna agora em um reforço mais explícito de seu significado aglutinador da identidade judaica sob o sionismo. Durante todo o trajeto pelos subterrâneos do gueto de Varsóvia antes da rendição final aos algozes nazistas, os combatentes e os não-combatentes se unem naquilo que marca seu maior símbolo de resistência: o retorno a Sião. Fora dos escombros e enfileirados em frente a um paredão entre os ruinas do gueto, eles aguardam seu fuzilamento. Moses pede que todos deem as mãos e antes do sinal do comandante nazista para que as armas sejam disparadas, ele entoa as primeiras palavras da profíssão de fé do judaísmo: "Shemá Yisrael Adonai Elohêinu Adonai Echad" ${ }^{\prime 103}$. O som dos tiros da SS encerra, no enredo da minissérie, a narrativa heroica do Levante do Gueto de Varsóvia.

Com a liquidação do Gueto e a morte dos combatentes do Levante a narrativa centra sua atenção na trajetória de seu principal herói, Rudi Weiss. Recuperado do tiro que quase o matou durante a última ação, ele prepara, ao lado dos outros partisans, uma emboscada com minas terrestres para as tropas nazistas. Helena, que havia solicitado permissão para segui-lo nas ações, os acompanha. A armadilha é descoberta pelos soldados nazistas antes que seus veículos cheguem ao terreno minado, o que força os guerrilheiros a fugir apressadamente. Durante a fuga Helena é atingida pelos disparos nazistas. Ao interromper sua fuga para socorrê-la, Rudi é atingido na cabeça pelo coldre da arma de um dos soldados nazistas. Desacordado ele é feito prisioneiro e enviado ao campo de extermínio de Sobibor.

O destino de Rudi oportunamente o localiza em um outro cenário conhecido da narrativa histórica sobre o Holocausto para que ele possa fazer parte, como um de seus

${ }^{103}$ Escuta ó Israel, Adonai nosso Deus é Um 
mentores, da mais bem sucedida revolta ocorrida em um campo de extermínio nazista. Ao despertar em Sobibor, Rudi logo percebe que está preso com soldados do exército vermelho que planejam uma rebelião. Assim, a última grande ação de resistência no teledrama tem a participação do único sobrevivente judeu da família Weiss. Há uma sutil diferença em relação à representação deste episódio na minissérie e que deve ser levada em consideração. Ao se unir ao grupo que organizou a revolta do campo de Sobibor, Rudi conheceu seu líder, Barski. De fato, o líder da revolta em Sobibor e que deu os passos concretos para sua organização foi Alexander Pechersky, um tenente judeu do exército vermelho ${ }^{104}$. Pechersky ainda estava vivo durante a produção da minissérie, o que talvez justifique a decisão do roteirista em sua substituição por um personagem fictício. O importante no entanto é verificar que este personagem fictício não está claramente identificado como judeu. Rudi Weiss e os outros prisioneiros anônimos de Sobibor claramente compartilham da mesma identidade, ao contrário dos soldados do exército vermelho que colaboram na ação mas são mencionados apenas como "russos".

A rebelião de Sobibor ocorreu em fins de Setembro de 1943. Um ano e sete meses separam este acontecimento da queda do Terceiro Reich e da total rendição alemã ocorrida em 8 de Maio de 1945. Importantes acontecimentos como a deportação e o extermínio dos judeus húngaros em 1944, o avanço das tropas soviéticas na Polônia e as marchas da morte dos prisioneiros judeus para o interior da Alemanha com o recuo do exército alemão são ignorados pela narrativa do teledrama neste lapso de tempo. Apenas a morte de Karl é apresentada, durante a evacuação de Auschwitz. Ciente de que seus pais foram exterminados no local (a narrativa não esclarece de que maneira Karl chegou a tal conclusão), ele reencontra entre os prisioneiros um antigo companheiro de Buchenwald, Weinberg, que o reconhece. É ele que o informa sobre o avanço russo e que os americanos e ingleses já desembarcaram na França, prenunciando a derrota nazista. Alheio às boas notícias, Karl pede a Weinberg um lápis e um pedaço de papel. Com o som de orações judaicas ao fundo murmuradas por um dos prisioneiros, Karl faz seu último desenho antes de morrer. Seu corpo é encontrado por Weinberg algum tempo depois, quando os prisioneiros são obrigados a deixar o campo de extermínio às pressas devido à aproximação do Exército Vermelho.

${ }^{104}$ FRIEDLÄNDER, Saul. Op. Cit. P. 662. 
Com a derrota alemã, Erik Dorf encerra sua carreira como major da SS. Preso pelas forças aliadas, o ex-oficial é interrogado sobre sua participação nos crimes cometidos contra a população judaica. Seu depoimento é uma síntese simplificada da justificativa dada pela maioria dos oficiais da SS envolvidos diretamente no processo de extermínio. Ele afirma que apenas cumpria ordens de Heydrich e Kaltenbrunner. Após ser confrontado com fotos que documentam os enforcamentos e as pilhas de corpos encontradas pelas tropas aliadas nos campos de extermínio, ele aproveita um breve momento de privacidade para engolir uma cápsula de veneno que estava oculta sob a costura de sua roupa, suicidando-se.

Marta Dorf recebe uma carta não assinada informando a morte do marido com elogios aos serviços que ele prestou ao Reich. Cabe a Kurt Dorf esclarecer para a esposa do ex-oficial da SS as verdadeiras circunstâncias de sua prisão e morte.. Marta e os filhos se recusam a aceitar a verdade afirmando que Erik foi um herói. Mais uma vez Kurt Dorf representa a consciência atormentada dos alemães, agora finalmente derrotados. Ele insiste para que a família aceite o fato de que Erik foi um criminoso de guerra e sua carreira no partido nazista foi construída sobre torturas e assassinatos. Expulso pelos familiares, Kurt faz um desabafo que representa a consciência de culpa pessoal que se expande para a culpabilidade histórica, aplicada aos alemães durante os anos do nazismo: “...Eu vi, não fiz nada e acreditei na mentira. Teremos que enfrentar o que somos e o que fizemos. Não vou ficar quieto". Kurt Dorf recupera em sua fala os personagens anônimos apresentados nos episódios anteriores que testemunharam a segregação dos judeus, a Noite dos Cristais, as prisões, as deportações e finalmente o extermínio propriamente dito e que preferiram não somente agir como meros espectadores, mas também desviar os olhos para as atrocidades cometidas. A única opção possível, em suas palavras, não é o enaltecimento dos nazistas derrotados e nem o esquecimento. Ao afirmar que os alemães terão que enfrentar o que são e de que não ficará calado ele endossa o compromisso de assumir e enfrentar o passado traumático como a única maneira de prosseguir. Tal postura explica de alguma maneira o impacto que a minissérie provocou ao ser exibida na Alemanha, tema que será explorado com maior detalhe nas páginas seguintes.

A última cena de "Holocausto" é o único momento de celebração pelo fim da guerra que a narrativa destaca. Rudi Weiss termina sua jornada de guerrilheiro com a rendição alemã e chega a Theresienstadt, onde Inga o reencontra. Oportunamente ele fez 
sua passagem por Auschwitz, onde tomou conhecimento da morte de seu irmão Karl. Inga o apresenta ao filho que teve com Karl, nascido em Theresienstadt e que leva o mesmo nome do avô, Joseph. Ao abordarem o tema do destino dos milhares de judeus assassinados durante a Guerra, Inga se desculpa por ser alemã. Ela afirma que o jovem judeu tem todo o direito de odiá-la por ser ariana, mas Rudi rechaça a afirmação e diz que a mortandade de que foi testemunha o tornou imune a qualquer sentimento. Ao dizer que o cunhado tem todo o direito de odiá-la, Inga faz referência ao comportamento esperado dos judeus sobreviventes em relação aos alemães no período pós-guerra: seu ódio é justificado. Aos alemães como um todo, a partir desta perspectiva, cabe carregar a culpa e uma parcela de responsabilidade pelos crimes do Terceiro Reich.

Sem documentos, sem família e sem pátria, Rudi parte em busca de um futuro incerto. Após despedir-se de Inga, ele observa um grupo de meninos jogando futebol em Theresienstadt. São órfãos de judeus gregos de Salônica que perderam suas famílias no extermínio. Levin, um funcionário da Agência Judaica para a Palestina, o aborda e afirma já ter algumas informações sobre ele repassadas por outros prisioneiros libertados de campos de concentração. Afirmando saber de suas atuações entre os guerrilheiros judeus e de sua participação na revolta de Sobibor, Levin oferece a Rudi um trabalho:

LEVIN: Precisamos de um pastor.

RUDI: Um pastor?

LEVIN: Temos 40 crianças gregas órfãs, precisamos de alguém que as acompanhe até a Palestina. Interessado?

RUDI: Eu não falo grego nem hebraico. Acho que sou muito pouco judeu.

LEVIN: Você vai conseguir. Não é tão perigoso como ser guerrilheiro, mas não será também como uma festa de Purim. Faremos seu passaporte.

Rudi aceita a oferta e, atraído pela brincadeira das crianças, junta-se a elas no gramado. Sua dúvida pessoal a respeito de sua identidade étnica ainda persiste, a despeito da segregação e perseguição sofrida e do encontro com o judaísmo perdido em seus dias com Helena e os guerrilheiros. De fato, sua fala parece solicitar uma confirmação de tal identidade que só ocorrerá em sua emigração para a Palestina. Mais 
do que simplesmente uma identidade religiosa, é a experiência de resistência que o credencia para acompanhar as crianças órfãs em direção à futura pátria judaica. Como o "remanescente salvo" do extermínio, Rudi é o judeu da diáspora que, no retorno a Sião, revela a transformação do judeu como vítima no judeu combatente, um símbolo essencial do sionismo. A redenção deste retorno é o elemento fundamental do único final feliz possível no teledrama. 


\section{CAPITULO 3 - "Holocausto" e os limites da representação}

"Holocausto" bateu recordes de audiência nas quatro noites de exibição na TV americana. Um número aproximado de 120 milhões de espectadores acompanhou suas nove horas e meia de exibição. A minissérie alcançou a segunda maior audiência da televisão norte-americana após "Raízes". O impacto de sua exibição é evidente tanto por seu alto índice de audiência como pelo intenso debate que despertou, não só nos principais meios de comunicação (dada a sua natureza de um produto audiovisual de consumo de massa) mas também nos círculos acadêmicos e nas artes visuais, principalmente por tratar-se de uma representação televisiva para evento histórico cuja profundidade de investigação ainda não havia sido alcançada.

$\mathrm{O}$ fato é que a minissérie marcou o início de um conhecimento mais amplo sobre o Holocausto na consciência histórica do grande público, posicionando o tema para além do espaço restrito das pesquisas acadêmicas e marcando o início de sua forte presença na cultura norte-americana, além de sua transformação em um produto midiático. Ao se referir a este alcance, Simon Wiesenthal, sobrevivente do Holocausto e notoriamente conhecido por seus esforços na captura dos carrascos nazistas, afirmou que a minissérie teve o mérito de atingir mais pessoas do ele conseguiu em toda uma vida de ativismo a favor da memória do Holocausto ${ }^{105}$.

\subsection{As reações do público: perguntas e respostas}

Com base no esforço de divulgação da minissérie empreendido antes de sua exibição pelas instituições judaicas norte-americanas podemos inferir que houve uma preocupação sobre as reações do público em relação ao teledrama. Considerando esse aspecto, o Comitê Judaico Americano preparou um relatório sobre a percepção do público reunindo a opinião de grupos selecionado de telespectadores, em uma consulta feita por telefone aproximadamente três semanas após a exibição. A pesquisa procurou explorar não apenas o impacto direto da exibição de "Holocausto" mas também o

\footnotetext{
${ }^{105}$ SHANDLER, op. cit, p. 171
} 
conhecimento do público em relação ao nazismo, o comportamento dos norteamericanos para com os judeus perseguidos durante o Terceiro Reich e sua impressão a respeito dos judeus e de Israel. A amostra total da pesquisa foi de um grupo de 822 pessoas, dos quais metade viu a minissérie e a outra metade não viu.

Mesmo considerando a pequena amostragem da pesquisa, alguns resultados interessantes oferecem uma contribuição para compreender como foi o engajamento do público em relação ao teledrama. Os resultados demostraram que os que viram e os que não viram a minissérie se diferenciavam em idade, sexo e região. Entre os telespectadores do teledrama, um nível maior de renda e escolaridade era perceptível. Já entre os que não viram havia uma tendência política mais conservadora. Entre os espectadores da minissérie os judeus representavam um largo número $(5,4 \%$, comparado aos $2,7 \%$ da população judaica entre os norte-americanos) enquanto a parcela de negros espectadores (3\%) foi menor considerando o percentual de $11,5 \%$ da população negra dos Estados Unidos ${ }^{106}$.

Quando indagados sobre a impressão que a minissérie deixou, a maioria dos telespectadores, de modo geral, expressou horror em relação à crueldade nazista. A pergunta: "Você diria que assistir "Holocausto" o fez entender melhor como Hitler tratou os judeus...?", teve $60 \%$ de "sim" como resposta. Entre os que assistiram à minissérie, $83 \%$ afirmaram que a exibição de um programa como "Holocausto" na televisão foi uma boa ideia (esta porcentagem cai para $56 \%$ para os que não assistiram ao teledrama). Entre os que aprovaram a exibição, a justificativa foi de que a minissérie contribuiu para informar o público sobre os eventos representados. Já entre os que não aprovaram a exibição, 50\% afirmaram que o passado não poderia ser alterado. Uma grande parcela também justificou a desaprovação pela violência das cenas ${ }^{107}$.

Em relação ao conhecimento sobre o Holocausto nos Estados Unidos, a pesquisa procurou saber em que medida os entrevistados estavam informados a respeito do tratamento de Hitler em relação aos judeus antes de assistir "Holocausto" (para os que não viram a minissérie, a mesma pergunta foi feita sem mencionar o teledrama). Telespectadores com menos de 30 anos demonstraram saber menos sobre o evento histórico do que os mesmos entre as faixas etárias de 40 a 50 anos. Entre este grupo mais jovem, 30\% afirmaram estar pouco informados. Sobre o conhecimento dos alemães em relação ao extermínio, 44\% afirmaram que a população alemã sabia, em

\footnotetext{
${ }^{106}$ THE AMERICAN JEWISH COMMITTEE. op. cit., p. 5

${ }^{107}$ Idem, p. 6.
} 
alguma medida ou tinha alguma informação. Já $42 \%$ afirmaram que os alemães sabiam muito pouco ou desconheciam ${ }^{108}$.

Considerando a estratégia para divulgação da minissérie pela AJC e as intenções presentes no discurso de memória que sua produção procurou destacar é interessante ater-se às questões da pesquisa que buscaram elucidar a percepção do grande público na relação entre o Holocausto, os judeus e mais especificamente à comunidade judaica norte-americana. Desta forma, a primeira questão a abordar este aspecto procurou verificar qual a percepção dos telespectadores em relação às vítimas e descobrir se uma tendência significante de antissemitismo ainda existia nos Estados Unidos. O resultado da pesquisa entre os telespectadores demonstrou que no geral estes demonstravam simpatia em relação aos judeus e 55\% afirmaram que esta percepção de simpatia não foi alterada pela exibição do programa ${ }^{109}$.

Foi perguntado a todos os participantes da pesquisa se eles consideravam que a perseguição aos judeus era, em alguma instância, culpa dos próprios judeus. O resultado, de acordo com a pesquisa, foi inconclusivo já que a própria pergunta revelouse ambígua. Uma parcela dos que responderam considerou o termo "culpa" como significando a falta de percepção em relação ao que ocorria. Outros interpretaram o mesmo termo no sentido de responsabilidade moral. Um dos participantes chegou a utilizar um estereótipo antissemita ao afirmar que os judeus tinham muitos negócios e controlavam tudo e que Hitler tirou dos que tinham para dar aos que não tinham ${ }^{110}$.

Prosseguindo na investigação da percepção norte-americana a respeito da comunidade judaica, o questionário ampliou o espectro de investigação para além do teledrama e do evento histórico representado nele. Três questões exploraram este tema entre os entrevistados (entre os que viram e os que não viram a minissérie). A primeira delas afirmava: "Algumas pessoas acreditam que os judeus detêm muito poder neste país. Você concorda ou discorda?". Entre os telespectadores, $12 \%$ afirmaram concordar e $20 \%$ disseram não ter opinião formada a respeito. Entre os que não viram o teledrama, $13 \%$ concordavam e $26 \%$ declararam não ter uma opinião a respeito. Segundo as conclusões da própria pesquisa, tal resultado indicava maior indiferença e desconforto em relação aos judeus na amostragem dos que não assistiram à minissérie ${ }^{111}$.

A segunda questão procurou verificar o nível de aprovação de uma eventual

\footnotetext{
${ }^{108}$ Idem, p. 14.

${ }^{109}$ Idem, p. 16.

${ }^{110}$ Idem, p. 18.

${ }^{111}$ Idem, p. 19.
} 
perseguição aos judeus nos Estados Unidos. Em relação ao tema havia o seguinte questionamento: "você acha que a maioria, um grande número ou apenas um pequeno número de pessoas pensaria ser correto perseguir os judeus nos Estados Unidos?”. Apenas $4 \%$ afirmou achar que a maioria dos norte-americanos aprovariam tal perseguição. Entre os que achavam que poucos aprovariam, o número chegava a $52 \%$ e $30 \%$ consideravam que ninguém aprovaria ${ }^{112}$.

A terceira questão procurou explorar a percepção dos americanos em relação ao apoio majoritário da comunidade judaica norte-americana ao Estado de Israel inquirindo se tal apoio, para os entrevistados, fazia muito, algum ou pouco sentido. Quase a metade (44\%) dos entrevistados afirmou que tal apoio fazia muito sentido, e quase $30 \%$ disse acreditar que tal apoio fazia algum sentido. Em relação aos conflitos no Oriente Médio entre Israel e os países árabes, os entrevistados foram questionados se eram mais simpáticos aos árabes do que aos israelenses e vice-versa ou se consideravam-se neutros. De acordo com as conclusões da pesquisa, os resultados surpreenderam já que, por três décadas, as pesquisas apontavam um forte apoio a Israel, com pouco espaço para a neutralidade. Os resultados desta vez mostraram que $61 \%$ afirmaram neutralidade em relação ao conflito, $19 \%$ apoiavam Israel, $18 \%$ não opinaram e $2 \%$ apoiavam os países árabes. Mesmo entre os judeus, $26 \%$ afirmaram sua neutralidade em relação ao conflito.

Uma última questão explorou a percepção do público em relação ao posicionamento de Israel de não confiar na dependência de um apoio externo em sua defesa. A pergunta dizia: "Baseado no que ocorreu aos judeus na Europa durante a Segunda Guerra Mundial, judeus em Israel atualmente acreditam que eles não podem realmente depender de outros para a sua própria defesa. Você acredita que esta é uma atitude aceitável...ou eles estão equivocados...?". O próprio relatório de pesquisa afirmava que, com base na mensagem veiculada e constantemente reforçada na própria minissérie de que os judeus não receberam qualquer ajuda a não ser deles próprios, poderia haver uma maior compreensão a respeito da postura do Estado de Israel. Os resultados no entanto demonstraram que apenas 33\% dos entrevistados apontavam a postura do Estado israelense como aceitável. Para $45 \%$ a posição de Israel nesse aspecto era considerada um equívoco e $22 \%$ não opinaram. O próprio relatório especula que o posicionamento de não-concordância da maioria talvez pudesse revelar que os

\footnotetext{
${ }^{112}$ Ibidem, p. 20.
} 
israelenses não estavam demonstrando confiança necessária nos Estados Unidos como seu aliado ou que os entrevistados não gostariam de dar a entender que aprovavam a alegada intransigência ou inflexibilidade do país judeu ${ }^{113}$.

A pesquisa realizada pela AJC revelou informações relevantes sobre a reação do público a respeito da minissérie, o nível de conhecimento sobre o Nazismo e o Holocausto e a conexão deste evento com a comunidade judaica norte-americana. Tão importantes quanto seus resultados e as respostas obtidas dos entrevistados são as perguntas selecionadas pela instituição, exemplificadas acima, e que revelam uma evidente preocupação para com a percepção do público em geral sobre a comunidade judaica norte-americana, o antissemitismo e as lições históricas resultantes do genocídio nazista. Como a própria conclusão do relatório afirma:

Em geral os resultados fornecem motivos tanto para satisfação quanto para preocupação. Se por um lado confirmam que a maioria dos norte-americanos condenam o racismo e o nazismo, eles também indicam a existência de uma parcela importante de racistas e antissemitas nos Estados Unidos, além do fato de que muitos americanos, embora não sejam antissemitas, se veem a uma certa distância dos judeus e de seus problemas. ${ }^{114}$

\subsection{Televisão como banalização: memória e ultraje}

Apesar do sucesso de público e dos vários prêmios Emmy que recebeu, "Holocausto" foi alvo de críticas contundentes que se desdobraram em um debate intenso sobre temas como a mercantilização da memória da tragédia vivida pelos judeus europeus, os limites éticos da representação do genocídio nazista e a pertinência de tal representação nos meios audiovisuais. A própria natureza da produção de "Holocausto" como um produto televisivo é apontada como uma das razões para as polêmicas que o teledrama despertou durante e após a sua exibição.

Jeffrey Shandler afirma que algumas considerações positivas à minissérie destacaram sua contribuição artística ou intelectual em relação ao tema, apontando que sua principal qualidade estava no fato de ter sido efetivamente produzida e de

\footnotetext{
${ }^{113}$ Idem, p, 21.

${ }^{114}$ Idem, p. 26 (Trad. do autor). No original: "In general, the findings provide reason for both satisfaction and concern. For while they confirm that most Americans condemn racism and Nazism, they also indicate that a hard core of racists and anti-Semites remains in the United States, and that a good many Americans, without being anti-Semitic, feel themselves quite remote from Jews and their concerns."
} 
representar um marco na abordagem do assunto. Outras críticas destacam a sua eficácia dentro do que propõe enquanto discurso narrativo. Em sua análise sobre o teledrama o sociólogo alemão Dieter Prokop salienta esta questão:

A qualidade da série consiste - apesar de tudo - no fato de tratar do problema da formação de identidade. A isto também, independente de qualquer conteúdo, se deve seu sucesso público: por um lado, à "inadaptação à realidade" da grande família judia burguesa, à incapacidade de adaptar suas aspirações de felicidade à realidade e ao filho Rudi, que, contudo, enquanto tudo mais é destruído, encontra uma saída ${ }^{115}$.

Já os críticos de "Holocausto" de modo geral apontaram que a minissérie era em si mesmo problemática por tratar-se, essencialmente, de um produto televisivo ${ }^{116}$. A grande questão envolvendo tais críticas estava relacionada, fundamentalmente, com o inegável caráter comercial da produção televisiva. O crítico de televisão John O’Connor, explicitou, em um artigo para o jornal The New York Times, as questões envolvendo esta natureza problemática na sua relação com os intervalos comerciais próprios à exibição em horário nobre. Para O’Connor, o conteúdo televisivo é secundário, estabelecendo-se apenas como um meio para um objetivo monetário ${ }^{117}$. Nesse sentido, a utilização ou exploração, de acordo com o crítico, de um tema sensível como o Holocausto nazista, deve considerar algumas reservas. O crítico afirmou que os canais de televisão privados lidam com negócios, e a produção de uma minissérie como "Holocausto" acabou resultando em efeitos absurdos nas quais a diversidade do universo das propagandas televisivas compartilham, em um mesmo horário, do sofrimento e da tortura que são parte indispensável do drama apresentado:

Uma história que inclui vítimas a quem se convence que câmaras de gás são apenas um local de banho para desinfecção é interrompida por um comercial sobre o desinfetante Lysol e sua utilidade para "exterminar germes". Após várias cenas com nazistas pervertidos vendo fotografias de assassinatos em massa somos apresentados a anúncios para venda de máquinas Polaroid. ${ }^{118}$

\footnotetext{
${ }^{115}$ PROKOP, Dieter. Signos de felicidade e destruição. Holocausto: a estrutura de um produto internacionalizado de comunicação. In: MARCONDES FILHO, Ciro (Org.). Dieter Prokop. São Paulo, Ática, 1986, p. 82.

${ }^{116}$ SHANDLER, pp.cit.,p. 159.

117 O'CONNOR, John. NBC Holocaust's, Art versus Mammon. The New York Times. New York, 20 de Abril de 1978, p. 2.

${ }^{118}$ O'CONNOR, Idem, p. 2. (Trad. do autor). No original: "A story that includes victims being told that the gas chambers are only disinfecting areas is interrupted for a message about Lysol and its usefulness in 'killing germs'. After several scenes of perverted Nazi officers looking at photographs of mass murders, we are given a sales pitch for Polaroid."
} 
John O'Connor considerou que as intenções nobres da minissérie foram obliteradas por um processo de produção que buscou, no fim das contas, resultados comerciais. De maneira contundente ele chega a afirmar que, por essa razão, todo o projeto da minissérie aproxima-se da imoralidade que caracterizou o próprio evento histórico do Holocausto.

O historiador Henry Feingold foi outro crítico que destacou, entre outros pontos, o aspecto negativo do caráter comercial da minissérie. Feingold comparou as intenções da produção de "Holocausto" com a anterior e bem-sucedida exibição de "Raízes". Segundo o historiador, os executivos do canal de televisão e os produtores aplicaram a técnica da utilização de um roteiro ficcional com fundo histórico, algo que a televisão comercial descobriu como um tema a ser explorado. Esta técnica, segundo o historiador, foi então aplicada às injustiças históricas como a escravidão e o Holocausto: "Sem dúvida, temas como a saga dos índios norte-americanos, os problemas da grande fome na Irlanda ou talvez o sofrimento dos nipo-americanos internados durante a guerra já estão nos planos" ${ }^{\prime 19}$. Para Feingold, todo o projeto, começando pelo amplo esforço de divulgação da minissérie e passando por sua exibição em horário nobre, em uma sequência de quatro dias, foi preparado para obter o máximo de impacto e para que o teledrama sobre o extermínio dos judeus da Europa "fosse vendido como pasta de dente." 120

Os intervalos comerciais e as interrupções da propaganda na veiculação da minissérie estão no cerne da acusação da incompatibilidade entre o meio (o veículo televisivo e os aspectos inerentes às suas produções) e a mensagem (o conteúdo, não importando as justificativas apresentadas por seus produtores). Assim, um tema de abordagem problemática como o Holocausto, na opinião de vários críticos, explicita a incapacidade deste meio de lidar com este tema sem incorrer em uma falha ética que se revela em sua exploração comercial e banalização. A televisão é então o grande mal que envolve essa representação. Tal incompatibilidade entre o meio e a mensagem, segundo Jeffrey Shandler, resulta na perpetuação do mal que o próprio Holocausto significou: "longe de esclarecer o público a respeito deste passado trágico e ensiná-lo na prevenção

\footnotetext{
${ }^{119}$ FEINGOLD, Henry. Four Days In April: a review of NBC's dramatization of the Holocaust. Shoah: $a$ review of Holocaust Studies and Commemorations. Vol. 1, N. 1, p. 15 (Trad. do autor). No original: "Undoubtedly something about the saga if the American Indian, the Irish potato famine and the 'troubles', or perhaps the suffering of Japanese Americans interned during the war is already in the drawing boards." ${ }^{120}$ Idem, p. 15.
} 
de sua repetição no futuro, acaba por se constituir na virtual repetição e perpetuação do Holocausto". ${ }^{121}$

Outro traço comum entre as críticas ao teledrama destacou uma presumida falta de apuro estético em sua produção. Estas críticas enfatizavam vários aspectos como seu estilo kitsch, próprio de um melodrama televisivo que aproximava a minissérie de uma telenovela, a narrativa rocambolesca e pouco verossímil resultante do desafio de mostrar os personagens relacionados aos principais eventos do Holocausto e a fotografia em cores utilizada pelo teledrama. Em relação a este último aspecto, as críticas apontaram para uma necessidade de um estilo mais sóbrio porque, segundo essa acepção, o universo concentracionário deve ser representado, essencialmente em preto-e-branco ${ }^{122}$. Jeffrey Shandler faz menção aqui à utilização de fotos e filmagens dos campos de concentração e ao documentário "Noite e Neblina" de Alain Resnais. A partir disso, considera-se que o Holocausto tem uma estética própria, pouco adaptável à televisão norte-americana, que falhou ao não reproduzir tal estilo na minissérie. Dieter Prokop afirma que a representação em cores é o item problemático da minissérie, pontuando que "processos terríveis são filmados como se se tratasse de um passeio dominical que não deu certo"123. Prokop destaca as execuções em Kiev em contraste com os tons amarelos das folhagens de outono ou as cenas do campo de concentração de Buchenwald com o brilho da grama verde fresca.

As críticas apontadas até aqui compartilham, de modo geral, de uma mesma concepção do Holocausto como um evento único, para o qual é necessária uma representação específica que respeite determinados limites éticos e estéticos. A própria ideia de produzir uma minissérie em um canal de televisão privado representa uma autêntica violação e tais pressupostos. Duas críticas apresentadas a seguir aprofundam esta questão fornecendo justificativas que dão subsídio a um debate mais aprofundado sobre estes temas e a pertinência de tais críticas. A primeira delas, feita pelo escritor Elie Wiesel, ele mesmo um sobrevivente, denuncia o desrespeito a este limite ético representado pela minissérie. A segunda, presente em um artigo do cineasta e escritor Claude Lanzmann, também aborda a questão do limite ético adicionando a ele uma

\footnotetext{
${ }^{121}$ SHANDLER, op. cit., p. 173 (Trad. do autor). No original: "far from enlightening audiences about this past evil and teaching them to guard against it in the future, instead constitutes a virtual repetition or perpetuation of the Holocaust itself."

${ }_{122}$ Idem, p. 169.

${ }^{123}$ PROKOP, op. cit. p. 73.
} 
preocupação estética que se concretiza em uma espécie de apelo à não-comemoração, um traço comum aos discursos de memória de algumas produções audiovisuais sobre o tema

Um dia após a estreia de "Holocausto", Elie Wiesel publicou um artigo no jornal The New York Times, intitulado "A banalização do Holocausto" com uma crítica contundente à minissérie. Wiesel inicia seu texto afirmando que as intenções do teledrama de mostrar ao público a realidade sobre um tema que os sobreviventes tentaram há décadas testemunhar resulta em um completo equívoco: "Falso, ofensivo, barato: como uma produção para a TV, o filme é um insulto àqueles que morreram e aos que sobreviveram. Apesar do nome, este "docudrama" não é sobre o que alguns de nós nos lembramos como sendo o Holocausto"124.

Wiesel fez ressalvas em relação ao título da minissérie. Sua preocupação está no fato de que, ao dar o nome "Holocausto" para um telefilme que mescla uma narrativa fictícia com fundo histórico, os produtores do programa não se preocuparam com a utilização que os negacionistas do Holocausto poderiam fazer de tal decisão, ao não explicitarem os limites entre a ficção e a realidade. Para o escritor, a diluição entre o fictício e o real forneceria elementos para os que declaram que o Holocausto é um mito ou uma invenção, mesmo que estes sejam utilizados em uma argumentação claramente desqualificada. A opção narrativa de criar uma história fíctícia apresentando um exaustivo panorama de vários eventos da historiografia do Holocausto poderia confundir o próprio público, na opinião de Elie Wiesel, já que para os não familiarizados com tais eventos haveria uma dificuldade de discernimento entre o histórico e a narrativa de ficção. Nesta perspectiva, a credibilidade do teledrama se perde em sua proposta de narrar a história de uma família entremeada aos principais eventos da perseguição nazista aos judeus.

Autor de um dos primeiros e mais conhecidos relatos sobre a experiência nos campos de concentração e extermínio, Elie Wiesel aponta outras falhas da minissérie, sobretudo em relação à acuidade histórica e à falta de sobriedade na abordagem do assunto. Destacamos, contudo, o que ele considera sua mais grave violação: a ideia,

\footnotetext{
${ }^{124}$ WIESEL, Elie. Trivializing the Holocaust: semi-fact and semi-fiction. The New York Times. New York, 16 de abril de 1978, p 2. (Trad. do autor). No original: "Untrue, offensive, cheap: as a TV production, the film is an insult to those who perished and to those who survived. In spite of its name, this "docu-drama" is not about what some of us remember as the Holocaust."
} 
apresentada pela narrativa do teledrama, de que é possível comparar e compreender o Holocausto. As credenciais de seu próprio testemunho como sobrevivente reforçam a intensidade de tal censura:

Auschwitz não pode ser explicado e nem visualizado. Seja resultado de um processo histórico ou uma anomalia, o Holocausto transcende a História. Qualquer coisa sobre este tema inspira temor e leva ao desespero: os mortos têm a posse de um segredo que nós, os vivos, não somos dignos e nem capazes de recuperar. ${ }^{125}$

Elie Wiesel também aponta problemas estéticos, em encenações que ele considera de mau gosto, como a recriação do massacre de Babi Yar e o exagero melodramático do enredo, mas acima de tudo mantém firmemente o tom de denúncia para a violação de um terreno sagrado que a narrativa da minissérie desrespeita em seu objetivo de abarcar um longo e complexo processo de extermínio. Ao apontar a decisão dos produtores de mostrar mulheres e crianças judias em seus últimos momentos ao entrarem na câmara de gás de Auschwtiz, Wiesel reafirma o que considera indecente e desrespeitoso: "os últimos momentos das vítimas esquecidas pertencem tão somente a elas." 126

Finalizando sua avaliação crítica, o escritor e sobrevivente apresenta a sua concepção a respeito do Holocausto, justificando sua abordagem crítica, embora reconheça a dificuldade de tratar a questão desta memória e do próprio dever de cultivála:

O Holocausto? O evento máximo, o último mistério, que nunca será compreendido ou transmitido. Somente aqueles que estiveram lá sabem o que foi; outros nunca saberão. Era mais fácil para os prisioneiros de Auschwitz imaginarem-se em liberdade do que pessoas livres imaginarem-se em Auschwitz (...) O Holocausto deve ser lembrado. Mas não como um show. ${ }^{127}$

\footnotetext{
125 Idem, p 29. No original: "Auschwitz cannot be explained nor can it be visualized. Whether culmination of aberration of history, the Holocaust transcends history. Everything about it inspires fear and leads to despair: The dead are in possession of a secret that we, the living, are neither worthy of nor capable of recovering."

${ }^{126}$ Idem, p. 29. (Trad. do autor). No original: "The last moments of the forgotten victims belong to themselves."

${ }^{127}$ WIESEL, Elie, idem, p. 29. (Trad. do autor). No original: "The Holocaust? The ultimate event, the ultimate mystery, never to be comprehend or transmitted. Only those who were there know what it was; the others will never know. It was easier for Auschwitz inmates to imagine themselves free than for free persons to imagine themselves in Auschwitz (...) The Holocaust must be remembered. But not as a show."
} 
Um ano após a exibição da minissérie, o cineasta francês Claude Lanzmann publicou um artigo com o título "Do Holocausto a Holocausto", em que aprofundou as críticas feitas por Elie Wiesel, reafirmando o caráter único e a incomparabilidade do Holocausto e também denunciando o que considerou como transgressões éticas e estéticas que a minissérie norte-americana cometeu. A importância da contribuição de Claude Lanzmann para este debate está não só no fato de tratar-se de um cineasta, familiarizado com as questões que envolvem os conceitos e as complexidades da representação fílmica mas também em seu envolvimento na produção do documentário "Shoah" (1985), um filme de nove horas e meia de duração reunindo os testemunhos de sobreviventes e perpetradores do Holocausto, feito exatamente na mesma época em que a minissérie foi produzida e veiculada.

Em "Shoah" o cineasta selecionou alguns sobreviventes, ex-oficiais e burocratas nazistas, testemunhas polonesas e historiadores, colhendo alguns dos depoimentos nos exatos locais de extermínio, muitos dos quais inteiramente remodelados após trinta anos da rendição alemã. O filme de Lanzmann é totalmente construído a partir dos testemunhos e das imagens de Treblinka, Sobibor, Chelmno, Auschwitz e outras localidades em que os sobreviventes se estabeleceram após o fim da Guerra. A proposta do documentário de Lanzmann é a total recusa da representação do passado, seja através da apresentação de filmagens de arquivo ou de uma narrativa com pano de fundo histórico. O testemunho é a sua matéria-prima primordial:

\footnotetext{
"Shoah" é o monumento no qual o imperativo de viver se confunde com o imperativo de testemunhar, deixando sem efeito todo abuso da retórica. A ficção e o documentário sobre os campos, antes de depois de Shoah, veem-se até hoje impregnados pelo inventário de efeitos utilizados que os desmorona eticamente. ${ }^{128}$
}

Examinando a crítica explicitada por Lanzmann em seu artigo é possível destacar seus principais pontos de discordância em relação à minissérie "Holocausto", que terminam por aproximar-se às avaliações negativas de Elie Wiesel, já anteriormente apresentadas. A suspeita sobre a mediação televisiva é o primeiro aspecto apontado por ele ao afirmar que no esforço dos produtores de tornar possível uma identificação do público com as vítimas, estas foram caracterizadas como judeus assimilados, uma clara disposição para se aproximar do telespectador. Lanzmann questiona se o público televisivo poderia identificar-se com os judeus da Polônia, Ucrânia e Bielo-Rússia, com

\footnotetext{
${ }^{128}$ CANGI, Adrián. Imagens do Horror. Paixões Tristes. IN SELLIGMAN, Silva (org) História, Memória, Literatura: o testemunho na Era das Catástrofes. Campinas, Editora da Unicamp, 2003, p. 145.
} 
suas vestimentas típicas, suas tradições e maneirismos, sua excentricidade ${ }^{129}$. A objeção do cineasta está na busca pela "humanidade" das vítimas, que elimina sua alteridade judaica e posiciona os personagens enfrentando um dos maiores infortúnios do século XX de maneira estoica. Mas não são os ardis da ficção que incomodam Lanzmann. É a própria ideia da representação, no caso específico de uma representação ficcional, que ele crítica: “...o filme é uma obra de ficção. E, neste caso, como a realidade desafia qualquer recurso ficcional, Holocausto comete um crime moral e uma mentira; assassina a memória" ${ }^{130}$. A singularidade, e impossibilidade da representação e uma certa sacralidade já mencionada anteriormente são reforçadas nas observações do cineasta:

O Holocausto é único porque criou ao redor de si um círculo de fogo, um limite que não pode ser ultrapassado já que o absoluto horror não pode ser comunicado. Imaginar que é possível fazê-lo é cometer a mais grave das transgressões...Aqui, transgredir ou banalizar é a mesma coisa. A minissérie hollywoodiana comete uma transgressão porque banaliza, destrói a natureza singular do Holocausto, algo que o remove de qualquer comparação, que o torna o pior de todos os crimes que já foram ou serão cometidos. ${ }^{131}$

A avaliação de Claude Lanzmann revela um fato indispensável para esta análise, a saber, a recepção da minissérie pelo público internacional. Um ano após a sua estreia, "Holocausto" foi exportada para vários países do mundo, mas foi na Europa que seu debate público alcançou (e em alguns casos até ultrapassou) a intensidade verificada nos Estados Unidos, questão que será abordada a seguir.

\subsection{Televisão, memória e passado reprimido: polêmicas de uma exportação}

A exibição internacional de "Holocausto" gerou polêmicas acaloradas, sobretudo em países europeus. Na França, apesar da pouca atenção dada às alegadas inexatidões históricas da minissérie, a centralidade dos judeus como principais vítimas de Hitler foi

\footnotetext{
${ }^{129}$ LANZMANN, Claude. From the Holocaust to 'Holocaust,' Dissent Magazine, New York, vol. 1, n. 2 , 1981, p. 190.

${ }^{130}$ Idem. (Trad. do Autor). No original: "the film is a work of fiction. And in this instance, because the reality defies the resources of any fiction, Holocaust perpetrates a lie, a moral crime; it assassinates memory"

${ }^{131}$ Ibidem. No original: "The Holocaust is unique because it created a circle of flame around itself, a boundary not to be crossed since horror in the absolute degree cannot be communicated. To pretend that one has done so it to commit the graves of transgressions (...) Here, to trangress or to trivialize are alike. The Hollywood serial transgresses because it trivializes, destroying the unique nature of the Holocaust, the thing that removes it from any comparison, that makes it the worst of all crimes to have been or ever been committed."
} 
alvo de reações negativas. Alguns críticos apontaram a ausência de outros grupos perseguidos, como opositores políticos, comunistas, poloneses, russos e cristãos nãoconformistas $^{132}$. Para os franceses a polêmica também esteve vinculada à possibilidade de que a minissérie pudesse enfatizar a culpa alemã, obliterando o problemático passado do colaboracionismo francês que contribuiu para a deportação de uma parcela considerável de sua população judia durante a ocupação ${ }^{133}$. Na Áustria, terra natal de Adolf Hitler, o teledrama bateu recordes de audiência mas também gerou controvérsias. O jornal Die Presse de Viena considerou que a minissérie foi produzida apenas para gerar lucro e que os bombardeios aliados a Hamburgo ou os crimes de Stálin também deveriam ser abordados por uma série de televisão ${ }^{134}$. Em Israel, país que em 1978 abrigava mais de 400 mil sobreviventes houve certa relutância para a exibição da minissérie, mas alguns críticos apontaram que, a despeito do estilo dramático e das interrupções do horário comercial, muitos jovens revelaram que aprenderam mais sobre o evento histórico através do teledrama do que por meio de aulas de História ${ }^{135}$.

De todas as reações a "Holocausto" na esfera internacional não há dúvidas que a mais importante foi a ocorrida na antiga República Federal Alemã. A minissérie gerou um confronto inédito no país em sua problemática relação com o passado nazista e, no que diz respeito aos debates acadêmicos, com as questões da historicidade do Terceiro Reich. Antes mesmo de sua exibição, em 23 de Janeiro de 1979, a minissérie foi alvo de polêmica pela recusa de duas redes de canais de televisão de alcance nacional de adquirir os direitos de exibição com a justificativa de que a história veiculada era muito próxima a uma telenovela. Um canal de televisão regional terminou comprando a minissérie em um consórcio com outros canais, o que permitiu uma cobertura quase total para a exibição em todo o país ${ }^{136}$.

Um número estimado de 14 milhões de telespectadores (40\%) na República Federal Alemã e cerca de 3 milhões na República Democrática (pertencente ao bloco comunista) viram a minissérie. No lado ocidental uma sinagoga foi incendiada e algumas antenas de canais de televisão foram alvos de atentado por grupos

\footnotetext{
${ }^{132}$ VAST French TV audience sees start of "Holocaust". The New York Times, New York, 15 fev. 1979

133 BROWNING, Jim. French display tolerance to "Holocaust" but watch. The Christian Science Monitor. Massachusetts, 15 fev. 1979..

134 VAST French TV audience sees start of "Holocaust". Op.Cit.

135 ISRAEL DIGEST, 29 sep 1978.

136 TIME Magazine, 5 fev. 1979.
} 
neonazistas ${ }^{137}$. O teledrama foi alvo de críticas similares às sofridas em sua exibição nos Estados Unidos. Cartas e editoriais de jornais de tendência conservadora apontaram o estilo kitsch, a vulgaridade e o excesso de sentimentalismo hollywoodiano da minissérie. As críticas expressavam o desejo de esquecer o passado além de mencionarem o fato de que a Alemanha se tornara o bode expiatório para todas as atrocidades cometidas durante a Segunda Guerra Mundial. ${ }^{138}$ Novamente as questões de inexatidão histórica também foram levantadas, desta vez em relação aos uniformes e aos papéis que oficiais nazistas desempenharam ${ }^{139}$.

As críticas e reservas feitas a "Holocausto" tiveram pouco impacto se comparadas ao resultado produzido por sua exibição e ao debate público que despertou em um país que, até aquele momento, não havia de fato problematizado a questão de seu passado durante o Terceiro Reich. Os termos "catarse" e "choque" frequentemente surgiram em avaliações da imprensa nacional e internacional a respeito da reação desencadeada pela exibição do teledrama na Alemanha. Frequentemente as críticas apontadas acima eram minimizadas justificando-se a função social que o enlatado norteamericano exerceu de maneira mais ampla para o enfrentamento do passado. Segundo a revista "Times", a reação a "Holocausto" foi similar ao que ocorreu nos Estados Unidos com "Raízes" no que se refere a uma ampla discussão social de uma ferida histórica traumática ${ }^{140}$. A diferença neste caso é que essa reação foi despertada por um produto cultural estrangeiro, produzido com intenções distintas à função que, ao fim, terminaria por exercer.

De acordo com Judith Doneson, novamente um produto da cultura popular norte-americana tornou-se o árbitro da moralidade forçando países europeus a confrontarem seu passado na Segunda Guerra Mundial, frequentemente reprimido ${ }^{141}$. Uma avaliação do semanário Der Spiegel sumariza o poder da exibição de "Holocausto" na Alemanha:

Uma minissérie norte-americana banal fez o que centenas de livros, peças de teatro, filmes, programas de TV, milhares de documentos e todos os julgamentos sobre os campos de concentração e mais de três décadas de história do pós-guerra nunca conseguiram fazer: apresentar aos alemães uma

\footnotetext{
${ }^{137}$ Idem, p. 115.

138 JEWISH FRONTIER, Abril de 1979, p. 14

139 THE GERMAN TRIBUNE, 4 de Fevereiro de 1979, número 875, p. 4.

${ }^{140}$ TIME Magazine, Op. Cit, p. 115.

${ }^{141}$ DONESON, Judith. Op. Cit. p. 192.
} 
imagem tão forte dos crimes contra os judeus cometidos em seu nome que fizeram milhões ficarem chocados. ${ }^{142}$

A revista considerou que as reações à minissérie marcaram uma "semana histórica". De acordo com a publicação, até o momento de exibição do teledrama a utilização do termo Holocausto para designar a perseguição e o extermínio dos judeus durante o Terceiro Reich era uma palavra exótica para a sociedade alemã. A série entronizou a palavra nas discussões despertadas por sua transmissão, não só entre o público mas também nos debates do parlamento. A revista faz menção a reuniões de sindicatos que foram encurtadas para que os trabalhadores associados pudessem acompanhar a exibição, e seminários de sociologia em algumas universidades foram convertidos em discussões sobre o tema ${ }^{143}$.

O chanceler Helmut Schmidt, primeiro-ministro alemão na época em que a minissérie foi exibida, afirmou que o teledrama teve o poder de encorajar uma reflexão crítica em relação ao fim do prazo para a mudança da lei relativa à limitação de condenações para crimes de guerra cometidos durante o Terceiro Reich. A expiração do limite estava prevista para o final do ano de 1979. O parlamento alemão terminou por decidir pela abolição do estatuto que limitava as condenações. Tal decisão foi creditada por alguns como resultado das reações produzidas pela minissérie ${ }^{144}$. Sete meses após a exibição da minissérie, as comemorações pelos 40 anos do início da Segunda Guerra Mundial revelaram um novo ambiente de análise e de interesse pelo passado nazista no país. Sociólogos apontaram que a minissérie contribuiu para a atenção dada ao tema, e o próprio chanceler alemão afirmou, em um discurso, a importância da minissérie para informar a nova geração de alemães por meio de uma narrativa que utilizava a emoção em detrimento da frieza das investigações acadêmicas ${ }^{145}$.

Thomas Elsaesser aponta que as reações do público alemão eram complexas. Uma espécie de ambiente de abertura para um passado reprimido resultou tanto em demonstrações quase histéricas e exibicionistas de culpa, vergonha e remorso como também condenação e algum sentimento de ofensa em relação ao produto cultural

\footnotetext{
${ }^{142}$ DER SPIEGEL apud DONESON, Judith. Op. Cit. p. 192 (Trad. do autor). No original: “An American TV series of a trivial sort has done what hundreds of books, plays, films and TV broadcasts, thousands of documents, and all the concentration camp trials in more than three decades of post-war history never succeeded in doing: It presents to the Germans so strong an image of the crimes against the Jews performed in their name, that millions were shocked."

${ }^{143}$ DER SPIEGEL, 29 Jan 1979, p. 18.

${ }^{144}$ NOVICK, Peter. Op. Cit. p. 213.

${ }^{145}$ THE NEW YORK TIMES, 2 Set. 1979, p. 9.
} 
estrangeiro. Alguns cineastas estiveram entre os que reforçaram a condenação, repetindo as críticas já anteriormente apresentadas de banalização, excesso de sentimentalismo e a questão dos limites éticos da representação do evento traumático. Algumas produções diretamente vinculadas ao chamado Novo Cinema Alemão foram produzidas a partir de um interesse renovado sobre o passado traumático sob o nazismo e a identidade nacional ou de uma resposta audiovisual despertadas, em parte, pela exibição de "Holocausto"," A minissérie "Heimat", dirigida por Edgar Reitz e cuja produção foi iniciada logo após a exibição de "Holocausto", foi uma espécie de resposta alemã a uma alegada interferência exterior nos temas da memória social do país. Reitz afirmou que a Alemanha foi obrigada a renunciar ao prazer narrativo de recuperar a memória de seu passado ao se sentir aterrorizada moralmente por espetáculos audiovisuais como "Holocausto":

\begin{abstract}
Autores do mundo inteiro estão tentando tomar posse de sua própria história, e consequentemente, da história do grupo a qual pertencem. Mas frequentemente eles descobrem que sua própria história é arrancada de suas mãos. $\mathrm{O}$ ato mais sério de expropriação ocorre quando alguém é privado de sua própria história. Com "Holocausto", os americanos roubaram a nossa história ${ }^{147}$.
\end{abstract}

As alegações de Edgar Reitz acima mencionadas e as reações a "Holocausto", tanto nos Estados Unidos quanto internacionalmente, evidenciam uma problematização indispensável sobre três aspectos que balizam as hipóteses desta investigação. Tais aspectos envolvem as relações complexas entre a História, os discursos de memória e as intenções destes discursos, neste caso específico vinculadas diretamente ao desejo de coesão comunitária de determinado grupo. A recepção de tais discursos de memória, em alguns casos, pode gerar resultados completamente inesperados quando transplantados para outros ambientes e situações, algo que exemplificamos claramente acima no que diz respeito à exibição de "Holocausto" na Alemanha.

\footnotetext{
${ }^{146}$ ELSAESSER, Thomas. Subject positions, speaking positions: from Holocaust, Our Hitler and Heimat to Shoah and Schindler's List in SOBCHACK, Vivian (Org.) The Persistence of History: cinema, television and the modern event. New York : Routledge, 1996. p. 159.

${ }^{147}$ SANTNER, Eric L. History beyond the pleasure principle: some thoughts on the representation of trauma in FRIEDLÄNDER, Saul (Org.) Probing the limits of representation: Auschwitz and the Final Solution, Harvard: Harvard University Press, 1992, p. 150. (Trad. do autor). No original: "Authors all over the world are trying to take possession of their own history and therewith of the history of the group to which they belong. But they often find that their own history is torn out of their hands. The most serious act of expropriation occurs when a person is deprived of his or her own history. With Holocaust, the Americans have taken away our history."
} 
Nesta etapa é possível estabelecer algumas hipóteses que respondam às inquietações que originaram esta investigação. "Holocausto" apresenta uma narrativa ficcional com fundo histórico, destacando um discurso de memória que procura reforçar laços de identidade étnica através do passado traumático. Existe alguma contribuição possível, no caso específico desse discurso de memória, para o conhecimento histórico propriamente dito? Se tal contribuição tem pertinência, qual é a sua natureza? É possível que este discurso de memória, em parte ficcional, possa oferecer ao conhecimento histórico novos insights em relação às alegadas amarras da busca pela objetividade da disciplina histórica? O capítulo a seguir tentará elucidar algumas dessas questões. 


\section{CAPÍTULO 4 - "Holocausto" entre a História, a memória e a comemoração}

Procurou-se demonstrar até aqui, a partir da análise da minissérie "Holocausto", a importância desse documento como um discurso audiovisual que procurou destacar um evento histórico traumático como componente afirmativo da identidade judaica. Sob o ponto de vista da análise historiográfica, a minissérie é um produto audiovisual com uma clara proposta de recuperar determinado discurso de memória a respeito do genocídio da população judaica europeia em conformidade com anseios e preocupações de sua época de produção. Para uma reflexão sobre tais intenções e seus resultados é fundamental recuperar a trajetória desta mesma memória nos Estados Unidos e as razões de sua emergência na cena pública no período histórico analisado.

É consenso entre os historiadores que a memória sobre a perseguição e extermínio dos judeus europeus e as atrocidades sofridas pelos judeus sobreviventes que emigraram para os Estados Unidos foi negligenciada durante as primeiras décadas do pós-guerra. Alguns anos mais tarde a centralidade desta memória na cultura norteamericana tornou-se tão evidente que terminou por cunhar o termo "americanização do Holocausto". Como já foi apontado, a produção de "Holocausto" ocorre em um momento crucial de valorização dessa memória. A reflexão proposta nesta investigação considera os elementos que possibilitaram não só a negligência dessa memória como também as causas de sua emergência nas décadas de sessenta e setenta.

As primeiras notícias sobre as atrocidades cometidas contra os judeus da Europa durante a Segunda Guerra Mundial chegaram aos Estados Unidos principalmente por meio da imprensa judaica. Estes relatórios passaram a ser mais frequentes a partir da invasão da União Soviética pelo exército alemão em 1941 e informavam os seguidos massacres cometidos pelos Einsatzgruppen no território recém-conquistado. Nas raras vezes em que a menção a estes massacres chegava às páginas dos principais jornais do país, a identidade judaica das vítimas era ocultada sob a classificação geral de crimes nazistas contra a população civil.

Parte do ceticismo da imprensa e de uma parcela da população a respeito da Solução Final era resultado da própria escala de barbaridade dos crimes cometidos. Para 
muitos era difícil acreditar que uma nação tida como civilizada como a Alemanha houvesse mergulhado em tamanho barbarismo. David S. Wyman destaca que as informações sobre o extermínio não circulavam nas publicações de maior alcance público e eram raramente mencionadas no rádio (um veículo de grande alcance de massa) o que contribuiu para o pouco apelo para uma ação de defesa das vítimas ${ }^{148}$. Por último e não menos importante deve-se mencionar o antissemitismo presente na própria sociedade norte-americana da época como uma barreira para a criação de uma identificação com o destino dos perseguidos.

Nos primeiros meses de 1945, com o avanço das tropas aliadas na Europa Ocidental, os exércitos britânico e americano testemunharam visualmente o grau de atrocidade do regime nazista. Os campos de concentração de Bergen-Belsen, Buchenwald, Dachau e alguns outros se tornaram mundialmente conhecidos nas fotografias reproduzidas nos jornais e registros cinematográficos exibidos nas salas de cinema. Uma das primeiras decisões tomadas pelas tropas aliadas ao se depararem com os campos de concentração foi documentar o estado miserável das vítimas e as quase inacreditáveis pilhas de cadáveres dos que morreram antes da libertação ${ }^{149}$.

$\mathrm{O}$ aspecto perturbador dessas imagens, apresentando um cenário de horror sem precedentes, marcou a simbologia do final da guerra ${ }^{150}$. Diferentes dos campos de extermínio da Polônia encontrados pelo exército vermelho, os campos de concentração na Alemanha e na Áustria apenas em parte revelavam a política de aniquilação da população judaica que fundamentava a ideologia nazista. Eram de fato um registro parcial do processo de extermínio.

O testemunho virtual dos crimes nazistas na Europa, sobretudo na exibição das imagens cinematográficas da libertação dos campos em cinejornais, configurou-se como uma experiência moral para o grande público. No caso específico dos Estados Unidos, o espanto com a amplitude dos crimes tinha direta relação com a omissão e a descrença anterior em relação aos primeiros informes sobre o extermínio que chegaram ao país. Relatos sobre os massacres perpetrados pelas SS no Leste Europeu e na União Soviética foram com frequência rechaçados como mera propaganda ou tiveram uma cobertura insignificante por parte da imprensa.

\footnotetext{
${ }^{148}$ WYTMAN, op. cit., p. 29.

${ }^{149}$ CITRINOWICZ, Roney. op. cit. p. 154.

${ }^{150}$ BRINK, Cornelia. Secular icons: looking at the photographs from nazi concentration camps. History \& Memory. Indiana: Indiana University Press, vol. 12, n. 1, 2000, p. 136.
} 
Em que pese o impacto da verdade sobre os crimes do nazismo na sociedade americana, o discurso geral que acompanhava as imagens dos campos de concentração recém-libertados quase nunca mencionava o caráter específico deste crime em relação às vítimas judias. Peter Novick demonstra que tanto na narração do filme gravado em Buchenwald quanto nas palavras do general Dwight Eisenhower sobre os campos de concentração não há menção a judeus a não ser como parte do rol das vítimas da violência nazista. De maneira geral, os relatos de jornais fazem menção a prisioneiros políticos, trabalhadores escravizados e civis das mais diversas nacionalidades ${ }^{151}$. Relatando sua visita a Buchenwald logo após a libertação do campo, o repórter da CBS Edward R. Murrow descreve com detalhes as péssimas condições do lugar, mas não faz menção a nenhum sobrevivente judeu, apesar de relatar algumas das nacionalidades de alguns prisioneiros com quem fez contato. ${ }^{152}$

De fato, a aniquilação da população judaica deu-se majoritariamente em Auschwitz, Treblinka, Majdanek, Sobibor e outros campos de extermínio da Polônia (além dos massacres cometidos pelos Einsatzgruppen na União Soviética ocupada). Um número considerável de judeus que escaparam desse destino perdeu suas vidas nas longas marchas da morte em direção à Alemanha, com o avanço das tropas soviéticas, o que explica a sua não predominância entre os libertados. Com a quase inexistência de registros visuais sobre os campos de extermínio acima mencionados (com exceção de Auschwitz), as imagens que ilustrariam o Holocausto para a posteridade quase sempre são dos campos de concentração encontrados pelas tropas americanas e britânicas.

A partir do exposto acima, pode-se afirmar que o impacto dos crimes do regime nazista na sociedade americana do imediato pós-guerra, embora não ignorasse o papel preponderante do antissemitismo nazista e a perseguição aos judeus pelo regime de Hitler, esteve acompanhado de um discurso universalista no que diz respeito às vítimas. Nesse sentido os judeus apenas completavam o quadro dos perseguidos pelo Terceiro Reich. O fim da guerra na Europa e a continuidade da guerra no Pacífico, que culminou com as tragédias atômicas de Hiroshima e Nagasaki, diminuiu de certa forma o impacto da verdade dos crimes do nazismo no público americano. O discurso universalista sobre os mesmos crimes acompanharia as representações posteriores sobre o Holocausto na

\footnotetext{
${ }^{151}$ NOVICK, op. cit., p. 64

${ }^{152}$ Disponível em http://www.lib.berkeley.edu/MRC/murrowbuchenwaldtranscript.html . Acesso em 15.04. 2014
} 
década seguinte, marcada sobretudo pela reticência da própria comunidade judaica americana em dar destaque ao maior período traumático de sua história.

Esta reticência em relação à memória do Holocausto por parte da comunidade judaica pode ser observada ao se analisar o tema dos relatos testemunhais dos sobreviventes judeus que emigraram para os Estados Unidos. Nos anos imediatamente posteriores à guerra a maioria desses sobreviventes, apesar de estar disposta a falar sobre o passado, não encontrou um ambiente receptivo para relatar suas experiências traumáticas sob o nazismo. Henry Greenspan nos oferece um exemplo ao relatar o estigma sofrido por Manny Petcheck, um sobrevivente de Auschwitz que revela a interdição sofrida ao desejar contar suas experiências aos parentes e amigos próximos: "Eu pessoalmente teria me sentido muito melhor se pudesse ter falado sobre isso. Mas eu não sentia que podia fazê-lo. Ninguém se importava. Quero dizer, todos diziam que não queriam me ouvir" ${ }^{153}$.

Diversos autores se debruçaram sobre a questão da repressão à memória das experiências dos sobreviventes do Holocausto e suas causas. Alguns estudos apontam que a conjuntura histórica desempenhou um papel preponderante na opção pelo silêncio. O contexto doméstico e a política externa dos Estados Unidos ajudam a compreender as opções e as escolhas da comunidade judaica no período. Com o fim da Segunda Guerra Mundial o país tornou-se a nação mais poderosa do planeta. As tensões surgidas entre os aliados a partir da divisão dos poderes políticos e econômicos na Alemanha resultaram na Guerra Fria, e o mundo dividiu-se nas áreas de influência dos Estados Unidos e da União Soviética.

Peter Novick faz menção a questões geopolíticas que explicam o constrangimento de se mencionar o Holocausto na arena pública a partir da reabilitação da Alemanha como o novo parceiro americano na Europa. Segundo o historiador, os comunistas soviéticos substituíram os nazistas como o novo mal a ser eliminado pelo mundo ocidental democrático liderado pelos Estados Unidos ${ }^{154}$. A divisão da Alemanha transformou a República Federativa Alemã em aliada incondicional dos americanos na luta contra o comunismo. Novick afirma que o surgimento do conceito de

\footnotetext{
${ }^{153}$ GREENSPAN, Henry. Imagining Survivors: testimony and the rise of Holocaust consciousness In: FLANZBAUM, Hilene (Org). The Americanization of the Holocaust. Baltimore: John Hopkins, 1999, p.51. (Trad. do autor). No original: "I personally would have felt much better if I could have talked about it. I didn't feel that I couldn't. Nobody cared. I mean, people, everybody was talking they didn't want to hear about it. They didn't want to listen."

${ }^{154}$ NOVICK, op. cit., p. 86
} 
"totalitarismo" para designar os regimes nazistas e comunistas minimizou em alguma medida a responsabilidade alemã em relação aos crimes do Terceiro Reich. A explicação conceitual de que em um regime totalitário a oposição é quase impossível possibilitou em parte uma absolvição em relação ao passado recente alemão ${ }^{155}$.

Como era de se esperar, a reabilitação da Alemanha na aliança com os Estados Unidos não foi bem vista por uma parcela da comunidade judaica do país. Esta oposição, no entanto, esbarrou em um dilema interno da própria comunidade. Tal como outros grupos de imigrantes dos Estados Unidos, os judeus lutavam há anos para serem assimilados à sociedade americana. O sentimento antigermânico no contexto político da Guerra Fria poderia gerar uma mensagem equivocada em relação a esse americanismo justamente em um momento em que a fidelidade à nação era um valor acima de qualquer outro.

Em relação à política interna do pós-guerra, o maior exemplo foi a histeria anticomunista do macartismo. O maior temor dos líderes da comunidade judaica era a associação entre os judeus e o comunismo, já utilizada anteriormente pelo regime nazista para angariar a simpatia a sua política antissemita explorando o imaginário popular que associava os judeus ao bolchevismo. Logo depois da Primeira Guerra Mundial e da Revolução Russa, vários comunistas judeus haviam sido deportados dos Estados Unidos acusados de agitação política. A condenação e posterior execução do casal Rosenberg em 1953 fez aumentar os temores dessa associação. Filhos de imigrantes judeus, Julius e Ethel Rosenberg foram acusados de espionagem ao passarem informações sobre a bomba atômica para a União Soviética. O episódio Rosenberg aumentou o esforço das associações judaicas para combater a equação judeucomunista $^{156}$. A tendência de diminuição do antissemitismo no período, no entanto, impediu que essa associação se sedimentasse ${ }^{157}$.

De acordo com Hilene Flanzbaum, a partir do conhecimento sobre o genocídio europeu, os judeus americanos perderam parte de seu status alienígena. Os problemas da comunidade judaica neste período do pós-guerra definiam-se mais por termos institucionais do que étnicos. Os princípios de uma identidade nacional monolítica também ocupavam um lugar de importância no período. Valorizar o Holocausto teria o significado de um retorno a um passado europeu que muitos, no desejo de obter uma

\footnotetext{
${ }^{155}$ NOVICK, op. cit., p. 87.

${ }^{156}$ Idem, p. 93.

${ }^{157}$ DONESON, op. cit., p. 64.
} 
identidade americana, queriam esquecer ${ }^{158}$. Por mais profunda que a experiência do Holocausto fosse para os sobreviventes ou para a identidade judaica no período, a integração social da comunidade no ideal da nação americana parecia estar em um patamar superior de importância.

De fato, o pós-guerra abriu novas oportunidades para boa parcela da comunidade judaica no país. Segundo Alan Mintz, barreiras discriminatórias contra judeus em universidades de prestígio foram abolidas no período e o acesso a profissões liberais foi facilitado. Com uma visível ascensão social, muitos judeus procuraram dissolver sua distinção étnica na esfera pública ${ }^{159}$. Esquecer o Holocausto fazia parte deste esforço. Para este autor, há uma concepção equivocada a respeito da pouca atenção dada ao Holocausto por parte dos judeus americanos no imediato pós-guerra que a justifica como resultado dos efeitos do trauma. Tal concepção é falha ao não considerar que isso só é aplicável à parcela dos sobreviventes e refugiados ou dos que perderam seus parentes mais próximos durante a guerra ${ }^{160}$. Para a maioria da população judaica americana, o horror do Holocausto e seu aspecto traumático ainda não estavam tão próximos como viriam a se tornar posteriormente.

Como já foi mencionado anteriormente, na década de 60 a luta pelos direitos civis inseriu um novo elemento social que possibilitou a valorização das identidades étnicas nos Estados Unidos. A desvalorização desse ethos integracionista e sua substituição pelos particularismos comunitários teve alguma influência na opção das elites judaicas norte-americanas de destacar as características que diferenciavam esta comunidade em relação aos outros grupos. Analisando os meandros dessa valorização étnica, Matthew Frye Jacobson nos dá um panorama do contexto social em que ele ocorreu:

O exemplo do nacionalismo negro e do surgimento do multiculturalismo forneceu uma nova linguagem que já não remetia simplesmente ao "americano". Após décadas de esforço para se adequar ao padrão anglo-saxão, descendentes de imigrantes europeus abandonaram o "melting pot". ${ }^{161}$

Jacobson afirma que ocorreu a emergência de uma nova sintaxe de

\footnotetext{
${ }^{158}$ FLANZBAUM, op. cit., p. 20

${ }^{159}$ MINTZ, op. cit., p. 6

${ }^{160}$ Idem, p. 7

${ }^{161}$ JACOBSON, op. cit., p. 2. (Trad. do autor). No original: "The example of Black Nationalism and the emergence of multiculturalismo had provided a new language for an identity that was not simply 'American'. After decades of striving to conform to the Anglo-Saxon standard, descendants of ealier European immigrants quit the melting pot."
} 
nacionalidade e pertencimento. Segundo ele, a força política mais poderosa dessa valorização foi o movimento pelos direitos civis da população negra. O destaque nacional dado para a debate sobre a injustiça contra os negros e suas demandas por igualdade constitucional fez com que rapidamente outros grupos étnicos não-negros procurassem se dissociar da arena de privilégio dos brancos. Tal postura tinha como objetivo demonstrar que, filhos de imigrantes, eles não faziam parte da elite repressora que exterminou os índios ou escravizou os negros ${ }^{162}$.

Eric J. Sundquist afirma que a revolução dos direitos civis não era a razão primordial da valorização do orgulho étnico pelos judeus americanos, mas funcionou como um disparador em direção a essa escolha. Segundo este autor, o ocultamento ou o caráter ostensivo da etnicidade sempre foi uma opção para o judeu, o que marcou a diferença com o afro-americano, cujo elemento primordial de identidade era a cor da pele $^{163}$. O privilégio da cor branca que facilitou a assimilação da comunidade judaica nos Estados Unidos levou algumas lideranças do movimento negro a se utilizar de explicações de caráter antissemitas para essa assimilação, muitas vezes baseadas na justificativa financeira $^{164}$. A conjuntura da valorização das especificidades étnicas nos Estados Unidos também marcou uma cisão entre os judeus e os afro-americanos.

Foi no contexto dessa valorização étnica que houve uma mudança sensível na percepção dos judeus americanos em relação ao Holocausto. Neste momento, a memória sobre a Solução Final começou a sair lentamente da marginalidade e aos poucos ocupou um lugar de destaque no processo de reafirmação étnica evidenciado no período. Para muitos estudiosos do tema, a captura e o posterior julgamento de Adolf Eichmann em Israel desempenharam um papel preponderante nesse processo. $\mathrm{O}$ julgamento de Adolf Eichmann representou o fim da percepção universalista do Holocausto, distinguindo o genocídio judeu da generalidade da barbárie nazista. Tal distinção possibilitou que, pela primeira vez, o público americano passasse a ver o Holocausto como uma tragédia específica do povo judeu. De acordo com Jeffrey Shandler, o julgamento também gerou um interesse sem precedentes sobre as experiências do povo judeu durante o nazismo. Um volume considerável de estudos científicos, filmes e obras literárias a respeito do evento surgiu no mesmo período,

\footnotetext{
${ }^{162}$ Idem, p. 21.

${ }^{163}$ SUNDQUIST, Eric J. Strangers in the land: Blacks, Jews, post-Holocaust America. Cambridge: Harvard Universty Press, 2005, p. 65.

${ }^{164}$ Idem, p. 66.
} 
marcando as primeiras produções sobre a memória do Holocausto para o grande público $^{165}$. O primeiro grande estudo acadêmico de um historiador sobre o genocídio judeu, o livro "The Destruction of the European Jews", do historiador Raul Hilberg, foi publicado em 1961. No ano anterior Elie Wiesel havia publicado "Noite", clássico relato de suas experiências em campos de concentração e extermínio.

Embora impactante em alguma instância, o julgamento de Eichmann não fez perdurar um interesse visível a respeito do Holocausto pela comunidade judaica. Débora Lipstadt afirma que a resposta do interesse público em relação ao julgamento e a outros eventos mencionados acima não serviu para abrir um caminho de valorização de sua memória na comunidade judaica. Tais eventos, assim como a publicação de livros e produção de filmes sobre o tema foram responsáveis, pelo menos em parte, por abrir o caminho para um interesse em maior escala a respeito do Holocausto que ocorreria já nos últimos anos da década de sessenta ${ }^{166}$.

De acordo com a mesma autora, era necessária uma mudança na própria natureza da sociedade americana que pudesse aliar a valorização étnica do final dos anos 60 e início da década de 70 ao desejo de valorizar a memória do Holocausto por parte desta comunidade. Do ponto de vista mais geral, os protestos contra a Guerra do Vietnã tiveram alguma influência nessa decisão, segundo esta Lipstadt. Do ponto de vista mais específico da identidade judaica, a Guerra dos Seis Dias, em 1967, fez emergir o temor de uma nova ameaça ao povo judeu que contribuiu para a recuperação da catástrofe da Solução Final. A combinação da Guerra dos Seis Dias com a experiência dos Estados Unidos no Vietnã contribuiu para o interesse dos americanos no Holocausto não somente como um evento que atingiu os judeus da Europa, mas como algo em que o país participou como libertador. A Guerra dos Seis Dias reviveu a pauta da eterna vulnerabilidade dos judeus, desta vez contra um novo inimigo representado pelos países árabes. A vitória arrasadora de Israel no conflito resultou não apenas no crescimento do orgulho dos judeus do mundo inteiro como também modificou para sempre o status do Israel e dos próprios judeus americanos de modo mais amplo ${ }^{167}$.

\footnotetext{
${ }^{165}$ SHANDLER, op. cit., p. 84.

${ }^{166}$ LIPSDADT Debora E. America and the Memory of the Holocaust. 1950-1965. Modern Judaism, Oxford University Press, vol. 16, n. 3, p. 204.

${ }^{167}$ MAGID, Shaul. The Holocaust and jewish identity in America: memory, the unique, and the universal," Jewish Social Studies: History, Culture, Society, Indiana University Press, vol. 18, n. 2,2012
} 
Jacob Neusner aprofunda o significado da Guerra dos Seis Dias no imaginário judaico e seu simbolismo como componente de afirmação étnica tanto para os judeus do Estado de Israel quanto para os judeus norte-americanos. De acordo com Neusner, o corolário do Holocausto está diretamente vinculado à redenção para os judeus de Israel. Segundo este autor, a vitória do país na guerra e o retorno dos judeus ao antigo muro do Templo de Jerusalém, em 10 de Junho de 1967, marca a transformação do extermínio dos judeus europeus no que se tornou mais tarde "o Holocausto". A diferença é que a relação entre Holocausto e redenção para o contexto dos judeus norte-americanos é mais problemática, já que os Estados Unidos se fecharam aos judeus perseguidos pelo nazismo e o país não representou um lugar de esperança e refúgio. A redenção, para esse autor, não oferece uma resposta satisfatória para a recuperação da memória do genocídio. Tal resposta está na própria incerteza de um caráter distintivo:

Muitos judeus norte-americanos, embora continuem a afirmar seu judaísmo,
não têm uma noção muito clara do que é ser judeu ou o que esta herança
judaica exige deles. O judaísmo é, para esta parcela crítica da população
judaica norte-americana, meramente um ponto de referência, um fato entre
outros. (...) E "o Holocausto" fornece esta resposta: "Hitler sabia que você é
judeu" 168.

Em "Holocausto" o percurso da família Weiss em direção ao encontro de sua herança étnica judaica é feito exatamente a partir do momento que a perseguição nazista os atinge. O cosmopolitismo do judeu assimilado dá lugar uma solidariedade comunitária no infortúnio como componente fundamental de resistência ao inimigo nazista. Esta trajetória está claramente explícita no enredo.

As explicações listadas acima claramente se referem a escolhas tácitas resultantes de decisões circunstanciais, frequentemente vinculadas a um claro posicionamento político e ideológico de tal representação. Há no entanto uma série de autores que apontam a emergência de tal memória como um percurso natural ligado ao aspecto traumático do Holocausto. Neste sentido, a recuperação de tal memória significaria o retorno do reprimido, no sentido freudiano do termo. A teoria de Freud sobre o recalque resultante de um evento traumático explicaria, dentro desta

\footnotetext{
${ }^{168}$ NEUSNER, op. cit, p. 89. (Trad. do autor). No original: "many American Jews, though they continue to affirm their Jewishness, have no clear notion of how they are Jewish, or what their Jewish heritage demands of them. Judaism is, for this critical part of the American Jewish population, merely a reference point, one fact among others (....). And 'the Holocaust' provides that answer: 'Hitler knew you were Jewish'."
} 
perspectiva, o abafamento dessa memória nos primeiros anos do pós-guerra. Aqui valoriza-se essencialmente a figura das testemunhas que passam a relatar suas experiências, publicando relatos e apresentando-se em eventos públicos de rememoração, décadas depois dos eventos relatos.

Jeffrey Shandler relaciona a valorização do testemunho dos sobreviventes com a necessidade de registrar seus relatos devido ao seu envelhecimento e inevitável desaparecimento com o passar dos anos. Neste sentido, a necessidade de contar as experiências traumáticas estaria vinculada ao processo de revisão da própria história de vida $^{169}$. Este autor também estabelece uma relação entre o envelhecimento desta geração de sobreviventes do Holocausto (e consequentemente dessa mesma memória) e o próprio envelhecimento da televisão norte-americana enquanto meio de comunicação.

Evidentemente que tal explicação faz sentido em alguma instância para a parcela dos sobreviventes do Holocausto que emigraram para os Estados Unidos após a Segunda Guerra Mundial. Mas é insuficiente para justificar a recuperação de tal memória no espectro mais amplo da comunidade judaica que não vivenciou as atrocidades do período nazista. A minissérie "Holocausto" está diretamente vinculada com a emergência da memória deste evento histórico nos Estados Unidos, tendo sido considerada até como evidente marco inicial de um processo de valorização de memória que se estendeu pelos anos seguintes. As intenções discursivas deste teledrama inevitavelmente nos levam a associá-lo com um esforço não apenas de afirmação de memória, mas como um claro exemplo de evento comemorativo. Tanto em seu planejamento de produção, seu esforço de divulgação e suas escolhas narrativas, "Holocausto" explicitou de maneira clara suas intenções de memória. Cabe aqui apontar as particularidades de um tipo de memória que se define, essencialmente, como um evento comemorativo. De acordo com Allan Megill, quando a memória vem acompanhada de veneração do passado ela resulta em algo distinto, tornando-se comemoração:

Enquanto a memória é um produto de uma experiência passada, a comemoração é algo desejado no presente. A comemoração surge a partir do desejo de uma comunidade no presente de afirmar seus laços comunais fortalecendo-os por meio de uma orientação compartilhada em relação aos

${ }^{169}$ SHANDLER, op. cit., p. 156 
eventos do passado, ou, mais precisamente, por meio de uma orientação compartilhada para uma representação de eventos do passado. ${ }^{170}$

A comemoração está intrinsicamente vinculada ao dever de memória. Paul Ricouer recupera algumas características desse dever de memória que estão em conformidade com o aspecto comemorativo mencionado acima. Segundo Ricouer, há uma vinculação deste dever com a ideia de justiça, que em sua natureza é voltada para outrem: "o dever de memória é o dever de fazer justiça, pela lembrança, a um outro que não o si" ${ }^{171}$. Ricouer aprofunda sua reflexão relacionando o dever de memória à questão da dívida para com o outro: "dentre esses outros com quem estamos endividados, uma prioridade moral cabe às vítimas" $"$. Ricouer estabelece uma relação entre este dever de memória com o abuso da memória, por proclamar-se "porta-voz da demanda de justiça das vítimas" $" 173$.

É inevitável questionar quais são as intenções de quem se proclama porta-voz desta demanda de justiça em relação aos eventos traumáticos. Peter Novick rechaça a explicação do retorno do reprimido em relação à memória do Holocausto nos Estados Unidos ao apontar exatamente as preocupações que resultaram, tanto na sua anterior repressão quanto a sua recuperação e valorização. Tais preocupações estão, na visão deste historiador, bastante relacionadas com decisões conscientes que envolvem a auto percepção e a auto representação dos judeus norte-americanos. Novick recupera a noção de memória coletiva teorizada por Halbwachs para reforçar os aspectos míticos da memória e sua institucionalização no meio comunitário. Em relação à memória do Holocausto, tal institucionalização tem um papel fundamental para a iniciativa de parte da elite desta mesma comunidade de chamar a atenção para este tema. O papel da História como instância crítica tem em Peter Novick um de seus maiores defensores no que diz respeito à memória do Holocausto, como podemos observar na seguinte passagem:

Nas últimas quatro décadas, a liderança judaica americana, em resposta a uma

\footnotetext{
${ }^{170}$ MEGILL, op. cit., p. 30. (Trad. do autor). No original: 'Whereas memory is a by-product of a past experience, commemoration is something willed in the presente. Commemoration arises in the desire of a community, existing now, to affirm its communality and commonality, strengthening its bonds through a shared orientation to past events, or, more accurately, through a shared orientation to a representation of past events."

${ }^{171}$ RICOUER, op. cit. p. 101.

${ }^{172}$ Idem, p. 102.

${ }^{173}$ Ibidem.
} 
percepção de que as necessidades mudaram, escolheu destacar o Holocausto. (...). Nos anos recentes, os críticos desta escolha apontaram o que eles enxergam como uma sacralização perversa do Holocausto, e se opuseram à competição de "quem sofreu mais" como uma forma na qual os judeus agora com frequência parecem quase orgulhosos do Holocausto. Como deixei claro, estou entre esses críticos."174

Novick problematiza a presença da rememoração do Holocausto nos Estados Unidos, apontando as contradições de uma memória coletiva que se distancia dos reais conflitos e divisões da própria sociedade norte-americana e que se apega à construção de uma identidade judaica ligada ao status de vítima. O judeu como vítima fundamental é a personagem central em "Holocausto", em substituição aos discursos universalistas anteriores em que esta identidade encontrava-se diluída. Rudi é o único sobrevivente da família Weiss, e sua sobrevivência é o claro sinal da redenção vinculada ao reencontro e à afirmação de sua identidade étnica, reforçada por sua emigração ao futuro estado de Israel. Como apontamos anteriormente, a decisão de centrar a narrativa em uma família de judeus assimilados procurou aproximar estes personagens do público espectador. Esta escolha no entanto também tornou possível apresentar o judeu da diáspora (aqui especificamente identificado como o judeu norte-americano) como vulnerável ao antissemitismo. Novick também faz uma advertência para a sacralização da memória do Holocausto no país e de como, segundo sua percepção, pode ser problemático tornar essa memória apenas um emblema da identidade judaica. Sua preocupação é em relação a um discurso de memória que se tornou banal principalmente por não gerar nenhuma reflexão e não ter nenhuma relação com os conflitos políticos da própria sociedade norte-americana.

Em concordância com a abordagem crítica de Peter Novick, o historiador Wulf Kansteiner destaca que "Holocausto" de fato auxiliou países europeus com forte ligação a este evento histórico a lidar com seu passado traumático mais também inaugurou uma tradição de filmes sobre o genocídio com um certo estilo hollywoodiano que estabeleceu os Estados Unidos como a nação protagonista sobre a representação deste tema. Segundo Kansteiner, esta visão norte-americana do Holocausto diminuiu em alguma instância a percepção do país a respeito de sua responsabilidade em relação a

\footnotetext{
${ }^{174}$ NOVICK, op. cit., p. 281. (Trad. do autor). No original: "Over the last quarter century, American Jewish leadership, in response to a perception that needs had changed, has chosen to center the Holocaust (....). In recent years, critics of those leader's choices have deplored what they have seen as a perverse sacralization of the Holocaust, and objected to the competition over 'who suffered most", to the way in which Jews are now often seemed almost proud of the Holocaust. As I've made clear, I am among those critics."
} 
outros eventos históricos como o genocídio contra os indígenas, a escravidão negra e em outras tragédias mundiais vinculadas à intervenção americana na geopolítica internacional. Nas palavras de Kansteiner, "ao estimular a percepção dos conflitos em termos de extremos (nazistas versus judeus), algumas formas de rememoração do Holocausto parecem minar em vez de provocar a autorreflexão"175.

Em um artigo sobre a construção do Memorial do Holocausto em Washington, James E. Young explicita seu temor de que a memória do Holocausto nos Estados Unidos tenha se tornado um espetáculo autocongratulatório, substituindo ações reais contra o genocídio do mundo, em vez de uma inspiração para tais ações ${ }^{176}$. Adicionando mais uma observação a essas abordagens críticas, Jacob Neusner recupera uma afirmação do teólogo judeu Richard L. Rubinstein para quem "o mais apropriado memorial para as vítimas do Holocausto deveria ser um esforço nacional para um entendimento em larga escala da injustiça política e da violência" ${ }^{\prime 77}$.

Tais considerações reforçam a advertência que Allan Megill faz a respeito da indefinição entre memória e história e da anulação de seu poder crítico em relação a discursos de memória, sobretudo aqueles que procuram reforçar identidades fragmentadas em busca de coesão. Recuperemos outras abordagens críticas já anteriormente mencionadas em relação à minissérie que também apontam falhas e contradições, mas a partir de outra perspectiva que não a da crítica historiográfica propriamente dita. Como já foi apontado, Claude Lanzmann e Elie Wiesel atacam o teledrama na sua própria ideia de produção. Para ambos, tal representação é problemática e injustificável na sua origem. Ambos recuperam a tradição judaica da Bilderverbot mosaico, a proibição religiosa das imagens. É interessante constatar que Lanzmann parece seguir a avaliação preconizada por Wiesel ao abster-se da representação imagética. $\mathrm{O}$ que de fato interessa mais diretamente a esta análise é avaliar se tanto o escritor como o cineasta apontam para o que consideram uma "memória justa" a respeito do Holocausto. Tal noção de memória, se tomarmos como

\footnotetext{
${ }^{175}$ KANSTEINER, Wulf. Sold globally - remembered locally: Holocaust Cinema and the Construction of Collective Identities in Europe and the US. In: BERGER, Stefan, et alli. Narrating the Nation: Representations in History, Media and the Arts. New York: Berhan Books, 2008 p. 173. (Trad. do autor). No original: "By encouraging the perception of conflicts in terms of extremes (Nazis versus Jews) some forms of Holocaust remembrance seem to undermine rather than advance self-reflexivity." ${ }^{176}$ YOUNG, James Apud FLANZBAUM, Hilene, Memory and the Politics of Identity. IN FLANZBAUM, Hilene (Org.). The Americanization of the Holocaust. Baltimore: John Hopkins, 1999, p.82.

${ }^{177}$ NEUSNER, op. cit, p. 91. (Trad. do autor). No original: "The most appropriate American memorial to the victims of the Holocaust ought to be a national effort for the understanding of large-escale political injustice and violence."
} 
referência as críticas apontadas por eles, prescinde da representação imagética. Nela, a testemunha e o sobrevivente são os personagens principais. A interdição ao entendimento total é o seu corolário, porque tal possibilidade é vedada devido à escala do horror que envolve este evento histórico. Em ambos, a singularidade do Holocausto e o caráter sacrílego de sua representação se destacam.

Para Elie Wiesel há um dever de memória necessário, mas existem códigos para tal rememoração que, segundo o que já foi apontado, a minissérie "Holocausto" ignora. Claude Lanzmann, por outro lado rejeita a memória e a comemoração. Em suas próprias palavras:

...um filme sobre o Holocausto deve ser feito a partir do princípio de rejeição da memória, da recusa à comemoração. O pior crime artístico e moral que pode ser cometido ao se produzir uma obra dedicada ao Holocausto é considerá-lo como passado. O Holocausto pode ser um mito ou pode estar presente: em nenhum dos dois casos é memória. ${ }^{178}$

Para Lanzmann, a evocação da memória do Holocausto resultaria apenas na recuperação de "uma pálida lembrança da destruição sistemática de milhares de vidas judias" "179. Sua intenção com seu documentário "Shoah" é reconstruir os fatos por meio do testemunho percorrendo a topografia do extermínio, os personagens e os cenários dos eventos para aproximá-los o máximo possível do presente e do espectador. Nas palavras do próprio cineasta francês, recuperando uma afirmação do filósofo Emil Fackenheim, trata-se de recuperar a presença de uma ausência ${ }^{180}$. Os severos ataques de Claude Lanzmann ao teledrama apontaram seu caráter fictício e sua idealização narrativa cujo objetivo era transmitir o conhecimento a respeito de um evento cuja própria transmissão é, em sua percepção, impossível:

Tornar tal história fictícia é o mais grave tipo de transgressão: mostra os judeus entrando nas câmaras de gás, de braços dados, estoicamente, como se fossem romanos. É como Sócrates tomando cicuta. Essas são imagens idealistas que permitem todo tipo de identificação tranquilizadora. "Shoah", no entanto, é tudo menos tranquilizador. ${ }^{181}$

\footnotetext{
${ }^{178}$ LANZMANN (1981), op. cit., p. 194. No original: “... a film on the Holocaust has to set out from the principle of the rejection of memory, the refusal to comemorate. The worst moral and artistic crime that can be committed in producing a work dedicated to the Holocaust is to consider the Holocaust as past. Either the Holocaust is legend or it is present; in no case is it a memory."

${ }^{179}$ LIEBMAN, Stuart. Claude Lanzmann's, key essays. Oxford University Press, 2007, p. 9 (Trad. do autor). No original: "a pale recollection of the systematic destruction of countless Jewish lives." ${ }^{180}$ Idem, p. 33.

${ }^{181}$ Idem p. 39. No original: "Fictionalizing such a history is the most serious sort of transgression: it shows the Jews entering the gas chambers, arm in arm, stoically, as if they were Romans. It's Socrates
} 
As críticas expostas acima não anulam o fato de que a minissérie "Holocausto" de fato representou um importante evento midiático, intrinsicamente ligado à valorização da memória deste evento histórico pela própria comunidade judaica mas também como um marco inicial da institucionalização desta memória no cenário cultural norte-americano.

Um exemplo desta institucionalização foi a proposta da criação de um dia nacional em memória às vítimas do genocídio nazista, apresentada pelo senador John Danfort, que afirmou ter defendido a ideia após assistir a minissérie. Outro exemplo foi a decisão do presidente Jimmy Carter de criar uma comissão para a construção de um museu nacional em memória às vítimas do genocídio nazista em Washington ${ }^{182}$. Em 1993 foi inaugurado, no National Mall da capital dos Estados Unidos, o United States Holocaust Memorial Museum (USHMM). O museu instituiu como missão "inspirar os cidadãos e líderes em todo o mundo para enfrentar o ódio, a impedir o genocídio e promover a dignidade humana" ${ }^{\prime 183}$.

Jeffrey Shandler pontua que historiadores, críticos de cinema e cineastas consideram a minissérie não apenas um marco cultural televisivo mas "um catalisador da memória norte-americana do Holocausto" ${ }^{\text {184 }}$. Shandler destaca que o esforço de documentação dos testemunhos de sobreviventes do Holocausto em videotape foi inspirado em parte por uma reação negativa à minissérie. O projeto de documentação dos testemunhos em vídeo do Fortunoff Video Archive for Holocaust Testimonies da Universidade de Yale, por exemplo, procurou reforçar um aspecto positivo da utilização do videotape como uma resposta à utilização do Holocausto pela televisão comercial, acusação frequentemente feita em relação ao teledrama.

Judith Doneson afirma que a minissérie possibilitou a transformação do Holocausto em uma poderosa metáfora para o sofrimento universal, principalmente entre a audiência norte-americana. Neste sentido, o sofrimento dos judeus perseguidos acabou se estabelecendo como um modelo de referência para outras atrocidades do mundo contemporâneo. Populações do planeta atingidas pela guerra, refugiados,

drinking the hemlock. These are idealist images that permit all kinds of reassuring identifications. Shoah, however, is anything but reassuring."

${ }^{182}$ DONESON, op. cit., p. 190.

${ }^{183}$ Disponível em http://www.ushmm.org/information/about-the-museum. Acessado em 23 de setembro de 2014. No original: "inspires citizens and leaders worldwide to confront hatred, prevent genocide, and promote human dignity."

${ }^{184}$ SHANDLER, op. cit., p. 173. 
perseguidos políticos e outras vítimas frequentemente passaram a ser comparadas aos judeus sob o Terceiro Reich. Doneson não nega que a minissérie apresenta o Holocausto a partir de uma perspectiva essencialmente judaica e que sua narrativa está imbuída de uma perspectiva sionista mas, segundo ela, este evento judaico é "paradigmático para todos os homens" ${ }^{\prime 185}$. Em sua concepção, o teledrama não banalizou o Holocausto mas o popularizou de maneira a disponibilizar sua mensagem em uma amplitude até então inédita.

A historiadora Alison Landsberg concorda com Judith Doneson nessa questão, posicionando-se contra a abordagem crítica de Peter Novick, para quem a emergência da memória do Holocausto nos Estados Unidos está unicamente ligada à uma decisão política das elites judaicas americanas que procurou tanto dar suporte ao Estado de Israel como estabelecer uma identidade judaica distinta ancorada na experiência histórica traumática. Landsberg não menciona diretamente o impacto do teledrama nos Estados Unidos, mas pontua que a valorização da memória do Holocausto e o desenvolvimento de um discurso popular a respeito do preconceito e do antissemitismo não constitui uma evasão mas, ao contrário, permite um reconhecimento dos crimes pelos quais os Estados Unidos têm responsabilidade direta ${ }^{186}$. Landsberg menciona a minissérie "Holocausto" ao estabelecer uma analogia entre o impacto produzido pela exibição do teledrama na antiga Alemanha Ocidental e a exibição de "Raízes" nos Estados Unidos. Enquanto "Raízes" engendrou um debate público sobre o tabu dos séculos de escravidão nos Estados Unidos, "Holocausto" foi o ponto de partida para a discussão de um tema de inegável relevância história e social para a Alemanha: o Terceiro Reich e a Solução Final. A discussão pública de tais temas ocorreria novamente na Alemanha reunificada quando da exibição do filme "A Lista de Schindler", do diretor Steven Spielberg, em 1994. Landsberg reforça que tanto a minissérie quanto o filme provocaram discussões sobre valor pedagógico do afeto, da identificação do público e da subjetividade nas formas de fixação da memória sobre eventos históricos.

Mirian Hansen faz uma afirmação pertinente referente à frequência da utilização dos veículos de mídia e de consumo cultural de massa em relação à memória do Holocausto. O extermínio contra os judeus perpetrado pelo nazismo esforçou-se no objetivo de não deixar para a posteridade uma comunidade de sobreviventes, como viúvas e órfãos, por exemplo. Até mesmo os locais de sepultamento foram eliminados,

${ }^{185}$ DONESON, op. cit. p. 195.

${ }^{186}$ LANDSBERG, op. cit. p. 115. 
já que a ideologia nazista pretendia apagar a presença da própria memória judaica de seus domínios. Por conta disso, a memória do Holocausto sempre foi mais dependente da mediação midiática ${ }^{187}$. Hansen também considera que as críticas à americanização do Holocausto que levam em conta apenas o seu caráter ideológico podem ignorar outros aspectos relevantes que dizem respeito a frequência da representação do Holocausto na cultura visual norte-americana. Segundo esta autora, tal fixação pode ser lida "como parte de um discurso americano de modernidade no qual a República de Weimar e a Alemanha nazista funcionam como símbolos de uma modernidade que falhou" ${ }^{\prime 88}$. Esta fixação, neste sentido, pode ser lida como a projeção desta catástrofe da modernidade em uma realidade histórica distinta e na derrota de outra nação, preservando assim a própria noção americana de modernidade ${ }^{189}$.

Aprofundando esta questão da identificação do público com uma obra audiovisual de claras conotações pedagógicas que busca reforçar determinado discurso de memória, chega-se ao ponto em que a própria recepção do público cria novos significados e resultados na sua apropriação de tal discurso, principalmente em um meio de alcance tão amplo como a televisão. Tal apropriação pode oferecer ao historiador e à própria disciplina histórica uma importante contribuição como exemplo de enfrentamento do passado e para um maior entendimento de questões historiográficas suprimidas do debate público. Faz-se referência aqui, obviamente, à exibição de "Holocausto" na Alemanha Ocidental e à repercussão e as discussões que o teledrama gerou na esfera pública. É importante destacar, no entanto, quais são os fatores que possibilitaram que uma produção audiovisual da televisão norte-americana pudesse se estabelecer como um divisor de águas na memória pública alemã a respeito do enfrentamento do passado nazista.

O especialista em teoria literária Andreas Huyssen apresentou uma justificativa pertinente a esse respeito, que permite também estabelecer um diálogo com as relações entre as prerrogativas da objetividade da História e os aspectos de subjetividade dos discursos de memória. Huyssen recupera o tremendo impacto social e emocional produzido pelo teledrama, que mesmo alvo de pesadas críticas, tanto nos discursos da direita quanto da esquerda, auxiliou os alemães a enfrentar o passado nazista, quase suprimido dos discursos oficiais e públicos. As críticas em geral advertiam para a

\footnotetext{
${ }^{187}$ HANSEN, op. cit., p. 310.

${ }^{188}$ Idem, p. 311. No original: "as part of an American discourse on modernity in which Weimar and Nazi Germany figure as an allegory of a modernity gone wrong."

${ }^{189}$ Idem.
} 
impossibilidade, apontada por todos, da compreensão racional do antissemitismo alemão por meio de um produto cultural de massa com escancarado estilo melodramático. Huyssen destaca o medo da esquerda alemã, para quem a emoção e a subjetividade eram parte de um legado suspeito do Terceiro Reich: "Precisamente porque Hitler foi bem sucedido ao explorar a emoção, os instintos e o "irracional", todo este âmbito tornou-se profundamente suspeito para as gerações do pós-guerra"190. Huyssen lembra que "Holocausto" não teve como proposta fornecer um conhecimento total do antissemitismo alemão e do Nazismo:

\begin{abstract}
A questão-chave que deve ser enfrentada à luz do sucesso de "Holocausto" na Alemanha é precisamente verificar por que esta minissérie possibilitou a abertura para uma compreensão a respeito do Holocausto que os discursos racionais, acadêmicos e objetivos e as representações das décadas passadas falharam em produzir. ${ }^{191}$
\end{abstract}

A análise de Andreas Huyssen está centrada na abordagem estética, mas levanta importantes questionamentos sobre o papel das produções culturais de massa na educação política, ultrapassando a dicotomia entre documentários de vanguarda e narrativas audiovisuais de apelo popular. Sem fazer uma defesa cega do teledrama como um instrumento legítimo de superação das "aporias da vanguarda" 192 , Huyssen procura demonstrar que a simples justificativa de produtos culturais televisivos como instrumentos de manipulação e dominação não são suficientes para explicar a deficiência destas mesmas produções audiovisuais. Neste caso específico o autor se refere à indisponibilidade do enfrentamento do passado pela sociedade alemã, a repressão do chamado Vergangenheitsbewältigung, de alguma forma superada quando da exibição da minissérie "Holocausto" na televisão da República Federal Alemã. Huyssen define o significado do Vergangenheitsbewältigung na Alemanha do pósguerra:

como o processo psíquico de lembrança, repetição e perlaboração, processo este que deve começar no nível individual mas que só pode ser concluído com

\footnotetext{
190 HUYSSEN, Andreas. The politics of identification: "Holocaust" and West German drama. New German Critique, n. 19, Special Issue 1: german and jews, 1980, p. 118. (Trad. do autor). No original: "Precisely because Hitler was successful in exploiting emotions, instincts and the 'irrational', this whole sphere has in turn become deeply suspect to post-war generations."

${ }^{191}$ Idem, p. 118. No original: "the key question which must be faced in the light of 'Holocaust's' success in Germany is precisely why this series has opened up an understanding of the Holocaust which all the enlightened, rational, and objective discourses and representations of the past decades failed to produce." 192 Idem, p. 119.
} 
êxito se tiver o suporte do coletivo, da sociedade como um todo. O cinema, a mídia e as instituições educacionais poderiam ter ajudado a criar um clima favorável para um Vergangenheitsbewältigung coletivo se de fato o confronto com esse passado tivesse tido alguma prioridade social e política na Alemanha. ${ }^{193}$

$\mathrm{O}$ autor procura responder por que as tentativas anteriores no campo da dramaturgia falharam em despertar ou fomentar uma discussão relevante sobre o enfrentamento do passado nazista na sociedade alemã, algo que a teledramaturgia de "Holocausto" foi capaz de fazer. A tese de Huyssen é a de que as formas abstratas utilizadas pelos formatos da estética dramatúrgica do pós-guerra, marcadas sobretudo pela parábola brechtiana, impediam uma identificação emocional do público com os personagens. Tal abordagem dramatúrgica procurou apontar as feridas do nazismo e certa continuidade entre este e a República Federativa Alemã, mas "impediu a identificação do público com a especificidade histórica do sofrimento dos judeus durante o Terceiro Reich" ${ }^{\text {"194 }}$. Huyssen também aponta que os judeus representados em algumas obras da dramaturgia a abordarem o período nazista estavam identificados na posição do "outro". A apresentação marginal dos personagens judeus os afastou da identificação do público e estabeleceu uma identificação entre estes e os perpetradores nazistas, o que explica parcialmente a negação e o afastamento que resultava do sentimento de culpa.

Para Andreas Huyssen, a identificação do público alemão com a história de uma família foi o grande facilitador para o sucesso e o impacto de "Holocausto". Tal identificação só foi possível porque a família Weiss é apresentada, essencialmente, como uma família de judeus assimilados, quase que completamente integrados à cultura alemã. Huyssen aponta, no entanto, que não foi apenas a estratégia narrativa do teledrama que permitiu tal identificação. O próprio meio televisivo contribuiu de maneira significativa para um contexto receptivo diferente do cinema e do teatro. $\mathrm{O}$ ato de assistir à minissérie na esfera privada no espaço doméstico, familiar por natureza, potencializou este processo de identificação com as vítimas judias, ultrapassando este espaço para configurar-se em um debate em nível nacional durante os dias de exibição. A catarse coletiva produzida por "Holocausto", na visão de Huyssen, revelou a

\footnotetext{
${ }^{193}$ Idem, p. 120. No original: "as the psychic process of remembering, repeating, and working through, a process which has to begin in the individual, but which can only be succesfully completed if it is supported by the collective, by society at large. The theater, the media and educational institutions all could have helped create a climate favorable to a collective Vergangenheitsbewältigung if indeed a confrontation with the past had been given social and political priority in Germany."

${ }^{194}$ Idem, p. 124. No original: "prevented audience identification with the historic specificity of Jewish suffering during the Third Reich."
} 
necessidade que a sociedade alemã tinha de identificação com as vítimas de maneira a se liberar dos mecanismos de negação e supressão do passado nazista.

É interessante cotejarmos as proposições de Andreas Huyssen com as críticas já anteriormente apresentadas sobre o teledrama, sobretudo em relação à pertinência da representação do Holocausto na mídia televisiva comercial, sua alegada banalização e a apresentação da família Weiss como judeus assimilados. Foi justamente o enredo melodramático de uma narrativa familiar próximo ao formato de uma telenovela criticado por Elie Wiesel que possibilitou que a sociedade alemã, em um alcance público inédito, confrontasse seu passado de responsabilidade em relação aos crimes do nazismo. As abstrações da representação do Holocausto e do nazismo que precederam o teledrama, em suas prerrogativas de reflexão e objetividade que negavam uma identificação emocional, não foram eficazes em relação a um enfrentamento do passado. Em paralelo, a caracterização dos personagens do teledrama como judeus assimilados, que na visão crítica de Claude Lanzmann procurou atenuar o caráter judaico das vítimas, foi um componente essencial de identificação dos telespectadores alemães com a família Weiss, posicionando-os pela primeira vez ao lado dessas mesmas vítimas.

O efeito de "Holocausto" na Alemanha ganha um maior significado se lembrarmos que tais resultados de identificação e enfrentamento do passado da sociedade alemã não foram intencionalmente pensados para a minissérie em sua produção. Como apontamos anteriormente, o teledrama construiu uma narrativa fortemente vinculada a um discurso de memória e identidade em relação a comunidade judaica (de modo mais específico aos judeus norte-americanos, mas que pode-se aplicar à comunidade judaica como um todo). $\mathrm{O}$ que se verificou foi o resultado espontâneo de um produto cultural que, ao ser exibido em outro contexto, engendrou novos significados. O luto coletivo do Vergangenheitsbewältigung fomentado pela exibição de "Holocausto" marcou o início de um questionamento a respeito do passado do nazismo, do Holocausto da identidade problemática da sociedade alemã diante deste passado que engendrou, alguns anos mais tarde a chamada Historikertreit ${ }^{195}$, ou Querela dos Historiadores alemães. A resposta da minissérie alemã "Heimat" a Holocausto também

\footnotetext{
${ }^{195}$ A Historikerstreit, ou Querela dos historiadores alemães, foi um debate provocado pela publicação, em 1986, de um artigo do historiador Ernst Nolte no jornal Frankfurter Allgemeine Zeitung, seguido da publicação de dois artigos, em resposta às proposições de Nolte, do filósofo Jürgen Habermas no jornal Die Zeit. O debate caracterizou-se por uma disputa entre intelectuais de direita e de esquerda a respeito do caráter único dos crimes nazistas ou de sua comparabilidade em relação a outras atrocidades nacionais, como os crimes do Stalinismo, por exemplo. Ver LA CAPRA, Dominick. Representing the Holocaust: Reflections on the Historians' Debate. In: FRIEDLÄNDER (1992), op. cit., p. 108.
} 
está inserida neste contexto de acerto de contas com o passado, relacionado no entanto com a reivindicação da recuperação de uma identidade que não problematiza a questão do nazismo e do Terceiro Reich

Os argumentos de Andreas Huyssen nos permitem estabelecer uma relação com as tensões entre a História e a memória, destacando o compromisso de objetividade crítica da primeira e as inesperadas contribuições do caráter subjetivo da segunda para o entendimento do passado. Tal exemplo parece fazer ultrapassar a dicotomia entre intenções discursivas de memória afirmativa ligadas à comemoração e abordagens críticas que procuram desnudar tais discursos em busca da objetividade e da autenticidade. Apenas uma abordagem mais aprofundada sobre a produção e a recepção de determinados produtos culturais (no caso específico, a minissérie que é o objeto desta investigação), é capaz de oferecer uma novo olhar sobre tais tensões, que em sua natureza são insolúveis, mas que parecem oferecer mais uma porta aberta ao diálogo do que necessariamente um conflito de posições. 


\section{CONSIDERAÇÕES FINAIS}

A preocupação com a memória verificada na contemporaneidade é frequentemente atacada por um alegado excesso. No que concerne à memória coletiva do Holocausto, especificamente, este excesso é apontado por alguns críticos tanto como uma fixação resultante de decisões políticas em relação à recuperação narrativa de um passado traumático - que resulta em uma cultura de competição entre grupos sociais pelo status de vítima ${ }^{196}$ - quanto por um processo de banalização e transformação deste evento histórico traumático em uma "mercadoria" da indústria cultural. Aqui, os abusos de memória também se configuram como abusos do esquecimento. Paul Ricoeur afirma que, como mediadora da memória, a narrativa coloca em ação a sua natureza seletiva: "a ideologização da memória é possibilitada pelos recursos de variação que o trabalho de configuração narrativa oferece" ${ }^{" 197}$. Ricoeur destaca as práticas da recordação ligadas à questão da memória manipulada e do cruzamento desta com a questão da identidade além de apontar a importância da representação fílmica na configuração de uma narrativa, e consequentemente, de um discurso de memória dominante.

A minissérie "Holocausto" é frequentemente apontada como um marco do início dessa valorização da memória e um disparador daquilo que o historiador Saul Friedländer apontou como um certo fascínio contemporâneo com a representação do fascismo no cinema e na ficção e um discurso político de vitimização sem qualquer relação com a tragédia da Shoah. Como afirma Andreas Huyssen, há uma proliferação da exploração do trauma reencenado por meio de representações literárias e cinematográficas do Holocausto que podem gerar um resultado ofensivo ${ }^{198}$. Huyssen conclui que a resposta à alegada banalização representada por um teledrama como "Holocausto" na construção de museus e de monumentos públicos que celebram um tipo de "memória justa" deste evento acaba por repetir uma memória formada por imagens e discursos meramente ritualísticos. Recuperamos aqui as críticas apontadas pelo historiador Peter Novick em relação a uma "memória fora do lugar" exemplificada

\footnotetext{
${ }^{196}$ MAIER, Charles S. The Unmasterable ast: History, Holocaust and german national identity APUD LEVY, op. cit., p. 33.

${ }^{197}$ RICOEUR, op. cit.,. p. 455.

${ }^{198}$ HUYSSEN, Andreas. Twilight memory: marking time in a culture of amnesia. New York: Routledge, 1995 , p. 256.
} 
pela proeminente fixação da cultura americana com o Holocausto. Como mencionado anteriormente, tal fascinação com o tema é desnudada por Novick para quem o surgimento de tal fixação está diretamente relacionado a uma agenda política e ideológica específica e com intenções bem definidas. Novick não duvida que produções audiovisuais como a minissérie "Holocausto" ou o filme "A Lista de Schindler" provoquem apropriadas reações emocionais de dor e luto em relação ao genocídio dos judeus europeus. Tais reações no entanto, segundo este historiador "não resolvem a questão do por que extrair tal resposta emocional dos americanos é visto como uma tarefa tão urgentemente importante",199

A análise da minissérie "Holocausto" apresentada nesta investigação reafirma a abordagem crítica apontada pelo historiador Peter Novick ao revelar a presença destacada de um discurso de afirmação de identidade neste documento audiovisual. Ao apresentarmos a trajetória da representação do Holocausto na cultura audiovisual norteamericana, o apoio de instituições judaicas na produção do teledrama e seus elementos narrativos e de veiculação midiática procuramos reforçar a presença de um determinado discurso. Este discurso se caracteriza pelo protagonismo judaico em relação a este evento histórico e sua importância central enquanto vítima histórica deste evento. O discurso narrativo da minissérie destaca a importância do heroísmo e da resistência como elementos fundamentais de afirmação étnica, a despeito do horror e da brutalidade do extermínio. Em "Holocausto" uma alegada passividade judaica sob a barbárie do Terceiro Reich dá lugar a um esforço comunitário de resistência que caminha para um final redentor. Os combatentes do Gueto de Varsóvia não sobrevivem à implacável máquina nazista, mas sua bandeira sionista desfraldada nos escombros será hasteada na futura pátria judaica em Israel. A história da família Weiss é a narrativa que simboliza percurso de reencontro do judeu da diáspora com sua identidade negligenciada na assimilação.

O discurso político de afirmação étnica presente em "Holocausto" configura a minissérie como um ato comemorativo para o qual a comunidade judaica (e mais diretamente o judeu da diáspora) é chamada a compartilhar. Ao enfatizar a importância do olhar crítico de Peter Novick sobre a recuperação desta memória, esta análise também procurou reforçar o papel crítico do conhecimento histórico em relação aos discursos de memória. $\mathrm{O}$ historiador Allan Megill afirma que cabe à pesquisa histórica

\footnotetext{
${ }^{199}$ NOVICK, op. cit. p. 214. No original: “...leaves unresolved the question of why the eliciting of these responses from Americans is seen as so urgently importante as task."
} 
problematizar os discursos de memória porque tal abordagem crítica só pode "vir de fora" ${ }^{200}$. Ao destacar os discursos de memória acionados por preocupações políticas do presente, o historiador exercita o estimulante papel da pesquisa histórica de revelar o inusitado e o desconhecido, desconstruir as intenções discursivas e fomentar a necessária reflexão crítica em relação às representações do passado.

Ciente da importância do papel crítico da História apresentado acima, retomo a questão das relações entre essa e a memória. Se considerarmos as críticas historiográficas de maneira absoluta, negligenciando as contribuições que um discurso audiovisual de memória pode oferecer para o enfrentamento do passado, corremos o risco de não avançarmos em relação a aspectos importantes também para a disciplina histórica. Os efeitos produzidos por "Holocausto" em sua exibição na Alemanha reforçam a importância de se levar em conta os aspectos subjetivos da memória, principalmente porque as tentativas de historicizar o passado nazista de maneira objetiva falharam neste ambiente. Retomemos novamente as reflexões de Andreas Huyssen a esse respeito:

Se é nossa preocupação e responsabilidade evitar o esquecimento, devemos estar abertos aos poderosos efeitos que um teledrama melodramático pode exercer na mente dos telespectadores atualmente. As gerações pós-Holocausto que receberam sua socialização inicial com este tema através da televisão podem encontrar o caminho para os testemunhos, os documentários ou a pesquisa histórica exatamente por meio do Holocausto ficcional e emocional produzido para o horário nobre da televisão. ${ }^{201}$

Huyssen afirma que o Holocausto está fraturado em diferentes modos de memorialização, em distintos lugares e situações. A obsessão na impossibilidade de sua representação, transmissão e na incomparabilidade deste evento histórico (recuperando as críticas feitas por Elie Wiesel e Claude Lanzmann), embora procurem preservar alguns aspectos éticos em relação à esta memória, tem pouco efeito em um contexto no qual a popularização do Holocausto é cada vez mais ampliada e se multiplica em diferentes meios e suportes.

Considero que mesmo os produtos culturais de comunicação de massa, como a minissérie aqui analisada, marcados por um discurso de memória com claras intenções

\footnotetext{
${ }^{200}$ MEGILL, op. cit., p. 28.

${ }^{201}$ HUYSSEN (1995), op. cit., p. 256. No original: "For it is our concern and responsability to prevent forgetting, we have to be open to the powerful effects that a melodramatic soap opera can exert on the minds of viewers today. The post-Holocaust generations that received their primary socialization through television may find their way toward testimony, documentary, and historical treatise precisely via a fictionalized and emotionalized Holocaust made for prime time television."
} 
políticas de afirmação comunitária e etnicidade, podem oferecer insights indispensáveis para o conhecimento histórico exatamente por seu caráter subjetivo. Foi a identificação dos alemães com as vítimas judias do teledrama que os despertou em relação ao passado nazista e à ausência dos mesmos judeus em sua sociedade. As investigações da disciplina histórica a respeito dessa ausência foram disparadas exatamente pelas emoções de um discurso de memória apresentado na televisão. 


\section{REFERÊNCIAS BIBLIOGRÁFICAS}

ADORNO, Theodor. Educação após Auschwitz". In :Educação e Emancipação. $3^{\mathrm{a}}$ Ed. São Paulo: Paz e Terra, 2003.

ALLEN, Robert C. (Org.) Channels of discourse, reassembled: television and contemporary criticism. North Carolina: The University of North Carolina Press, 1992.

ANDERSON, Benedict. Comunidades imaginadas: reflexões sobre a origem e a difusão do nacionalismo. São Paulo: Companhia da Letras, 2008.

ARENDT, Hannah. Eichmann em Jerusalém: um relato sobre a banalidade do mal. São Paulo: Companhia das Letras, 1999, p. 41.

BARON, Lawrence. Projecting the Holocaust into the Present. Maryland: Rowman \& Littlefield Publishers, 2005.

BRINK, Cornelia. Secular icons: looking at the photographs from nazi concentration camps. History \& Memory. Indiana University Press, Vol. 12, n. 1, pp. 135-150, 2000.

BROOKS, Peter. The melodramatic imagination: Balzac, Henry James, melodrama and the mode of excess. New Haven: Yale Universty Press, 1995.

BROWNING, Jim. French display tolerance to "Holocaust" but watch. The Christian Science Monitor. Massachusetts, 15 fev. 1979.

BERGER, Stefan, et alli. Narrating the Nation: representations in History, media and the arts. New York: Berhan Books, 2008 p. 173.

CAPELATO, Maria Helena (Org.). História e cinema. São Paulo: Alameda, 2007.

CITRINOWICZ, Roney. Memória da barbárie: a história do genocídio dos judeus na Segunda Guerra Mundial. São Paulo: Edusp, 1990.

CREEBER, Glen. Taking our personal lives seriously: intimacy, continuity and memory in the television drama serial. Media Culture Society. Sage Publications, n. 23, 2001.

DE VITO, John, TOPEA, Frank. Epic television miniseries: a critical history. North Carolina: MacFarland \& Company, 2010.

DER SPIEGEL, 29 Jan 1979, p. 18.

DONESON, Judith E.. The Holocaust in American film. Syracuse: Syracuse University Press, 2002, p. 82.

EDGERTON, Gary. R. COLLINS, Peter C. (Org). Television histories: shaping 
collective memory in the media age. Kentucky University Press, 2001.

ENCICLOPEDIA JUDAICA. Rio de Janeiro: Editora Tradição, 1967.

FEINGOLD, Henry. Four days In April: a review of NBC's dramatization of the Holocaust. Shoah: a review of Holocaust Studies and Commemorations. Vol. 1, n. 1, 1978.

FLANZBAUM, Hilene (Org.). The Americanization of the Holocaust. Baltimore: John Hopkins, 1999.

FRIEDLÄNDER, Saul. A Alemanha nazista e os judeus: Vol. I, os anos da perseguição, 1933-1939. São Paulo: Perspectiva, 2012.

A Alemanha nazista e os judeus: Vol. II, os anos de extermínio, 1939-1945. São Paulo: Perspectiva, 2012.

Probing the limits of representation: Nazism and the "final solution" (Org.) Cambridge, Mass.: Harvard University Press, 1992.

GOLDHAGEN, Daniel Jonah. Os carrascos voluntários de Hitler: o povo alemão e o Holocausto. São Paulo, Companhia das Letras, 1997.

GUTMAN, Ysrael. The Jews of Warsaw. 1939-1943: ghetto, underground, revolt. Indiana: Indiana University Press, 1989.

HAGGITH, Toby. Filming the liberation of Bergen-Belsen, in Holocaust and the moving image: representations in film and television since 1933. London: Wallflower Press, 2005.

HANSEN, Miriam. Schindler's List is not Shoah: the second commandment, popular modernism and public memory. Critical Inquiry, Chicago: Chicago University Press, vol. 22, n. 2, 1996, p. 292-312.

HAUSER, Arnold. História social da arte e da literatura. São Paulo, Martins Fontes, 1995.

HILBERG, Raul. The destruction of the European Jews. New Jersey: Holmes y Meier, 1985.

HOWARD, John. ROTHBART, George. SLOAN, Lee. The response to "Roots": a national survey. Journal of Broadcasting. vol. 22, n. 33, 1978, p. 279-286.

HUYSSEN, Andreas. The Politics of Identification: "Holocaust" and West German Drama. New German Critique. Duke University Press, Edição Especial 1: Germans and Jews, n. 19, p. II, p. 117-136.

Present pasts: media, politics, amnesia. Public Culture, Durham:

Duke University Press, v.12, n. 1, p. 21-38. 
York: Routledge, 1995

Twilight memory: marking time in a culture of amnesia. New

INSDORF, Annete. Indelible Shadows: Film and the Holocaust. New York: Cambridge University Press, 2003.

JACOBSON, Matthew Frye. Roots Too: White ethnic revival in post-civil rights America. Cambridge: Harvard University Press, 2006.

JEWISH FRONTIER. New York, Abr. 1979. p. 4.

JOYCE, Robins, OLICK, Jeffrey K,. Social memory studies: from "collective memory" to the historical sociology of mnemonic practices. Annual review of sociology. Vol. 24 (1998), pp 105-140.

KANSTEINER, Wulf. Sold Globally - Remembered Locally: Holocaust Cinema and the Construction of Collective Indentities in Europe and the US. IN Stefan Berger, et al. Narrating the Nation: Representations in History, Media and the Arts. New York: Berhan Books, 2008.

KARNAL, Leandro et. al. História dos Estados Unidos: das origens ao século XXI. São Paulo: Contexto, 2007.

KORNIS, Mônica Almeida. Cinema, Televisão e História. Rio de Janeiro: Jorge Zahar, 2008.

KUGELMASS, Jack. Key texts in american jewish culture. New Jersy: Rutgers University Press, 2003.

LANDSBERG, Alisson. Prosthetic memory: the transformation of American remembrance in the age of mass culture. New York: Columbia University Press, 2004

LANZMANN, Claude. From the Holocaust to "Holocaust", Dissent Magazine, New York, vol. 1, n. 2, 1981, p. 188-194.

LEVY, Daniel, OLICK, Jeffrey K.,VINITZKY-SEROUSSI, Vered. The Collective memory reader. Oxford: Oxford University Press, 2011.

LIEBMAN, Stuart. Claude Lanzmann's, key essays. Oxford University Press, 2007

LIPSTADT, Debora E.. America and the Memory of the Holocaust. 1950-1965. Modern Judaism, Oxford University Press, vol. 16, n. 3, p. 195-214.

MAGID, Shaul. "The Holocaust and Jewish identity in America: Memory, the unique, and the universal," Jewish Social Studies: History, Culture, Society. Indiana University Press, vol. 18, n. 2, 2012, 100-135.

MARCONDES FILHO, Ciro (Org.). Dieter Prokop. São Paulo: Ática, 1986

MEGILL, Allan. Historical knowledge, historical error. Chicaco: Chicago University 
Press, 2007.

MINTZ, Alan. Popular culture and the shaping of Holocaust memory in America. Seattle: University of Washington Press, 2001.

MORETTIN, Eduardo. "Ver o que aconteceu": Cinema e História em Griffith e Spielberg. Revista Galáxia, São Paulo, n. 22, dez. 2011, p. 196-207.

NEUSNER, Jacob. Strangers at home: 'The Holocaust', zionism and American judaism. Chicago: University of Chicago Press, 1981.

NORA, P. Entre memória e história: a problemática dos lugares. Tradução de Yara Aun Khoury. Revista do Programa de Estudos Pós-Graduados em História e do Departamento de História da PUC-SP. (Projeto História: História e Cultura). São Paulo, n.10, dez.1993.

NOVICK, Peter. The Holocaust and collective memory. London: Bloomsbury, 2000

O'CONNOR, John. NBC Holocaust's, Art versus Mammon. The New York Times. New York, 20 de Abril de 1978.

PINSKY, Carla Bassanezi. (org). Fontes Históricas. São Paulo: Contexto, 2005

RICOUER, Paul. A Memória, a História, o Esquecimento. Campinas: Editora da Unicamp, 2007.

ROSENSTONE. Robert. A. A História nos filmes, os filmes na História. São Paulo: Paz e Terra. 2010.

ROSENTHAL, Alan (Org). Why docudrama? Fact-Fiction on film and TV. Illinois: Southern Illinois University Press, 1999

SÁNCHEZ-BIOSCA, Vicente. Cine de história, cine de memória: la representación y sus limites. Madrid: Ediciones Cátedra, 2006.

SELIGMAN-SILVA, Márcio(org.). História, memória, literatura. Campinas: Editora da Unicamp, 2003.

SHANDLER, Jeffrey. While America watches: televising the Holocaust. New York: Oxford University Press, 1999.

SOBCHACK, Vivian (Org.) The persistence of History: cinema, television and the modern event. New York : Routledge, 1996.

SUNDQUIST, Eric J.. Strangers in the land: blacks, jews, post-Holocaust America. Cambridge: Harvard Universty Press, 2005.

TANENBAUM, Marc. H. Avaliação de roteiro da minissérie "Holocausto", 25 de Julho de 1977. Ao vice-presidente da NBC, Robert Kasmire. The Jacob Rader marcus Center of the American Jewish Archives, caixa 6, pasta 2, série E, arquivo geral alfabético, 
1960-1992.

THE AMERICAN JEWISH COMMITTEE. Americans confront the Holocaust: a study of reactions to NBC-TV's four-part drama on the nazi era. New York, 1978, relatório.

THE GERMAN TRIBUNE, 4 de Fevereiro de 1979, número 875, p. 4.

THE ISRAEL DIGEST. Jerusalém, 29 set. 2009.

THE RECORD: The Holocaust in History, 1978.

TIME MAGAZINE, New York, 5 fev. 1979.

VAST French TV audience sees start of "Holocaust". The New York Times, New York, 15 fev. 1979.

VIDAL-NAQUET, Pierre. Os assassinos da memória: o revisionismo na história. São Paulo: Papirus, 1988.

WIESEL, Elie. Trivializing the Holocaust: semi-fact and semi-fiction. The New York Times. New York, 16 de abril de 1978. 1-29.

WYTMAN, David. The abandonment of the Jews: America and the Holocaust, 19411945. New York: Panthon Books, 1984.

XAVIER, Ismail. $O$ discurso cinematográfico: a opacidade, a transparência. São Paulo: Paz de Terra, 2008.

XAVIER, Ismail. O olhar e a cena. São Paulo: Cosac \& Naify, 2003.

YOUNG, James E. America's Holocaust. Memory and the Politics of Identity. IN Hilene Flanzbaum (org). The Americanization of the Holocaust. Baltimore: John Hopkins, 1999.

\section{FILMOGRAFIA}

HOLOCAUSTO. Direção: Marvin J. Chomsky. Roteiro de Gerald Green. Intérpretes: James Woods, Meryl Streep, Rosemary Harris, Joseph Bottoms, entre outros. São Paulo: Versátil Home Vídeo, 2012, 3 DVDs (449 min.), sonoro, digital. Legendado. Ingles/Português. 
JULGAMENTO DE NUREMBERG. Direção: Anthony Mann. Interpretes: Spencer Tracy, Burt Lancaster, Richard Widmark, Maximilian Schell, entre outros. São Paulo: Silver Screen Distribuidora, 1 DVD (187 min.), sonoro, digital. Legendado. Inglês/Espanhol/Português.

O DIÁRIO DE ANNE FRANK. Direção: George Stevens. Interpretes: Shelly Winters, Daine Baer, Millie Perkins, entre outros. São Paulo: Fox Home Entertainment, 1 DVD (171 min.), sonoro, digital. Legendado. Inglês/Espanhol/Português.

O HOMEM DO PREGO. Direção: Sidney Lummet. Intérpretes: Rod Steiger, Geraldine Fitzgerald, Brock Peters, Jaime Sánchez, entre outros. Manaus: Cult Classic DVD, 1 DVD (114 min.), sonoro, digital. Legendado. Inglês/Português.

ROOTS. Direção: Marvin J. Chomsky. Intérpretes: John Amos, Ben Vereen, LeVar Burton, Louis Gossett, Jr. entre outros. Estados Unidos: Warner Bros. Entertainment, 2011, 7 DVDs (573 min), sonoro, digital. Legendado. Inglês/Francês/Espanhol.

SHOAH (Shoah). Direção: Claude Lanzmann. São Paulo: Instituto Moreira Sales 4 DVDs (543 min), sonoro, digital. Legendado. Português. Idiomas falados em Francês, Polônes, Alemão, Hebraico, lídiche, Inglês. 